\title{
A efetivação dos direitos humanos: o desafio do direito no atendimento interdisciplinar a vítimas de violência
}

\author{
Dissertação de Mestrado \\ Área de concentração: Direitos Humanos
}

Orientadora Profa. Dra. Flávia Inês Schilling

\author{
Faculdade de Direito \\ Universidade de São Paulo \\ São Paulo \\ 2009
}




\section{A efetivação dos direitos humanos: \\ o desafio do direito no atendimento \\ interdisciplinar a vítimas de violência}

Dissertação apresentada à Banca Examinadora da Faculdade de Direito da Universidade de São Paulo, como exigência parcial para obtenção do título de MESTRE em Direito, área de concentração em Direitos Humanos, sob orientação da Profa. Dra. Flávia Inês Schilling.

São Paulo

2009 
Akemi Kamimura

A efetivação dos direitos humanos: o desafio do direito no atendimento interdisciplinar a vítimas de violência

Dissertação apresentada à Faculdade de Direito da Universidade de São Paulo, como exigência parcial para obtenção do título de MESTRE.

Área de concentração: Direitos Humanos Orientação: Profa. Dra. Flávia Inês Schilling.

Banca Examinadora 
Para todos aqueles que se dedicam ao atendimento às vítimas de violência e ao exercício cotidiano dos direitos humanos 


\section{AGRADECIMENTOS}

A meu pai, Massayoshi Kamimura, pelo cuidado e limite ensinados com paciência e respeito.

À minha mãe, Mitsuyo Kamimura, pelo suporte com amor e carinho, sempre.

A minhas queridas irmãs, Mayumi, Massumi e Tiyomi, pela convivência e aprendizado conjuntos.

Aos sobrinhos, Camila e Daniel, pela singela alegria das descobertas e pela simplicidade do olhar.

À minha orientadora, Profa. Dra. Flávia Inês Schilling, pelo respeito, paciência e dedicação durante minha trajetória nesse mestrado; pelo belo exemplo de professora e de pessoa; pelo compromisso com o exercício docente e com os direitos humanos.

À querida profa. Dra. Flávia Piovesan, pela amizade e oportunidade ímpar de aprender, pesquisar e ensinar os direitos humanos, dentro e fora da sala de aula.

Às preciosas amigas, Fernanda Castro Fernandes de Oliveira, Júlia Mello Neiva, Camila Akemi Perruso, Estela Waksberg Guerrini e Carolina Martins Marinho, pela amizade, pelos sonhos e experiências compartilhados e pela valiosa companhia no caminhar pela prática dos direitos humanos.

Aos queridos colegas da primeira turma de mestrado em direitos humanos da Faculdade de Direito da USP, especialmente a Stella Camlot Reicher, Juliana Novaes Mancuso, Juliana de Moura Gomes e Luisa Helena Oliveira Marques, pelo companheirismo durante os tensos períodos da vida acadêmica e pelas trocas e sugestões tão importantes para o amadurecimento e confiança na produção.

A todos os profissionais que lidam diariamente com as vítimas de violência, especialmente às equipes do CNRVV e do CRAVI pela fundamental colaboração na pesquisa de campo.

Aos advogados militantes de direitos humanos, que cotidianamente nadam contra a maré com fôlego e compromisso.

Ao querido Alexandre de Paula Silva, pela companhia nas madrugadas de escrita e por nosso amor, precioso para o meu viver. 


\section{RESUMO}

\section{KAMIMURA, A. A efetivação dos direitos humanos: o desafio do direito no}

atendimento interdisciplinar às vítimas de violência. 2009. 191f. Dissertação (Mestrado) - Faculdade de Direito. Universidade de São Paulo, São Paulo, 2009.

$\mathrm{O}$ presente trabalho estuda os desafios do atendimento interdisciplinar às vítimas de violência e a efetivação dos direitos humanos. O debate em torno da violência raramente aborda a questão da vítima e da política de assistência às vítimas de violência. Os serviços que oferecem apoio $\mathrm{e}$ atendimento às vítimas trabalham geralmente em equipe multidisciplinar e os operadores do direito raramente possuem formação que privilegie o diálogo e troca com outros profissionais. Assim, esse estudo se justifica pela importância da análise sobre a maneira pela qual o direito tem participado do atendimento interdisciplinar à vítima de violência e como isso tem contribuído para promover o respeito aos direitos humanos. Para tanto, foram realizadas entrevistas com profissionais da área jurídica, psicológica e social que compõem as equipes do Centro de Referência às Vítimas de Violência (CNRVV) e do Centro de Referência e Apoio à Vítima (CRAVI). A partir do discurso desses técnicos, foram analisados como se dá a integração e prática interdisciplinar de atendimento às vítimas de violência nesses centros; quais conceitos ou tipos de vítimas são atendidas no serviço; como o direito tem contribuído no atendimento às vítimas e se a abordagem de direitos humanos é empregada nos atendimentos. A invisibilidade da vítima de violência é verificada na situação de desamparo diante da ausência de medidas legislativas adequadas ao exercício dos direitos das vítimas, na constante vitimização secundária no decorrer de procedimentos judiciais e na inconsistência de uma política de assistência às vítimas de violência. A consolidação dessa política deve se realizar sob o marco dos direitos humanos. $\mathrm{O}$ atendimento interdisciplinar a vítimas de violência apresenta desafios ao direito, que ainda tem um lugar a ser desvendado nessa prática.

Palavras-chave: Direitos Humanos. Violência. Vítima. Atendimento interdisciplinar . 


\begin{abstract}
KAMIMURA, A. The enforcement of human rights: the challenge faced by the law in the interdisciplinary support for violence victims. 2009. 191f. Dissertation (Master of Law) - Faculdade de Direito. Universidade de São Paulo, São Paulo, 2009.

The present work studies the challenges of the interdisciplinary support for violence victims and the enforcement of human rights. The debate about the violence rarely approaches the question of the victim and the politics of support to the violence victims. The services that provide support for victims generally work with multidisciplinary team and the lawyers do not have background that stimulate the dialogue and the exchanges with other professionals. Thus, this study is important for the analysis on how the law has participated in the interdisciplinary support for violence victim and how it has contributed to promote human rights. For this reason, we carried interviews with professionals of legal, psychological and social area of the Centro de Referência às Vitimas de Violência (CNRVV) and of the Centro de Referência e Apoio à Vitima (CRAVI). From the speech of these teams, we analyzed how these centers integrate different areas in the practical of support for violence victims; how the law has contributed in the support for the victims and if the service provided has human rights approach. The invisibility of the violence victim is verified with the lack of legislative measures to promote the victims' rights, the (re)traumatization of victims who face the judicial process and the lack of a support policy for violence victims. The consolidation of this policy must incorporate human rights approach. The support for violence victims presents challenges to the law that still has a place to be unmasked in this practical.
\end{abstract}

Keywords: Human Rights. Violence. Victim. Interdisciplinary support. 


\section{SUMÁRIO}

INTRODUÇÃO

Capítulo 1: Vítimas de violência 20

1.1. Vítimas e vitimização 20

1.2. Alguns instrumentos normativos internacionais sobre vítima 24

1.3. Breves apontamentos sobre a reparação às vítimas no Brasil 28

1.4. Breve análise da legislação sobre vítima no Brasil 30

Capítulos 2: Direitos humanos e vítimas de violência 35

2.1. Breves apontamentos sobre direitos humanos e atendimento à vítima 42

2.2. A experiência do Tribunal Penal Internacional 48

2.3. A Experiência da Corte Interamericana de Direitos Humanos 54

PARTE II - ATENDIMENTO ÀS VITIMAS DE VIOLÊNCIA NO BRASIL 57

Capítulo 3: O Centro de Referência às Vítimas de Violência (CNRVV) 59

3.1. breve apresentação da instituição: histórico e missão 59

3.2. perfil da equipe do centro e das vítimas atendidas 66

3.3. descrição do trabalho desenvolvido no centro 69

3.4. acolhimento e trabalho interdisciplinar 74

3.5. dificuldades 82

3.6. o papel do direito no atendimento às vítimas de violência - vítimas, direitos humanos e casos exemplares

Capítulo 4: O Centro de Referência e Apoio à Vítima (CRAVI) ........................... 97

4.1. breve apresentação da instituição: histórico e missão …........................................ 98 
4.2. perfil da equipe do centro e das vítimas atendidas

4.3. descrição do trabalho desenvolvido no CRAVI 108

4.4. acolhimento e trabalho interdisciplinar 116

4.5. dificuldades 120

4.6. o papel do direito no atendimento às vítimas de violência - vítimas, direitos humanos e casos exemplares

PARTE III - CONSIDERAÇÕES FINAIS: O DESAFIO DA CONSOLIDAÇÃO DE UMA POLÍTICA DE ATENDIMENTO A VÍTIMAS DE VIOLÊNCIA ............. 154

Políticas Federais de atendimento às vitimas de violência ......................................... 154 CNRVV e CRAVI: semelhanças e diferenças entre dois centros de referência à vítima de violência 159

O direito no atendimento às vítimas de violência: um lugar a ser construído 173

BIBLIOGRAFIA 


\section{INTRODUÇÃO}

Não obstante o discurso sobre a violência seja recorrente, pouco se debate sobre as vítimas de violência. Apesar dos investimentos para instalação e manutenção de centros de atendimento às vítimas de violência, a estrutura nem sempre é adequada para o suporte e apoio necessários. Embora os elevados índices de violência, o poder público e a sociedade em geral resistem em enfrentar o problema na sua complexidade; privilegiando-se medidas repressivas e punitivas, nem sempre com uma articulação com medidas de promoção social. E a vítima permanece ignorada, muitas vezes sem saber sequer que tem direitos, assim como o agressor.

Durante dois anos tive a oportunidade de me deparar cotidianamente com essas ambigüidades e desafios do atendimento às vítimas de violência e com a construção instigante de uma interdisciplinaridade entre as áreas jurídica, social e psicológica. Essa rica experiência me conduziu ao estudo - em monografia ${ }^{1}$ para obtenção de título de especialista em direitos humanos - sobre as questões referentes às vítimas de violência e ao atendimento interdisciplinar. A partir da análise da política de atendimento a familiares de vítimas de violência fatal no Centro de Referência e Apoio à Vítima (CRAVI), foram discutidos desafios e possibilidades do atendimento interdisciplinar e a linguagem dos direitos humanos como um lugar fundamental nesse atendimento, destacando-se a contribuição do direito nessa prática.

Mas esse estudo não se mostrou suficiente, principalmente em relação à construção da interdisciplinaridade no atendimento às vítimas de violência e à contribuição do direito nessa prática. Quais desafios se impõem à prática interdisciplinar no atendimento às vítimas? Qual o papel dos operadores do direito no apoio às vítimas de violência? Como o direito tem contribuído no atendimento às vítimas de violência? Como esse atendimento pode contribuir para a efetivação dos direitos humanos?

Em geral, a assistência jurídica é mais conhecida e demandada pela população, mas não é a única forma de atendimento às vítimas de violência. Outros atores, além dos operadores do direito, também têm responsabilidades no rompimento do ciclo de violência e podem contribuir para o acesso à justiça. Os operadores do direito são constantemente

\footnotetext{
${ }^{1}$ A monografia, sob orientação da profa. Dra. Flávia Inês Schilling, com título Linguagem e efetivação dos direitos humanos: o desafio do direito no atendimento interdisciplinar a vitimas de violência foi apresentada ao Curso de Especialização em Direitos Humanos da Faculdade de Direito da Universidade de São Paulo, como parte dos requisitos para obtenção de título de especialista em direitos humanos.
} 
convidados a solucionar questões de diversas áreas, mas sem uma formação que privilegie o diálogo e a troca. $\mathrm{O}$ direito, sozinho, não soluciona as questões relativas à violência e à vitimização. A composição entre diferentes olhares e formas de atuação pode possibilitar uma apropriação dos direitos de forma mais efetiva pelo sujeito em atendimento e, com base nisso, maior tendência a romper o ciclo de violência e vitimização.

Uma perspectiva de direitos humanos pode ser difundida e apropriada pela equipe de atendimento, a fim de que nas intervenções a noção de dignidade e de direitos humanos possa ser trabalhada sob diferentes aspectos no decorrer do atendimento. Da mesma forma, o diálogo e a hermenêutica diatópica podem contribuir para essa troca e interdisciplinaridade. Cada área contribui, ao seu modo, com seu olhar e intervenção. Mas restam ainda outras questões: como se dá essa construção? Qual o papel do direito no atendimento interdisciplinar às vítimas de violência?

Daí a importância do estudo e análise do desafio do direito no atendimento interdisciplinar a vítimas de violência como forma de efetivação dos direitos humanos. Há iniciativas, ainda pouco estudadas, que tentam essa integração, esse trabalho interdisciplinar e em rede.

Estudaremos a experiência de dois centros:

- CRAVI (Centro de Referência e Apoio à Vítima), programa da Secretaria da Justiça e da Defesa da Cidadania do Estado de São Paulo, que atende vítimas diretas e indiretas de violência fatal, doméstica e sexual;

- CNRVV (Centro de Referência às Vítimas de Violência), do Instituto Sedes Sapientiae, que atende vítimas de violência doméstica e sexual.

Essas instituições são pioneiras no campo específico de atuação e representam uma referência na temática de trabalho - seja em relação à violência doméstica e sexual, no caso do CNRVV; seja em relação à violência fatal, no caso do CRAVI. Essas instituições trabalham com equipe multidisciplinar e há uma tentativa de construção de uma rede interdisciplinar $^{2}$ - o que possibilitará um levantamento de desafios da abordagem interdisciplinar na efetivação dos direitos humanos. A violência objeto de cada instituição apontada é diversa, assim como o público atendido, o que possibilitará uma análise sobre diferentes políticas de atendimento a vítimas de violência - a partir de suas especificidades, composição da equipe, atividades desenvolvidas e desafios.

\footnotetext{
${ }^{2}$ O Centro de Referência a Vítima de Violência (CNRVV), do Instituto Sedes Sapientiae, não conta com uma equipe jurídica para atendimento, mas sim com parcerias para encaminhamento das questões jurídicas.
} 
Assim, pretendemos analisar de que forma a assistência jurídica é prestada nos dois centros de atendimento a vítimas de violência, e como se desenvolvem os trabalhos em conjunto com outros profissionais ou entidades para a prevenção e o tratamento da violência sofrida. Para, ao final, refletirmos sobre o papel do direito no atendimento interdisciplinar às vítimas de violência e sobre a efetivação dos direitos humanos por meio dessa política .

A parte I da dissertação apresenta algumas considerações sobre a violência, vitimização e direitos humanos. O capítulo 1 aborda o tema da vítima de violência, com a apresentação de alguns conceitos e seu campo normativo. O capítulo 2 analisa brevemente a teoria dos direitos humanos e sua relação com o atendimento às vítimas de violência.

A parte II trata da política de atendimento às vítimas de violência, a partir de entrevistas realizadas com os técnicos dos dois centros de atendimento às vítimas de violência. Os capítulos 3 e 4, respectivamente sobre o CNRVV e o CRAVI, descrevem as principais questões que emergiram das entrevistas realizadas com os profissionais desses centros. Esses capítulos desenvolvem, a partir do discurso da equipe, o histórico da instituição, o perfil dos entrevistados e das vítimas atendidas, o trabalho realizado no centro, a prática interdisciplinar, as dificuldades enfrentadas, algumas considerações sobre as vítimas e os direitos humanos, a contribuição do direito no atendimento às vítimas de violência e uma breve análise de casos exemplares relatados nas entrevistas.

Por fim, a parte III traz algumas considerações finais sobre o desafio da consolidação de uma política de atendimento às vítimas de violência, com uma breve descrição da política federal de atendimento às vítimas de violência, uma comparação das experiências dos dois centros analisados e uma discussão sobre o papel do direito no atendimento às vítimas. 


\section{Parte I}

\section{VIOLÊNCIA, VITIMIZAÇÃO E DIREITOS HUMANOS}

Na Parte I apresentaremos algumas considerações sobre os temas da violência, da vitimização e dos direitos humanos. Não analisaremos o contexto e o debate sobre a contemporaneidade e a complexidade da pós-modernidade; mas anunciaremos algumas questões relacionadas ao atendimento às vítimas de violência que serão desenvolvidas nos capítulos seguintes.

Entre 1980 e 2000, de acordo com o Sistema de Informação de Mortalidade, do Ministério da Saúde, foram registrados um total de 2.069.866 óbitos por causas externas; dos quais 82,2\% (1.700.885) foram de óbitos masculinos ${ }^{3}$. Em 2000, 59\% dos óbitos por causa externa $^{4}$ foram de brasileiros entre 15 e 39 anos; os jovens de 15 a 24 anos representaram $27 \%$ dessas mortes. Se na década de 80 os acidentes de trânsito representaram a maior causa de mortes por causas externas; na década de 90 a proporção de mortes por homicídios aumentou, representando 38\% dos óbitos. A taxa de mortalidade por homicídio em 2000 foi de 27 óbitos por cem mil habitantes; entre os homens essa taxa aumentou para 49,7 óbitos por cem mil habitantes. A arma de fogo foi utilizada em $68 \%$ dos óbitos por homicídio.

Entre 2003 e 2004 houve uma redução nos índices de homicídio. De acordo com Síntese de Indicadores Sociais 2005, do Instituto Brasileiro de Geografia e Estatística ${ }^{5}$, houve uma redução da taxa bruta de mortalidade, que representa a freqüência com que ocorrem os óbitos em uma população: caiu de 6,8\%o, em 1991, para 6,3\%o em $2004^{6}$. A mortalidade por causa externa é quase cinco vezes maior entre os homens entre 20 e 24 anos do que entre as mulheres nessa mesma faixa etária.

A taxa de mortalidade por causas externas entre os homens de 20 a 24 anos em 2004 foi de 170, 9 por cem mil habitantes. Em 2003 era 183,8 por cem mil habitantes; em 2000 era de 180,8; e em 1995 era de 170,2 por cem mil habitantes. Em 2004, a taxa de mortalidade entre os homens nessa faixa de 20 a 24 anos, por causas naturais, foi de 73,7

\footnotetext{
${ }^{3}$ De acordo com Instituto Brasileiro de Geografia e Estatística, Síntese de Indicadores Sociais 2003, p. 52.

${ }^{4}$ Óbito por causas externas é aquele por circunstância de ocorrência violenta, como: acidente de trânsito, afogamento, suicídio, homicídio, queda acidental etc.

${ }^{5}$ Não foram encontrados dados sobre a mortalidade por causa externa nas Sínteses de Indicadores Sociais de 2006 e 2007.

6 Conforme Síntese de Indicadores Sociais 2005, p. 27. Disponível em: http://www.ibge.gov.br/home/estatistica/populacao/condicaodevida/indicadoresminimos/sinteseindicsociais2 005/default.shtm (acesso em 26/01/08).
} 
por cem mil. Dentre as mulheres da mesma faixa etária, a taxa de mortalidade por causas naturais, naquele ano, foi de 18,0 por cem mil habitantes; em 1995 era 21,9 por cem mil habitantes ${ }^{7}$. Embora a ocorrência dessa violência seja maior em alguns estados da federação, a oferta de serviços de saúde que, direta ou indiretamente, atendem essas vítimas não é proporcional ${ }^{8}$.

Enquanto a violência fatal atinge mais os homens, a violência contra a mulher é maior no âmbito doméstico. Segundo estatísticas disponíveis e registros nas delegacias especializadas de crimes contra a mulher, em 2002, 70\% dos incidentes ocorrem dentro de casa e o agressor é o próprio marido ou companheiro; mais de $40 \%$ das violências resultam em lesões corporais graves decorrentes de socos, tapas, chutes, queimaduras, espancamentos e estrangulamentos; e essa violência compromete cerca de $10,5 \%$ do PIB do país ${ }^{9}$. Estima-se que, por ano, 275 milhões de crianças convivam em ambiente de violência doméstica e sofram suas conseqüências ${ }^{10}$. Não há estatísticas oficiais sobre os casos notificados de violência contra crianças e adolescentes no Brasil.

A compreensão sobre o tema da violência, em suas múltiplas dimensões, quer se trate da violência doméstica, da violência sexual, quer se trate dos homicídios, parece sempre escassa e insuficiente não obstante os diversos estudos sobre o tema. Nossa perplexidade frente à violência ocorrida, frente à banalização do mal e da impunidade, o (não) valor dado à vida humana (em especial quando se refere a grupos excluídos, ou marginalmente incluídos) faz com que busquemos motivos e respostas que possam, de alguma forma, nos ajudar a agir e a mudar a realidade que nos cerca. Essas questões, porém, permanecem sem respostas satisfatórias.

O debate em torno do tema da violência tende a ser pautado ora pela exigência de combate à impunidade ${ }^{11}$, maior repressão e recrudescimento punitivo, ora por demandas de políticas de promoção de justiça social. Em ambos os casos pouco se discute em relação às vítimas de violência, a suas necessidades e às ações para o tratamento dos danos ou reparação.

\footnotetext{
${ }^{7}$ De acordo com gráfico 1.18 da Síntese de Indicadores Sociais 2005 do IBGE, p. 67.

${ }^{8}$ Sobre o tema, ver Síntese dos Indicadores Sociais 2003 do IBGE.

9 De acordo com Relatório Nacional Brasileiro: Convenção sobre a eliminação de todas as formas de discriminação contra a mulher, 2002, p.68.

${ }^{10}$ De acordo com UNICEF, The State of the World's Children 2007.

${ }^{11}$ Vale ressaltar que a impunidade é combatida em relação a determinados delitos, mas não combatido na mesma intensidade em relação a todos os crimes. Basta analisar o recrudescimento punitivo em relação a crimes contra a vida e contra o patrimônio; sem a mesma intensidade em relação ao combate à corrupção e evasão de divisas, por exemplo.
} 
Acrescenta-se a esse quadro, por conta de uma forte resposta emocional diante da violência, reações aparentemente individuais e privadas - como blindagem de carros, condomínios fechados, segurança privada, sistema de câmeras de filmagem, dentre outros - e uma ampla sensação de insegurança. Tais respostas aparentemente individuais e privadas sustentam um sistema de "in-segurança” pública, que movimenta uma indústria de proteção e venda de serviços de segurança, em crescente e franca expansão no país.

Rancière aponta um cenário em que a guerra se mostra necessária, não para responder a uma situação real ou imaginária de insegurança, mas para manter um sentimento de insegurança necessário ao bom funcionamento do Estado, que é reduzido a um Estado policial: é a comunidade do medo que o sustenta. Nesse quadro, prevalece o sentimento de insuficiência de qualquer proteção contra as ameaças, sejam conhecidas ou ainda não imaginadas. Dessa forma, os recursos para a segurança são ilimitados e o sentimento de insegurança não é devido a circunstâncias transitórias, mas é, sobretudo, um modo de gestão da vida coletiva. O sentimento de insegurança "é um modo de gestão dos Estados e do planeta para reproduzir e renovar em círculo as próprias circunstâncias que o mantêm." $" 12$

Vale ressaltar a necessidade de políticas de segurança que saiam do imobilismo ou da lógica de repressão, distinguindo-se de medidas paliativas ou pautadas em acontecimentos divulgados na mídia. O problema da segurança pública deve ser enfrentado de forma integrada entre estratégias penais e sociais, conjugando-se a repressão-punição com distribuição e justiça social, e deve também contar com a participação de todos os atores sociais, tendo em vista o caráter coletivo e complexo do tema.

Por isso a necessidade de políticas públicas de segurança com abordagem transversal, multidisciplinar e multisetorial, que enfrentem esse panorama com respeito e promoção dos direitos humanos e com participação de diferentes atores sociais. Além da prevenção e da punição do crime, o combate à violência deve abordar também a atenção à vítima, que pode eventualmente reproduzir ciclo de violência. $\mathrm{O}$ atendimento às vítimas de violência possibilita a defesa e a promoção de direitos humanos, visto que as vítimas muitas vezes sentem-se intimidadas, convivendo com a sensação de medo e insegurança e por vezes distantes do exercício de direitos. Em outras situações, a pessoa sequer se enxerga como vítima e a violência passa a compor o cotidiano de maneira "natural" e banalizada. Ademais, algozes e vítimas de violência podem apresentar perfis semelhantes,

\footnotetext{
${ }^{12}$ Jacques Rancière, O princípio de insegurança. In: Mais! Folha de São Paulo, domingo, 21/09/03.
} 
pertencer aos mesmos segmentos sociais ${ }^{13}$ e permanecer aprisionados em circuitos de vitimização-agressão que precisam ser rompidos.

Embora o elevado índice de homicídios ${ }^{14}$, a discussão é pouco centrada no conceito de vítimas indiretas ou de vitimização difusa ocasionada pela violação de direito, ou sobre $\mathrm{o}$ atendimento aos vitimados.

Vale ressaltar que em 2004 ocorreu uma redução de 8,2\% dos homicídios no Brasil em relação aos anos anteriores, o que corresponde a mais de três mil vidas ${ }^{15}$. Há estudos que indicam que, levando em conta a tendência de aumento dos índices de homicídios nos anos anteriores, esse percentual de redução poderia atingir $24 \%{ }^{16}$. De acordo com o Ministério da Saúde ${ }^{17}$, os estados que mais contribuíram para a redução dos óbitos, em números absolutos, foram Rio de Janeiro e São Paulo. Em São Paulo, observou-se uma diminuição de 1.960 óbitos de 2003 para 2004. No Rio de Janeiro, ocorreu decréscimo de 672 óbitos em 2004 com relação a 2003. A mortalidade por arma de fogo pode ser acidental, por agressão (homicídio), suicídio e com intenção não determinada. A mortalidade por agressão (homicídio) é a mais freqüente, representando cerca de $90 \%$ da mortalidade por arma de fogo no Brasil.

Algumas hipóteses podem ser formuladas sobre essa redução, como o impacto da Campanha do Desarmamento de 2004 e a redução da circulação de armas de fogo, como sugere o documento mencionado. Além do controle de armas, pode-se destacar também uma integração nas ações governamentais e não-governamentais em algumas regiões (como no caso de Diadema); maior utilização de soluções pacíficas de controvérsias e conflitos (por meio de conciliação, mediação ou outras formas pacíficas de solução de

\footnotetext{
13 Vide pesquisa realizada com familiares de vítimas de homicídio: "Vidas Nuas, mortes banais: os homicídios em São Paulo através da fala de suas vítimas indiretas". Caderno de Resultados de Pesquisa realizada em parceria da Pontifícia Universidade Católica, Centro de Referência e Apoio à Vítima e Secretaria da Justiça e Defesa da Cidadania do Estado de São Paulo, 2003.

14 Segundo Relatório Mundial sobre Violência e Saúde de 2002, publicado pela Organização Mundial de Saúde, num universo de 1,6 milhão de mortes violentas no mundo, cerca de metade é ocasionada por suicídios; as guerras representam cerca de $18 \%$ do total; os homicídios representam $31,3 \%$ das mortes violentas no mundo, totalizando de 520 mil mortes. Brasil representa $14 \%$ dos homicídios em termos mundiais.

${ }^{15}$ De acordo com pesquisa "Impacto da campanha do desarmamento no índice nacional de mortalidade por arma de fogo" do Ministério da Saúde, de agosto de 2005. Disponível em: www.rolim.com.br/2002/_pdfs/pesquisa_min_saude_mortalidade_armas.pdf (acesso em 26/01/08). Sobre o tema, ver também "Desarmamento faz número de mortos por armas de fogo cair em todo o Brasil", Disponível em: http://www.comunidadesegura.org/?q=pt/node/24593 (acesso em 26/01/08).

${ }^{16}$ De acordo com "Impacto da violência armada sobre os jovens e modelo de intervenção". Disponível em: http://www.comunidadesegura.org/?q=pt/node/37930 (acesso em 26/01/08).

${ }^{17}$ Ministério da Saúde, "Impacto da campanha do desarmamento no índice nacional de mortalidade por arma de fogo", agosto de 2005.
} 
conflitos); envolvimento da população local nos mecanismos de segurança (por exemplo, com a formação de grupos e fóruns de defesa comunitários ${ }^{18}$ ); policiamento comunitário e preventivo; integração das ações de policiamento e de investigação; aperfeiçoamento dos mecanismos de justiça criminal (investimento na inteligência da polícia, investigação e acusação dos autores de crimes etc); mapeamento de focos de violência e ações integradas de enfrentamento etc. Outra hipótese é em relação aos registros dessas ocorrências - por exemplo, os agentes de justiça podem registrar de outras formas as mortes violentas; o que poderia diminuir o número de homicídios e aumentar a quantidade de boletins de ocorrência classificadas como "morte a esclarecer", "encontro de cadáver" ou "resistência seguida de morte". Sabe-se que a maioria dos dados sobre óbito por causas externas são colhidas nos equipamentos de saúde, nos quais também seria possível registros diversos sobre fenômenos semelhantes ou o "não registro".

Outra hipótese é que as ações integradas de prevenção à violência e repressão ao crime contribuíram bastante para essa redução. A repressão ao crime, aliada à prevenção, com respeito aos direitos fundamentais dos acusados e outros envolvidos parece fundamental para a redução de violência. A violência é um fenômeno complexo e coletivo, dessa forma, somente ações isoladas e individuais dificilmente surtiriam impacto significativo nessa redução. A integração de diferentes atores e diversas ações conjugadas pode ter contribuído para a crescente redução dos homicídios.

A relação entre a queda do índice de homicídio e a questão das vítimas - diretas e indiretas - é pouco usual e debatida. Mas pode-se imaginar, por exemplo, uma eventual diminuição de "comportamentos de risco" ou "situações de risco" por alguns grupos vulneráveis a essa violência; ou maior oferta e qualidade de serviços de assistência à vítima e proteção à pessoa ameaçada, dentre outras possibilidades. O debate sobre as vítimas, seus direitos e os serviços de assistência oferecidos é escasso e insuficiente.

A invisibilidade da vítima deve ser combatida com seu reconhecimento como sujeito de direitos e com a promoção dos direitos humanos, sem a "demonização" ou a "glamourização" do vitimado. Nesse contexto, destacam-se o combate à impunidade dos violadores e a necessidade de uma política de assistência às vítimas de violência, como forma de defesa e promoção dos direitos humanos.

\footnotetext{
${ }^{18}$ Veja o exemplo do Fórum em Defesa da Vida, no Jardim Ângela, e as ações integradas envolvendo diversos atores governamentais, não-governamentais e população local para combate à violência.
} 
Sobre a política de atendimento a vítimas, "é imperativo ter, como eixo de trabalho, a história de como a violência faz parte da vida destas pessoas e destas famílias e do local onde moram ou moravam. $\mathrm{O}$ atendimento profissional aos familiares das vítimas fatais tem como pilastras centrais: a interdisciplinaridade, o desenvolvimento da capacidade de escuta e a compreensão das relações sujeito e ambiente social". ${ }^{19}$

A prática da assistência à vítima enfrenta diversos desafios. No atendimento a vítimas de violência, a questão jurídica parece mais visível e exigida, ainda que questões sociais ou psicológicas também estejam presentes. Entretanto, como se dá a relação entre essas áreas? Como se dá o diálogo e a troca entre direito, psicologia e serviço social?

O direito estatal não alcança todas situações, como se verifica em diversas situações diante do pluralismo jurídico. A chamada "lei do silêncio" em determinadas comunidades, as rígidas sanções frente ao descumprimento de regras dos grupos, o medo de testemunhar em juízo e ameaças são alguns exemplos na insuficiência do direito estatal para a solução do problema da violência.

A intervenção no ciclo da violência requer a atuação de diferentes atores e o direito tem importante papel no rompimento do ciclo e na promoção e defesa dos direitos humanos. Não apenas o advogado, o delegado de polícia, o defensor público, o promotor de justiça e o juiz intervêm e acompanham diversos casos de violência e vitimização. Os familiares da vítima, amigos, professores, assistentes sociais, psicólogos, conselheiros tutelares, dentre outros, também participam direta ou indiretamente da resolução de situações de violência. A linguagem dos direitos humanos ainda se mostra pouco incorporada e difundida entre os profissionais de áreas como o serviço social, a psicologia, a pedagogia, dentre outros.

Além disso, os operadores do direito continuam com formação jurídica legalista e técnica, com pouco diálogo e troca com outras disciplinas e muitas vezes distante da realidade brasileira - não obstante tal forma de ensino jurídico seja debatido e criticado entre os próprios juristas ${ }^{20}$.

\footnotetext{
${ }^{19}$ Guia de Recomendações Metodológicas para Atenção aos familiares de vítimas fatais, resultado de pesquisa realizada pelo Núcleo de Violência da Faculdade de Serviço Social da PUC/SP em parceria com o Centro de Referência e Apoio à Vítima de Violência - CRAVI - da Secretaria da Justiça e Defesa da Cidadania do Governo do Estado de São Paulo, com apoio da FAPESP, 2003.

${ }^{20}$ Não aprofundaremos uma discussão sobre o ensino jurídico "tradicional", que privilegia o processo judicial e a formação eminentemente técnica-jurídica, em relação a uma formação jurídica que favoreça o acesso à justiça (e não apenas ao judiciário) e o exercício dos direitos por todos os cidadãos, em interação com outras áreas do conhecimento, sem ignorar o contexto social brasileiro. Para maiores informações, ver publicações da Associação Brasileira de Ensino do Direito (ABEDi).
} 
Há ainda os riscos de vitimização secundária ${ }^{21}$ : a pessoa que já sofreu uma violação de seu direito pode experimentar novamente outra violação, praticada por algum agente do sistema de justiça, o que pode agravar as conseqüências da vitimização primária. A violência pode também atingir outras pessoas, além da vítima direta que tenha suportado o ato violento. A vitimização indireta amplia a compreensão do sofrimento gerado em decorrência do crime, tendo em vista que a violência perpetrada contra a vítima reverbera em outros contextos, atingindo, de forma diferenciada e difusa, outras pessoas que pertencem ao círculo de convivência da vítima direta e que podem também sofrer os efeitos da violência perpetrada. Essa noção de vitimização indireta é recente e desafiadora.

Vítimas e algozes freqüentam os mesmos bairros e os homicídios ocorrem nas proximidades das residências das vítimas em $48 \%$ dos casos analisados em pesquisarealizada com familiares de vítimas de homicídios praticados entre 1998 a $1999^{22}$. Entretanto, grande parte dos homicídios praticados são arquivados durante as investigações em fase de inquérito policial por não apresentarem autoria conhecida; somente ínfima porcentagem dos crimes contra a vida culmina em final condenação do réu. Com isso, a desconfiança nas instituições pode aumentar e caminhar ao lado do desejo de vingança.

O diálogo e a troca entre diferentes saberes podem contribuir para analisar a realidade social e identificar as necessidades de proteção e de promoção dos direitos humanos. Para tanto, as diferenças devem ser vistas como potencialidades e a cooperação entre as diferentes áreas deve ser constante. Diferentes formas de intervenção - pelo psicólogo, pelo assistente social ou pelo advogado - podem contribuir para a mudança da posição de vítima para outra com maior exercício de direitos? De que forma os direitos humanos podem contribuir na interdisciplinaridade do atendimento a vítimas de violência?

Aprofundaremos nos capítulos seguintes algumas considerações sobre as vítimas de violência e os direitos humanos.

\footnotetext{
${ }^{21}$ Vide capítulo 1 sobre Vítimas de violência.

${ }^{22}$ Vidas Nuas, mortes banais: os homicídios em São Paulo através da fala de suas vítimas indiretas. Caderno de Resultados de Pesquisa realizada em parceria da Pontifícia Universidade Católica, Centro de Referência e Apoio à Vítima e Secretaria da Justiça e Defesa da Cidadania do Estado de São Paulo, 2003.
} 


\section{Capítulo 1: VÍTIMAS DE VIOLÊNCIA}

Nesse capítulo será abordado o tema da vítima de violência. Será desenvolvida uma conceituação inicial de vítima (direta, indireta, difusa) e vitimização (primária, secundária e terciária), assim como uma discussão sobre um conceito de vítima e os desafios decorrentes - como a invisibilidade de algumas vítimas e vitimizações, o conceito proposto em legislações nacionais e internacionais, dentre outros aspectos. Justificamos o recorte e a breve análise de conceitos, histórico e reflexão teórica, vez que faremos apenas algumas considerações sobre o tema para orientar a discussão de questões que possam emergir no decorrer da dissertação, pois o foco do presente estudo é analisar como essas questões emergem no discurso dos profissionais de centros de atendimento às vítimas de violência.

\subsection{Vítimas e vitimização}

O termo "vítima" é bastante vago e amplo; no senso comum confunde-se com aquele que sofreu qualquer forma de injustiça ou de dano. Qualquer pessoa pode se identificar como vítima diante do medo disseminado ${ }^{23}$. Embora nem sempre relacionado a um direito, o termo pode se referir a diferentes violações - como vítima de crime, vítima de violência, vítima de discriminação, dentre outros.. Juridicamente ${ }^{24}$, utiliza-se conceitos como vítima, ofendido, lesado ou prejudicado.

Num breve histórico ${ }^{25}$ sobre a participação da vítima em processo judicial, verificamos que na chamada "Idade de Ouro", a vítima ocupava uma posição de destaque, numa época em que a lei disciplinava o exercício da vingança. Tal período não indica determinado período histórico, pois não há um termo inicial ou final preciso. Mas nos primórdios da civilização, a vítima exercia um importante papel na vingança ou justiça privada.

Numa fase posterior, de "ostracismo", a vítima era praticamente esquecida e ignorada pelo direito. A vítima deixa de ter um papel central na solução do conflito penal e o Estado passa a exercer um poder punitivo e assume um papel de jus puniendi, com a

\footnotetext{
${ }^{23}$ Não desenvolveremos a noção de "vítima virtual" e disseminação do medo pela mídia; para aprofundar esse tema, ver produção de Paulo Vaz, dentre outros.

${ }^{24}$ Não serão analisadas definições sobre vítimas por diferentes áreas do saber, ou pelo própria vítima, mídia ou outros atores. Faremos apenas uma apresentação preliminar (e até superficial) sobre o conceito de vítima, a fim de subsidiar as discussões nos capítulos seguintes.

${ }^{25}$ Sobre o papel da vítima na apuração e punição de crimes, ver Ana Sofia Schimidt de Oliveira, $A$ vítima e o processo penal. São Paulo: Editora RT, 1999; e Antonio Scarance Fernandes, O papel da vítima no processo penal, São Paulo, Malheiros Editores, 1995; dentre outros.
} 
detenção exclusiva do monopólio da reação penal - o que neutraliza o papel da vítima. As antigas práticas privadas passam a ceder lugar a uma nova concepção de justiça, em que o Estado exerce um poder exterior às partes envolvidas no litígio. Nesse cenário surge a figura do procurador, o qual representa o soberano e "substitui" a vítima.

Alguns autores indicam uma fase atual de "redescobrimento" da vítima no processo penal $^{26}$; em que o Estado é o principal responsável pela apuração e punição do crime, com uma tímida participação ${ }^{27}$ da vítima no processo penal e aproximação do tema nos estudos acadêmicos. Nesse sentido, é interessante observar a experiência do Tribunal Penal Internacional, o qual prevê uma Unidade de Apoio às Vítimas e Testemunhas e uma Seção para Participação e Reparação das Vítimas. Observa-se também um novo enfoque na atuação estatal além da esfera repressiva-punitiva, com a criação de programas de proteção e assistência às vítimas, que passam a ser observados como alvo de políticas públicas destaca-se a criação de programas de atendimento a crianças e adolescentes vítimas de violência doméstica, programas de atendimento a mulheres vítimas de violência, dentre outros.

Embora o termo "vítima" nos remeta a diferentes noções, ressalta-se a idéia trazida na Declaração dos Princípios Fundamentais de Justiça Relativos às Vítimas da Criminalidade e de Abuso de $\operatorname{Poder}^{28}$ - a qual define, em seu artigo $1^{\text {o }}$, vítimas como "as pessoas que, individual ou coletivamente, tenham sofrido um prejuízo, nomeadamente um atentado à sua integridade física ou mental, um sofrimento de ordem moral, uma perda material, ou um grave atentado aos seus direitos fundamentais, como conseqüência de atos ou de omissões violadores das leis penais em vigor num Estado membro, incluindo as que proíbem o abuso de poder". Considera-se também vítima aquele(a) que sofreu dano ou lesão, independentemente de laços de parentesco com o autor, seja ou não identificado, preso, processado ou declarado culpado.

O termo vítima inclui também, de acordo com o artigo $2^{\circ}$ da Declaração, "a família próxima ou as pessoas a cargo da vítima direta e as pessoas que tenham sofrido um prejuízo ao intervirem para prestar assistência às vítimas em situação de carência ou para impedir a vitimização". Assim, a definição da Declaração dos Princípios Fundamentais de

\footnotetext{
${ }^{26}$ Não há consenso na doutrina sobre as "fases" da vítima ao longo da história, como anteriormente descrito. Há ampla discussão sobre o "redescobrimento" da vítima.

27 Verifica-se que algumas legislações mais recentes condicionam o prosseguimento do processo à participação da vítima.

${ }^{28}$ Declaração adotada, em 29 de novembro de 1985, pela Assembléia Geral do Alto Comissariado das Nações Unidas para os Direitos Humanos (Resolução 40/34).
} 
Justiça Relativos às Vítimas da Criminalidade e de Abuso de Poder de 1985 inclui o conceito de vítima indireta, ampliando a compreensão da vitimização provocada pela violação além da pessoa da vítima direta, a qual suportou o ato violento ${ }^{29}$.

Essa definição sobre vítima e seus direitos abrange a noção de vítima direta e indireta, mas pouco esclarece em relação à vítima difusa - atingida de maneira indiscriminada pela violação e seu impacto. Tal noção de vitimização difusa é recente e desafiadora. Estamos acostumados a imaginar a violência e o crime de uma forma esquematizada em que o agressor atinge a vítima e o Estado intervém (seja representado pelo policial, delegado, promotor ou juiz); entretanto, pouco refletimos sobre outras pessoas também atingidas pela violação: a família dessa vítima direta, os amigos e conhecidos, a vizinhança do local dos fatos, a "comunidade", os profissionais de saúde e de controle social que atendem essa ocorrência, dentre outros.

Vale ressaltar que a violência pode atingir outras pessoas, além da vítima direta que tenha suportado o ato violento. Nesse sentido, a vitimização indireta ou difusa amplia a compreensão do sofrimento gerado em decorrência da violação, tendo em vista que a violência perpetrada contra a vítima reverbera em outros contextos, atingindo também, de forma diferenciada e coletiva, outras pessoas que podem pertencer ao círculo de convivência da vítima direta e sofrer os efeitos da violência perpetrada.

Não se verifica um consenso em relação à extensão do conceito de vítima ${ }^{30}$, que pode ser mais ou menos restritivo. No sistema interamericano, de acordo com o Regulamento da Corte Interamericana de Direitos Humanos, considera-se vítima toda pessoa cujos direitos protegidos na Convenção Americana de Direitos Humanos se alega terem sido violados. Já no Tribunal Penal Internacional, vítimas são as pessoas naturais que tenham sofrido um dano como conseqüência do cometimento de algum crime de competência do Tribunal; incluindo-se também as organizações ou instituições que tenham sofrido danos diretos a algum de seus bens que esteja dedicado à religião, à instrução, às artes, às ciências ou à benevolência, e a seus monumentos históricos, hospitais e outros

\footnotetext{
${ }^{29}$ Essa definição de vítima é contemplada nos Princípios e Diretrizes Básicos sobre o Direito das Vítimas de Violações das Normas Internacionais de Direitos Humanos e do Direito Internacional Humanitário a Interpor Recursos e Obter Reparações - Resolução 60/147, adotada pela Assembléia Geral das Nações Unidas, em 16 de dezembro de 2005.

${ }^{30}$ Não abordaremos as diversas categorias e conceitos de vítima. Adotaremos o conceito de vítima constante da Declaração dos Princípios Fundamentais de Justiça Relativos às Vitimas da Criminalidade e de Abuso de Poder. Para maiores informações sobre a vítima no direito penal, processo penal, crimonologia ou vitimologia, consultar: Ana Sofia Schmidt de Oliveira, Antonio Scarance Fernandes, Elena Larrauri Pijoan, Antonio García-Pablos de Molina, Edgard de Moura Bittencourt, dentre outros
} 
lugares e objetos que tenham fins humanitários - de acordo com a regra $\mathrm{n}^{\mathrm{o}} .85$ das Regras de Procedimentos e Provas do Tribunal. Essa definição tem como antecedente a já mencionada Declaração de 1985; mas não é específica em relação a vitimização direta ou indireta.

O conceito de vítima carrega ambigüidades e complexidade. Evidentemente, o comportamento e a reação das vítimas não são uniformes e dependem de uma série de fatores, como a personalidade, condição social e pessoal, violação da qual foi vitimada, dentre outros. Os familiares de vítimas de crimes fatais, por exemplo, muitas vezes não se reconhecem como vítimas e sujeitos de direito, tendendo a "esquecer", "deixar de lado" ou “apagar da memória" a violência ocorrida, como uma reação de defesa imediata ao sofrimento, medo, impotência, isolamento ou descrença nas instituições públicas de repressão da violência e distribuição de justiça. A vítima de violência sexual muitas vezes sente-se envergonhada e/ou culpada e não se reconhece como sujeito de direitos.

Em relação aos familiares de vítimas diretas de violência fatal, estudados em monografia anteriormente citada, verificou-se que essas vítimas indiretas apresentavam, em geral, um comportamento de passividade e aceitação dos fatos, ou uma atuação excessiva e discursos de vingança. Algumas vítimas indiretas, após a morte violenta do familiar, passaram a se isolar do convívio social e passivamente aceitar ou se conformar com a perda ou dano, sem se reconhecer como sujeitos de direitos e responsáveis por mudanças. Por outro lado, outras vítimas pareciam caminhar para uma atuação excessiva ${ }^{31}$, sem ponderar riscos ou ameaças em atitudes suicidas ou vingativas. $\mathrm{O}$ sofrimento justificaria qualquer atitude praticada, desumanizando-se o infrator e negando-lhe direitos.

Ambas, a passividade ou a atividade excessiva, demonstram os riscos existentes ao próprio sujeito e ameaçam a efetivação dos direitos humanos na medida em que negam ou dificultam o exercício de direitos de determinados sujeitos e tendem a reproduzir ciclos de violência. As respostas às violações de direitos humanos devem também considerar vítimas direta ou indiretamente atingidas pela violação.

Vale ressaltar o risco de vitimização secundária, praticada em geral pelas instâncias formais de controle social, o que pode dificultar o processo de superação da violência. As

\footnotetext{
${ }^{31}$ A passividade da vítima tende a conduzir a pessoa a uma posição de "recebedora de favores", em que os direitos são assimilados como favores ou benesses, como uma forma de compensação pelo sofrimento experimentado, sem uma postura de reivindicação de direitos. A atividade excessiva pode confundir-se com uma defesa para não lidar com a dor e o sofrimento provocados, ou ainda caminhar para atitudes baseadas em noções vingativas (buscar a "Justiça desejada", "custe o que custar", ou "com as próprias mãos"), afastandose do exercício de direitos.
} 
normas internacionais de direitos humanos indicam constantemente a necessidade de formação e sensibilização de agentes de polícia, justiça, saúde, dentre outras áreas, para atenção às necessidades das vítimas e prevenção de outra vitimização.

A vitimização primária é normalmente entendida como aquela provocada pelo cometimento do crime, pela conduta violadora dos direitos da vítima. Pode causar danos variados, materiais, físicos, psicológicos, de acordo com a natureza da infração, personalidade da vítima, relação com o agente violador, extensão do dano, dentre outros.

Por vitimização secundária, entende-se aquela causada pelas instâncias formais de controle social, no decorrer do processo de registro e apuração do crime. Ocorrido o crime, deve-se registrar a ocorrência e, em alguns casos, é preciso realizar um exame de corpo de delito, dentre outras providências. O sistema de justiça pode violar outros direitos nesse processo, vitimizando novamente o cidadão. Condutas ou comentários discriminatórios, demoras excessivas na finalização do processo, ausência de orientação sobre providências necessárias, dentre outros exemplos. A pessoa que já sofreu uma violação de seu direito experimenta novamente outra violação, desta vez, geralmente praticada por algum agente estatal do sistema de justiça - o que pode agravar as conseqüências da vitimização primária.

A vitimização secundária pode dificultar o processo de superação do fato e elaboração da violência vivenciada, pode ainda aumentar a descrença nas instituições públicas, ou ainda provocar uma sensação de impotência, desamparo e frustração em relação ao sistema de justiça.

Assim, faz-se necessária uma política de atenção às vítimas de violência, a fim de se promover efetivação dos direitos humanos e evitar que tais vítimas, descrentes do sistema de justiça e revoltadas com a violência sofrida, violem direitos de outros, perpetuando e reproduzindo ciclo de violência e violação de direitos. Destaca-se ainda a importância de promoção de uma cultura de direitos humanos, em que todos os atores se comprometam com o tema, tendo em vista o caráter coletivo da violência.

\subsection{Alguns instrumentos normativos internacionais sobre vítima}

A Declaração dos Princípios Fundamentais de Justiça Relativos às Vítimas da Criminalidade e de Abuso de Poder (Resolução 40/34), adotada pela Assembléia Geral do Alto Comissariado das Nações Unidas para os Direitos Humanos em 29 de novembro de 
1985, ressalta a importância do acesso à justiça e tratamento eqüitativo, obrigação de restituição e de reparação, indenização e serviços a vítimas da criminalidade.

Recomenda que seja assegurado o acesso às instâncias judiciárias e a uma rápida reparação do prejuízo por si sofrido (artigo $4^{\circ}$ ), que a vítima seja informada de seus direitos $\left(\operatorname{artigo~} 5^{\circ}\right.$ ) para buscar a reparação por esses meios. Indica ainda que o aparelho judiciário e administrativo seja capaz de responder às necessidades das vítimas, informando-lhes sua função, as possibilidades de recurso, andamento e decisões do processo (artigo $6^{\circ}$, a); prestando à vítima assistência adequada ao longo de todo o processo (artigo $6^{\circ}, \mathrm{c}$ ); tomando medidas para minimizar, o quanto possível, as dificuldades encontradas pela vítima, protegendo sua vida privada, garantindo sua segurança, assim como de seus familiares e testemunhas (artigo $6^{\circ}, \mathrm{d}$ ); evitando demoras desnecessárias na resolução das causas e na execução das decisões ou sentenças que lhes concedam a indenização (artigo $\left.6^{\mathrm{o}}, \mathrm{e}\right)$.

Essa Declaração aponta ainda para a criação de serviços de assistência material, médica, psicológica e social de que necessitam as vítimas da criminalidade, além do dever de prestar informações sobre serviços que lhes possam ser úteis. Recomenda ainda a formação e sensibilização de agentes de polícia, justiça, saúde e outros serviços, para as necessidades das vítimas e elaboração de instruções que garantam pronta e adequada intervenção, atendendo-se as necessidades especiais em razão da natureza do prejuízo sofrido ou característica pessoal da vítima (artigos 14 a 17).

A Resolução 60/147, adotada pela Assembléia Geral em 16 de dezembro de 2005 Princípios e Diretrizes Básicos sobre o Direito das Vítimas de Violações das Normas Internacionais de Direitos Humanos e do Direito Internacional Humanitário a Interpor Recursos e Obter Reparações - prevê a obrigação de o Estado respeitar, assegurar o respeito e implementar as normas internacionais de direitos humanos e de direito humanitário, a fim de assegurar a interposição de recurso e reparação. E recomenda que “os Estados adotem os Princípios e Diretrizes Básicos, promovam seu respeito e chamem a atenção dos membros de órgãos executivos do governo, em especial os funcionários encarregados do cumprimento da lei e as forças militares e de segurança, os órgãos do legislativo, o poder judiciário, as vítimas e seus representantes, os defensores e advogados de direitos humanos, os meios de comunicação e o público em geral”.

Tais Princípios e Diretrizes Básicos adotam uma perspectiva orientada na vítima e descrevem o escopo do direito à reparação e as possíveis medidas a serem adotadas para 
sua realização. Nesse contexto, os Estados devem assegurar que a legislação interna seja compatível e harmônica com as normas internacionais de proteção dos direitos humanos por meio da incorporação dessas normas internacionais no ordenamento jurídico interno. Os Estados devem adotar medidas adequadas e efetivas para promover o acesso à justiça, de forma efetiva, célere e justa; e devem prover medidas adequadas, efetivas, céleres e apropriadas, inclusive para a reparação. Os Estados devem também assegurar que a legislação doméstica promova pelo menos o mesmo nível de proteção das vítimas como o requerido pelas obrigações internacionais.

Essas obrigações dos Estados incluem o compromisso de promover adequadas medidas legislativas e administrativas para a prevenção das violações de direitos humanos e de direito internacional humanitário; de investigar efetiva, rápida e imparcialmente as violações e punir os responsáveis; prover àquelas que reclamam a situação de vítimas o acesso igualitário e efetivo à justiça; assim como de prover efetivos remédios às vítimas inclusive de reparação.

O tratamento das vítimas também é contemplado nos Princípios e Diretrizes Básicos (parágrafo 10): as vítimas devem ser tratadas com humanidade e respeito a sua dignidade e seus direitos humanos; e medidas apropriadas devem ser tomadas para assegurar a segurança, bem-estar físico e psicológico e privacidade das vítimas, assim como em relação a seus familiares. Esses princípios destacam ainda a necessidade de se evitar a vitimização secundária na medida em que prevê que os Estados devem assegurar que na legislação doméstica seja garantido que a vítima de violência e trauma seja beneficiada por atenção e cuidados especiais para evitar uma "revitimização" no curso dos procedimentos legais e administrativos para promover a justiça e reparação.

Os remédios para as graves violações de direitos humanos e de direito internacional humanitário incluem: (a) os direitos da vítima de acesso à justiça de forma igualitária e efetiva; (b) o direito a adequada, efetiva e célere reparação dos danos sofridos; e (c) o acesso a informações relevantes concernentes às violações e aos mecanismos de reparação.

(a) $\mathrm{O}$ acesso à justiça inclui o dever de o Estado disseminar informações sobre todos os mecanismos disponíveis de proteção e defesa em relação a graves violações de direitos humanos e direito humanitário; dever de tomar medidas para minimizar o inconveniente para as vítimas e seus representantes; e o dever de proteger contra interferências arbitrárias em sua privacidade e assegurar sua segurança e proteção contra ameaças e intimidação de vítimas e de seus familiares e testemunhas, durante e após os 
procedimentos judiciais, administrativos e outros procedimentos que afetem os interesses das vítimas. Os deveres do Estado abrangem também prover efetiva assistência às vítimas para o acesso à justiça; e disponibilizar todo um aparato legal, diplomático e consular para que as vítimas tenham assegurado o exercício de seus direitos à defesa e à proteção em face de graves violações de direitos humanos e direito internacional humanitário. Vale ressaltar que o acesso à justiça tem abrangência individual e também coletiva para grupos de vítimas.

(b) A reparação pelos danos sofridos deve ser proporcional à gravidade das violações e os danos suportados pelas vítimas em razão de atos ou omissões do Estado. Nesse sentido, a Resolução 60/147 ressalta a necessidade de os Estados se comprometerem com o estabelecimento de programas nacionais para reparação e outras assistências às vítimas; assim como de os Estados preverem na legislação doméstica mecanismos efetivos para a efetiva realização de julgamentos de reparação.

A completa e efetiva reparação inclui a restituição, compensação, reabilitação, satisfação e a garantia de não-repetição.

A restituição deve, sempre que possível, restaurar a vítima na condição original antes da grave violação de direitos humanos ou grave violação ao direito internacional humanitário. A restituição inclui, quando apropriado, a restauração da liberdade, o gozo dos direitos humanos, identidade, vida familiar e cidadania, retorno ao local de residência, restauração do emprego e retorno da propriedade.

A compensação deve ser provida para qualquer dano economicamente mensurável, adequada e proporcionalmente ao dano sofrido, que pode ser um sofrimento físico e mental; a perda de oportunidades, inclusive de emprego, educação e benefícios sociais; danos materiais e lucros cessantes; danos morais; custas legais ou assistência médica, hospitalar, psicológica ou social.

A reabilitação deve incluir cuidados médicos e psicológicos, assim como serviços social e jurídico.

A satisfação deve incluir, quando aplicável, medidas efetivas para cessar a continuidade da violação; verificar os fatos e a verdade sobre as violações, desde que não cause mais danos ou ameaça à segurança e interesses das vítimas, familiares e testemunhas; investigar desaparecimentos e a identidade de vítimas; declaração pública oficial ou decisão judicial que restaure a dignidade e reputação das vítimas e seus direitos; 
pedido público de desculpas, inclusive com o conhecimento dos fatos e reconhecimento da responsabilidade; sanções administrativas e judiciais; dentre outras medidas.

A garantia de não-repetição deve incluir, quando aplicável, toda e qualquer das seguintes medidas, que também contribuem com a prevenção de outras violações: assegurar o efetivo controle civil das forças militares e forças de segurança; assegurar que todos os procedimentos civis e militares sejam compatíveis com os parâmetros internacionais de devido processo, imparcialidade e justiça; fortalecer a independência do judiciário; proteger pessoas em profissões legais, médicas e cuidados de saúde, de mídia e outros profissionais e os defensores de direitos humanos; promover, como prioridade e de forma continuada, educação em direitos humanos e em direito internacional humanitário a todos os setores da sociedade e treinamento para os profissionais de segurança, militares e forças armadas; promover a observância de códigos de conduta e ética, nos parâmetros internacionais, de todos os servidores públicos e empresas privadas; promover mecanismos para prevenção e monitoramento de conflitos sociais e suas resoluções; rever e reformar a legislação que contribua ou permita graves violações de direitos humanos e direito internacional humanitário.

(c) Por fim, os Estados devem promover o acesso a informação relevante sobre a violação e mecanismos de reparação a todos, especialmente às vítimas de graves violações sobre seus direitos e medidas aplicáveis indicadas nos Princípios e Diretrizes Básicos sobre o Direito das Vítimas de Violações das Normas Internacionais de Direitos Humanos e do Direito Internacional Humanitário a Interpor Recursos e Obter Reparações (Resolução 60/147) e em todos os serviços disponíveis jurídicos, médicos, psicológicos, sociais, administrativos e todos os serviços que a vítima tenha o direito de acessar.

Vale ressaltar que a interpretação dessa normativa deve ser feita sem nenhuma forma de discriminação e sua aplicação não deve restringir ou derrogar nenhuma outra obrigação que promova maior proteção à vítima.

\subsection{Breves apontamentos sobre a reparação às vítimas no Brasil}

A reparação abrange não apenas a compensação financeira dos danos sofridos, mas também a restauração da liberdade e direitos fundamentais, a reabilitação por meio de cuidados médicos, psicológicos, social e jurídico; a satisfação e garantia de não-repetição conforme o disposto nos Princípios e Diretrizes Básicos sobre o Direito das Vítimas de 
Violações das Normas Internacionais de Direitos Humanos e do Direito Internacional Humanitário a Interpor Recursos e Obter Reparações (Resolução 60/147).

A completa e efetiva reparação é pouco conhecida e aplicada. A atuação do governo brasileiro não tem privilegiado igualmente todos os aspectos da reparação. $O$ ressarcimento financeiro é, geralmente, uma das primeiras medidas adotadas pelo Brasil no cumprimento de sentenças e decisões internacionais. A indenização pecuniária foi uma das primeiras medidas tomadas em relação ao acidente aéreo nas proximidades do aeroporto de Congonhas em São Paulo em 1992; ou o "buraco do metrô" no início de 2007; ou acidente no aeroporto de congonhas em 2007, dentre outros. Com a indenização paga, as pessoas atingidas, direta ou indiretamente pelos fatos, continuam a sofrer o impacto e conseqüências do ocorrido - seja pela perda de bens, seja pela necessidade de arcar com prejuízos decorrentes dos danos sofridos, seja pela perda do ente querido, seja pela necessidade de cuidados médicos, dentre outras necessidades. Não se nega a importância da indenização pecuniária, mas ela representa apenas um dos aspectos da reparação, pois não restitui a situação anterior aos fatos, nem reabilita a vítima e sequer impede a ocorrência de episódios semelhantes no futuro.

$\mathrm{O}$ atendimento às vítimas (reabilitação nos termos da Resolução) ainda é pouco conhecido, divulgado e investido. Algumas unidades federativas dispõem de alguns serviços de atendimento a determinadas vítimas, mas não se verifica uma política consolidada que inclua os aspectos de restituição da condição anterior à violação; de compensação financeira pelos danos sofridos; de reabilitação médica, social, psicológica e jurídica; de satisfação pelo fim da continuidade da violação; e a prevenção de outras violações.

A título de exemplificação, ressalta-se que o programa federal de assistência e proteção a vítimas não se encontra implementado em todos os estados da federação ${ }^{32}$. Há diferentes estruturas de apoio e assistência às vítimas, conforme seu perfil: Disque Denúncia Nacional em relação ao combate ao abuso e exploração sexual contra crianças e adolescentes; Centro de Referência em relação ao programa de combate à homofobia; Centro de Apoio à Prevenção e Enfrentamento à violência contra idosos; Comissão

\footnotetext{
${ }^{32}$ Em breve pesquisa no site da Secretaria Especial de Direitos Humanos, verifica-se que o programa de assistência a vítimas encontra-se incluído, discretamente, no Sistema Nacional de Assistência a Vítimas e Testemunhas Ameaçadas, que trata do serviço de proteção a testemunhas ameaçadas. Sabe-se que há financiamento federal em programas de assistência às vítima, independentemente de sua condição de testemunha em processo penal ou de ameaça, no estado de São Paulo (CRAVI) e em Minhas Gerais (NAVCV). Foi consultado o site da Secretaria Especial de Direitos Humanos (disponível em: http://www.presidencia.gov.br/estrutura_presidencia/sedh/) em 25/01/08.
} 
Permanente de Combate à Tortura e à Violência Institucional, dentre outros. Os pedidos de indenizações civis ficam a cargo das vítimas, que nem sempre recorrem a tais medidas. Algumas indenizações são realizadas administrativamente em casos pontuais, geralmente quando há repercussão na mídia e/ou decisão internacional proferida por órgãos de monitoramento de direitos humanos ${ }^{33}$.

No Brasil, observa-se que a atenção às vítimas de violência é tratada geralmente com base na proteção em casos de grave ameaça à vida ou com base na assistência às vítimas. A proteção às vítimas ameaçadas geralmente é oferecida nos casos em que há um procedimento oficial ${ }^{34}$ e a vítima é atendida na condição de testemunha. Em relação à assistência às vítimas ${ }^{35}$, o atendimento é prestado geralmente por equipe multidisciplinar em centros de apoio, de acordo com o perfil da vitimização - por exemplo, em relação a mulher vítima de violência, criança e adolescente, idosos, etc.

\subsection{Breve análise da legislação sobre vítima no Brasil}

No plano nacional, a reparação nos termos dessa Resolução 60/147 é pouco conhecida e desenvolvida. No Brasil não há um arcabouço legal adequado para proteção dos direitos das vítimas, na medida em que não há sequer uma legislação nacional sobre a política de assistência e apoio à vítima, ou uma política pública efetiva e permanente de reparação às vítimas, especialmente em relação à reabilitação e garantia de não-repetição, como forma de prevenção de futuras violências.

\footnotetext{
${ }^{33}$ Por exemplo, no caso Damião Ximenes Lopes em que o Brasil foi condenado pela primeira vez pela Corte Interamericana de Direitos Humanos, em julho de 2006, em decorrência de maus-tratos e violência sofridos por Damião Ximenes Lopes, portador de transtorno mental, falecido após três dias de sua internação em clínica psiquiátrica no Ceará. Em agosto de 2007, o Governo Brasileiro pagou indenização no valor de R\$ 250 mil aos familiares da vítima. Vale ressaltar que a sentença da Corte determinou também, além do pagamento em dinheiro aos familiares da vítima a título de indenização por dano material e imaterial, ao Estado Brasileiro: garantir, em prazo razoável, que o processo interno destinado a investigar e sancionar os responsáveis pelos fatos desse caso surta seus devidos efeitos; publicar, no prazo de seis meses, o capítulo VII relativo aos fatos provados da sentença da corte; continuar a desenvolver um programa de formação e capacitação para o pessoal médico, de psiquiatria e psicologia, de enfermagem e auxiliares de enfermagem e para todas as pessoas vinculadas ao atendimento de saúde mental, em especial sobre os princípios que devem reger o trato das pessoas com deficiência mental, conforme os padrões internacionais sobre a matéria e os dipostos na sentença; e o pagamento em dinheiro a título de custas e gastos gerados no âmbito interno e internacional perante o sistema interamericano de direitos humanos.

${ }^{34} \mathrm{O}$ requisito da denúncia formal ou da existência de um inquérito ou processo penal ocorre principalmente em relação aos programas de proteção de vítimas e testemunhas ameaçados que atendem um público em geral. Os programas de proteção a crianças e adolescentes ameaçados de morte não apresentam, em geral, esse requisito para o atendimento.

${ }^{35}$ Ver Parte II sobre Atendimento às vítimas de violência no Brasil.
} 
Em pesquisa realizada no website do Senado Federal ${ }^{36}$, foram localizados 4005 documentos sobre "vítima", dos quais 119 referiam-se a legislação federal e 273 a matérias em tramitação no Senado, das quais 92 eram projetos de lei da Câmara e 109 projetos de lei do Senado e uma Proposta de Emenda Constitucional ${ }^{37}$.

A Proposta de Emenda Constitucional n. 05 de $2007^{38}$ prevê a criação de um Fundo de Combate à Violência e Apoio às Vítimas da Criminalidade. De acordo com essa proposta, haveria um acréscimo de artigos 95 a 98 no Ato das Disposições Constitucionais Transitórias, com a criação do mencionado fundo e a previsão de um Conselho Consultivo e de Acompanhamento a ser definido em lei complementar, garantindo-se a participação de representante da sociedade civil. De acordo com a PEC n. 5 de 2003, esse Fundo de Combate à Violência e Apoio às Vítimas da Criminalidade teria como objetivos: "viabilizar ações preventivas que garantam à população acesso a níveis dignos de segurança pública; garantir recursos para o apoio emergencial e permanente aos agentes do Poder Público, direta ou indiretamente envolvidos no combate à criminalidade e na defesa da sociedade civil; e às vítimas da violência".

As ações preventivas incluiriam a criação e manutenção de cursos especiais de formação e especialização de agentes públicos da área de segurança pública e "outros programas de relevante interesse social, voltados à garantia da segurança pública e à valorização dos profissionais da área”. O apoio emergencial e permanente proposto incluiria a criação e manutenção de programas de habitação, saúde, educação, complementação de renda e amparo social, em benefício dos servidores e militares da área de segurança pública e das vítimas da criminalidade, bem como de suas famílias, quando desamparadas. Há ainda a previsão de criação de fundos estaduais e municipais.

Tal Fundo de Combate à Violência e Apoio às Vítimas da Criminalidade, previsto nessa Proposta de Emenda Constitucional, parece atender mais os interesses de agentes públicos da área de segurança pública que aos interesses das vítimas da criminalidade

\footnotetext{
$\overline{36}$ De acordo com: http://www6.senado.gov.br/pesquisa/preparaPesquisaBasica.action?argumento $=\mathrm{v} \%$ EDtima\&executa $=\mathrm{s}$ (acesso em 24/01/08)

37 Refinando-se a pesquisa para "vítima" e "violência", foram localizados 1 Proposta de Emenda Constitucional, 16 Projetos de lei propostos pela Câmara dos Deputados e 15 projetos de lei propostos pelo Senado Federal em tramitação.

${ }^{38}$ Proposta de Emenda Constitucional n. 05 de 2007, de autoria do Senador Antonio Carlos Magalhães, cria Fundo de Combate à Violência e Apoio às Vítimas da Criminalidade. Tramitação da PEC disponível em: http://www.senado.gov.br/sf/atividade/Materia/Detalhes.asp?p_cod_mate=79919 (acesso em 24/01/08).
} 
indistintamente consideradas - visto que há uma inclusão expressa desses servidores nos benefícios previstos.

Dentre os Projetos de Lei em tramitação no Senado, vale destacar o Projeto de Lei do Senado n. 269 de $2003^{39}$, que define os direitos das vítimas de ações criminosas e regulamenta o artigo 245 da Constituição Federal, para criar o Fundo Nacional de Assistência às Vítimas de Crimes Violentos (FUNAV), além de outras providências. Esse projeto de lei considera vítima "a pessoa que suporta direta ou indiretamente os efeitos da ação criminosa consumada ou tentada, vindo a sofrer danos físicos, psicológicos, morais ou patrimoniais, ou quaisquer outras violações de seus direitos fundamentais, bem como os familiares próximos".

Os direitos das vítimas previstos não abrangem algumas medidas de reparação, como a reabilitação por meio de cuidados médicos, psicológicos, sociais e jurídicos; nem medidas de não-repetição e conseqüente prevenção da violência. Verifica-se também, nesse projeto de lei, uma ênfase em medidas de caráter individual - com a previsão de assistência financeira para gastos funerários, tratamento e despesas médicas decorrentes da violência - mas com pouca ênfase ou estímulo a medidas coletivas de apoio e prevenção, como um atendimento em centros de referência, ou adoção de medidas para cessar a continuação de violações, dentre outras medidas que poderiam favorecer um debate público ou ação coletiva.

Há também nesse projeto de lei a previsão de criação de um Fundo Nacional de Assistência às Vítimas de Crimes Violentos (FUNAV), com a finalidade de "proporcionar recursos e meios para a prestação de assistência financeira às vítimas de crimes violentos ou a seus herdeiros e dependentes carentes". Os recursos desse fundo seriam aplicados exclusivamente para assistência financeira, paga em quantia única, em casos de alguns crimes dolosos praticados em território nacional: homicídio (artigo 121 do Código Penal), lesão corporal de natureza grave de que resulta debilidade permanente de membro, sentido ou função, incapacidade permanente para o trabalho, enfermidade incurável ou perda ou inutilização de membro, sentido ou função (artigo 129, § $1^{\circ}$, III e $\S 2^{\circ}$, I, II e III, do Código Penal); crime contra a liberdade sexual cometido mediante violência ou grave ameaça (artigos 213 e 214 do Código Penal) e de homicídio ou lesão corporal de natureza grave

\footnotetext{
${ }^{39}$ Projeto de Lei do Senado n. 269 de 2003, de autoria do senador José Sarney (PMDB/AP), define os direitos das vítimas de ações criminosas e regulamenta o artigo 245 da Constituição Federal, para criar o Fundo Nacional de Assistência às Vítimas de Crimes Violentos (FUNAV), além de outras providências. Tramitação disponível em: http://www.senado.gov.br/sf/atividade/Materia/Detalhes.asp?p_cod_mate=59360 (acesso em 25/01/08).
} 
provocados por projétil de arma de fogo, quando ignorado o autor e as circunstancias do disparo, ainda que inexista dolo.

A ênfase na assistência exclusivamente financeira desse projeto de lei representa uma proposta diante da violência. $\mathrm{O}$ aspecto financeiro, embora importante, não é a única forma de reparação, conforme já mencionado anteriormente. Também são relevantes os cuidados médicos, psicológicos, sociais e jurídicos; a investigação e punição dos responsáveis pela violação; assim como a prevenção de futuros casos semelhantes.

A legislação federal brasileira se refere à vítima em medidas legislativas que concedem indenização ou pensão por acidente de trabalho sofrida por funcionários públicos, decretos que declaram luto oficial, leis que instituem dia nacional para conscientização de determinada violência ou em memória de vítimas, leis que criam tipos penais específicos para determinada forma de violência, leis que aumentam a pena em razão da vítima envolvida ${ }^{40}$. Entretanto, medidas legislativas pouco se referem aos direitos da vítima em geral (a maioria dos documentos analisados concedem benefícios às vítimas de determinado acidente ou fato, individualmente consideradas após o incidente).

A participação das vítimas nos procedimentos judiciais no Brasil não é constante e regulamentado. No processo penal, há a possibilidade de a vítima habilitar-se como assistente de acusação por meio de um advogado. Essa forma de participação é pouco utilizada $^{41}$ e geralmente ocorre em fase processual, após a manifestação do promotor público. Em fase de investigações dos fatos, a participação da vítima do suposto crime é condicionada à "boa vontade" do delegado de polícia ou do promotor público, na medida em que as informações sobre o curso da investigação são mantidas nos autos do inquérito policial e raramente passadas às vítimas - as quais precisam ligar constantemente para obter tais informações.

A legislação brasileira não se mostra adequada para garantir o exercício dos direitos da vítima, especialmente quanto à participação, proteção e reparação. A proteção da vítima geralmente é concedida quando ela é testemunha em procedimento judicial, o que a

\footnotetext{
${ }^{40} \mathrm{Em}$ pesquisa no site do Senado Federal, foram localizados 122 documentos que se referem ao termo vítima, dos quais: 39 são leis ordinárias, 24 decretos lei, 1 lei complementar, 1 decreto do Conselho de Ministro e 57 decretos. Somente ente as Leis Ordinárias foi verificada alguma referência ao atendimento às vitimas ou quanto a outros direitos. Em geral, as leis ordinárias se referem a aumento de pena conforme a vítima do crime, política de assistência e proteção a vítimas e testemunhas ameaçadas etc. De acordo com: http://www6.senado.gov.br/pesquisa/selecionaTipoDocumento.action?id=20090130043932118\&codigoBase $=2 \&$ codigos TiposDocs $=26$ (acesso em 29/01/09)

${ }^{41}$ Não abordaremos a discussão sobre eventual adequação desse instituto na defesa dos direitos humanos. Apenas mencionamos a possibilidade prevista na legislação processual penal.
} 
privilegia na condição de testemunha; as vítimas que correm riscos ou ameaças de morte, mas que não comprovam os fatos analisados num procedimento judicial dificilmente conseguirão uma inserção em programas de proteção. A completa e efetiva reparação é quase desconhecida, inclusive nos meios jurídicos. A participação da vítima no processo carece de instrumentos que a viabilizem.

A vítima é tratada geralmente de forma individualizada e após a ocorrência do fato. No âmbito penal, considerada para a fixação da pena do acusado. No âmbito cível, a reparação é compreendida apenas no seu aspecto compensatório, na figura da indenização. As medidas legislativas se mostram inadequadas ao efetivo exercício dos direitos das vítimas. 


\section{Capitulo 2: DIREITOS HUMANOS E VÍTIMAS DE VIOLÊNCIA}

Nesse capítulo serão debatidos os principais desafios da concepção contemporânea de direitos humanos e apresentadas algumas experiências de promoção dos direitos das vítimas no sistema internacional (global e regional) de proteção dos direitos humanos. Não será desenvolvido um estudo aprofundado sobre a teoria geral dos direitos humanos e os sistemas de proteção. Apresentaremos um panorama do tema e algumas questões relacionadas às vítimas de violência.

Os direitos humanos baseiam-se no reconhecimento da condição de humanidade a todo e qualquer ser humano, pela sua dignidade, independentemente de sexo, cor, etnia, condição social, religião, etc. Como salienta Bobbio: "Os direitos humanos não nascem todos de uma vez. Nascem quando devem ou podem nascer" ${ }^{42}$. Tais direitos são frutos de um processo histórico, de uma construção e reconstrução humana. No mesmo sentido, Celso Lafer $^{43}$, lembrando Danièle Lochak, destaca que a história dos direitos humanos não é nem a história de uma marcha triunfal nem a história de uma causa perdida de antemão; mas a história de um combate.

$\mathrm{O}$ aspecto histórico ${ }^{44}$ dos direitos humanos pode ser analisada a partir de três fases classificadas por Bobbio: numa $1^{\mathrm{a}}$ fase, os direitos humanos eram entendidos como direitos naturais universais, sob ótica jusnaturalista, com a possibilidade de diversas fundamentações (de cunho religioso, de origem na natureza humana, fundamento racional, dentre outros). A fonte histórica desse período seria o iluminismo e a base jusnaturalista racional, com Rousseau, Locke e Montesquieu, como expoentes.

Numa $2^{\mathrm{a}}$ fase, os direitos humanos eram compreendidos como direitos positivos particulares, com o constitucionalismo como pano de fundo (final século XIX). Com as Constituições, os direitos ganham positivações (com a finalidade de proteger os direitos e limitar o arbítrio do Estado); mas perdem alcance, já que se limitam ao território do Estado, não mais a uma universalidade baseada na natureza.

\footnotetext{
${ }^{42}$ Norberto Bobbio, A era dos direitos, Rio de Janeiro, Campus, 1992, p. 6.

${ }^{43}$ Celso Lafer, prefácio ao livro Direitos Humanos e Justiça Internacional, Flávia Piovesan, São Paulo, Saraiva, 2006, p. XXII.

${ }^{44}$ Para aprofundamento, verificar Fabio Konder Comparato, A afirmação histórica dos direitos humanos, Editora Saraiva; José Damião de Lima Trindade, "Anotações sobre a história social dos direitos humanos", in: Direitos Humanos: construção da liberdade e da igualdade, Centro de Estudos da Procuradoria Geral do Estado, 2000, p.21-163; dentre outros.
} 
Após a II Guerra Mundial, em resposta aos horrores perpetrados, a comunidade internacional afirma a preocupação com os rumos da humanidade e 48 Estados, em acordo, firmam a Declaração Universal dos Direitos Humanos em 1948, caracterizando a $3^{\mathrm{a}}$ fase: dos direitos positivados universais.

A Declaração Universal dos Direitos Humanos de 1948 expressa uma concepção contemporânea de direitos humanos, a qual consagra a sua universalidade: todas as pessoas têm direitos, tendo como fundamento a dignidade humana. Em outras palavras, para a titularidade de tais direitos, o único requisito é a condição de pessoa, de ser humano. Por direitos humanos, entende-se todos aqueles necessários para a plena realização e desenvolvimento da condição de dignidade da pessoa humana: os direitos civis e políticos, os direitos econômicos, sociais e culturais, e os direitos de solidariedade. A Declaração Universal dos Direitos Humanos busca esforços para uma composição entre as agendas das diferentes dimensões dos direitos humanos: direitos civis e políticos na mesma posição que os direitos econômicos, sociais e culturais, visto que um depende do outro, um é condição para respeito e exercício do outro. Ressalte-se ainda a progressividade dos direitos humanos: os direitos humanos devem ser progressivamente implementados e jamais retrocederem (princípio da proibição de retrocesso social). Vale ressaltar que a Declaração Universal de Direitos Humanos reflete o seu tempo e não prevê os direitos de solidariedade, como direito ao meio ambiente saudável e equilibrado, direito à autodeterminação do povos, direito ao desenvolvimento, dentre outros direitos numa lógica de proteção não apenas dos seres humanos do presente, mas também das futuras gerações.

$\mathrm{Na}$ concepção contemporânea, os direitos humanos são indivisíveis, interdependentes e inter-relacionados; ou seja, o exercício dos direitos civis e políticos depende do pleno exercício dos direitos econômicos, sociais e culturais e direitos de solidariedade, numa visão integral dos direitos humanos.

A Declaração e Programa de Ação de Viena, adotada pela Conferência Mundial de Direitos Humanos, realizada em Viena, em 1993, consenso entre 171 Estados, endossa a indivisibilidade, interdependência e inter-relação entre os direitos humanos e afirma a relação indissociável entre direitos humanos, democracia e desenvolvimento.

A proteção dos direitos humanos deve conjugar o âmbito local, regional e global. No âmbito global, há a normativa da Organização das Nações Unidas (ONU). Destacam-se os Pactos Internacionais de Direitos Civis e Políticos e de Direitos Econômicos, Sociais e Culturais e os tratados internacionais de proteção especial - como a Convenção contra a 
Tortura e outros tratametos ou penas cruéis, desumanos ou degradantes, Convenção sobre a Eliminação de todas as formas de discriminação racial, Convenção sobre a Eliminação de todas as formas de discriminação contra a mulher, Convenção sobre os Direitos da Criança.

No plano regional, destaca-se o sistema interamericano de proteção dos direitos humanos, com destaque à Comissão Interamericana de Direitos Humanos e a Corte Interamericana. Os principais instrumentos do sistema regional interamericano são: aConvenção Americana de Direitos Humanos, Protocolo Adicional à Convenção Americana de Direitos Humanos em matéria de Direitos Econômicos, Sociais e Culturais, Convenção Interamericana para Prevenir e Punir a Tortura e a Convenção Interamericana para Prevenir, Punir e Erradicar a violência contra a mulher.

O plano local de proteção aos direitos humanos se refere a todas as medidas adotadas para respeito, proteção e implementação dos direitos humanos no âmbito nacional ou local.

Muitos desafios se impõem à concretização da concepção contemporânea de direitos humanos. Embora a indivisibilidade dos direitos humanos tenha sido reforçada na Declaração e Programa de Ação de Viena, adotada em 1993 pela Conferência Mundial de Direitos Humanos da ONU, ainda persiste certa tensão entre os direitos civis e políticos e os direitos econômicos, sociais e culturais, assim como entre o discurso dos países do hemisfério norte (desenvolvidos) e os direitos reivindicados do sul (países em desenvolvimento). O desafio também se coloca em relação à ótica individualista (caracterizada pelos direitos civis e políticos) em oposição à ótica coletiva dos direitos econômicos, sociais e culturais ${ }^{45}$. E da responsabilidade dos atores não estatais: organizações não governamentais, mas principalmente grandes empresas multinacionais. ${ }^{46}$

Diante de tamanhos desafios, a visão integral dos direitos humanos se mostra ainda mais importante para o desenvolvimento e a democracia, num cenário em que a dignidade humana deve ser respeitada e os direitos humanos devem ser aperfeiçoados em seu caráter indivisível, interdependente e inter-relacionado, progressivamente garantidos.

\footnotetext{
${ }^{45}$ Vale destacar que os direitos civis e políticos são geralmente vistos numa ótica individual, embora também possam ser tratados de forma coletiva - exemplo: voto e democracia exigem um senso coletivo.

${ }^{46}$ Todos esses desafios têm com o pano de fundo outro desafio: do unilateralismo em oposição ao multilateralismo, em especial pós 11 de setembro.
} 
Um dos maiores desafios ${ }^{47}$ da concepção contemporânea dos direitos humanos é a superação da tensão entre universalismo e relativismo cultural. Em outras palavras, questiona-se se os direitos humanos valem para toda e qualquer sociedade, independentemente da cultura local. Há que se ressaltar a oposição entre o universalismo e relativismo cultural. O primeiro tem como fonte principal dos direitos humanos a dignidade humana como valor intrínseco, desconsiderando qualquer influência cultural. Ao passo que o segundo tem como fundamento a cultura local, contrapondo-se à uma idéia universal de um mínimo ético irredutível de dignidade humana. Questiona-se também a ocidentalização da concepção de direitos humanos e o estranhamento entre as culturas.

Na perspectiva apresentada por Jack Donnelly ${ }^{48}$, discutida por Daniela Ikawa ${ }^{49}$, há uma escala de gradações entre universalismo radical e relativismo radical nos extremos. Para o relativista radical, os direitos humanos não se aplicam para todos indistintamente, pois dependem da cultura e não há uma concepção única de direitos humanos para toda humanidade. Tudo é relativo e depende da cultura inserida. Para o universalista, existe um mínimo ético irredutível da dignidade humana, cujo alcance permitirá maior ou menor possibilidade para uma discussão cultural. O universalista radical tem mínimo ético irredutível com grande alcance, não permitindo um diálogo com outras culturas. Para o universalista radical, os direitos humanos são os mesmos para toda a humanidade, independentemente dos valores culturais locais de uma população.

Intermediariamente a esses dois pólos mencionados, há o universalismo forte e universalismo fraco ${ }^{50}$. Partindo-se do pressuposto de um mínimo ético irredutível, o universalista forte dá mais espaço para a diversidade cultural que o universalista radical, mas ainda mantém forte influência do mínimo ético; para ele, a principal fonte de validade moral e o principal fundamento do direito é o valor intrínseco ao homem, com reduzida discussão sobre aspectos culturais. O universalista fraco permite maior diálogo com a diversidade cultural e seu mínimo ético tem menor alcance; pois reconhece tanto um valor intrínseco como a cultura como fundamento do direito e fonte de validade moral. $\mathrm{O}$

\footnotetext{
${ }^{47}$ Flavia Piovesan, Direitos Humanos e Justiça Internacional,São Paulo, Ed. Saraiva, 2006, p.7-32.

${ }^{48}$ Conforme Jack Donnelly, "Universal Human Rights in theory and practice", 2a ed., Ithaca, NY: Cornell University Press, 2003, p. 109-124.

49 Daniela Ikawa, "Universalismo, relativismo e direitos humanos", in: Maria de Fátima Ribeiro (org.), Direito Internacional dos Direitos Humanos: estudos em homenagem à Profa. Flávia Piovesan, Curitiba, Juruá, 2004, pp. 117-126.

${ }^{50}$ Donelly indica relativismo forte e relativismo fraco entre o relativismo radical e o universalismo radical; ao passo que Ikawa aponta para o universalismo forte e o universalismo fraco, tomando como princípio que o universalista parte de um mínimo ético irredutível que pode ser de maior ou menor alcance. Neste trabalho, adota-se essa segunda visão.
} 
universalista fraco considera que há determinados elementos comuns a toda humanidade (mínimo ético irredutível), mas pode adotar a cultura como elemento caracterizador do homem, do direito e da moral; considerando uma cultura aberta ao diálogo com outras culturas.

Nesse sentido, o universalista radical apresenta um canal bastante estreito (e quase nulo) ao diálogo com outras culturas, com um rol extenso de direitos humanos comuns a todos, independentemente da cultura local; ao passo que para o relativista radical, a cultura condiciona o elenco dos direitos humanos e, em última instância, nega a existência de algum consenso entre as diferentes culturas. Ambas posições extremas parecem não conciliar diferenças e igualdades, de forma que as posições intermediárias (universalista forte ou universalista fraco) tendem a possibilitar o diálogo entre as culturas e maior alcance dos direitos humanos.

Diante da diversidade de culturas - no mundo e no interior de um mesmo Estado, culturas que se interinfluenciam ${ }^{51}$ dentro e além do próprio Estado - e do reconhecimento da incompletude dessas culturas, há que se fortalecer e investir no diálogo intercultural, numa concepção multicultural dos direitos humanos de caráter emancipatório ${ }^{52}$.

Boaventura de Sousa Santos aponta cinco teses sobre multiculturalismo emancipatório e escalas de lutas contra a dominação: i) diferentes coletivos humanos produzem formas diversas de ver e dividir o mundo de forma não necessariamente eurocêntrica; ii) diferentes formas de opressão ou dominação geram formas de resistência, mobilização, subjetividade e identidades coletivas também distintas, que invocam diferentes noções de justiça; iii) incompletude das culturas e das concepções de dignidade humana, direito e Justiça exigem o desenvolvimento de formas de diálogo que promovam a ampliação da reciprocidade; iv) políticas emancipatórias e invenção de novas cidadanias jogam-se no terreno da tensão entre igualdade e diferença, entre exigência de reconhecimento e imperativo da redistribuição; v) o sucesso das lutas emancipatórias

\footnotetext{
${ }^{51}$ Estudos e relatos indicam as dificuldades de composição entre diferentes culturas e o estranhamento vivido pelo sujeito que se insere numa cultura com sua bagagem cultural, ou retorna para a cultura materna com outra bagagem. Nesse sentido, a obra de Todorov, $O$ homem desenraizado, ilustra com propriedade esse estranhamento vivido diante das diferenças culturais.

${ }^{52}$ Vide Boaventura de Sousa Santos, Por uma concepção multicultural de direitos humanos, in: Reconhecer para Libertar: os caminhos do cosmopolitismo multicultural, Rio de Janeiro, Civilização Brasileira, 2003,p. 427-461.
} 
depende das alianças que seus protagonistas forem capazes de forjar. (Introdução: para ampliar o cânone do reconhecimento, da diferença e da igualdade. ${ }^{53}$

Dentre essas teses, destaca-se a tese de que a incompletude das culturas e das concepções de dignidade humana, direito e Justiça exige o desenvolvimento de formas de diálogo que promovam a ampliação do círculo de reciprocidade; a tese de que políticas emancipatórias e invenção de novas cidadanias jogam-se no terreno da tensão entre igualdade e diferença, entre exigência de reconhecimento e imperativo da redistribuição; e a tese de que o sucesso das lutas emancipatórias depende das alianças que seus protagonistas forem capazes de forjar.

Nesse sentido, a cultura ou multiculturalismo podem ser recursos estratégicos para políticas emancipatórias de exigência do reconhecimento da diferença e de afirmação do imperativo do diálogo. Quanto maior o grau de reciprocidade (em especial no tocante à concepção de direito e Justiça), maior será a capacidade de inclusão de atores e de diálogo. O diálogo e as alianças construídas pelos protagonistas podem se mostrar essenciais para o sucesso de lutas emancipatórias.

Entretanto, a afirmação da igualdade, em última instância, pode conduzir a uma descaracterização e negação da identidade; e a afirmação da diferença por si pode gerar discriminação, exclusão ou inferiorização. Assim, é fundamental a composição entre o princípio da igualdade e o princípio da diferença. Boaventura de Sousa Santos ressalta que a defesa da igualdade deve ser evocada sempre que a diferença gerar inferioridade, e a diferença deve prevalecer quando a igualdade implicar em descaracterização. $O$ multiculturalismo pode ser um recurso estratégico do reconhecimento da diferença e afirmação do imperativo do diálogo.

Uma política emancipatória de direitos humanos deve saber distinguir entre a luta pela igualdade e a luta pelo reconhecimento igualitário da diferença. A mobilização pessoal e social para as possibilidades e exigências emancipatórias dos direitos humanos e da dignidade humana só será concretizável na medida em que tais possibilidades e exigências forem apropriadas e apreendidas pelo contexto cultural local; jamais será eficaz se baseada em imposição cultural ou "canibalismo cultural". 54

\footnotetext{
53 Boaventura de Sousa Santos, Reconhecer para Libertar: os caminhos do cosmopolitismo multicultural. Rio de Janeiro: Civilização Brasileira, 2003, p. 60-66.

${ }^{54}$ Boaventura de Souza Santos, obra citada.
} 
Os direitos humanos têm o potencial emancipatório se for transformado em discurso e prática de localismo globalizado para um projeto cosmopolita ${ }^{55}$. O projeto cosmopolita pressupõe uma solidariedade transnacional entre grupos explorados, oprimidos ou excluídos pela globalização hegemônica, um cosmopolitismo do subalterno em luta contra sua subalternização.

Outra premissa da transformação cosmopolita dos direitos humanos é que todas as culturas têm concepções de dignidade humana, mas nem todas são concebidas como direitos humanos; as culturas têm versão diferente de dignidade humana, algumas mais amplas, outras com reciprocidade maior ou menor, mais ou menos abertas a outras culturas. Todas culturas são incompletas e problemáticas nas concepções de dignidade humana; a incompletude decorre da ausência de uma única cultura e, portanto, da própria existência de uma pluralidade de culturas. Todas as culturas tendem a distribuir pessoas ou grupos sociais entre princípio de igualdade e princípio da diferença. Uma política emancipatória de direitos humanos deve saber distinguir entre a luta pela igualdade e a luta pelo reconhecimento igualitário da diferença, a fim de travar ambas lutas eficazmente.

Num diálogo intercultural, a troca não é apenas entre diferentes saberes, mas também entre diferentes culturas, entre universos de sentido diferentes. Nesse sentido, muitas vezes faz-se necessário explicar ou justificar idéias e ações que na nossa cultura são evidentes e do senso-comum. A mobilização pessoal e social para as possibilidades e exigências emancipatórias dos direitos humanos e da dignidade humana só será concretizável na medida em que tais possibilidades e exigências forem apropriadas e absorvidas pelo contexto cultural local. A luta pelos direitos humanos e dignidade humana jamais será eficaz se baseada em imposição cultural.

A hermenêutica diatópica ${ }^{56}$ baseia-se na interpretação e diálogo a partir da noção de

\footnotetext{
55 Boaventura de Sousa Santos considera quatro modos de globalização: localismo globalizado, em que determinado fenômeno local é globalizado com sucesso; globalismo localizado, no qual condições locais sofrem impacto de práticas transnacionais, em geral desestruturando-se e reestruturando-se de forma a responder aos imperativos transnacionais; cosmopolitismo, que se refere a um conjunto vasto e heterogêneo de iniciativas, movimentos e organizações que partilham a luta contra exclusão e discriminação sociais e destruição ambiental produzidas pela globalização hegemônica; e patrimônio comum da humanidade, composto por temas globais que só fazem sentido em relação ao próprio planeta na sua totalidade. Os dois primeiros se referem formas de globalização de cima para baixo, ao passo que os dois últimos são formas de globalização contra-hegemônica, de baixo para cima. (Reconhecer para libertar: os caminhos do cosmopolitismo multicultural, Rio de Janeiro, Civilização Brasileira, 2003, p. 433-438.)

${ }^{56}$ ver Boaventura de Sousa Santos, Reconhecer para libertar: os caminhos do cosmopolitismo multicultural, Rio de Janeiro, Civilização Brasileira, 2003, p. 443-451; e Raimundo Panikkar, É a noção dos direitos do homem um conceito ocidental? In: Diógenes: Revista Internacional de Ciências Humanas n ${ }^{\circ}$ 05, UnB, 1983, pp.5-29.
} 
que os $t o p o i^{57}$ de uma determinada cultura, por mais forte que sejam, são incompletos como a própria cultura a que pertencem. Não se tem como objetivo atingir a completude (que é inatingível), mas ampliar o máximo de consciência da incompletude mútua por meio do diálogo que se desenrola com um pé em cada cultura.

O reconhecimento de incompletudes mútuas é condição sine qua non de um diálogo intercultural. A hermenêutica diatópica é um trabalho de colaboração intercultural e não pode ser levado a cabo a partir de uma única cultura ou por uma só pessoa; exige um diferente processo de criação de conhecimento. A produção de conhecimento deve ser coletiva, participativa, interativa, intersubjetiva e reticular, baseada em trocas cognitivas e afetivas que avançam por intermédio do aprofundamento de reciprocidade entre as culturas; de forma a favorecer o conhecimento-emancipação em detrimento do conhecimento-regulação ${ }^{58}$.

O caráter emancipatório da hermenêutica diatópica não está garantido por si, de forma que o multiculturalismo pode se tornar um novo rótulo de uma política reacionária. Os diálogos interculturais devem ser baseados em condições estabelecidas por mútuo acordo, tomando-se o devido cuidado com o risco de fechamento cultural ou de conquista cultural. Para um multiculturalismo progressista é preciso que o princípio da igualdade seja conjugado com o princípio da diferença, de forma que seja respeitado o direito a ser igual quando a diferença inferioriza e o direito a ser diferente quando a igualdade descaracteriza.

\subsection{Breves apontamentos sobre direitos humanos e atendimento à vítima}

Grande parte das ocorrências de homicídios praticados são arquivadas em fase de inquérito policial por não apresentarem autoria conhecida e somente ínfima porcentagem culmina em final condenação do réu. Com isso, a desconfiança nas instituições caminha muitas vezes ao lado do desejo de vingança. Sabe-se também que há dificuldades de colheita de provas e oitiva de vítimas sem incorrer em vitimização secundária (especialmente no caso de abuso sexual infantil). O direito estatal não alcança todas situações, como se verifica em favelas ou outras comunidades marginalmente incluídas diante da questão do pluralismo jurídico.

\footnotetext{
${ }^{57}$ Topoi são lugares comuns retóricos mais abrangentes de uma dada cultura, funcionam como premissas de argumentação, visto que, por não se discutirem, em razão de sua evidência, possibilitam a produção e a troca de argumentos.

${ }_{58}$ De acordo com Boaventura de Sousa Santos, o conhecimento-emancipação transforma o estado de ignorância do colonialismo em um estado de saber da solidariedade; ao passo que o conhecimento-regulação conhece transformando o caos em ordem. Nesse sentido: A crítica da razão indolente: contra o desperdício da experiência, $4^{\mathrm{a}}$ ed., São Paulo, Cortez Editora, 2002, p. 78-81.
} 
A construção de um saber interdisciplinar ${ }^{59}$ entre técnicos de diversas áreas no atendimento a vítimas de violência exige dos profissionais uma abertura para o diálogo e troca com outras área. Talvez o encontro entre os operadores do direito e as vítimas, especialmente as de classes mais populares, implique num diálogo intercultural; na medida em que a cultura popular a respeito da Justiça formal, das leis e do direito formal seja bastante diversa da cultura jurídica formal. Nesse cenário, o direito como instrumento de direção e promoção social parece melhor se adequar à linguagem dos direitos humanos, embora o direito também se caracterize como técnica de controle e organização social ${ }^{60}$.

O direito como técnica implica um conhecimento jurídico meramente informativo e despolitizado partindo-se de um sistema legal tido como completo, lógico e formalmente coerente. Nesse sistema normativo, ao direito positivo importa apenas estabelecer sanções como conseqüência do descumprimento de prescrições normativas - tal descumprimento é visto apenas como conduta contrária àquela fixada pela norma, sem valorar como imoral ou eticamente condenável. Nessa ótica, o direito é tido como um sistema de normas para tratar de conflitos sociais de maneira exclusivamente formal, fragmentando-os, individualizando-os e trivializando-os para melhor equacioná-los funcionalmente por meio de decisões judiciais - o que não parece responder à realidade e todas implicações políticas, econômicas, sociais e culturais.

O direito como instrumento de direção e promoção social pressupõe um conhecimento jurídico multidisciplinar a partir de uma dúvida sobre a dimensão política, as implicações sócio-econômicas e a natureza ideológica da ordem legal. Tem por objetivo a consecução de um equilíbrio material entre os diferentes setores, grupos e classes sociais, o que implica em normas com propósitos compensatórios, redistributivos e protetores. Nesse sistema, as normas jurídicas são aplicadas de modo legítimo e eficaz se conectadas hermeneuticamente à realidade social e econômica, integrando-a como parte necessária do sistema legal. Um dos desafios dessa concepção de direito é o papel potencialmente “criador" e o grau de "discricionariedade" da argumentação e decisão jurídica, na medida

\footnotetext{
${ }^{59}$ Consideraremos multidisciplinar a situação em que várias áreas que estão presentes na equipe, mas não necessariamente com uma troca entre si para construir um saber novo, pois as áreas podem atuar cada uma na sua especificidade sem interagir com outras disciplinar. $O$ saber interdisciplinar pressupõe uma intersecção entre diferentes áreas do conhecimento, com discussão, troca e atuação conjunta, sem que cada área perca suas características. $\mathrm{Na}$ transdisciplinaridade esses diferentes saberes atuam de uma forma mais complexa e integrada, criando-se um novo saber comum a todas as áreas, e cada uma dessas áreas tem propriedade e conhecimento sobre as demais. Considera-se também que o saber transdisciplinar pode integrar áreas e atores de diferentes organizações. O tema será abordado na Parte II, sobre Atendimento às vítimas de violência.

${ }^{60}$ José Eduardo Faria, Introdução: o Judiciário e o desenvolvimento sócio-econômico, in: Direitos humanos, direitos sociais e justiça. São Paulo: Malheiros Editora, 1998, p. 11-29.
} 
em que "encara o ordenamento jurídico na perspectiva de um projeto político-normativo cujos dispositivos, para serem aplicados, exigem uma interpretação capaz de adequá-los ao contexto sócio-econômico"61 Assim, o ordenamento jurídico aparece, não como uma estrutura logicamente coerente e harmoniosa, mas como um construído histórico refletindo múltiplos valores e interesses de diferentes setores, grupos e classes sociais em confronto; portanto, com diversas "normas-origem" das quais derivam várias cadeias normativas que devem ser interpretadas à luz da realidade material.

Essa concepção do direito como instrumento de direção e promoção social exige a conciliação do saber jurídico especializado com um saber mais amplo e profundo sobre a produção, função e condições de aplicação do direito positivo - o que exige uma "reflexão multidisciplinar capaz de propiciar desvendamento das relações sociais subjacentes às normas e às relações jurídicas e de fornecer aos magistrados ${ }^{62}$ não apenas métodos mais originais de trabalho mas, igualmente, informações novas, de natureza econômica, política e sociológica."63

Nesse contexto, há que se promover o conhecimento-emancipação, em detrimento do conhecimento-regulação - de forma a promover um atendimento à vítima de violência que promova a cidadania e autonomia do sujeito. Para tanto, há que se praticar relações emancipatórias, baseadas na igualdade e diferença, estimulando-se o diálogo, o caráter coletivo e a criação conjunta.

A demanda jurídica parece ser mais facilmente explicitada pelas vítimas, talvez por ser uma demanda mais concreta e pontual e, por isso, mais fácil de lidar ou mais exigida socialmente. A demanda por Justiça é constante no discurso de vítimas de violência e a noção de "Justiça" pode ter diferentes acepções nem sempre correspondentes ao sistema de justiça representada pelo Poder Judiciário. O mais conhecido pelas vítimas é a figura do advogado e o ressarcimento do dano pela via judicial. A vítima em geral quer uma "justiça" que restaure a ordem, ocultando um sofrimento e desamparo com dano sofrido ou com a perda. Pouco se estuda e se discute sobre as possibilidades de um atendimento que lide com o dano ou lesão sofrida pela vítima integrando o aspecto jurídico, social e psicológico. Diante da violência e suas conseqüências, muitas questões jurídicas emergem

\footnotetext{
${ }^{61}$ José Eduardo Faria, ob. cit., p. 24.

${ }^{62}$ Ressalte-se que tudo isso se refere também aos operadores do direito em geral, sendo fundamental uma reflexão cuidadosa sobre o tipo de direito ensinado nas faculdades e uma discussão sobre função social dos operadores do direito, em contraposição à formação e cultura jurídica ainda individualista e formalista.

${ }^{63}$ José Eduardo Faria, ob. cit., p. 26.
} 
e a vítima pode não ter respaldo ou suporte adequado e muitas vezes não conhece seus direitos e os trâmites jurídicos para exerce-los.

A resposta formal de instâncias jurídicas e de segurança não são suficientes para o rompimento do ciclo de violência, mostrando-se necessária uma atuação interdisciplinar e integral de atenção à vítima. A chamada "lei do silêncio" em determinadas comunidades, as rígidas sanções frente ao descumprimento de regras dos grupos, o medo de testemunhar em juízo e ameaças são alguns exemplos na insuficiência do Direito estatal para a solução do problema da violência ${ }^{64}$.

Uma abordagem da violência e seus efeitos na perspectiva da vítima requer o respeito aos direitos de participação, proteção e reparação; assim como requer a assistência e tratamento da vítima e o acesso à justiça. Essa perspectiva exige uma percepção da complexidade da violência e da possibilidade de a vítima agir de forma violenta reproduzindo a agressão. As demandas da vítima podem ser de natureza jurídica, social, psicológica ou médica, dentre outras. Embora a assistência jurídica seja mais conhecida e demandada pela população em geral, não é a única forma de atendimento a vítimas de violência; outros atores, além dos operadores do direito, também têm responsabilidades no rompimento do ciclo de violência. Os operadores do direito são constantemente convidados a solucionar questões de diversas áreas, mas sem uma formação que privilegie o diálogo e a troca.

Num atendimento interdisciplinar e integral com perspectiva de direitos humanos, o olhar e interação com a vítima considera a história de vida e a possibilidade de mudanças e de transformação do/pelo sujeito; não se trata de um objeto de intervenção fragmentado. Daí a necessidade de diálogo e interação entre os diferentes profissionais e áreas de saber. Nesse contexto, a linguagem dos direitos humanos ocupa um lugar fundamental no atendimento a vítimas de violência. Os profissionais de atendimento direto às vítimas, se apropriados da linguagem dos direitos humanos, talvez possam multiplicar essa lógica nos atendimentos. Os diferentes olhares e diferentes intervenções podem compor um atendimento integral e interdisciplinar pautado na lógica dos direitos humanos.

\footnotetext{
${ }^{64}$ Vítimas e algozes freqüentam os mesmos bairros e os homicídios ocorrem nas proximidades das residências das vítimas em $48 \%$ dos casos analisados em pesquisa realizada com familiares de vítimas de homicídios praticados entre 1998 a 1999. De acordo com Vidas Nuas, mortes banais: os homicídios em São Paulo através da fala de suas vítimas indiretas. Caderno de Resultados de Pesquisa realizada em parceria da Pontifícia Universidade Católica, Centro de Referência e Apoio à Vítima e Secretaria da Justiça e Defesa da Cidadania do Estado de São Paulo, 2003.
} 
O psicólogo, nas intervenções, pode fortalecer o sujeito internamente e reforçar a noção de autonomia e alteridade, de respeito ao outro e tolerância - e dessa forma, abordar o respeito à dignidade humana (de todo ser humano, seja ele vítima ou agressor) e colaborar para o possível rompimento do ciclo de violência. Ao problematizar a dignidade do outro, seja agressor ou vítima, pode-se auxiliar na formação da identidade do sujeito (no momento vivida como vítima), para uma construção de cidadania e emancipação, com base no respeito aos direitos humanos.

$\mathrm{O}$ assistente social, da mesma forma, pode intervir com uma abordagem baseada nos direitos humanos ao trabalhar a inserção do sujeito no meio em que vive, assim como abordar noções de direito e respeito à dignidade humana. Ao encaminhar para uma entidade da rede de atendimento pode reforçar o direito (direito à saúde, direito à educação, direito ao lazer, direito à moradia digna, liberdade de reunião e associação, igualdade, dentre outros) e promover a autonomia. Se o encaminhamento for visto como um favor, a tendência é tutelar o sujeito. Ao passo que auxiliar na elaboração de estratégias para solução dos problemas, buscando apoio na rede social da vítima e mobilizando-a para sua utilização como cidadã, reforça-se uma noção de direito e de autonomia, em oposição ao favor ou benesse.

O advogado, por sua vez, em sua atuação na defesa do direito da vítima, pode agir de forma tuteladora ou promovendo sua autonomia, ainda que com uma mesma ação proposta judicialmente. A ação do operador do direito pode responder uma demanda imediata, sob o risco de (ou colaborar para) a vítima manter-se numa posição passiva e de receptora de favores, sem trabalhar questões mais complexas do sujeito, que podem e devem ser abordadas de forma interdisciplinar. A orientação e acompanhamento dos casos pelo advogado pode auxiliar na prevenção de vitimização secundária, na medida em que o profissional orienta e oferece um suporte à vítima. Estimulando a vítima a exercer seus direitos, pode-se favorecer a visibilidade de suas questões (dar voz às vítimas). Divulgando-se os direitos da vítima e os direitos do réu, pode-se sensibilizar para a universalidade do direito, que se aplica para todos.

Trata-se de diferentes formas de intervenção, que podem contribuir de alguma forma para a mudança da posição de vítima para a de cidadão. Numa lógica de direitos humanos, a atuação do advogado deverá contribuir para a realização dos direitos e autonomia do sujeito. A composição entre esses diferentes olhares e formas de intervenção possibilita uma apropriação do direito de forma mais efetiva pelo sujeito em atendimento, e 
com base nisso, será maior a tendência a romper o ciclo de violência e vitimização, com a possibilidade de diálogo e troca.

A linguagem dos direitos humanos pode favorecer a formação da identidade do sujeito baseada no respeito à dignidade do outro (subjetivamente, quem e como é visto/sentido o outro: como objeto ou sujeito, como igual, diferente ou desigual), tal identidade se inter-relaciona com o ambiente social inserido - a comunidade e as relações sociais podem influenciar a referência que tem o sujeito: as relações com outros sujeitos e o respeito à dignidade do outro (partindo-se da relação do sujeito com seu ambiente social, quem cabe nesse conceito de "outro"). Tudo isso numa interdependência com as normas, que dialogam com o sujeito na sua identidade e também com a sociedade e suas regras.

Uma cultura de direitos humanos pressupõe uma transformação da realidade através de um trabalho cotidiano e constante, levando-se em consideração toda a complexidade e ambivalência da modernidade. Diversos atores são mestres nos valores e princípios que deveriam guiar a conduta de respeito aos direitos humanos. "O aprendizado de valores éticos, princípios e condutas morais resulta não do contato com um especialista ou do ensino à parte e específico, mas da convivência difusa com todos os que nos cercam. (...) Nesse sentido, a educação ética não é tarefa de especialista, mas de toda a comunidade, não é fruto de um esforço isolado, mas de uma ação conjunta e contínua de todo o entorno social." ${ }^{\text {65 }}$. Assim, o êxito na tarefa depende de um esforço coletivo, e os operadores do Direito são apenas alguns dos atores responsáveis.

O Direito tem importante papel no atendimento a vítimas de violência, mas sozinho dificilmente soluciona a questão. Ter informações sobre o resultado de investigações e de processos é também um dado relevante para a elaboração do luto e para confiança nos mecanismos institucionais de solução de conflito. A integração e a interdisciplinariedade parecem responder melhor a essa proposta de rompimento do ciclo de violência e para efetivação dos direitos humanos. Diferentes formas de intervenção podem contribuir de maneira mais eficaz para a mudança do sujeito da posição de vítima para a de cidadão que exercita e reivindica seus direitos. A composição entre diferentes olhares e formas de atuação pode possibilitar uma apropriação dos direitos de forma mais efetiva pelo sujeito em atendimento e, com base nisso, maior tendência a romper o ciclo de violência e vitimização.

\footnotetext{
${ }^{65}$ José Sérgio Carvalho de Fonseca. “Podem a ética e a cidadania ser ensinadas?”, in: Jovens Lideranças Comunitárias e Direitos Humanos, São Paulo, Imprensa Oficial, 2004, p. 42.
} 
A teoria e a prática dos direitos humanos deve ser difundida e apropriada pela equipe de atendimento, a fim de que nas intervenções a noção de dignidade humana e direitos humanos possa ser trabalhada sob diferentes aspectos no decorrer do atendimento. Cada área contribui, ao seu modo, com seu olhar e intervenção, na realização desses direitos. Por outro lado, os mecanismos de proteção e defesa dos direitos humanos devem ser apropriados e utilizados pelos operadores do direito, difundindo-se uma cultura jurídica de promoção social e uma hermenêutica de valores. Assim, a abordagem dos direitos humanos no atendimento interdisciplinar às vítimas de violência pode ser um importante instrumento na efetivação dos direitos e emancipação do sujeito.

\subsection{A experiência do Tribunal Penal Internacional}

Nesse sentido, parece interessante verificarmos como os direitos da vítima tem sido tratado no âmbito internacional de proteção dos direitos humanos. Assim, a experiência do Tribunal Penal Internacional (TPI) e da Corte Interamericana de Direitos Humanos podem contribuir para o estudo do atendimento às vítimas, na medida em que consideram os direitos das vítimas em seus procedimentos e decisões. Não realizaremos um estudo aprofundado sobre essas experiências, apenas indicaremos algumas medidas que possam contribuir para a política nacional.

A experiência internacional pode auxiliar na discussão sobre a prática no Brasil quanto à legislação adotada (ou proposta), quanto aos serviços oferecidos e quanto à reparação adotada, assim como em relação às medidas a serem adotadas para o respeito, proteção e implementação dos direitos das vítimas. A definição de um perfil das vítimas de violência é uma tarefa bastante complexa ${ }^{66}$, que não será objeto do presente trabalho, que terá como foco de análise o atendimento realizado às vítimas de violência a partir do olhar dos técnicos envolvidos.

Tribunal Penal Internacional foi criado pelo Estatuto de Roma, de 1998, em vigor desde julho de 2002 . Até $1^{\circ}$ de junho de $2008^{67}, 106$ Estados haviam ratificado o Estatuto

\footnotetext{
${ }^{66}$ Verifica-se uma multiplicidade de interesses de vítimas de violência e demandas por justiça, o que torna complexa e difícil a definição de um interesse das vítimas, inseridas em culturas diversas atingidas pela violência - por exemplo, após o regime do apartheid na África do Sul, nas Comissões de Verdade e Reconciliação, o interesse maior da comunidade negra era a informação sobre os fatos ocorridos, pouco se discutindo sobre a punição dos autores ou reparação pelos danos. O que não se verifica em todas as situações de violência, em que, por exemplo, a vítima pode ter maior interesse na punição dos responsáveis ou reparação dos danos.

${ }_{67}$ De acordo com: http://www.icc-cpi.int/statesparties.html (acesso em 25/07/08). Do universo de 106 Estados-partes, 30 são do continente africano, 13 da Ásia, 16 do Leste Europeu, 22 da América Latina e Caribe, e 25 da Europa Ocidental e outros países.
} 
de Roma e, dessa forma, se submetido à jurisdição do Tribunal Penal Internacional. O Brasil ratificou o Estatuto de Roma em 25 de setembro de 2002. Até junho de 2008, havia 4 situações perante o Tribunal Penal Internacional: situação sobre a República Democrática do Congo (ICC-01/04); situação sobre Uganda (ICC-02/04); situação de Darfur no Sudão (ICC-02/05) e situação da República Centro Africana (ICC-01/05).

\section{a) A inovação do TPI em relação ao papel da vítima}

A inclusão dos direitos das vítimas no Tribunal Penal Internacional demonstra o caráter inovador e um desafio para a justiça penal internacional ${ }^{68}$. No TPI a vítima tem papel autônomo, embora limitado pelos direitos de defesa e garantias de julgamento justo e imparcial. Os direitos das vítimas encontram-se esparsos no Estatuto de Roma, nas Regras de Procedimento e Prova, no Regulamento do Tribunal e no Regulamento da Secretaria do TPI.

A definição de vítima do TPI é bastante ampla e pode abranger qualquer pessoa que tenha sofrido algum dano em conseqüência de crime de competência do tribunal, desde a vítima direta, até a pessoa indiretamente atingida; incluindo-se também as organizações ou instituições que tenham sofrido danos diretos a algum de seus bens que esteja dedicado à religião, à instrução, às artes, às ciências ou à benevolência, e a seus monumentos históricos, hospitais e outros lugares e objetos que tenham fins humanitários - de acordo com a regra $n^{\circ} .85$ das Regras de Procedimentos e Provas do Tribunal. Essa definição tem como antecedente a já mencionada Declaração de 1985; mas não é específica em relação a vitimização direta ou indireta.

O alcance dessa noção de vítima e a abrangência da noção de "dano", entretanto, deverão ser definidos a partir da interpretação do tribunal. Serão analisadas duas decisões do Tribunal a respeito da participação de vítimas nos procedimentos e a identificação e requisitos necessários para a caracterização de vítima perante o tribunal.

\section{b) Os direitos das vitimas perante o Tribunal Penal Internacional}

Os direitos das vítimas perante o TPI abrangem o direito à participação, o direito à proteção e o direito à reparação - tais direitos não são absolutos, pois há limites com o

\footnotetext{
${ }^{68}$ Os tribunais internacionais antecessores do Tribunal Penal Internacional - Tribunal de Nuremberg, Tribunal de Tóquio, Tribunal ad hoc para ex-Iugoslávia e Tribunal ad hoc para Ruanda - não previam em seus estatutos a participação das vítimas nos procedimentos, e praticamente não havia a menção à inclusão de seus direitos na jurisprudência desses tribunais. A vítima não tinha uma participação legítima nos julgamentos desses tribunais ad hoc e sua participação se resumia à condição de testemunha.
} 
respeito ao direito de defesa do acusado e julgamento justo e imparcial. O exercício dos direitos das vítimas encontra-se condicionado à decisão dos juízes do TPI, os quais julgarão em cada caso o exercício dos direitos da vítima para garantir o julgamento justo. A participação nos procedimentos do Tribunal é uma das principais inovações em relação ao tratamento dispensado às vítimas.

O direito à participação é o principal direito consagrado na estrutura do TPI e está previsto no artigo 68 (3) do Estatuto de Roma. A participação abrange o direito de as vítimas apresentarem e terem consideradas suas opiniões e observações quando seus interesses pessoais se virem afetados por determinada atuação do TPI; para isso devem apresentar solicitação por escrito ao Secretário do Tribunal - conforme regra 89 (1) das Regras de Procedimento e Prova. As solicitações serão analisadas pelo Tribunal, o qual decide sobre o status de vítima ${ }^{69}$. O tribunal já decidiu sobre o exercício do direito de participação e considerou que as vítimas podem exercer esse direito em qualquer etapa dos procedimentos, ou seja, tanto em fase de inquérito, quanto no processo, inclusive apelação, e na reparação ${ }^{70}$.

De acordo com Paulina Vega González ${ }^{71}$ existirão diferentes grupos de vítimas nas diferentes fases do processo perante o Tribunal e haverá a necessidade de distinguir vítima da situação, vítima do caso (fatos analisados) e vítima da pessoa do condenado. Isso em razão da possibilidade de exercício do direito à participação em quaisquer das etapas dos procedimentos diante do tribunal, que analisará cada solicitação de participação.

Em cada uma das fases, a participação da vítima terá uma abrangência específica: por exemplo, em fase de inquérito, as "vítimas da situação" poderão enviar informações ao Procurador para provocar o início de uma investigação, ou outros atos que contribuam para o esclarecimento da situação investigada. As "vítimas dos fatos" seriam aquelas envolvidas no processo já em curso diante do TPI, submetido a julgamento pelo Procurador em relação a determinados fatos imputados a um suposto responsável pelos crimes processados. Por fim, as "vítimas do condenado" seriam aquelas que demonstraram terem sofrido danos produzidos pelos fatos pelos quais o responsável foi condenado e, no processo, solicitam a reparação desses danos.

\footnotetext{
${ }^{69} \mathrm{Na}$ prática, em alguns casos tem sido designado um juiz singular na Câmara de Questões Preliminares para analisar tais solicitações, como na situação de Uganda.

${ }^{70}$ Vide decisão de 17 de janeiro de 2006, da Câmara de Questões Preliminares I do TPI, referente à situação da República Democrática do Congo (ICC-01/04-101-tEN.corr).

71 O papel das vitimas nos procedimentos perante o Tribunal Penal Internacional: seus direitos e as primeiras decisões do Tribunal, in: Sur - Revista Internacional de Direitos Humanos, São Paulo, ano 3, número 5, 2006.
} 
Por fim, a complexidade aumenta se levarmos em consideração também as vítimas que não participarem dos processos perante o TPI - seja por falta de comprovação da condição de vítima nos procedimentos, seja pela ausência de comprovação de danos relacionados aos fatos imputados, seja pelo desconhecimento dessa possibilidade, seja qual for o motivo. O cenário a ser enfrentado pelo TPI torna-se ainda mais desafiador diante da possibilidade de priorização de determinados fatos a serem investigados ou processados, por exemplo, em relação aos casos em que os responsáveis tenham maior grau de responsabilidade nos crimes, em detrimento aos casos em que os responsáveis tenham supostamente menor grau hierárquico.

O direito à participação abrange ainda o direito de eleger representação legal que fará assistência jurídica ${ }^{72}$; o direito à publicidade dos procedimentos; e o direito à notificação e informação dos avanços do procedimento, decisão da Câmara, data da audiência etc. O direito à proteção da vítima, previsto nos artigos 68 (1) e 43 (6) do Estatuto de Roma, inclui a garantia da segurança e bem-estar das vítimas e testemunhas. $\mathrm{O}$ Tribunal prevê ainda a adoção de medidas gerais de prevenção a todos os órgãos do TPI para reduzir riscos de vitimização secundária e prevê também medidas diretas ou concretas para aplicação no caso concreto. Para fins de proteção das vítimas, algumas medidas podem ser adotadas, como a confidencialidade.

O direito à reparação é previsto no artigo 75 do Estatuto de Roma e se refere ao direito da vítima reclamar reparação pelos danos sofridos, independentemente de ter exercido ou não o direito de participação.

c) A organização do TPI para cumprir sua incumbência em relação aos direitos das vítimas

$\mathrm{Na}$ estrutura do TPI há alguns órgãos de atenção às vítimas das mais graves violações de direitos humanos definidas como crimes internacionais. Para viabilizar o exercício dos direitos das vítimas, o TPI conta com uma Unidade de Apoio a Vítimas e Testemunhas, uma Seção para Participação das Vítimas, um Fundo Fiduciário em beneficio das vítimas e testemunhas e um Escritório Público de Defesa das Vítimas.

A Unidade de Apoio a Vítimas e Testemunhas - prevista no Estatuto de Roma, artigo 43 (6) - tem função de: velar pela segurança das vítimas e testemunhas e todas pessoas que possam sofrer riscos em conseqüência de seu contato com o tribunal

\footnotetext{
${ }^{72} \mathrm{O}$ tribunal tem adotado a figura de representação comum às vítimas.
} 
(promoção e adoção de políticas institucionais do TPI para garantir integridade física e psíquica das vítimas); providenciar que todos os órgãos do TPI que tenham contato com vítimas adotem medidas necessárias para garantir seu direito à proteção e medidas tendentes a evitar que o contato das vítimas ou testemunhas com o Tribunal seja uma experiência em si traumática ${ }^{73}$; implementar medidas e programas de proteção.

A Seção para a Participação e a Reparação das Vítimas - previsto no artigo 86 (9) do Regulamento do Tribunal - tem como atribuições: viabilizar o exercício dos direitos à participação e à solicitação de reparação; prestar devida assistência às vítimas e testemunhas em todas etapas do procedimento perante o tribunal; organizar seminários, sensibilização às vítimas para que exercitem seus direitos; ajudar vítimas para que exercitem seus direitos e conheçam seu alcance e a incumbência do tribunal; processar solicitações recebidas e divulgar informação sobre tais pedidos; assistência às vítimas na eleição de representante comum; dentre outras.

O Fundo Fiduciário em benefício das vítimas e suas famílias está previsto no artigo 79 do Estatuto de Roma, para contribuir no cumprimento da função de reparação do Tribunal. Os recursos podem ser provenientes de bens apreendidos do acusado ou do condenado; de ordens de reparação e de contribuições voluntárias dos Estados, instituições, organizações ou indivíduos.

O Escritório Público de Defesa das Vítimas - previsto no Regulamento do Tribunal, norma 81 - é independente da Secretaria do Tribunal e presta apoio e assistência às vítimas e seus representantes legais perante o tribunal. O Escritório Público de Defesa das Vítimas tem como atividades: o assessoramento especializado e a investigação e comparecimento perante a Câmara para viabilizar o exercício do direito das vítimas. Outra importante função desse escritório é aproximar vítimas e o TPI, em razão da distância do tribunal em Haia e a localização das vítimas nos Estados-partes.

\section{d) As primeiras interpretações do TPI sobre o direito das vítimas}

No âmbito das Câmaras de Questões Preliminares, destacam-se duas decisões recentes referentes aos direitos das vítimas, seu alcance e exercício nos procedimentos perante o TPI: uma decisão de 17 de janeiro de 2006, referente à situação da República Democrática do Congo (decisão da Câmara de Questões Preliminares I, registrada como

\footnotetext{
${ }^{73} \mathrm{O}$ Tribunal prevê que a Unidade preste atenção particular às vítimas de crimes de violência sexual e aos menores de idade que tenham contato com o tribunal, a fim de evitar a vitimização secundária.
} 
ICC-01/04-101-tEN.corr ${ }^{74}$ ); e outra decisão de 10 de agosto de 2007 referente à situação de Uganda (decisão do juiz singular Mauro Politi, designado pela Câmara de Questões Preliminares II para as questões relativas às vítimas, registrada como ICC-02/04-101) ${ }^{75}$.

A decisão de 17 de janeiro de 2006, sobre a situação da República Democrática do $\mathrm{Congo}^{76}$, foi a primeira decisão em que o TPI apresentou uma interpretação sobre o conteúdo dos direitos das vítimas, particularmente em relação à participação ${ }^{77}$.

A Câmara de Questões Preliminares I (CQP I) concluiu nessa decisão que o termo "procedimentos" não exclui a etapa de inquérito e, portanto, o artigo 68(3) do Estatuto de Roma outorga um direito geral de acesso ao TPI nessa etapa de inquérito. A CQP I reconheceu o papel independente que foi outorgado à vítima para expressar suas opiniões e resgatou de decisões de cortes regionais de direitos humanos a importância do papel das vítimas nos procedimentos penais para realização de seus direitos. Nesse contexto, a Câmara ressaltou a aplicabilidade do direito de participação em fase de inquérito e que a participação per se não põe em risco a integridade e objetividade do inquérito.

A Câmara de Questões Preliminares I concluiu ${ }^{78}$ que os interesses das vítimas se vêem necessariamente afetados de maneira geral durante a fase de inquérito, porque é nessa fase que se esclarecem os fatos constitutivos de crimes de competência do TPI e se identificam supostos responsáveis. Por isso, os interesses dos solicitantes são afetados na etapa de investigação da situação e a participação dos solicitantes pode servir tanto para esclarecer fatos constitutivos do crime, quanto para identificação de supostos responsáveis; assim como para posterior solicitação de reparação. Quanto ao reconhecimento da qualidade de vítima para o tribunal, foi concluído que basta provar que a pessoa sofreu

74 A decisão ICC-01/04-101-tEN.corr, de 17 de janeiro de 2006 referente à situação da República Democrática do Congo está disponível em: http://www.icc-cpi.int/library/cases/ICC-01-04-101_tEnglishCorr.pdf (acesso em 10/08/07).

${ }^{75}$ A decisão de 10 de agosto de 2007, referente à situação de Uganda (ICC-02/04-101) está disponível em http://www.icc-cpi.int/library/cases/ICC-02-04-101_English.pdf (acesso em 25/08/07)

${ }^{76}$ A investigação pela Procuradoria do TPI foi iniciada em junho de 2004. Em 23 de maio de 2005, a Promotoria ofereceu registro da situação da República Democrática do Congo perante a Câmara de Questões Preliminares I; e em 14 de junho de 2005 seis vítimas apresentaram individualmente solicitações de participação nos procedimentos. Após a apresentação de documentos e provas, em 17 de janeiro de 2006, a Câmara de Questões Preliminares I decidiu sobre tais solicitações (ICC-01/04-101-tEN.corr).

77 A Câmara já havia decidido sobre outras questões relativas a solicitação de medidas de proteção, informação adicional às vítimas, dentre outras; mas não em relação à participação nos procedimentos do tribunal.

${ }^{78}$ Nessa decisão foi nomeado um representante ad hoc da defesa para a situação da República Democrática do Congo, que representará os interesses de supostos acusados e foi decidido restringir o acesso a documentos classificados como não públicos. Foi ainda determinado que o Centro de Apoio à Vitima teria atribuição para prestar apoio e assistência necessária às vitimas; que Centro de Defesa deveria representar interesses e direitos da defesa dos acusados e que a Secretaria deveria redigir documentos e preservar caráter de confidencialidade. 
algum dano e que há "bases para acreditar" que o dano alegado foi produto de um crime sob jurisdição do tribunal.

Em relação à decisão de 10 de agosto de $2007^{79}$, sobre a situação de Uganda (ICC02/04-101), o juiz singular da Câmara de Questões Preliminares II designado para julgar todas as questões referentes às vitimas, ressaltou que vítima é toda pessoa natural que tenha sofrido dano, de acordo com o Estatuto de Roma. Foi destacado que a solicitação de participação da vítima deve conter necessariamente a comprovação de que o documento apresentado foi expedido por autoridade pública, com nome e data de nascimento, e documento com foto.

O juiz determinou que a Seção de Participação e Reparação das Vítimas elaborasse um relatório com informações sobre qual a idade legal em Uganda e informações sobre o sistema administrativo que permita a verificação dos documentos de crianças em relação ao preenchimento das três condições que devem ser comprovadas para o reconhecimento do status de vítima (documento oficial, nome e data de nascimento e foto). O juiz ressaltou que a vítima tem legítimo interesse no esclarecimento dos fatos em todas as fases do processo.

\subsection{A Experiência da Corte Interamericana de Direitos Humanos}

Analisaremos brevemente alguns aspectos da experiência da Corte Interamericana de Direitos, a qual reconhece a condição de vítima a toda pessoa cujos direitos foram violados nos termos da sentença proferida pela Corte ${ }^{80}$. Vale ressaltar que a Corte não constitui ninguém na condição de vítima; apenas reconhece essa condição em sua sentença. A pessoa cujos direitos protegidos na Convenção Americana de Direitos Humanos se alegam terem sido violados é denominada "suposta vítima", nos termos do Regulamento da Corte. Embora esses termos não façam distinção sobre vítima direta ou indiretamente atingida pela violação, a Corte não costumava considerar os familiares da vítima direta na condição de vítima em suas sentenças iniciais das décadas de 80 e início dos anos 90 .

\footnotetext{
${ }^{79}$ A decisão versou sobre o pedido de participação de 49 vítimas no processo sobre a situação de Uganda (ICC-02/04) e solicitação de 49 vítimas no processo sobre o caso Promotoria v. Joseph Kony, Vincent Otti, Okot Odhiambo e Dominic Ongwen (ICC 02/04-01/05).

${ }^{80}$ Conforme o artigo 2, item 31, do Regulamento da Corte Interamericana de Direitos Humanos, aprovada pela Corte no seu LXI período ordinário de sessões, realizado de 20 de novembro a 4 de dezembro de 2003; em vigor a partir de 10 de janeiro de 2004.
} 
Atualmente a Corte tem ampliado a noção de vítima além da pessoa que sofreu a violação de direito, considerando também os familiares das vítimas diretas ${ }^{81}$.

A participação das supostas vítimas nos procedimentos da Corte Interamericana encontra-se prevista no Regulamento da Corte, no artigo $23^{82}$. Essa redação foi adotada a partir do novo Regulamento da Corte em vigor desde $2001^{83}$ e provocou mudanças na forma de atuação da Comissão Interamericana de Direitos Humanos, assim como uma discussão sobre suas atribuições - especialmente nos casos em que houve divergências entre a posição da Comissão e do representante das vítimas. Nesse aspecto, a Corte afirmou que a representação das vítimas pode apresentar um entendimento jurídico distinto ao proposto pela Comissão Interamericana em relação a determinado direito, pode ainda alegar uma violação de direito não invocado pela Comissão, assim como pode fazer sua própria apreciação dos fatos ${ }^{84}$.

A participação da vítima de forma autônoma no procedimento perante a Corte Interamericana se encontra garantida também em relação à solicitação de medidas provisórias em casos contenciosos já em andamento perante esse tribunal, nos termos do artigo 25 do Regulamento da Corte. Entretanto a participação autônoma e efetiva das vítimas apresenta ainda alguns desafios, por exemplo nos casos em que há uma multiplicidade de vítimas e nem todas têm interesse em eleger um representante.

Ressalta-se o risco de vitimização secundária durante o procedimento na Corte e que no sistema interamericano não há uma Unidade de Apoio à Vítima, como previsto no TPI. Outros desafios se verificam em relação à participação da vítima no procedimento perante a Corte Interamericana quanto à paridade de armas entre as partes, a fim de se garantir efetivo contraditório. A vítima ainda não tem acesso direto à Corte Interamericana, dependendo da submissão do caso pela Comissão Interamericana; os gastos com o litígio internacional correm por conta das vítimas, que em alguns casos conseguem auxílio de organizações não governamentais para comparecer em audiências, por exemplo; os custos

\footnotetext{
${ }^{81}$ Nesse sentido, ver Caso Villagrán Morales y Otros (Niños de la calle), sentença de 19 de novembro de 1999; Caso Bámaca Velásquez, sentença de 20 de novembro de 2000; dentre outros.

${ }^{82}$ Dispõe o artigo 23 do Regulamento da Corte IDH: “1. Depois de admitida a demanda, as supostas vítimas, seus familiares ou seus representantes devidamente acreditados poderão apresentar suas petições, argumentos e provas de forma autônoma durante todo o processo. 2. Se existir pluralidade de supostas vítimas, familiares ou representantes devidamente autorizados, deverá ser designado um interveniente comum, que será o único autorizado para a apresentação de petições, argumentos e provas no curso do processo, incluídas as audiências públicas. 3. No caso de eventual discordância, a Corte decidirá sobre o pertinente."

${ }^{83}$ O Regulamento da Corte Interamericana de Direitos Humanos foi novamente alterado em 2006.

${ }^{84}$ Nesse sentido, ver Mónica Feria Tinta, La víctima ante la Corte Interamericana de Derechos Humanos a 25 años de su funcionamiento. In: Revista IIDH, vol. 43, 2006, p.159-203.
} 
processuais e horários são igualmente arcados pelas vítimas e somente em alguns casos com auxílio de organizações. Não obstante tais desafios e a fragilidade do suporte à vítima na estrutura do sistema interamericano, a participação das vítimas nos procedimentos perante a Corte Interamericana representa um avanço e uma consolidação do indivíduo como sujeito de direito internacional.

As experiências do TPI e da Corte Interamericana de Direitos Humanos podem contribuir para o respeito e a promoção dos direitos das vítimas em âmbito interno. Ao prever os direitos das vítimas e possibilitar sua participação nos procedimentos perante o tribunal, o TPI mostra-se bastante inovador e ao mesmo tempo com o desafio de conciliar a participação das vítimas e a justiça internacional.

O Tribunal Penal Internacional traz uma importante contribuição para difundir a importância do papel da vítima na obtenção de justiça e os direitos de participação, proteção e reparação da vítima não apenas no âmbito internacional, mas também no plano interno dos Estados-partes do Estatuto de Roma. A Corte Interamericana tem enfrentado questões referentes aos direitos das vítimas e se destacado na previsão de formas de reparação e na participação das vítimas nos procedimentos. Há de se ressaltar a necessidade de ampliação da participação da vítima nos procedimentos da Corte, inclusive com a possibilidade de peticionar diretamente e maior protagonismo e autonomia da vítima no exercício de seus direitos de participação nos tribunais internacionais e nacionais.

Nesse sentido, a compreensão das necessidades das vítimas mostra-se fundamental para sua defesa e para a resposta do sistema de segurança e justiça, assim como para a promoção de justiça. As experiências analisadas sugerem a premência de medidas internas no âmbito nacional - como uma legislação que considere a inclusão do direito das vítimas nos procedimentos penais e adoção de medidas administrativas, judiciais e legislativas para garantir o exercício desses direitos em âmbito interno, assim como a previsão de políticas públicas de atendimento a vitimas de violência, preferencialmente de forma interdisciplinar e integrada, garantindo-se a plena efetivação dos direitos das vítimas de violência. 


\section{Parte II}

\section{ATENDIMENTO ÀS VÍTIMAS DE VIOLÊNCIA NO BRASIL}

Nos capítulos seguintes serão estudadas algumas experiências de atendimento às vítimas de violência. Quando analisamos as práticas derivadas desses programas cabe perguntar: há uma efetiva integração nesse atendimento? A interdisciplinaridade é presente nos programas de atenção às vítimas? Como se dá, de fato, a reparação no Brasil? Quais os resultados apresentados?

$\mathrm{Na}$ tentativa de discutir essas questões, serão estudadas as experiências de dois ${ }^{85}$ centros de atendimento a vítimas de violência, em relação ao serviço prestado às vítimas, à interdisciplinaridade e à contribuição do direito nesse serviço - o Centro de Referencia e Apoio à Vítima (CRAVI), programa da Secretaria da Justiça e Defesa da Cidadania do Estado de São Paulo, que atende primordialmente familiares de vítimas de homicídio; e o Centro de Referência de Vítimas de Violência (CNRVV), do Instituto Sedes Sapientiae, que atende vítimas de violência doméstica e sexual.

Essas instituições trabalham com equipe multidisciplinar, o que possibilitará um levantamento de desafios de uma abordagem interdisciplinar no atendimento a vítimas de violência e efetivação dos direitos humanos. A violência objeto de cada instituição apontada é diversa, assim como o público atendido, o que possibilitará uma análise sobre diferentes políticas de atendimento a vítimas de violência - a partir de suas especificidades, composição da equipe, atividades desenvolvidas e desafios.

Inicialmente, vale destacar que não se trata, em absoluto, de uma avaliação do trabalho desenvolvido nesses centros, precursores e respeitados por sua atuação com vítimas de violência; mas sim de uma pesquisa que tem por objetivo discutir como emergem, nessas instituições, determinados temas como: a relação do trabalho de atendimento às vítimas de violência com os direitos humanos e ao papel do direito nesse atendimento.

Ambos os centros desenvolvem importante trabalho de atendimento às vítimas de violência, e representam uma referência na temática de trabalho - seja em relação à violência doméstica e sexual, no caso do CNRVV, seja em relação à violência fatal, no

\footnotetext{
${ }^{85}$ Em projeto de pesquisa e exame de qualificação, havia a proposta de trabalhar também com o Centro de Defesa dos Direitos da Criança e do Adolescente da Região Sé (CEDECA-Sé), que atende crianças e adolescentes em situação de rua e/ou de risco social na região central da Cidade de São Paulo. Entretanto, em razão de posicionamento e decisão interna da instituição, a pesquisa não pôde ser realizada nesse centro.
} 
caso do CRAVI. A escolha desses centros se justifica também pelo caráter pioneiro dessas instituições nas áreas de trabalho.

Assim, a partir da análise da prática dos serviços prestados por esses centros, pretende-se aprofundar a discussão e reflexão sobre a contribuição de diferentes formas de intervenção no atendimento às vítimas, e sobre a composição entre diferentes olhares e formas de intervenção como uma possibilidade de defesa e promoção dos direitos humanos de forma mais efetiva e, com base nisso, maior tendência a romper o ciclo de violência e vitimização. Ademais, esse trabalho pode ajudar a orientar a formulação de políticas públicas mais integradas de atenção às vítimas de violência. 


\section{Capítulo 3: O CENTRO DE REFERÊNCIA ÀS VÍTIMAS DE VIOLÊNCIA (CNRVV)}

Após alguns contatos telefônicos, foi agendada uma reunião em que a proposta de pesquisa da dissertação foi apresentada à coordenação de pesquisa do centro. Nessa ocasião, foi solicitada a realização de entrevistas com técnicos de diferentes formações e áreas de atuação no CNRVV e a coordenadora da área apresentou as principais atividades do centro. As entrevistas tiveram início na semana seguinte.

Foram realizadas oito entrevistas com técnicas e coordenadoras do Centro de Referência às Vítimas de Violência, no período de 14 de abril a 08 de maio de 2008 . As entrevistas foram previamente agendadas pela secretaria da instituição e realizadas em sala de atendimento ou na sala de reunião da equipe. Cada entrevistada preencheu um termo de consentimento e um breve questionário (anexo), antes de responder às perguntas de acordo com o roteiro de entrevista (anexo). As entrevistas tiveram duração de aproximadamente uma hora, sendo gravadas e posteriormente transcritas. Em razão de maior duração de algumas entrevistas ${ }^{86}$ outras tiveram que ser adiadas e remarcadas.

A partir do discurso das profissionais entrevistadas, por meio das tendências gerais, falas repetitivas e diferenças marcantes que emergiram nessas conversas, serão discutidos alguns pontos em relação ao trabalho interdisciplinar desenvolvido, dificuldades do atendimento às vítimas de violência, direitos humanos, vítimas e ao papel do direito nesse cenário.

\section{1. breve apresentação da instituição: histórico e missão}

$\mathrm{O}$ Centro de Referência às Vítimas da Violência (CNRVV) tem por objetivo "realizar trabalho de combate à violência doméstica, através de programas e políticas de intervenção" ${ }^{\text {87. }}$ O CNRVV tem atuação nas áreas de tratamento, prevenção, parcerias, pesquisa e formação, por meio das quais procura "intervir tanto no social quanto na saúde mental, buscando alternativas para que as vítimas, tanto a criança quanto o adolescente ou

\footnotetext{
${ }^{86}$ A previsão era de duração de 40 minutos, aproximadamente, para todo o procedimento da entrevista. Entretanto, ao realizar as entrevistas, foi verificado que a apresentação da pesquisa e preenchimento de termo e questionário exigiram mais tempo do que o previsto; além disso, algumas entrevistas demandaram maiores questionamentos não incluídos no roteiro.

${ }^{87}$ De acordo com o site institucional, disponível em: http://www.sedes.org.br/Centros/cnrvv.htm (acesso em 10/01/08)
} 
o adulto, tenham novas opções de vida, novas realizações enquanto sujeitos e possam interromper o caminho que leva quase sempre a vítima ao papel do agressor" ${ }^{\text {" }}$.

O Centro localiza-se no bairro de Perdizes, zona oeste de São Paulo. Originou-se em 1994 como um setor de Clínica Psicológica do Instituto Sedes Sapientiae ${ }^{89}$ - o Núcleo de Referência às Vítimas da Violência - com o compromisso da defesa dos direitos humanos, do Estatuto da Criança e do Adolescente e da cidadania. Nessa época, suas atividades se concentravam no atendimento psicossocial de pessoas em situação de violência doméstica, seja criança, adolescente ou seus familiares.

Em 1995, foi firmado convênio com Secretaria da Criança, Família e Bem-Estar Social do Estado de São Paulo para a realização de atendimento e prevenção às situações de violência doméstica. No ano seguinte, foi implantado um pólo piloto de prevenção no bairro do Jaguaré em São Paulo.

Em 2000, o Núcleo foi inserido pela Diretoria e pelo Conselho do Instituto Sedes Sapientiae na estrutura da instituição, em reconhecimento ao trabalho desenvolvido, como Centro de Referência às Vítimas da Violência (CNRVV) - com o objetivo de contribuir para o desenvolvimento integral de crianças e adolescentes, reduzindo situações de violência doméstica. Como Centro, foram ampliadas as atividades de prevenção dirigidas às comunidades, com intuito de favorecer visão crítica sobre o tema da violência doméstica, conscientização sobre direitos e deveres, trabalho em rede e formação de parcerias para atenção à infância e juventude.

O CNRVV foi vencedor do Prêmio Criança 2002, da Fundação Abrinq, na categoria "violência doméstica". No período de 2005 a 2007, o Centro contou com a parceria do Instituto WCF Brasil (World Childhood Foundation) e da Fundação Abrinq para a implantação de pólos de prevenção da violência doméstica.

As experiências do Centro foram sistematizadas e divulgadas em três principais publicações: O Fim do Silêncio na Violência Familiar: Teoria e Prática, em 2002, pela Summus Editorial; O Fim da Omissão: a implantação de pólos de prevenção à violência

\footnotetext{
${ }^{88}$ Conforme Ana Cristina Marcondes Moura [et al.]. Reconstrução de vidas: como prevenir e enfrentar a violência doméstica, o abuso e a exploração sexual de crianças e adolescentes. São Paulo, SMADS, Sedes Sapientae, 2008, p. 64.

89 O Instituto Sedes Sapientiae é uma instituição criada em 1975, em São Paulo, com trabalho sólido nas áreas da saúde mental, educação e filosofia. Conta com departamentos de formação em arte terapia, formação em psicanálise, formação em psicopedagogia, gestalt terapia, psicanálise, psicanálise da criança, psicodinâmica, psicodrama, reichiano; e, também, centros de filosofia, de educação popular, de educação de adultos e centro de referência às vítimas de violência; clínica, centro de referência em psicose, e vários cursos de especialização, aperfeiçoamento e de expansão. De acordo com site institucional: http://www.sedes.org.br (acesso em 04/12/08).
} 
doméstica, pela Fundação Abrinq, em 2004; e Reconstrução de vidas: como prevenir e enfrentar a violência doméstica, o abuso e a exploração sexual de crianças e adolescentes, pela SMADS e Sedes Sapientiae, em 2008.

Conforme o site oficial, o CNRVV busca "alternativas para que a criança e o adolescente possam romper com o pacto do silêncio, com a lógica da crueldade e interromper o caminho que leva, quase sempre, do lugar da vítima ao do agressor". Desenvolve programas de intervenção no social e na saúde mental no tratamento, prevenção, formação de profissionais, pesquisa, desenvolvimento de parcerias e divulgação do Centro, além das atividades administrativas. Esses programas são realizados “observando sempre um cuidado com a própria equipe de trabalho, fortalecendo os mecanismos internos de coesão e solidariedade", a fim de que os "aspectos destrutivos intrínsecos ao fenômeno" com o qual se lida, não retire a "vitalidade necessária a este trabalho".

O tratamento é desenvolvido numa perspectiva "transdisciplinar e interinstitucional”, com intervenções concretas e integradas junto a instâncias jurídicas, sociais, educacionais e de saúde. Cada caso segue um percurso a partir de um plantão social telefônico, para em seguida passar por uma triagem e encaminhamento psicossocial no CNRVV ou externo. O tratamento prioriza o grupo familiar e, quando isso não for possível, encaminha-se para grupos de crianças, de adolescentes, de pais/responsáveis, de casais e/ou de agressores. Esse serviço utiliza técnicas psicodramáticas, psicanalíticas e /ou sistêmicas.

O CNRVV, por meio de convênio com a Secretaria Municipal de Assistência e Desenvolvimento Social, da Prefeitura da Cidade de São Paulo, executa o Serviço de Proteção Social às Crianças e aos Adolescentes Vítimas de Violência, Abuso e Exploração e a suas Famílias - Programa Sentinela/Cuidar, nas regiões norte e oeste da cidade de São Paulo. Tal programa tem por objetivo “atender, através de um conjunto articulado de ações, crianças e adolescentes abusados ou explorados sexualmente; criar condições que possibilitem às crianças e adolescentes vitimados sexualmente e às suas famílias o resgate dos seus direitos, bem como o acesso aos serviços de assistência social, saúde, educação, justiça e segurança, esporte, lazer e cultura".

A partir da experiência do centro, verificou-se que programas preventivos colaboram na diminuição do uso da violência, seja física ou psicológica, nos processos educativos, na melhoria das competências familiares e difusão do conhecimento sobre 
desenvolvimento infanto-juvenil, possibilitando a identificação de procedimentos abusivos e vitimizadores. Nesse contexto, o CNRVV implanta e coordena "Pólos de Prevenção contra a violência doméstica" - estratégia utilizada no rompimento do ciclo de violência. Por meio de equipamentos socioeducacionais, como creches e núcleos socioeducativos na cidade de São Paulo, são desenvolvidos programas com crianças, adolescentes, pais e/ou responsáveis e profissionais da área da infância e juventude (da área da educação, esporte, lazer, cultura, saúde, social e justiça), com a finalidade de sensibilizar e mobilizar para o tema da violência doméstica, formar multiplicadores e subsidiar implantação de políticas públicas. Os pólos de prevenção buscam abrangência e repercussão social nas instituições e populações locais, o que evita a emergência de situações de risco e promove melhor proteção às crianças e aos adolescentes.

Cada nível de prevenção ${ }^{90}$ exige diferentes abordagens: a prevenção primária, com ações dirigidas ao conjunto da população, é trabalhada pelo CNRVV por meio de programas informativos para pais ou responsáveis pelo processo de desenvolvimento da criança e do adolescente e pela sensibilização da população sobre o tema da violência doméstica contra criança e adolescente, assim como por meio de fóruns de debates, palestras e seminários, visando a formação de uma rede transdisciplinar e interinstitucional de parceiros. A prevenção secundaria, que envolve a identificação precoce de populações em risco, é desenvolvida por ações como capacitação de profissionais que lidam diretamente com essa população e orientação e encaminhamento a serviços especializados, quando se mostrar necessário. Por fim, a prevenção terciária (se a violência não pôde ser evitada, as conseqüências devem ser reduzidas, prevenindo-se que a violência revitimize a vítima ou seja disseminada) é abordada pela equipe do CNRVV por meio de programas de acompanhamento psicológico para crianças e adolescentes vitimizados e seus familiares, e também para o agressor.

A implantação de pólos de prevenção iniciou-se em 1996 com um projeto piloto na favela do Jaguaré com atividades de sensibilização sobre o tema da violência doméstica contra crianças e adolescentes, por meio de oficinas realizadas pelos técnicos da instituição. No primeiro ano eram realizadas intervenções e oficinas com crianças, adolescentes, pais e profissionais da rede; no ano seguinte a equipe do então Núcleo de

\footnotetext{
${ }^{90}$ A Organização Mundial de Saúde (OMS) reconhece três níveis de prevenção: primário, que consiste em estratégias direcionadas ao conjunto da população como um todo, a fim de reduzir a incidência da violência ou o índice de ocorrência de novos casos; secundário, em que há uma identificação anterior da população de risco, o que permite a adoção de medidas específicas para essa população; nível terciário, em que as ações de prevenção são voltadas para reduzir as conseqüências relacionadas ao fenômeno, depois de sua ocorrência.
} 
Referência às Vítimas de Violência acompanhava e assessorava os profissionais da rede local, os quais continuavam a sensibilização da comunidade por meio das oficinas e fomentavam a articulação da rede local. A partir dessa experiência, foram implementados outros pólos na favela de Paraisópolis, no Dom Orione na região do Bixiga (com a população moradora dos cortiços) e no Rio Pequeno.

Desde então foram realizadas outras atividades de capacitação e sensibilização sobre o tema da violência doméstica contra crianças e adolescentes em postos de bombeiros na cidade de São Paulo (2001), para profissionais de saúde (em 2002) e, com a sistematização da experiência e metodologia de implantação de pólos de prevenção, foram implantados simultaneamente vinte pólos em 2004. A partir de então a equipe do CNRVV não coordena diretamente cada uma das oficinas com a comunidade, mas capacita os profissionais desses pólos, assessora e supervisiona as atividades de cada pólo implantado.

Atualmente há cerca de 48 pólos já implantados na cidade de São Paulo: 2 na região noroeste; 6 na região norte; 1 no centro; 10 na região oeste da cidade; 7 no sudeste; 5 na região leste $1 ; 5$ na região leste $2 ; 3$ pólos no centre-sul e 9 na região sul da cidade ${ }^{91}$.

Está em andamento um projeto, em parceria com a Secretaria Municipal de Assistência e Desenvolvimento Social, da Prefeitura da Cidade de São Paulo, para capacitação e implantação de novos pólos de prevenção em Núcleos Socioeducativos em diversas regiões da cidade de São Paulo. O Centro tem expectativa de ampliação desses pólos de prevenção para escolas da rede pública e/ou partículas, e outros equipamentos sociais; mas depende de financiamento estatal ou privado para esse fim.

O histórico do trabalho de prevenção do CNRVV ${ }^{92}$

1988 Início do atendimento psicológico de crianças, adolescentes e familiares vítimas de violência doméstica, pelo Instituto Sedes Sapientiae.

1994 Início, na Clínica de Psicologia do Instituto Sedes Sapientiae, das atividades do Núcleo de Referência às Vítimas de Violência (NRVV), cujo principal objetivo é a luta contra a violência doméstica a que são submetidos crianças, adolescentes e familiares, incluindo o agressor (aquele que comete o ato violento).

1995 O NRVV estabelece convênio com a Secretaria da Criança, Família e Bem-Estar Social do Estado de São Paulo (SCFBES) para realizar atendimento e prevenção às situações de violência doméstica.

1996 Início do curso de aperfeiçoamento em psicoterapia e prevenção da violência doméstica voltado para profissionais de várias áreas e realização do primeiro Fórum de Debates do NRVV em parceria com instituições de Justiça, saúde, educação e assistência social. Nesse mesmo ano, é implantado um pólo piloto de prevenção no bairro do

\footnotetext{
${ }^{91}$ De acordo com Reconstrução de vidas, p. 73.

92 De acordo com RE Construção de Vidas: como prevenir e enfrentar a violência doméstica, o abuso e a exploração sexual de crianças e adolescentes, p. 84.
} 
Jaguaré, em São Paulo. A partir dele, vários outros pólos foram sendo implantados em diferentes bairros da periferia de São Paulo.

2000 O NRVV é convidado pela diretoria do Instituto Sedes Sapientiae a integrar a instância de centros, passando a se chamar Centro de Referência às Vítimas de Violência do Instituto Sedes Sapientiae, e é convidado pelo Ministério da Justiça, como organização da sociedade civil, a participar da elaboração do Plano Nacional de Enfrentamento ao Abuso e Exploração Sexual contra Crianças e Adolescentes, em Natal, no Rio Grande do Norte.

2001 Estabelecimento de convênio com a Secretaria Estadual de Assistência e Desenvolvimento Social (SEADS) para a implantação do Programa Unificado Bem Me Quer, que tem como objetivo acolher e tratar as vítimas de abuso sexual e prevenir a violência doméstica contra crianças e adolescentes. Início da realização de ofícinas para pais, educadores e crianças em seis Postos de Bombeiros da cidade de São Paulo.

2002 Início de oficinas de capacitação e sensibilização sobre violência doméstica com profissionais da área de saúde do município de São Paulo. É publicado o livro O Fim do Silêncio na Violência Familiar: Teoria e Prática, pela Summus Editorial, e o Centro é vencedor do Prêmio Criança 2002, da Fundação Abrinq, na categoria violência doméstica.

2003 O CNRVV sistematiza seu Projeto de Implantação de Pólos de Prevenção.

2004 Lançamento da publicação O Fim da Omissão: a Implantação de Pólos de Prevenção à Violência Doméstica pela Fundação Abrinq. A obra dissemina a sua experiência com os Pólos de Prevenção.

2004-2005 Início da disseminação da metodologia de implantação de Pólos de Prevenção à Violência Doméstica, com apoio da Fundação Abrinq, junto a 22 organizações da Rede Nossas Crianças.

2005-2007 Continuidade do processo de implantação dos pólos ampliando a ação para a prevenção da violência sexual, iniciando sua supervisão e a capacitação em violência sexual. Também começam a ser realizados mensalmente os Fóruns de Debates sobre o enfrentamento da violência contra crianças e adolescentes. Esta etapa acontece com o apoio da World Childhood Foundation (WCF Brasil). Neste período, inicia-se ainda a parceria com a Secretaria Municipal de Assistência e Desenvolvimento Social da cidade de São Paulo (SMADS) por meio da inclusão de profissionais ligados às SAS regionais, às quais as organizações da Rede Nossas Crianças, que estão implantando os pólos, pertencem.

2006 O CNRVV é convidado pela SMADS para realizar capacitação de profissionais dos núcleos socioeducativos do município de São Paulo em relação ao tema violência doméstica e sexual . As ações de prevenção, como desdobramento dessa capacitação, continuaram sendo acompanhadas em 2007.

2007 O CNRVV passa a integrar a Comissão Municipal de Enfrentamento à Violência, Abuso e Exploração Sexual contra Crianças e Adolescentes

Tendo em vista a dificuldade de identificar, encaminhar e acompanhar crianças ou adolescentes em situação de violência doméstica, o CNRVV desenvolve atividades de formação, a fim de que os profissionais de diversas áreas e instituições sejam sensibilizados e mobilizados em relação a esse tema e disponham de instrumentos para romper o pacto do silêncio que muitas vezes envolve esse tipo de situação e colaborar no rompimento do ciclo de violência.

Para tanto, o Centro desenvolve um curso de aperfeiçoamento em violência doméstica, numa visão transdisciplinar, destinado a profissionais que trabalham ou 
queiram trabalhar nessa temática; assim como programas de capacitação de profissionais de diversas áreas; palestras, oficinas, congressos e jornadas, em que são debatidos o compromisso dos profissionais com o enfrentamento da violência doméstica, orientações para diagnóstico e entendimento do fenômeno e medidas de enfrentamento.

O CNRVV desenvolve também pesquisas junto às diferentes áreas de trabalho com objetivo de aprimorar a metodologia de intervenção e enfrentamento da violência doméstica, visando a produção de conhecimento que permita superar o senso comum, a abordagem moralizadora e normativa do fenômeno, podendo assim produzir metodologias específicas para essa prática. As pesquisas se referem às áreas de atuação da instituição: sobre o tratamento, em relação ao perfil dos personagens envolvidos na violência doméstica e formas de intervenção; sobre a prevenção, em relação ao perfil dos atendidos e grau de eficácia das intervenções realizadas. Há em andamento uma pesquisa, em parceria com UNICEF, sobre "Sistemas de notificação e detecção da violência em escolas públicas / Propostas para integração entre projetos políticos, pedagógicos e o sistema de garantia de direitos".

Em relação às Parcerias e à Divulgação, o CNRVV investe numa ampliação e fortalecimento de parcerias, visando uma Rede de Serviços que cubra as diferentes e complexas exigências de atendimento e encaminhamento da criança/adolescente "vitimizado", de sua família e do agressor. E, em busca de maior agilidade e rigor nos procedimentos necessários à proteção da criança e do adolescente, e para uma articulação mais estreita com a rede de serviços, o CNRVV integra diversas redes e campanhas, como: Rede de Apoio de Pólos Nacionais Lacri, Campanha pela abolição da punição corporal de crianças e adolescentes no Brasil, Comissão Estadual de Enfrentamento à Violência e Exploração Sexual contra Crianças e Adolescentes, Frente Parlamentar de Enfrentamento à Violência e Exploração Sexual contra Crianças e Adolescentes do Estado de São Paulo, dentre outras. Ressalta-se que o Centro participou da elaboração do Plano Nacional de Enfrentamento da Violência Sexual contra Crianças e Adolescentes, em 2000, a convite do Ministério da Justiça.

O CNRVV atua também na reivindicação de equipamentos de assistência e educação para retaguarda de encaminhamentos de casos mais graves; realiza ações integradas numa comunidade a fim de gerar políticas públicas; realiza fóruns mensais de debate como estratégia de sensibilização da rede de parceria; dentre outras atividades de divulgação do trabalho. O CNRVV conta com publicações de reflexões sobre teoria e 
prática da quebra do silêncio na violência doméstica e sobre a implantação de pólos de prevenção.

O financiamento é composto por recursos governamentais (por exemplo, da Prefeitura de São Paulo, via SMADS) e não governamentais - com Instituto WCF Brasil, Fundação Abrinq, UNICEF, dentre outros. A busca por financiamento é constante, a fim de garantir a autonomia financeira do CNRVV e a sustentação do trabalho em equipe na área de tratamento e capacitação continua dos profissionais.

\section{2. perfil da equipe do centro e das vítimas atendidas}

A equipe do CNRVV conta com dezesseis profissionais ${ }^{93}$ : dois do serviço social, doze da psicologia e dois da psiquiatria. Não há advogados na equipe do Centro.

Foram entrevistadas oito profissionais, todas mulheres. Metade delas com idade entre 25 e 45 anos, algumas (5) com pelo menos um filho. A maioria das entrevistadas não estudavam naquela época e aquelas que estudavam, faziam cursos relacionados à temática do trabalho realizado no centro. Metade das entrevistadas eram formadas há mais de 15 anos e na trajetória profissional de todas entrevistadas há um curso sobre violência doméstica; a maioria delas estagiou ou trabalhou com tema da violência e/ou com crianças e adolescentes na área social. Seis das oito entrevistadas trabalhavam no CNRVV há mais de cinco anos e seu ingresso se deu por convite.

A motivação dessas profissionais para esse trabalho é variada, mas se apresenta no interesse pelo tema da violência doméstica e sexual, pelo atendimento clínico (fora do consultório tradicional do psicólogo), pelo trabalho social / prevenção aliado ao trabalho clínico, pela "diferença" que se faz para a pessoa atendida.

\footnotetext{
“(...) tudo o que eu não tinha imaginado é isso aqui, mas é legal você saber que tem poucas psicólogas que gostam de trabalhar com isso porque não é legal, é aqui dentro, não é nada fora daqui. Aqui tem muita burocracia por ser um trabalho que não deveria ter tanto, pelo papel, tem muita questão jurídica que não tem nada para você fazer, só que quando você está aqui dentro e uma criança te conta uma coisa não tem preço, ai você fala: "Nossa, faz uma diferença!" (E2)
}

Em relação à atividade principal e à descrição do dia-a-dia, as entrevistadas responderam o questionário indicando sua formação e as atividades desenvolvidas interna (em geral indicando a forma de atendimento realizada) e externamente (por exemplo, consultório particular)

93 Dados de acordo com o site institucional, disponível em: http://www.sedes.org.br/Centros/cnrvv.htm (acesso em 10/01/08) 
Em relação aos fatores com que elas se sintam satisfeitas com o trabalho, surge em quase todos questionários o resultado ou evolução do caso atendido, a contribuição da profissional na mudança verificada na pessoa atendida ou na comunidade com a realização do trabalho. A satisfação parece estar atrelada a uma certa verificação de alterações no modo de viver da vítima:

"Ver as pessoas na comunidade poderem se unir, se articular, se fortalecer, reunir grupos para reivindicações, ou se fortalecendo em relação as suas questões de cidadania, se ver como um cidadão ali podendo participar de coisas que antes ele achava que só outro podia fazer que ele não teria acesso nem o direito, é o outro sempre que tem, ele não, por uma série de motivos. Então isso é muito gratificante quando você vê as pessoas podendo circular, ir para outros espaços porque você vai vendo o quanto a pessoa vai ficando refém às vezes devido a sua educação, o seu medo, o seu grupo.” (E6)

"eu acho que a maior satisfação é essa, é você sentir que está fazendo a diferença na vida de uma pessoa quando ela está muito mal, que ela precisa ser ouvida. Muitas vezes ela é muito julgada pela própria família, não tem apoio nenhum, e ela vem aqui, descobre que tem muitas pessoas com esse problema dela, que tem alguém ouvindo poder ajudar e fazer a diferença, essa é a grande motivação." (E2)

“(...) [a satisfação] é ver como de fato as pessoas conseguem refletir sobre coisas já conhecidas e fechadas para eles e de repente poder fazer uma mudança em relação a isso, uma transformação de como vê a sua relação com o outro, o que ele faz com o outro, o que o outro faz com ele e ai poder fazer diferente daquilo que ele estava acostumado a fazer. (...) Poder para e fazer diferente. (...)Você vai perceber que abriu os horizontes, outra realidade diferente da dela. Ver como ela pode sair desse lugar muitas vezes ou de vitima ou de agressor (...). Não ficar com um rótulo, não vira aquela situação porque é muito comum em situação de violência, a pessoa passa a se referendar ou ficar referendado pela situação de violência. (...) É muito interessante como você pode interferir nisso, fazer com que ela possa ser muito mais completa do que simplesmente uma situação que aconteceu com ela e que outras irão acontecer e como é que ela pode se proteger das situações de risco, porque aquela é uma situação de risco sim, uma situação de sofrimento que ela viveu, mas que vai estar cheio de situações de risco." (E6)

"É complicado porque é muito contraditória a satisfação que você tem. Tem coisas que te deixam de fato muito satisfeita, por exemplo, você vê a família entrar no atendimento, uma família que está toda desmantelada, e ela ir se organizando, começar a responder, ter as funções de forma adequada, dando umas escorregadas porque é uma coisa esperada, isso eu acho que é muito gratificante, mas também não é a maioria dos atendimento que desembocam num resultado satisfatório. Então dentro dessa situação toda que a gente vive tem pequenas coisas que acabam dando uma satisfação (...)” (E5)

"Acho que na realidade são pequenas, mas no atendimento elas são muito grandes, acho que é isso que funciona e que faz a gente continuar, sei lá, poder fazer uma diferença na vida deles, não é aquela coisa de atender porque tem que atender. A idéia que a gente tem é de fato trazer uma melhoria de vida para eles, e melhoria de vida no meu entender é uma coisa bem abrangente, não é só atendimento psicológico, não é só atendimento social, não é só atendimento jurídico, é tudo isso, um pouco de colo, um pouco de bronca. "(E5)

Vale ressaltar que nesse item surgiu também um contexto de dificuldades do trabalho: 
"acho que é o mínimo que a gente pode fazer [questionada sobre alguns fatores com os quais se sinta satisfeita com o trabalho], porque há mais dificuldades que satisfação, desculpa, mas é o que você está perguntando..." (E3)

Em relação ao perfil das vítimas atendidas no Centro, é interessante notar que as entrevistadas apresentaram diferentes compreensões da pergunta formulada. Para algumas entrevistadas, o perfil das pessoas que procuram o atendimento no CNRVV é dado pelo encaminhamento realizado, ou pelo perfil psicológico da pessoa atendida, ou ainda pelo tipo de violência sofrida.

Vale mencionar que algumas entrevistadas comentaram sobre a dificuldade de explicitar o perfil das pessoas atendidas e as respostas foram em geral amplas, indicando tratar-se de pessoas de baixa renda, encaminhadas por parceiros e/ou pelo sistema de justiça, moradoras da região norte e oeste da cidade de São Paulo e alguns moradores de outros municípios da Região Metropolitana ou até do interior do estado.

Informações mais precisas sobre situação socioeconômica, gênero, raça, escolaridade, condições de moradia etc, foram remetidas para a assistente social, que seria quem poderia melhor responder a tais questões na equipe. $\mathrm{E}$, de fato, foi na entrevista de uma assistente social da equipe que essas informações foram mencionadas.

Embora os atendimentos sejam majoritariamente de moradores da região norte e oeste da cidade de São Paulo, é possível traçar diferentes perfís de acordo com a localidade. Se na zona oeste da cidade as famílias atendidas conseguem acessar os direitos com mais facilidades, na zona norte há constantemente problemas com falta de vagas em escolas para as crianças atendidas. Em relação à renda, as pessoas atendidas variam desde aquelas que tem renda inferior a um salário mínimo e sobrevivem com auxílio de programas sociais, até famílias que recebem vinte mil reais. Isso ocorre em razão de encaminhamentos para atendimento compulsório no CNRVV, visto que não há um recorte de renda para atendimento no Programa Sentinela, que limita o acesso ao serviço apenas em razão da região de moradia da família.

Quanto ao perfil racial, parece haver uma equiparação entre brancos e negros, mas não fica claro se isso se dá em razão de autodeclaração (pela entrevista, as pessoas parecem se declarar muito mais brancas que negras, ainda que seja afrodescendente para os técnicos). A escolaridade varia entre primário incompleto e superior completo, mas a maioria tem segundo grau incompleto. Em relação ao gênero, as meninas são a maioria em relação às crianças vítimas de violência sexual; e os meninos a maioria quando se trata de violência física. Quanto aos adultos, a expressiva maioria é formada por mulheres, mães. E 
a equipe enfrenta a resistência do homem, em geral pai, em aderir e participar dos atendimentos.

Foi também na entrevista dessa assistente social que outro dado das vítimas atendidas no centro foi revelado com mais detalhes: algumas pessoas são atendidas mediante pagamento, cujo valor é combinado com o serviço social. Os pagantes são, em geral, pessoas de outras regiões não cobertas pelo convênio do Programa Sentinela - seja de outras regiões da cidade de São Paulo, seja de outros municípios do estado. O dinheiro recebido desses usuários pagantes é revertido em vale-transporte para aqueles que não conseguem arcar com os custos de transporte para os atendimentos, visto que o convênio do Sentinela não cobre tais despesas.

Curioso notar, a partir dos relatos da equipe entrevistada, que parece ser considerada de menor relevância a condição de vida da pessoa atendida; como se as características emocionais, o tipo de violência relacionado ao caso e a fonte de encaminhamento resumissem o perfil dessa pessoa. Informações como o gênero, a raça, origem regional, história familiar, a escolaridade, a renda, a composição familiar, o local e a condição de moradia foram raramente comentados nas entrevistas, como se tais dados também não fizessem parte da pessoa atendida, vítima ou agressor.

\section{3. descrição do trabalho desenvolvido no centro}

Neste tópico será abordado o trabalho de atendimento desenvolvido no CNRVV, a partir das entrevistas realizadas com os técnicos da instituição. As demais atividades (como prevenção, formação, pesquisa e parcerias) foram comentadas anteriormente na apresentação do centro.

O primeiro contato com o centro se dá, geralmente, por telefone; nessa ocasião, é realizada uma primeira escuta para verificar se é, ou não, caso do centro. Se o relato não estiver relacionado a uma situação de violência e com o envolvimento de criança ou adolescente, é realizado um encaminhamento para outra instituição da rede para atendimento específico necessário. Se for caso do centro, nesse primeiro contato telefônico é agendada uma entrevista mais detalhada com o serviço social - o chamado "plantão social", que dura aproximadamente 2 horas.

Nesse plantão social, é realizada uma "pré-triagem" em que a assistente social conhece a família, o histórico de violência e, principalmente, verifica se há uma mínima proteção para a criança ou adolescente vítima de violência doméstica. Caso não haja uma 
situação de proteção e houver risco de vida, o serviço social aciona a rede de atendimento para os encaminhamentos necessários. Em razão da regionalização do atendimento coberto pelo convênio com a Secretaria Municipal de Assistência e Desenvolvimento Social para o Programa Sentinela, é feita também uma triagem pelo local de moradia da família e idade dos membros envolvidos. Se não houver cobertura, combina-se o preço do atendimento para os usuários pagantes ${ }^{94}$.

A triagem dos casos é feita em grupos: de pais e responsáveis, de adolescentes e de crianças, divididos conforme a idade ${ }^{95}$. Essa triagem dura aproximadamente quatro encontros ${ }^{96}$ : três para uma "hipótese diagnóstica" e um para uma devolutiva dos casos analisados.

\begin{abstract}
"Eles [os participantes dos grupos de triagem] têm uma idéia de que começou a atendimento e realmente começou, começou uma intervenção, eles se sentem protegidos, às vezes perseguidos, às vezes nem tanto protegidos, mas eu acho que tem essa coisa da função quase que interventiva da própria triagem." (E2)
\end{abstract}

No decorrer desses encontros são realizadas reuniões de discussão de casos com a equipe de triagem e distribuição dos atendimentos conforme disponibilidade da equipe do CNRVV, tentando-se agendar os atendimentos dos membros de uma família no mesmo dia. No caso de crianças e adolescentes em situação de abrigamento, o atendimento é realizado com a criança ou adolescente nos grupos, e o educador do abrigo participa de cursos ou outras formas de orientação para lidar com a situação de violência doméstica e/ou sexual ${ }^{97}$.

\begin{abstract}
"Durante esses três encontros, quatro na verdade, a gente faz uma avaliação e é pensado um projeto de atendimento para essa família. Na verdade, a gente não cuida só da criança e adolescente, a gente cuida da família. Avalia muito essa questão da dinâmica da família e não que a gente tem um agressor e tem uma vítima. Tem a situação de violência que precisa ser cuidada e neste momento temos tais pessoas agredindo, tais pessoas sendo agredidas, mas isso é uma dinâmica muito complexa e que pode mudar também muito rapidamente e até o próprio atendimento vai mudar mesmo. O nosso horizonte é um pouco esse, cuidar de uma dinâmica de violência, e não de pessoas, tanto é que a gente usa o termo vítima e agressor, mas não que este é o agressor e esta é a vitima. É quem está cometendo a agressão nesse momento e quem está submetido à situação de agressão naquele momento. É que é difícil você falar assim, então a gente já fala a vítima, o agressor, o abusador, só para falar mais rápido, mas a
\end{abstract}

\footnotetext{
${ }^{94}$ Se não houver cobertura do convênio SMADS em razão do local de moradia e não for usuário pagante, há voluntários que prestam atendimento.

${ }_{95}$ De acordo com a faixa etária dos adolescentes e das crianças envolvidos em cada processo de triagem, e também conforme a disponibilidade dos técnicos da equipe, são organizados e subdivididos os grupos para triagem.

${ }^{96}$ A triagem costuma durar aproximadamente um mês. Já houve época em que esse procedimento envolvia de 5 a 7 encontros, mas isso demorava muito e os novos casos aguardavam por mais de um mês.

${ }^{97}$ No início, os educadores participavam de atendimentos, mas havia um rodízio entre os educadores e a instituição avaliou que a abordagem deveria ser diferente para as crianças ou adolescentes abrigados, vez que o vínculo dos pais e responsáveis é diferente do vínculo da criança ou adolescente com o educador do abrigo. Por essa razão, os educadores não passam mais por atendimento.
} 
gente tem muito isso como referência, que é uma situação de opressão daquele momento e daquelas pessoas, ou seja, é a coisa manifesta naquele momento. Agora a dinâmica, ou o que a pessoa é, é muito mais complexo do que aquilo que ela está demonstrando naquele momento ou que a gente está podendo ver naquele momento. Tem muito mais coisas por trás." (E6)

A distribuição dos casos é feita para os terapeutas, de acordo com a disponibilidade de horário de cada psicólogo, com a idade da criança ou adolescente, e com o tipo de vitimização. A tendência é que o encaminhamento interno se dê para grupos de adultos (pais e responsáveis), de adolescentes, de crianças ou de agressores; mas também é possível o atendimento individual, atendimento de família e de casal - conforme indicação e avaliação na triagem.

No decorrer do atendimento, os casos são avaliados e a forma de intervenção pode ser alterada para individual ou grupo, segundo a evolução ou resposta de cada pessoa atendida. Há reuniões semanais de discussão de casos e uma supervisão geral.

Ao longo do período de acompanhamento no CNRVV, a intervenção psicológica é mais constante e a assistente social acompanha os casos e intervém quando há necessidade. O serviço social é chamado pelos psicólogos ou pela própria pessoa, mas "depois de um tempo elas passam a procurar sozinhas" (E5). A intervenção do serviço social ocorre quando há algum tipo de entrave no atendimento psicológico - seja por faltas nos atendimentos, seja por alguma questão na escola ou no sistema de justiça - numa abordagem que revela a tensão entre o assistencialismo e a promoção de direitos.

"Porque você também percebe quando é uma coisa [de] bem acomodados, todo dia eles querem uma coisa diferente, [você] faz encaminhamento, [ele] não vai [vão]. Até participar, não ficar esperando cair no colo, porque não é esse o papel, o papel é que elas exijam seus direitos e não ficar[em] [sendo] assistindo[as] no [pelo] resto da vida." (E5)

Além de triagem e atendimento propriamente dito, algumas entrevistadas realizam também outras atividades como docentes nos cursos de formação do CNRVV, atividades de articulação da rede ${ }^{98}$, algumas fazem supervisão para os pólos de prevenção de determinada região (os pólos não fazem atendimento, apenas encaminham para a rede local), dentre outras atividades.

Em relação às demandas levadas ao Centro, a maioria das entrevistadas apontou aspectos individuais e psicológicos, como certa ambivalência entre querer e não querer encarar a situação de violência, ou a tensão entre falar do abuso e a negação ou resistência

\footnotetext{
${ }^{98}$ A articulação da rede é uma das tarefas da coordenação, mas o serviço social também participa dessas atividades, em razão da natureza de seu trabalho (é o serviço social que entra em contato com rede para encaminhamento dos casos) e de maior flexibilidade nos horários das assistentes sociais (por não ter grupos fixos, como ocorre com a maioria das psicólogas).
} 
em lidar com a dinâmica de violência. Foi também indicada a "dificuldade de entrar em contato com as coisas necessárias", ou seja, com a responsabilização 99 pelos fatos ocorridos, pela participação no evento. Muitas relataram a situação de violência doméstica e sexual como a principal demanda: "algum histórico de desagregação familiar, de violência física ou sexual e como eu te disse por encaminhamento ou de Vara ou de busca espontânea ou por intermédio do programa Sentinela" (E3).

Embora a maioria dos casos encaminhados para o CNRVV sejam de violência doméstica sexual (em razão do convênio do Programa Sentinela), há também casos de negligência, abandono, violência física e psicológica.

A conivência com a situação de violência ou o atendimento psicológico também foram notados como demandas, além de queixas para "resolver o problema da criança, e não da família" e pedidos de laudos ${ }^{100}$ para encaminhar ao Judiciário.

Em geral, para as psicólogas a demanda era de atendimento psicoterapêutico, com as nuances conforme o perfil do grupo atendido: se crianças, a demanda em geral era por um espaço de confiança para a revelação do abuso; se grupo de mães, muitas vezes a demanda inicial era pelo cuidado da criança e posteriormente a questão da culpa e a reação da mãe diante da violência - tornar-se superprotetora ou reforçar a vitimização. E no caso de agressores ${ }^{101}$, uma demanda para não reproduzir a violência.

Para o serviço social, a demanda em geral é por inclusão em creche ou em programas de complementação de renda, obtenção de passe especial, questões de moradia e interface com outras instituições como escola, judiciário e conselho tutelar. O trabalho

\footnotetext{
${ }^{99}$ Não se confundindo com a culpa, mas a responsabilização pela participação na situação de violência. Isso foi apontado por uma entrevistada como uma maneira de a vítima se responsabilizar pelos fatos e se tornar "mais sujeito". Mas isso parece curioso diante da violência e violação de direitos sofrida pela vítima, sem questionamento sobre a responsabilização do agressor pelos atos praticados.

${ }^{100}$ No caso de pedidos de laudos, a equipe do CNRVV esclarece o usuário que isso não faz parte do serviço oferecido pelo centro, que presta atendimento às vítimas e agressores de violência doméstica. A busca pelo laudo ocorre especialmente quando a procura é espontânea.

${ }^{101} \mathrm{Em}$ todas as entrevistas realizadas houve apenas o relato do atendimento de uma agressora, que procurou o centro espontaneamente depois de perceber que poderia reproduzir a violência sofrida no passado com um filho mais novo. No decorrer desse atendimento houve acompanhamento por uma psicóloga e foi possível trabalhar um histórico de violências sofridas desde a infância dessa agressora, passando por reproduções de violência com alguns filhos até pedido e reparação com o filho mais novo e com os filhos mais velhos, com os quais a agressora não tinha mais contato e foi possível retomar os laços familiares.
} 
desenvolvido pelas assistentes sociais pode incluir passeios, atividades lúdicas, oficinas temáticas e já uma experiência interessante com a realização de um grupo operativo ${ }^{102}$.

Conforme o pedido formulado pelas pessoas atendidas, vítimas ou agressores, a equipe acolhe ou não a demanda, em consonância com a proposta de atendimento da instituição.

\begin{abstract}
"Eu acho que o atendimento ele não é só psicológico, é uma coisa meio de comportamento, de quais os comportamentos que você pode se proteger, afastar determinadas coisas, impedir, que tipo de brincadeira é aceitável, não dá para aceitar, até para que as crianças possam se defender de situações, porque se a gente parte do princípio que a maioria das situações acontece dentro de casa, se a criança não souber colocar o limite e se defender fica mais dificil, o que a gente tenta fazer é isso. No atendimento de uma forma geral tentar fazer uma coisa de ela se preservar mais, que ela se proteja mais, de como lidar com a situação. O fato de o pai estar assediando não quer dizer que ele tem direito de assediar, ele pode dizer não, ela pode pedir ajuda, ela deve. A coisa da culpa." (E5)

"[a demanda] é uma necessidade de ajuda mesmo para se situar novamente dentro desse drama que elas vivem, e poder ter essa ajuda, no fim elas sabem que vem mais para buscar uma ajuda terapêutica, uma ajuda de orientação mais social." (E7)
\end{abstract}

Nota-se que as principais demandas comentadas pelas entrevistadas se referem à situação de violência de uma forma muito particular, mas ao mesmo tempo genérica. $\mathrm{O}$ aspecto coletivo da violência e de sua dinâmica, apesar de o atendimento ser realizado majoritariamente em grupos, parece pouco visível ou levantado no atendimento. A responsabilização do agressor e a busca por uma justiça sequer foram comentadas como demandas das pessoas atendidas, o que faz pensar que a busca pelo atendimento se dá pela via de uma "solução para o problema da violência" por meio de atendimento psicológico, e raramente social (e nunca jurídico).

Entretanto, se analisarmos as fontes encaminhadoras para triagem e atendimento, a grande maioria é da área jurídica. O Judiciário - Varas de Infância e Juventude, Varas de Família ou Varas Criminais - é a principal fonte de encaminhamento para atendimento no CNRVV, seguido pelos Conselhos Tutelares. Outros encaminhamentos se dão via escolas e creches, núcleos socioeducativos, hospitais, postos de saúde, unidade básica de saúde, delegacias, centros de referência e assistência social (CRAS), profissionais de outras instituições, organizações sociais, pólos de prevenção, além de buscas espontâneas. Os

\footnotetext{
${ }^{102}$ Esse grupo operativo foi formado por mães que aguardavam o atendimento das crianças e não passavam por atendimento psicológico naquele mesmo horário. $\mathrm{O}$ grupo operativo tinha enfoque social e realizava atividades manuais e no decorrer dos trabalhos a questão da violência sofrida emergia e era de certa forma trabalhada pelo serviço social. Algumas participantes que descobriam serviços (como distribuição de medicamentos gratuitos) informavam às demais. Essa experiência de grupo operativo não teve continuidade porque o "serviço social não teve perna para isso e teve que ficar só com uma assistente social".
} 
casos que chegam ao centro espontaneamente não são raros e isso se dá em razão de divulgação do serviço por meio da mídia (TV, internet), via fórum de debates, contato da vizinhança (boca a boca).

Todas as entrevistadas indicaram as Varas e os Conselhos Tutelares como fontes de encaminhamento. A assistente social ressaltou que os equipamentos de educação e saúde encaminham poucos casos para o centro, embora sejam locais que facilmente poderiam detectar casos de violência doméstica contra criança e adolescente.

Embora as fontes encaminhadores sejam diversas, a equipe parece não ter conhecimento preciso sobre isso e sequer interesse sobre cada um dos múltiplos parceiros que compõem essa rede de atendimento. O percurso do caso, antes do encaminhamento ao centro e também internamente, parece ser pouco relevante ao longo dos atendimentos realizados - em que a violência relacionada e os envolvidos nessa dinâmica são pontos centrais (e quase que únicos) nessa intervenção.

\section{4. acolhimento e trabalho interdisciplinar}

Embora considerada relevante, a perspectiva interdisciplinar parece não ser adotada cotidiana e naturalmente nos atendimentos. Em geral, após o questionamento sobre como era o atendimento no centro, a primeira reação foi de uma certa dúvida sobre a pergunta lançada: "como é o atendimento?"; "em que sentido?"; "o atendimento geral ou da psicologia?"; "o atendimento do serviço social ou geral?". Não raramente algumas informações foram remetidas para outros profissionais: "a assistente social pode dizer melhor sobre isso..." e os relatos foram da experiência ocorrida "nos meus grupos", já que "meu foco de atendimento é esse" e "vou falar dos meus atendimentos".

$\mathrm{O}$ atendimento realizado no CNRVV foi relatado pelas entrevistadas de forma generalizada, enumerando os procedimentos envolvidos, com poucos detalhes e descrição do trabalho realizado, ou comentando o atendimento realizado nos grupos e algumas características dos diferentes formatos de grupos - pais e responsáveis, adolescentes, crianças, família etc. Apenas uma assistente social e uma coordenadora de área delinearam o trabalho de acolhimento e diagnóstico desenvolvido ao longo do processo de triagem com mais informações sobre cada um dos procedimentos incluídos nessa fase.

O plantão social só foi explicado pela assistente social e, quando surgiu nas entrevistas, foi indicado, pelas poucas psicólogas que comentaram sobre essa etapa do 
processo de acolhimento, como o momento em que se "recolhem dados" ou que se "preenche ficha".

O momento da triagem ou acolhimento do caso parece ser um dos poucos momentos de fato interdisciplinares. Entretanto, a triagem realizada em grupos é psicosocial apenas para o grupo de pais ou responsáveis, em que há uma psicóloga e uma assistente social na coordenação desses trabalhos. Todos os demais grupos de triagem crianças e adolescentes, divididos conforme a idade - são realizados por duplas de psicólogos $^{103}$.

Ao longo dos atendimentos, a relação entre a psicologia e o serviço social parece ser pouco aprofundada e o trabalho pouco integrado. A interação entre as duas áreas surge quando o atendimento psicológico não evolui satisfatoriamente, seja por faltas, seja por outras questões externas - é o que emerge das falas das entrevistadas:

\begin{abstract}
"Durante esse perído de atendimento que é um atendimento muito mais psicológico, o serviço social entra quando existe alguma crise. Se tudo está perfeito o serviço social não entra, mas se a família começa a faltar ou se tem problema da criança não ter vaga na escola ou não conseguir passar a criança no posto de saúde, qualquer coisa que demande uma articulação com a rede, o serviço social entra e faz os encaminhamentos e também em relação às faltas a gente controla porque se a pessoa não vier, a gente tem que comunicar a fonte encaminhadora." (E4)
\end{abstract}

Assim, é o serviço social que interage mais com os outros profissionais, de dentro e fora do centro, talvez porque acompanhe todos os casos ou pela própria formação. Parece haver mais conversa entre as assistentes sociais sobre os encaminhamentos a serem tomados e os já realizados para discutir se foram adequados ou se outros caminhos seriam possíveis.

"E entre o serviço social também a gente acaba discutindo bastante para ver se
o encaminhamento foi adequado, porque a psicologia trabalha de forma muito
interna, já o serviço social trabalha com toda uma rede, então você não pode
furar, porque senão pode ser que a criança fique sem escola por um mês ou por
um ano. Depende do encaminhamento que você fizer ou que você não fizer então
a gente conversa muito principalmente de todos os procedimentos" (E4)

O trabalho desenvolvido pelo serviço social é considerado relevante pelas psicólogas; mas as questões socioeconômicas das famílias atendidas, que interferem no atendimento psicológico, parecem se referir a, ou ser de competência apenas do serviço social.

"acho até que a gente devia trabalhar mais, porque elas fazem um papel bem fundamental. Aqui elas fazem muito o primeiro contato para mandar para triagem, visitas, quando tem pai ou mãe que não está freqüentando elas mandam cartinha, mas elas poderiam fazer grupos, poderiam ter outras atividades porque eu acho que a gente trabalha com uma população tão carente, que

\footnotetext{
${ }^{103}$ Note-se que a quantidade de assistentes sociais na equipe é bem menor que o número de psicólogos.
} 
carece muito, até questão de higiene, tem gente que a carência é tanta, a criança é tão humilde, mas é tão humilde que ela não entende uma palavra da sua boca, qual é o resultado de uma terapia se ela não tem nem comida, se essa criança no frio vem de shorts e camiseta, são muito pobres, não são todas, uma minoria que é pobre assim, mas tem, essas que você fala: "Se o serviço social tivesse um poder maior, um tempo maior, faria alguma coisa." Tem pessoas que você vê que a condição é muito precária. A criança nem está entendendo, falta de instrução total." (E2)

Embora a troca seja relevante e fundamental para todas as entrevistadas, ainda se sabe pouco sobre a forma de trabalho da outra área, e em alguns casos a troca e interação se mostram quase que desnecessárias.

\begin{abstract}
"Eu não sei como a psicologia faz isso [explicitar os direitos], mas a gente está montando um grupo agora, lá na zona norte, que o serviço social que vai tocar, das pessoas que estão na fila de espera e ai a gente vai discutir essas coisas, a gente está preparando as temáticas, e é em cima dos direitos. (...) mas eu acho que fica muito mais para o serviço social. A psicologia trabalha muito mais as questões relativas do dia-a-dia que a pessoa está trazendo, que perdeu a paciência com a criança e porque isso." (E4)
\end{abstract}

As entrevistas indicam que há um certo distanciamento que é privilegiado pela psicologia e as atividades das diferentes áreas de atendimento co-existem, mas não necessariamente se relacionam ou interagem.

"Existem propostas (...) do Projeto Sentinela que está fazendo oficinas mais amplas, sei lá, levar alguma coisa de lazer, mas ai é uma coisa mais com o Serviço Social e eu não vou dizer que eu sou contra, porque fica feio, mas eu sou muito psicanalista, entendeu, eu acho que se quer fazer beleza, eu não tenho nada a ver com isso, eu tenho que manter uma certa distância, (...) porque senão a coisa fica muito misturada, você tem que manter uma certa isenção de tal maneira que você possa estar o mais próximo possível da dor que aquela pessoa está dividindo com você. Não é que eu sou contra o trabalho, mas é uma tentativa de preservar o meu lugar, de cuidar da minha cabeça, de tal maneira que a minha cabeça esteja da melhor forma possível, que eu consigo no contato com essas pessoas." (E3)

Dessa forma, a interdisciplinaridade não parece ser de fato incentivada. A impressão é de que as atividades são isoladas, algumas iniciativas são incentivadas pelo grupo, mas parecem pontuais e não representam a equipe como um todo.

O trabalho interdisciplinar surge nas entrevistas como uma das diretrizes do trabalho, mas ainda raramente concretizado. A tendência é um isolamento entre as áreas e pouca apropriação sobre o trabalho do outro. O Serviço Social cuida das questões "externas" - como relação com o sistema de justiça, com a escola, com as ausências nos atendimentos psicológicos - e a Psicologia tem atribuição de lidar com as questões internas, psíquicas dos pacientes. E a instituição parece não investir suficientemente nessa troca e interação, não obstante os esforços e procedimentos adotados para esse fim. Exemplo disso pode ser notado nas falas das entrevistadas sobre as fontes de encaminhamento para o serviço: embora todas tenham citado o Judiciário, pouco se sabe 
sobre cada um dos diversos parceiros que encaminham as vítimas para o atendimento no centro.

\begin{abstract}
"Na verdade acho que muitas vêm pela Vara. Como é feita a triagem no atendimento com Serviço Social, quando vem para mim eu nem sei, às vezes eu até leio, mas não é um costume que eu guardo, eu guardo mais o caso, a violência, porque cometeu, porque é isso que eu vou atender. Na hora que eu atendo, ela vem ela já passou por um serviço de triagem, pelo serviço social, então já tem um percurso aqui dentro." (E2)
\end{abstract}

Mas a conversa e a troca entre os técnicos faz mesmo diferença para a vítima? É relevante, para a vítima, ter diferentes formações no atendimento?

"Acho [relevante para a vítima ter diferentes formações no atendimento] porque você tem que pensar neles como um todo. Não dá para você pensar só no atendimento psicológico porque não vai resolver a situação de violência porque a violência não tem uma característica só psicológica, tem toda uma questão social e não adianta você responder só social e não trabalhar a questão psicológica. Então essa parceria é fundamental" (E4)

"Isso [diálogo entre os técnicos] é relevante! Tem que ser. Na verdade, isso é unânime na equipe. Acho que não existe um trabalho em equipe se não tiver efetivamente essa equipe pronta e junta para se ouvir, para trocar, (...) Se não tiver essa troca, a discussão de caso, se não tiver esse compartilhar, entender o que está acontecendo... então não é um centro de referência à vítima de violência; então cada um fica no seu consultório atendendo individualmente." (E1)

A relevância de um espaço de discussão e troca é unanimidade. Semanalmente há uma reunião de discussão de caso e uma vez por mês há supervisão ${ }^{104}$ com um profissional externo. Mas isso ainda se mostra insuficiente no cotidiano da instituição e alguns casos são mais investidos e debatidos que outros:

\begin{abstract}
“tem a supervisão (...), que eu acho que não é suficiente porque é uma supervisão que é uma vez por mês, para a gente estar discutindo casos, e às vezes você precisa de um atendimento mais individual Algumas pessoas aqui fazem terapia, eu faço porque não dá conta, é uma carga muito pesada então eu acho que deveria ter um outro suporte, acho que deveria ter supervisão institucional e não só a supervisão de caso." (E4)

"A gente não tem um espaço [para discussão e troca entre os profissionais] (...) agora tá começando a supervisão (...) de novo, a idéia é que tenha uma coordenadora de atendimento, ter esse espaço que é fundamental é uma das prioridades para esse ano acho que vai ser possivel, a gente já teve mais, mas nos últimos dois anos não teve muito espaço. Então era assim: quem quer escreve na lousa caso tal, fala sobre esse caso, mas se você tem um caso que está mais ou menos, o caso fica prejudicado, não dá para falar de todos, somos em 15, se cada um discutir um caso por dia esquece, a gente vai ter ficar aqui 8 horas só falando sobre isso, é impossivel." (E2)
\end{abstract}

Como o espaço institucional para a discussão de casos com a equipe é insuficiente, e não dá tempo de debater os casos mais complexos na reunião semanal, a troca ainda se dá muito nos corredores...

\footnotetext{
${ }^{104}$ Algumas entrevistadas indicam que essa supervisão mensal é clínica e institucional, outras que é apenas clínica.
} 
"Eu acho que a troca da equipe é muito boa. Toda segunda feira a gente faz reunião que eu acho que agora é pouco para o número de casos porque a gente está com zona norte e zona oeste. Então antes era só zona oeste e já tinha essa reunião, agora a gente pegou zona norte e continua só essa reunião. Então os casos são muitos e quando não dá conta da gente discutir em equipe o que acontece muito são as discussões paralelas” (E4)

"Sempre vem os psicólogos para fazer alguma discussão, não necessariamente na reunião, então até em hora de almoço ou quando eu estou fazendo alguma coisa, vem discutir o caso quando não dá tempo de discutir na reunião. Às vezes a gente junta o serviço social, o psicólogo que está atendendo o responsável e quem está atendendo a criança também ter uma conversa porque às vezes não dá mesmo tempo de fazer isso na reunião." (E4)

Embora a importância da troca entre as áreas da psicologia e do serviço social tenha emergido em todas as entrevistas, muitas vezes essa troca ainda depende muito do caso em questão e dos profissionais envolvidos. A equipe interdisciplinar é fundamental e quase uma exigência para trabalhar com o tema da violência, mas a instituição parece investir pouco em espaços para essa troca.

\begin{abstract}
"não dá para imaginar que uma área possa lidar com tamanha complexidade ou uma família que tem tantas demandas mesmo, até porque ela é multicausal, ela tem que ser multiatendida, vamos dizer assim. E com esses profissionais não é só multi no sentido de ter várias, mas que tem vários que se conversam que são articulados pode ter intervenções (...) Porque se as pessoas não se falarem a gente fica falando de uma família que tem uma dinâmica (...) de puxada de tapete e não é só dela não, é dela e de quem está com ela. Então assim, criar uma dinâmica de violência não só na família, mas rebater isso para os profissionais é uma questão até de perfil ou de característica, isso rapidamente cai na cabeça dos profissionais. E se os profissionais não estiverem muito bem articulados, fazendo um trabalho em conjunto, eles vão se colocar também numa questão de conflito, de briga, de quem é o melhor, quem é o pior, quem passa a ser vítima, quem passa a ser o agressor, você que ferrou com a família, eu que ferrei e não sei o que, quer dize eu que ferrei não quer falar, é sempre você que ferrou. Mas, é isso, rapidamente uma dinâmica de violência se reproduz na própria relação com os profissionais. " (E6)
\end{abstract}

Mas essa construção interdisciplinar ainda é um desafio cotidiano e a relação entre os técnicos ainda se mostra um tanto isolada e com pouca interação.

\footnotetext{
"Você quer que eu ponha um adjetivo, tipo é bom ou ruim? [em relação à troca entre os profissionais de diferentes áreas] Eu acho que justamente porque a gente sabe da importância um do outro, é respeitoso, mas eu acho que às vezes a gente tem que discutir um pouquinho, por exemplo, sobre algumas iniciativas, porque algumas iniciativas eu acho que algumas iniciativas devem ser do Serviço Social e não podem estar misturadas com as iniciativas da psicologia", (E3)

"discute na reunião geral, eventualmente na supervisão, mas acho que assim, são pontos de vista diferentes até porque as pessoas têm formações e propostas diferentes e ai a gente vai fazendo, vendo e construindo, mas a gente não tem uma coisa pronta, se eu disser para você que está pronto, que tem que ser seguido, que tira isso de letra, eu vou dizer para você que não é contundente, mas se eu disser para você que é super hiper amistoso também não é porque a gente pensa diferente." (E3)
}

Embora o diálogo seja fundamental, a ética da profissão nem sempre estimula uma troca de saberes. 


\begin{abstract}
"Eu acho muito legal, a gente consegue falar abertamente sobre essas coisas com a equipe e sobre todo atendimento, o que não foi legal, a gente consegue, dá briga, mas a gente consegue falar e eu acho que sempre quem sai ganhando é o usuário, apesar da psicologia às vezes querer colocar uma coisa de separar, a gente já teve essa discussão. Será que é legal para o psicólogo da criança saber o que a mãe fala ou vice-versa, será que não contamina porque se você vai a um consultório particular, a pessoa que está atendendo a criança não vai conversar com o terapeuta do pai para saber, para confirmar se as histórias são reais, então isso é complicado para psicologia, tem toda uma questão ética. Mas como a gente está em uma instituição e a gente está trabalhando a questão de proteger aquela criança isso tem que ser maior do que esse compromisso ético da psicologia, a gente tem um compromisso muito maior em defender. A gente tem quer verificar sim o que a criança está falando, se a criança fala que continua sendo abusada, como que essa psicóloga não vai conversar com a psicóloga da mãe para verificar, entendeu." (E4)
\end{abstract}

E a instituição nem sempre consegue dispor de mecanismos para favorecer esse diálogo e troca entre as disciplinas. Os espaços garantidos para investimento no contorno interdisciplinar do atendimento às vezes nem sempre são propícios para uma interação com foco no atendimento da vítima de violência.

"Não tem resistência [da equipe para discutir], mas, por exemplo, o viés do supervisor é esse [ética da psicologia] porque ele é psicanalista, então quando ele está dando a supervisão, eles tem que apontar isso. A gente tem que fazer uma decisão e tem que saber se está focando o atendimento, e se for o atendimento não importa se eu termino de atender a criança e ela vai ser abusada. Ele fala que isso não importa. Você não tem que verificar se isso é verdade ou não é, você tem que trabalhar com aquilo que ela está trazendo, se ela está inventando ou se ela não está você trabalha com a mesma proporção, mas não dá para ser desse jeito você falando em defesa de direitos. Não tem como, pelo menos eu penso assim. Então a posição é fechada, porque o trabalho é feito dessa forma, você sabe que quem é da área de psicanálise não concorda muito apesar de fazer dessa forma, mas não tem discussão de mudar isso, não pode." (E4)

"O engraçado é que tem uma base teórica forte de dizer porque você não pode trocar, mas eu acho muito dificil” (E4)

Se internamente verificamos certa fragmentação, a relação entre as instituições é constante, mas parece ser "burocrática" no sentido de receber os encaminhamentos e informar os procedimentos tomados e eventual desligamento à fonte encaminhadora. As entrevistas indicam pouca ênfase na troca de informações sobre o histórico da família atendida, seu percurso por outras instituições, os principais entraves enfrentados nos encaminhamentos já realizados anteriormente e o projetos futuros.

\footnotetext{
"acho que é todo um vínculo de você precisa alimentar, não é uma situação que, por exemplo, eu não vejo as pessoas com muito tempo para ficar consultando essas parcerias, esses contatos, agora pra gente é fundamental, as discussões e tal, porque a evolução do caso acaba, se for ver, todo o percurso do caso, desde que apareceu flagrante, a delegacia, o B.O., o exame no IML e tudo vai desaguar no atendimento e vai ficar mais tempo aqui e é aqui que precisa ter as mudanças a longo prazo e para garantir essas mudanças a longo prazo a gente tem que chamar os parceiros que atenderam o caso, que atendem ainda e fazer a realimentação da dinâmica toda porque senão o caso esbarra em algum detalhe técnico por ai de outra área e não evolui." (E7)
} 


\title{
Embora a relação com as instituições parceiras seja fomentada, a equipe
}

\author{
entrevistada considera o atendimento multidisciplinar, às vezes interdisciplinar, mas com a
} intenção de que seja transdisciplinar.

[se o atendimento é inter, multi ou trans] "boa pergunta, provocativa também (...) a gente troca, mas a gente troca assim sabe, a psicologia com... sabe, não tem uma coisa de uma rede, com judiciário, com assistente social, com psicologia, com psiquiatra, tudo junto, isso não tem. Tem profissionais de psicologia, dois ou três assistentes sociais e aí a gente se vira. Nada mais.” (E2)

"A gente faz discussão de caso: "Olha gente eu tenho um problema, tal e tal, o que a gente pode fazer." Não, então vamos mandar uma carta, aí entra a assistente social, tá bom, então eu mando a carta, entendeu? Mas é isso" (E2)

"Como que acontece [a troca entre os técnicos]? Tem as conversas paralelas, que aqui tem uma abertura, mas isso é uma questão mais individual, ai se for pensar na instituição tem as reuniões com supervisão de grupo, que acabam fazendo uma intermediação, tem (...) a coordenadora dos atendimentos, também para que a gente possa estar direcionando, então tem alguns espaços, no final do ano passado fomos para Cantareira para passar um final de semana, para discutir, para tentar pensar em algumas coisas, acho que sim, acho que se tenta, claro que a questão da interdisciplinaridade não é uma das questões mais fáceis que se tem, mas me parece que dentro do que é possível se está buscando." (E8)

"Acho que o inter é o ideal, o ideal a gente pensar no atendimento interdisciplinar. Pelo menos na minha vivência, talvez na triagem, que tem uma psicóloga e assistente social, talvez se possa falar em inter, mas na minha, é mais uma assistente social que fez uma triagem social inicial e depois eu faço atendimento, então eu vou fazer uma troca mais no grau multi, talvez pensando nos grupos que fazem a triagem, ai sim, ai talvez tenha um movimento inter." (E8)

"Depende. Muitas vezes ele é trans, outras vezes inter e poucas vezes multi. A gente tenta trabalhar dentro de uma transdiciplinaridade o mesmo foco, mas com olhares diferentes para aquele mesmo ponto e que tenha uma ligação, uma discussão, mas às vezes a gente acaba meio que puxando o saco, mas acho que nessas ocasiões [as reuniões] a gente consegue fazer a junção dessas partes e ter um olhar coletivo." (E5)

“A gente consegue e eu acho que particularmente o serviço social é muito respeitado pelo pessoal da psicologia, não tem essa coisa de aqui é minha área, aqui é sua. A gente tem uma relação muito boa nesse sentido, de repente eles pedem visita, ai a gente conversa: "Porque vocês querem visita? Qual é o objetivo da visita?" A visita é super importante, mas ela tem que trazer alguma coisa para o caso senão não tem porque ir lá, eu posso só perguntar. Muitas vezes eles são super convincentes com o que eles acham que é importante, eu quero me assegurar de que é isso mesmo o objetivo. Como a gente também às vezes sugere mudança de terapeuta, de horário, em função de atender uma demanda que é da criança que está difícil de conciliar tudo para a mãe, ou às vezes a criança tem uma atividade escolar que é super importante também, para ela faltar é complicado, a gente liga na escola conversa e tal e traz essas informações. A relação da equipe é tranqüila, o trabalho é muito legal, claro que tem umas épocas mais dificeis, mas isso faz parte da vida e a gente consegue lidar com isso." (E5)

"Eu acho que ele tem o nome de multi, tem a intenção de ser, mas a gente ainda não conseguiu por tudo que eu descrevi. Tem uma conversa de segunda feira e conversa nos corredores, mas o atendimento, a psicologia faz o dela, o serviço social faz o dele. É em função do mesmo paciente, mas não é um atendimento junto, às vezes ele pode acontecer. Como na triagem no grupo de pais, eu acho que ele é multi, mas depois tem todo procedimento e quase sempre ele é inter. 
Ao não ser quando aconteceu de ter grupo de família, e fazer serviço social e a psicologia. Acho que o ideal seria em todos os grupos ser acompanhados por serviço social e psicologia, a não ser quando é um grupo de familia que está discutindo só questões mais relativas a psique, a dinâmica mesmo da família ou quando é individual porque o individual é mesmo uma terapia, mas quando é em grupo eu acho que o serviço social poderia participar e acho que não participa porque a gente não tem condições de ter tantos profissionais assim, mas eu acho que seria muito interessante, porque nos grupos que já aconteceram dessa forma eram grupos muito bons porque a pessoa vinha para discutir uma questão que era social, mas a psicologia já pegava o que tinha dela, eu acho que esse é um trabalho multi. O que acontece aqui não é." (E4) ${ }^{105}$

O ideal transdisciplinar é incentivado pela instituição. As estratégias comuns são definidas em maratona anual - uma espécie de seminário interno em que a equipe se reúne um período para planejamento e reorganização das áreas. Há coordenação de atendimento, que garante as discussões de caso com a equipe e supervisão mensal.

\begin{abstract}
"o ideal seria ele ser transdisciplinar, mas acho que no momento a gente ainda está caminhando para isso, eu vejo mais assim como inter ainda” (E7)

"Porque que não temos essa situação do parceiro e também a nossa de estar numa freqüencia maior do que seria necessária, porque são muitos casos, são mais de cem casos por semana que a gente tem, então a centralização é assim, você tem esse foco num caso muito intenso e dali você tira o aprendizado pros outros, mas garantir que tenha todas as parcerias em todos os casos sempre nesse fluxo e também garantir essa transdisciplinaridade em todos é impossível, por enquanto, e a gente vai tendo uma coisa maior de discussões, mas acho que dentro do necessário acho que isso é feito” (E7)

"Acho que em nível das capacitações, em nível dos trabalhos de prevenção até posso dizer que é transdisciplinar, mas no atendimento ainda estamos caminhando para chegar lá, acho que é inter. Não sei se estou sendo muito pessimista, mas acho que é algo que a gente precisa garantir porque são muitos casos, a maioria dos terapeutas tem de 10 a 20 casos, então é muita coisa para..., mas assim ainda tem uma freqüencia de relatórios de atendimento, tem uma pesquisa que é feita em cima dos dados que acontecem, mas para poder fazer a interação de todos os parceiros de cada caso, da maioria dos casos, é bem complicado, até por questões práticas mesmo, mas os casos que são eleitos, escolhidos, até pela demanda ou urgência, acabam tendo essa reunião essa troca acho que dai a gente consegue, não idealmente." (E7)
\end{abstract}

Mas esses investimentos não são suficientes diante de outras questões mais estruturais, como a composição da equipe e o viés da supervisão institucional.

"Não tem ainda nenhum investimento nisso [momentos de discussão coletiva em
que vocês tentam traçar esse atendimento com essa característica
interdisciplinar], eu percebo que essa é uma demanda de vários porque às vezes
a gente começa a discutir caso e fala: "se você estivesse no meu grupo isso teria
sido resolvido e não foi." E agora você precisa fazer um atendimento individual
dessa pessoa para resolver isso e depois outra pessoa do grupo aparece com a
mesma demanda. Então é muito mais conversa de corredores onde eu já
identifiquei que outras pessoas acham que seria interessante principalmente
para grupo de responsável, eu não falo para grupo de criança, nem para
adolescente que eu acho mais difícil, mas no grupo de responsável eu acho que
não teria problema nenhum, o problema é na instituição de falar: "Não, essa
parte é minha, é atendimento terapêutico." Aqui eu acho que isso não tem, mas

${ }^{105}$ Há uma certa confusão entre multidisciplinar e interdisciplinar; mas é perceptível que cada área faz seu atendimento com raras ocasiões de troca e intervenção integrada. 
também não tem uma mobilização para que isso venha a acontecer porque não tem quadro para isso, simplesmente não tem quadro." (E4)

As discussões de caso são importantes, mas não parecem ser uma oportunidade de apropriação do caso pela equipe ${ }^{106}$. As diferentes formações são fundamentais para o trabalho desenvolvido, mas nem todas as áreas parecem ter a mesma "importância". 107 Embora a orientação seja para a transdisciplinaridade, o atendimento se apresenta com algumas poucas iniciativas interdisciplinares, que dependem mais dos técnicos envolvidos e do caso em questão, que de iniciativas da própria instituição.

\section{5. dificuldades}

As dificuldades do trabalho mencionadas pelas entrevistadas podem ser agrupadas em três grandes temas: a) condição e estrutura de trabalho (que inclui questão da remuneração, espaço, financiamento da instituição, continuidade do trabalho e voluntariado, formação da equipe e modelo do convênio); b) tema do trabalho e suas implicações - violência e vítima: impotência diante da gravidade das situações, condições socioeconômica e familiar, demanda jurídica, observação de resultados e "evaporação" dos casos; c) relação do CNRVV com outros serviços: a formação da rede de atendimento, falta ou inexistência de alguns serviços, fraco contato com escolas e outras instituições públicas.

Em relação às condições de trabalho e infra-estrutura, a questão do financiamento dos projetos e remuneração dos profissionais foi bastante comentada. Alguns profissionais chegaram a trabalhar voluntariamente durante meses, o que não apenas prejudica o atendimento prestado, como também desvaloriza o profissional que lida diariamente com as dificuldades inerentes ao próprio trabalho de atenção às vítimas de violência. Durante os intervalos entre convênios, os profissionais continuam o atendimento, com as mesmas exigências do trabalho, mas sem remuneração nenhuma.

\footnotetext{
"Bom, eu acho que eu posso te dizer que o trabalho não é o que eu gostaria de vivenciar, mas infelizmente é o trabalho, então assim, a gente vive tendo que correr atrás de projeto disso, projeto daquilo outro para gente se manter trabalhando aqui, para ter uma continuidade, porque você tem que ter dinheiro. Por acaso, o povo da minha casa come, a gente tem que pagar as contas (...)" (E3)
}

\footnotetext{
${ }^{106}$ A coordenação geral faz triagem para acompanhar os casos, mas discussões da equipe também não possibilitariam isso?

107 Perguntadas sobre quais as áreas de atendimento da instituição, algumas entrevistadas apontaram o atendimento clínico, prevenção, formação, pesquisa; outras comentaram que comentaram sobre a psiquiatria e sala de espera, além das modalidades de atendimento clínico psicológico. O serviço social não foi citado por essas entrevistadas.
} 


\begin{abstract}
"são grandes desafios, na verdade, eu particularmente, trabalhei durante muito tempo como voluntária. Os convênios sempre pingam, quando tem convênio tem convênio, quando não tem convênio, a gente continua atendendo; então isso é um desafio, mesmo quando tem convênio. A questão do salário que se paga a nós os profissionais que lidamos com isso, o nosso salário também é um desafio." (E1)
\end{abstract}

O modelo dos convênios também não facilita os encaminhamentos de questões inerentes ao atendimento às vítimas de violência, especialmente em relação a demandas jurídicas e relacionadas à saúde mental ${ }^{108}$. Vale ressaltar que o formato do convênio do Programa Sentinela prevê a contratação de um assistente social, um psicólogo e educadores sociais - sem a previsão de um advogado, psiquiatra e outros profissionais importantes no atendimento, na visão dos técnicos do centro; além de não prever verba para algumas atividades que levem em consideração diferenças regionais e da estrutura familiar dos atendidos, como visitas domiciliares.

\begin{abstract}
"a questão da grana é um desafio, porque a gente trabalha com convênio e então a gente também tenta ir atrás de captura de recursos, e apresenta projetos via FUMCAD, via Petrobrás, via nãoseioquelá e a gente vai tentando via SMADS, a gente vai tentando de um jeito ou de outro, mas é um desafio também, não é fácil; a equipe não tem outros profissionais, porque esse convenio que nós temos, são só esses profissionais, não pode contratar outros profissionais, não pode contratar advogado, não pode contratar um psiquiatra, então é toda essa dificuldade também, é um desafio." (E1)

"As principais dificuldades eu acho que são essas, é você ser um modelo meio que fechado que vem pronto de x funcionário, de x criança, $x$ isso e $x$ aquilo. Isso é uma das grandes dificuldades porque as características dos trabalhos daqui são diferentes das caracteristicas do trabalho de outro Sentinela até por conta da regionalização. Você sente como as pessoas são diferentes em cada região, a demanda diferentes. O formato desse quadradinho acho que é uma das dificuldades (...)" (E5)
\end{abstract}

O próprio tema da vítima de violência se mostra um desafio. A dificuldade de adesão e problemas relacionados à freqüência dos atendidos foram mencionadas por quase todas as entrevistadas.

As vítimas atendidas parecem "evaporar" constantemente dos atendimentos. Algumas justificativas são dadas pelas próprias entrevistadas: a dificuldade da própria pessoa atendida de se comprometer e "encarar" as feridas e a situação da violência; falta de compreensão da necessidade de acompanhamento mesmo quando os "sintomas desaparecem"109; o caráter compulsório do atendimento e a dificuldade de vínculo entre

\footnotetext{
${ }^{108}$ Não se questiona aqui se a equipe deve ser ampliada para a inclusão desses profissionais, ou se a instituição deve se articular para fortalecimento de rede de encaminhamentos para as questões jurídicas e psiquiátricas, dentre outras. Nesse momento, apenas ressaltamos a dificuldade apontada pela equipe entrevistada em relação aos encaminhamentos e a insuficiência de respaldo da própria instituição para essas demandas.

${ }^{109}$ Não raramente os pais (geralmente é a mãe quem acompanha os filhos nos atendimentos) interrompem o atendimento quando a criança ou adolescente "melhora" e não apresenta mais os sintomas de abuso sexual. Os profissionais alertam para a possibilidade de recaída e a importância da continuidade do atendimento.
} 
profissional e atendido; dificuldades financeiras que de certa forma podem ofuscar uma questão mais oculta em relação à auto-estima e "capacidade de sustentação" da própria pessoa. Muitas vezes se "justifica” a passividade da mulher diante da violência doméstica pelo viés financeiro; entretanto, em diversos casos é a própria mulher que já sustenta a casa e o homem continua na casa, mesmo sem emprego. Nesse caso, o aspecto financeiro encobre uma outra questão: a auto-estima dessa mulher e sua capacidade de sustentar-se, não mais financeiramente, mas com autonomia, com condições de prover suas necessidades, proteger-se e de proteger os filhos ou quem estiver com ela.

Em geral essa situação de violência não é recente na história familiar dos envolvidos; os vínculos familiares são frágeis e a violência é reproduzida ao longo de gerações. O isolamento social e familiar das vítimas de violência - características das famílias com histórico de violência doméstica sexual - dificultam o trabalho de identificação e encaminhamentos da situação de violência. Foram também mencionadas questões relacionadas à dinâmica familiar e ao rompimento de determinados modelos de vitimização, assim como dificuldades em relação à (falta) de proteção da família em relação à criança vitimizada.

\footnotetext{
"Então assim, é uma coisa muito maior que a gente tem que analisar, não é tão simples a gente culpar essa mãe. São grandes entraves e a questão da coisa de ser muito sigilosa que eu acho que é o maior entrave do trabalho como ela consegue ser da familia, responsável pela proteção é um segredo que tem que ser preservado a sete chaves, então quando isso vem à tona essa violência já está ocorrendo há algum tempo, não é uma coisa recente. Acho que isso também é uma das grandes dificuldades do trabalho, e outras coisas que acontecem políticas mesmo, mas isso não é do nosso trabalho, acho que é de forma geral." (E5)

"é a dinâmica abusiva instalada dentro dessa família, por mais que eu entenda, racionalmente, a teoria, eu entendo o que acontece, eu acabo me identificando muito com os meus pacientes, com as crianças que eu atendo. Então isso é uma dificuldade muito grande para mim...” (E1)

“... a única certeza quando eles chegam aqui é que aquilo não tem jeito porque ninguém deu jeito, os outros profissionais não deram jeito. Então a gente está falando de pessoas com uma auto-estima muito prejudicada, vamos dizer, e que vão contribuindo para que isso seja alimentado (...) é ciclo que vai se repetindo em todo lugar que essa pessoa está, então na hora que você consegue de alguma forma interferir, e que a pessoa consegue sair disso, desse desamparo de nada é possível, nada vai acontecer, e às vezes deixar na mão do outro a resolução disso, ou a potência para a resolução. Mas normalmente o que acontece só muda de pessoa porque ela sai dessa e vai para outra que ela também procura uma proteção, mas ela vai buscar uma proteção nos mesmos moldes da que ela tinha anterior." (E6)
}

A violência estrutural na qual as vítimas (e todos nós) estão inseridas também é uma dificuldade apontada pelas entrevistadas. O trabalho em si apresenta uma 
complexidade singular, inerente ao tema das vítimas de violência. O próprio trabalho é encarado como um desafio diário.

\begin{abstract}
"acho que cada caso é um novo desafio. Então assim, o quanto você tem que estar sempre renovando e mantendo vivas todas as suas experiencias anteriores para estar aplicando nesse novo caso, e conseguir olhar para esse e o que esse tem de igual e o que tem de diferente, e isso eu acho que é bastante cansativo. Ao mesmo tempo em que é instigante, pois cada caso novo é um caso, também é um negócio assim que te dá um pouco uma sensação de que não tem fim. Aquela coisa assim, de novo e de novo e de novo, então é isso, é um trabalho instigante e extremamente estressante, ao mesmo tempo. Não sei se te ajuda." (E3)

"Nossa, eu tenho desafio o dia todo. Todo meu atendimento é um desafio. Acho que o trabalho, esse trabalho é um desafio, atender a criança vítima de violência doméstica é um desafio, porque é tudo tão frágil, é tudo tão incerto, é tudo tão inseguro (...) Então é um desafio constante; um desafio assim, essa criança estar integra emocionalmente, a gente tentar fazer com que essa criança consiga essa integridade emocional é um desafio, que essa mãe consiga esse equilibrio psíquico é um desafio, para poder proteger essa criança, fazer com que o agressor entenda e não abuse de novo é um desafio; então tudo é um desafio, tentar uma vaga pra um atendimento psiquiátrico num posto da UBS é um desafio; tudo aqui a gente se depara com um desafio, tentar convencer a professora e a diretora da escola que tenha um olhar diferenciado praquela criança porque ela ta numa situação complicada da vida dela. (...) mas tentar fazer com que a escola entenda um pouquinho, um pouquinho não muito, é um desafio; fazer com que a mãe venha e trague a criança, não falte, é um desafio; são vários desafios, são vários." (E1)

"Eu acho que os desafios resumindo, a pessoa assumir sua participação na situação, seja ela como vítima ou como agressor e aí de fato ela poder fazer uma transformação dessa situação e sair de um lugar ou de outro e não estar em nenhum desses lugares. Você pensar numa relação sem esse modelo de violência com valores absolutamente naturalizados, essa sexualização nessas relações de infância, de adolescência, das músicas, das roupas. Acho que tudo isso de uma forma é resultado e contribui para reprodução da violência, para que ela continue." (E6)
\end{abstract}

A impotência diante da gravidade das situações de vida das vítimas de violência, a precariedade das condições socioeconômicas de algumas famílias atendidas, falta de respaldo para responder a demandas jurídicas, o desconhecimento dos resultados do trabalho e a falta de aderência e "evaporação" das pessoas atendidas são as principais dificuldades, relacionadas ao tema do trabalho e suas implicações, mencionadas pelas entrevistadas.

\footnotetext{
"Acho que cada um quer fazer o melhor, ter dado conta da situação e é nesse momento que se perde, se ferram e ferram com a família o que é pior, não dá conta e ferra com a família, mas o não dar conta inclui o outro e para incluir o outro quer dizer que eu não dou conta sozinho. A dificuldade que é você poder assumir que você tem limite sim, porque a situação é altamente limitante, entendeu. Só que isso bate numa coisa sua chamada onipotência porque você não quer lidar com a sua impotência e que você não dá conta e que você precisa de ver se o outro pode auxiliar nisso. E muitas vezes a família te põe nesse lugar, de o todo poderoso, para te puxar o tapete logo na seqüência, porque senão não estaríamos falando de uma família em situação de violência." (E6)
} 
Por fim, a necessidade de uma rede de atendimento multidisciplinar, com o envolvimento de todas as áreas necessárias à atenção à vítima de violência, mostra-se como o principal desafio desse trabalho.

\begin{abstract}
"o pacote chega de um tamanho, quando você vai abrir é muito maior do que aquilo que aparece e você vai precisar de alguma coisa que dê sustentação. (...) Acho que essa dificuldade de ter uma sustentação para essa família para que ela possa avançar e sair daquela crise é dificil, e isso eu acho que é um dos maiores desafios para quem trabalha com violência. É um trabalho que você não consegue fazer de uma forma isolada, não adianta eu ser uma ótima psicóloga, psicoterapeuta, sei lá, o raio que for, só cuidar da parte emocional não dá conta de uma série de outras necessidades que essa família tem." (E6)
\end{abstract}

O problema da formação e fortalecimento da rede é uma dificuldade constante nos atendimentos às vítimas de violência. A retaguarda da rede, nas mais diversas áreas, é fundamental, mas ainda uma dificuldade cotidiana. Alguns serviços não existem, ou quando existem não há vaga, ou não há condições de acesso (transporte, tarifa etc.); os serviços mudam com freqüência e alguns contatos são pessoais e pouco institucionais. Aliado a essa questão, há uma dificuldade em relação à condição interna da vítima de sustentar os encaminhamentos e o desenrolar dos atendimentos - às vezes há bons encaminhamentos a serem feitos, mas a pessoa não se mostra apta a seguir as orientações dadas e serviços oferecidos.

"Esse é um grande desafio porque é um trabalho que tem muitas demandas, não é só uma, ou é psicoterapia, ou na área social, é um monte de coisas, e como tem isso principalmente nessa coisa mais pública mesmo, de relacionar essa rede, uma rede acessível, (...) às vezes o serviço não é distante da casa dela, mas não tem uma condução que vá para lá, ela tem que ir até o centro da cidade para depois voltar e chegar naquele serviço e às vezes se tivesse uma condução ela gastaria 10 minutos e ela vai gastar 3 horas entendeu para chegar até o atendimento. Já está numa situação de precariedade, como é que ela vai sustentar tudo isso entendeu, tudo isso que é demandado dela. Ela não tem estofo, condição interna de sustentar tudo isso, porque até se tivesse, talvez não estivesse nessa situação de violência. Mas, ai está tudo tão difícil, a pessoa meio que vai desistindo, ai junta com uma auto-estima baixa, ela já acaba com tudo que chega para ela e ela acaba com as outras pessoas também. É aquela puxada de tapete constante, às vezes você até tem coisas maravilhosas para oferecer, mas a pessoa não tem condição de aproveitar aquilo, então ela vai naquela coisa de puxar o tapete dela e de quem está com ela. Vai fortalecendo até... Aproveitar o que está sendo oferecido, às vezes não tem mesmo, mas às vezes tem e a pessoa não consegue." (E6)

"A questão de encaminhamento, a falta de recurso para encaminhamento, mais do que a falta de encaminhamento eu acho que a constante mudança. Você tem que estar sempre atualizando os encaminhamentos. Eles mudam, fecham os lugares. A falta de recurso também, falta de existência do serviço, acho super grave, você faz os encaminhamentos e não tem resultado e muitas das pessoas têm a ver com a questão habitacional porque foi alguém do mesmo quintal que abusou ou é da casa da frente e a criança mora na casa dos fundos, tem uma proximidade muito grande que isso para criança é terrível porque ela sente uma sensação de impunidade em relação ao cara e muitas vezes não acontece nada porque eles não levam a frente, não vai lá, não faz a queixa, não abre um processo e são processos que dependem do responsável para ser aberto, ou ao 
menos que o responsável seja conivente, ai é Vara, conselho, mas caso contrário, quando acontece no mesmo quintal que é um tio, e a criança está protegida, o que resta fazer é responsabilizar, mas nem sempre está preparado para fazer isso. É um processo, mas é difícil principalmente quando a violência acontece dentro da família porque ai não foi um estranho, quando acontece com estranho é engraçado porque a primeira coisa é ir à delegacia, com a família é mais difícil porque rolam um monte de coisas que é fácil da gente entender primeiro para que essas pessoas possam levar a frente, chegar lá e falar: "Não é nada disso, me enganei" volta atrás, aí não vai dar penalidade nenhuma mesmo." (E5)

Outras dificuldades são relacionadas à rede de atendimento na qual o CNRVV se encontra inserido e o fraco contato com escolas e outras instituições públicas. Em alguns casos, como em relação aos conselhos tutelares, o contato pessoal é privilegiado em detrimento aos encaminhamentos institucionais; em certas circunstâncias, o encaminhamento sequer é realizado por risco de vitimização secundária. Os encaminhamentos jurídicos são os mais complicados em razão de escassez de locais para atendimento jurídico nessa temática.

\footnotetext{
"Eu acho que a questão da rede, principalmente na parte jurídica. Primeiro que a gente não tem um advogado, eu acho que isso é uma dificuldade, mas ao mesmo tempo quando você recorre, (...) ele não dá. Então é muito questão da rede, a gente não tem suporte nenhum jurídico. Não existe isso na rede, então tem que se virar, se você conhece um advogado você pergunta. Não tem, essa parte é zero." (E4)

"E a parte também de atendimento em conjunto com o Conselho Tutelar é dificil porque às vezes eles nem sabem mesmo o que fazer com aquela situação, às vezes eles encaminham uma família para cá, mas eles já fizeram um atendimento que destruiu mais a familia. Às vezes a gente precisa de alguma coisa que seria o Conselho que teria que ir atrás, mas às vezes a gente não passa porque o Conselho pode piorar. A gente acaba juntando um monte de tarefas, a gente vai atrás de qualquer direito que a pessoa tem se acha que foi violado a gente vai. Isso seria o Conselho Tutelar, isso não é o nosso foco, mas se a pessoa já está numa situação que foi tão violentada que a gente às vezes não envia a não ser que a gente conheça o conselheiro. O Conselho nunca é, você conhece um conselheiro de um lugar, aí você pode encaminhar. Com a Vara a gente tem uma relação mais ou menos, eles encaminham e depois a gente pede cópia de processo e eles enviam, se a pessoa não está vindo e foram eles que encaminharam, eles vão atrás e tal, mas a gente também tem problema às vezes. Por exemplo, de uma criança estar em atendimento aqui durante quatro anos, nesse periodo a criança está abrigada e foi desabrigada sem que a gente tenha sido comunicada, então não teve tempo de trabalhar com a criança o desabrigamento. Então problemas com a rede sempre." (E4)

"acho que tem a questão também da justiça, às vezes você pensa de um jeito e a justiça toma uma outra medida e você tem que lidar com isso, às vezes uma criança que não quer ir pro visitário, tem uma determinação de uma visita, $e$ você no dia seguinte atende essa criança "eu não vou pro visitário, eu não quero ir pro visitário", mas a mãe é obrigada a levar pro visitário, acho que essa é a maior dificuldade, lidar com isso porque claramente para a criança ela não está querendo, para ela não está bom, acho tem toda uma organização jurídica, acho é um dos maiores entraves." (E8)
}

Por outro lado, o sucesso dos casos depende desses contatos interinstitucionais. As dificuldades apontadas se inter-relacionam na medida em que algumas questões relativas 
ao tema da violência e da vítima podem ser melhor conduzidas com apoio e retaguarda de uma rede fortalecida e integrada, impedindo que determinados riscos sejam suportados pelo técnico, quase que individualmente, e também possibilitando certa mobilização social que favoreça a estabilidade de convênios e financiamento de projetos.

\begin{abstract}
"Acho que as questões de limites, que é uma questão que essas famílias realmente têm muita dificuldade de respeitar, então trabalhar às vezes com a dinâmica do agressor, com o restabelecimento da dinâmica da família em alguns momentos do atendimento fica complicado porque você às vezes é chamada para fazer depoimentos, ir nas varas, para fazer relatórios e o agressor está sempre ali na mira, qualquer coisa ele processa, então a gente tem um trabalho que proteção que ao mesmo tempo é um trabalho às vezes de duelos, então é um trabalho, uma área de risco e que a gente às vezes também corre alguns riscos, mas é interessante saber que tem e que pelo menos assim, dentro do possivel todo mundo sobrevive. É o nosso grande drama até hoje." (E7)
\end{abstract}

Assim, parece haver uma demanda por maior orientação e suporte jurídicos para a equipe, para minimizar eventuais situações de risco e delimitar alguns limites desrespeitados na dinâmica de violência familiar. Diante de tantas dificuldades, a equipe técnica enfrenta ainda outro desafio: o de manter-se motivada e não reproduzir as dinâmicas de violência e vitimização.

"eu acho que o maior desafio é esse, fazer com que o trabalho seja sempre motivador, porque eu acho muito desagradável trabalhar com essa área e você ser um muro de lamentações, então as pessoas tem que estar sempre trabalhando numa postura mais otimista diante das coisas, acho que o maior desafio é esse, é poder manter uma posição de entusiasmo com a vida, com as coisas, independente de trabalhar com isso, senão você fica uma vitima também, não é verdade?!" (E7)

\title{
3.6. o papel do direito no atendimento às vítimas de violência - vítimas, direitos humanos e casos exemplares
}

O conceito de vítima para a equipe entrevistada passa por uma noção de condição de passividade de um sujeito que, naquele momento ou naquela situação, se encontra sem possibilidade ou condição de defesa ou sem a proteção adequada.

A definição de vítima não foi uma tarefa fácil para as entrevistadas, mas algumas questões foram comuns nas falas das profissionais do Centro: um "estado" de vítima (como uma situação e não uma condição definitiva), a noção de um ciclo ou modelo de violências em que a família inteira se encontra inserida, a desproteção ou sujeição de alguns em relação a outros e o perfil da pessoa como um diferencial nessa vitimização.

\footnotetext{
"Vitima... vítima, eu acho que é a pessoa que não tem ou que está naquele momento sem condição de lidar com uma situação que a faça sofrer... É um conceito dificil esse hein. Acho que é alguém que está sem condição de lidar com uma situação de sofrimento, seja ele físico ou emocional, sem condição de se proteger, ou de lidar, de proteger, de sair... então naquele momento ela está
} 
sendo vítima de uma situação interna e externa, que outro pode estar provocando ou que ela mesma pode estar se causando. Eu acho que é uma falta de condição de se proteger mesmo, de sair de uma situação de sofrimento causada por ela ou pelo outro." (E6)

“É uma fase na realidade porque se você for ver vítima a família inteira é, não é uma coisa que acontece isoladamente, não é a criança que é a vítima, é família inteira. O próprio agressor é uma vítima, então eu acho que é a desproteção na realidade e acaba sendo a desproteção do próprio agressor. Quando você começa a analisar é muito tenso o que é ser vítima e o que é ser agressor num determinado momento, porque aquele agressor foi vitima antes e ele vai reproduzindo. $O$ que eu acho que é o grande valor do trabalho é você romper isso, na hora que você atende essa criança e trabalha essa familia você está rompendo esse vínculo porque senão ele vai ser outro agressor, vai estar repetindo porque é o modelo." (E5)

"É difícil definir vitima porque parece que você está enquadrando e eu acho que ela nem sempre vai ser vítima. Ela é um sujeito e ela está em uma relação e de repente, naquela determinada relação ela pode ser vítima em outra ela pode não ser. Então é difícil você dizer o que vítima porque parece que você enquadra, e ela não vai conseguir dar uma resposta, porque ela está no papel de vítima e ela é sempre vítima. Então eu trabalho muito mais a perspectiva de um sujeito que está na situação de violência, eu não trabalho com a perspectiva de vítima apesar de a gente falar muito, mas quando você pede um conceito não dá porque não é nessa perspectiva que eu entendo, entendo ele como um sujeito." (E4)

Foi também indicado que há vários tipos de vítimas, inclusive de uma violência estrutural, macro. A dinâmica de violência e os papéis exercidos nessa relação podem indicar diferentes situações de vítima e modelos de relacionamento pautados na violência. A relação entre a vítima e o agressor também merece atenção na medida em que a negação da vítima em relação ao agressor surge como uma grande dificuldade do trabalho com a temática da violência doméstica e sexual - o agressor é visto, muitas vezes, como uma vítima que não recebeu os cuidados e acompanhamento necessários, o que implica no risco de uma compreensão quase que conivente com suas atitudes. Essa situação se mostra bastante delicada, pois se trata de uma relação pautada na violência e em alguns casos o modelo de convivência é abusivo ou violento e a vítima não percebe o quanto ela mesma pode alimentar determinadas circunstâncias violentas ${ }^{110}$.

\footnotetext{
${ }^{110}$ Não será tratada aqui a questão da responsabilização do agressor e críticas em relação a punição e tratamento; apenas se ressalta a necessidade de atenção à relação entre vítima e agressor na dinâmica de violência. A análise nesta dissertação é a partir do olhar dos profissionais que prestam atendimento às vítimas de violência e, indiretamente, dessas vítimas. Nesse contexto, é interessante notar que os agressores são vistos como "desprotegidos" na medida em que reproduzem modelos de violência vivenciados anteriormente ou como "tendo razão" na medida em que a vítima permite, de certa forma, que esses modelos sejam reproduzidos. Ao mesmo tempo, há uma queixa da demora ou falta de punição desse agressor pelo Sistema Judiciário. Dessa forma, não obstante a complexidade da dinâmica de violência, muitas vezes essa relação é vista como bipolarizada entre vítima e agressor, e a sobrecarga da vítima é muito maior: além de ser invisível para a maioria das políticas e programas oficiais, ela é quase que culpada pela violência sofrida. (A própria jurisprudência indica esse viés, absolvendo-se o réu em processos de estupro com fundamento na postura e comportamento da vítima, e não do suposto agressor e outras questões. Nesse sentido, ver: Pimentel; Schritzmeyer; Pandjiarjian. Estupro: crime ou "cortesia"? Abordagem sociojurídica de gênero. Porto Alegre, Sergio Antonio Fabris Editor, 1998.)
} 
"A gente fala sempre vítima do outro, muitas vezes a gente é vítima da gente própria, do que a gente vai se tornando, porque senão fica tudo muito dicotomizado, a vítima e o agressor, eu e o outro, e é lógico que esse agressor é sempre o outro, quem causa o dano é sempre o outro, eu estou sempre submetido ao dano que o outro está causando. Então é tudo muito colocado fora e projetado no outro e eu sem nenhuma condição, eu até posso não ter essa condição, mas não está tão na dependência do outro assim, não é o outro que vai mudar e eu vou deixar de ser vítima, que é o agressor sem a vítima? de que agressor a gente está falando? Externo ou interno?" (E6)

Lidar com a vítima de violência é uma tarefa bastante difícil. Todas as entrevistadas comentaram sobre o desafio diante da mobilização interna que cada atendimento provoca e da necessidade de distanciamento e certa separação entre os campos profissional e pessoal para agüentar as tensões entre a satisfação e a angústia, pena e raiva, indignação e envolvimento com o caso.

"Olha, quando eu comecei chegava na minha casa e chorava todos os dias, até que você se acostuma, não sei se existe, até você estar preparada para ouvir o que a pessoa vai te contar" (E2)

"Então assim, é um trabalho de turbulências emocionais grandes, então de alguma forma tem que estar acho que preparada, tem que ter um trabalho interno ou já ter feito terapia ou senão fazer para você poder lidar com essas questões sem reagir no sentido de atuar aquilo que está sendo provocado em você. Mas de uma forma geral essa mobilização é uma coisa assim que acaba eu acho que te fazendo crescer como pessoa e você estar numa equipe e também poder compartilhar isso com a equipe, refletir sobre o que rolou em determinado encontro, como lidar com determinadas situações. Em resumo assim, é um trabalho que é angustiante e gratificante pelo movimento que acontece com você e com a pessoa." (E6)

A trajetória profissional e a necessidade desse atendimento também foram comentadas pelas entrevistadas quando questionadas sobre como é esse contato com as vítimas de violência:

\footnotetext{
"É pesado, mas se você se deixa muito envolver acaba reproduzindo um pouco esse papel de manter as pessoas no lugar de vitimas, de que elas não podem nada. (...) de alguma maneira você precisa aprender antes de dar a resposta, dar o famoso passinho para trás para que você não dê a resposta no mesmo padrão que a pessoa que está ali com você está fazendo. Se você joga uma coisa em cima de mim e eu te respondo de imediato, a minha resposta pode estar sendo igual a sua fala." (E3)
}

Por isso, a necessidade de um trabalho em equipe e espaços de supervisão e discussão de caso, para que os técnicos desenvolvam os instrumentos necessários para o distanciamento exigido pelo trabalho e a carga dessa temática seja dividida e suportada pela equipe. Entretanto, o que se verificou a partir das entrevistas é que esse suporte e o cuidado com a equipe técnica, mesmo reconhecidamente necessários ao trabalho, nem sempre são devidamente oferecidos pela própria instituição - o que sobrecarrega o profissional que lida diretamente com a vítima no cotidiano dos atendimentos. 
A importância do trabalho de atendimento às vítimas de violência é evidente para as entrevistadas: contribuir para a compreensão das dinâmicas de violências e os papéis exercidos, a fim de romper os ciclos e modelos de violência, evitando-se que a vítima reproduza esses modelos apreendidos e torne-se um agressor. Mas esse formato também reflete, de certa forma, esses modelos e ciclos de violência. A relevância do atendimento às vítimas de violência não aparece, nem mesmo para os técnicos que lidam diariamente com essa temática, vinculada aos direitos das vítimas, por si, como sujeitos de direitos ${ }^{111}$. Não foi mencionado e parece não haver clareza sobre existência de normas de proteção às vítimas de violência; a idéia de reparação não é mencionada - com exceção de pedido de desculpas de uma agressora atendida no centro para os filhos vitimizados.

Apesar de todas as entrevistadas considerem que o trabalho desenvolvido - seja de proteção, defesa ou promoção - tenha uma perspectiva de direitos humanos, a percepção dos direitos humanos é pouco elaborada para a maioria dos técnicos e muito relacionada ao Estatuto da Criança e do Adolescente e aos direitos de modo geral.

\begin{abstract}
"A gente fala do ECA, muitas mães aqui sabem da existência do ECA, ou se não sabem chegam aqui e uma conta muito para outra, elas falam muito entre elas, diferentes grupos, conversam mais lá fora do que com a gente, então elas falam muito dessas coisas, dos direitos, da Justiça, o que a criança pode, o que a criança não pode." (E2)

"Bem complexa essa questão do direito. O que é o direito humano? O que é o direito de cada um? (...) É o direito de fazer o que eu quiser, do jeito que eu quiser, como é isso? Ás vezes pode até parecer que você está atravessando o direito da pessoa, o direito que ele tem de funcionar de acordo com o desejo dele, de como essa pessoa se constitui enquanto ser humano porque você está falando de um direito humano. De que ser humano a gente está falando? De como essa pessoa se constituiu, como essa pessoa passa a ser construída entre aspas, enquanto sujeito de direitos dentro de uma sociedade e o que é de alguma forma ou de todas as formas colocado para ele que é o direito dele. (...) Então a gente vai entrando nos direitos e no ser humano socialmente construído. De que direito a gente está falando quando você cai em uma sociedade que diz que os homens têm tais direitos, as mulheres têm outros." (E6)
\end{abstract}

Algumas questões como o direito à informação e desigualdade de gênero foram comentadas; mas não há referência aos deveres específicos dos adultos para com as crianças e nem quanto à interdependência, inter-relação e indivisibilidade entre os direitos humanos. A relação indissociável entre direitos humanos, democracia e desenvolvimento,

\footnotetext{
${ }^{111}$ A importância do atendimento é mencionada pelas entrevistadas relacionada ao rompimento do ciclo de violência, como uma forma de "tratamento" da vítima para que não reproduza os modelos e se torne um agressor. Curioso notar que não surgiu a questão do atendimento da vítima como um direito à reparação, nos termos da Resolução 60/147 da Assembléia Geral da ONU (Princípios e Diretrizes Básicos sobre o Direito das Vítimas de violações das normas internacionais de direitos humanos e direito internacional humanitário a interpor recursos e obter reparações) - vide capítulo 1. A vítima é um sujeito, e não objeto, na dinâmica de violência; é um sujeito psíquico, é um sujeito social, mas não necessariamente vista como um sujeito de direitos.
} 
afirmada pela Declaração e Programa de Ação de Viena em 1993, parece desconhecida ou desconsiderada. Os tratados internacionais e os deveres de respeitar, promover e implementar os direitos humanos assumidos pelo Estado Brasileiro não foram mencionados e aparentemente são ignorados.

Embora considerada importante a explicitação dos direitos humanos, isso raramente ocorre no decorrer dos atendimentos, conforme caso e situação. Essa explicitação das normas se dá principalmente nos pólos de prevenção e nos cursos de formação ${ }^{112}$; mas genericamente em relação aos direitos e deveres e ao ECA. Ora, os direitos humanos não se resumem ao Estatuto, nem mesmo em relação aos direitos humanos da criança e do adolescente $^{113}$.

Não se aborda especificamente os direitos humanos, mas talvez alguns direitos e a noção genérica de uma lei externa à família, uma lei social que imponha limites e parâmetros de valores para os envolvidos na dinâmica violenta. O direito, nesse aspecto, tem um papel de interdição, de impor limites e possibilitar a saída e quebra do isolamento das famílias em situação de violência doméstica; mas insuficiente, para as entrevistadas, sem um atendimento psicológico para que a pessoa compreenda os motivos da atitude tomada e da dinâmica inserida.

Não há advogados na equipe do CNRVV e as demandas jurídicas são encaminhadas para a equipe técnica do Judiciário (também formada por psicólogos e assistentes sociais), que encaminha, quando considerado pertinente, para a Defensoria Pública $^{114}$. As questões jurídicas que surgem nos atendimentos são eventualmente encaminhadas (pelo serviço social, "quando a mãe está preocupada") para assistência jurídica, e há a possibilidade de agendamento de uma reunião específica para

\footnotetext{
112 A equipe entrevistada trabalha nos atendimentos e também nessas outras atividades de prevenção e formação do CNRVV. Mas as questões jurídicas e da violência são trabalhadas por outros professores.

113 Os direitos humanos da criança e do adolescente também estão previstos em diversos tratados internacionais ratificados pelo Brasil, como a Convenção sobre os Direitos da Criança, seus Protocolos Facultativos sobre o envolvimento de crianças em Conflitos Armados e sobre a Venda de crianças, Prostituição e Pornografia Infantis, além de diversas Convenções da Organização Internacional do Trabalho e dos sistema interamericano sobre temas relacionados à infância e juventude, como trabalho infantil, adoção, tráfico de crianças, dentre outros. Além disso, o Estatuto da Criança e do Adolescente é anterior à Declaração e Programa de Ação de Viena de 1993, e a Convenção sobre os Direitos da Criança é mais protetiva que o ECA em alguns aspectos, como em relação ao protagonismo e participação das crianças e dos adolescentes.

114 As entrevistadas comentaram sobre queixas das pessoas atendidas e encaminhadas para Defensoria Pública no sentido de não haver um atendimento mais personalizado e as vítimas não se sentirem muito seguras e respaldadas.
} 
esclarecimento de dúvidas com uma assessoria jurídica para os "casos mais complicados"115. Entretanto, isso não é feito periodicamente.

\begin{abstract}
"dependendo da fase tem muitas famílias que tem dúvidas de assessoria jurídica, tem que comparecer na audiência tal, tem isso, tem aquilo $e$ normalmente a gente faz como se fosse uma maratona, todos se reúnem um $x$ número de mães e chamamos o assessor jurídico para poder ter contato com esses casos e poder encaminhar as dúvidas de todos e na medida do possivel temos parcerias (...) é um trabalho que está sempre revitalizando para eles [as vítimas] serem conscientes e cidadãos, porque se deixar eles não procuram mesmo, então tem que abrir caminhos, tem que favorecer e a gente vê que eles se fortalecem muito, na medida em que sabem que estão amparados, que vão mais preparados para as audiências, tem mães que são obrigadas a ir ao visitário e já estão até enfrentando a ordem judicial porque acham que não deve ir, imagina levar para o agressor ver, coisa de abuso sexual mesmo, então tem casos assim desde os mais leves até os mais pesados, acabam fazendo esse enfrentamento de seus direitos, buscando a sua defesa. (...) A gente já fez maratonas mais seguidas com ele [o assessor jurídico], agora a gente chama quando tem questões mais... a gente espera acumular, para ter uma só rodada." (E7)
\end{abstract}

Na percepção da maioria das entrevistadas, a presença de um advogado na equipe se faz necessária para a defesa técnica, o acompanhamento processual em caso de denúncia, a orientação das pessoas atendidas e a consulta jurídica para os técnicos. A equipe reconhece a necessidade da intervenção de outros profissionais e a ausência de conhecimento técnico jurídico para respaldo necessário nos diversos casos que exigem, pelo menos, uma orientação jurídica.

\begin{abstract}
"as pessoas chegam aqui muito perdidas, não sabem quem procurar. O serviço social acaba fazendo isso, só que às vezes a gente também precisa percorrer um caminho muito longo porque também a gente não sabe, (...) para acompanhamento na Vara Criminal eu acho fundamental porque não tem e as famílias, não são todas, são a minoria que vão e podem, mas essas que querem elas acabam desistindo no meio do caminho porque ela não tem suporte, não sabe o que está acontecendo no processo, não tem acesso ou tem acesso lê e não entende. Acho que para esse acompanhamento para estar esclarecendo, de repente o processo está até rolando, mas a família não toma conhecimento e começa a achar que não está acontecendo nada porque se passaram três anos e ela nunca foi chamada, então parece que nada está acontecendo." (E4)
\end{abstract}

Embora as demandas jurídicas sejam freqüentes nos atendimentos e de certa forma as vítimas fiquem desamparadas para resolver essas questões, a própria instituição parece não se mobilizar para garantir um respaldo jurídico. Não há consenso sobre a importância do atendimento jurídico para a equipe consultada. Para algumas entrevistadas, o CNRVV não se propõe a prestar esse tipo de serviço jurídico e a composição atual - com um conhecimento básico ${ }^{116}$ sobre alguns procedimentos e trâmites legais para

\footnotetext{
115 Outras questões jurídicas ligadas a parcerias, projetos e "a tudo que entra ligado à questão dos direitos, a todo posicionamento" que a instituição precisa ter, passa por um advogado do Instituto Sedes Sapientiae, de acordo com a coordenadora geral do CNRVV.

${ }^{116}$ A presença de uma assistente social com formação também em direito e experiência anterior no judiciário é vista como suficiente para eventuais encaminhamentos de demandas jurídicas.
} 
encaminhamento adequado, somado à assessoria jurídica esporádica (ainda que se espere acumular casos para agendar uma reunião) - tem sido avaliada como suficiente.

Essa aparente desnecessidade de suporte jurídico indica certa contradição entre as falas anteriores que demonstraram as hesitações e os limites da própria lei no decorrer dos atendimentos, por exemplo, em relação à determinação judicial de levar a criança ao visitário e as angústias e conseqüências desse contato com o agressor, assim como quanto à vitimização secundária provocada cotidianamente pelo próprio sistema de justiça. Embora a questão de limites tenha sido apontada como uma das grandes dificuldades do atendimento, apesar de haver uma situação de risco que esbarra inclusive na equipe, a demanda jurídica aparece ofuscada. Ainda que a principal fonte de encaminhamento dos casos seja o sistema de justiça, as questões jurídicas não são trabalhadas ao longo do atendimento e a instituição também não teria como contribuir nesse aspecto. Ao mesmo tempo, a queixa sobre a impunidade dos agressores é repetida pelos profissionais e também pelas vítimas - a responsabilização é encarada como algo externo e independente da vítima que, com exceção da denúncia, não teria nenhuma participação ou contribuição nesse processo.

O Direito não é visto como possível instrumento de intervenção no ciclo de violência - ou melhor, é visto apenas como punição ou como limite ou regra de convivência. As questões jurídicas são, em geral, ignoradas e trabalhadas num viés psicológico e raramente social. A revitimização persistente praticada pelo sistema de justiça não é encarada com um campo de atuação e a instituição, algumas vezes, também mantém a vítima num desamparo para as questões legais ${ }^{117}$.

$\mathrm{Na}$ ausência do Estado, algumas vítimas recorrem ao poderoso local (geralmente ligado ao tráfico e criminalidade) sem se dar conta da gravidade da situação. Uma intervenção jurídica, aliada ao atendimento psicológico e social, poderia contribuir para orientar sobre outras possibilidades de proteção e contribuir para o rompimento de ciclos

\footnotetext{
${ }^{117}$ Em diversas entrevistas emergiu uma revolta das técnicas em relação à determinação judicial de visita da criança ao responsável abusador e os limites impostos pelo sistema de justiça ao desejo da vítima e à angústia e indignação das vítimas e protetores (geralmente as mães) frente a essa decisão judicial de ir ao visitário. A necessidade de lidar com situações semelhantes (determinações judiciais que contrariam ou divergem da diretriz conduzida nos atendimentos) foi apontada como uma das principais dificuldades do trabalho desenvolvido.
} 
de violência e modelos de violência reproduzidos pelas vítimas, às vezes inconscientemente.

\begin{abstract}
“(...) você identifica uma situação de violência, e quando o Estado não consegue dar essa proteção para essa família o que tem acontecido, que eles têm relatado é que essas pessoas vão para o tráfico, para aquele poderoso da comunidade e conta o que está acontecendo. Aí os caras vão lá, os manos e enquadram o cara, oferecem uma proteção para essa mãe, arruma onde morar e não sei o que, só que essa mulher não está se dando conta que ela está saindo de uma situação de agressão e entrando em outra que tem tanto ou maior prejuízo do que ela tinha anterior. Quer dizer está numa situação de proteção e agressão misturadas. E que modelo maluco é esse? Essa mulher que está tão, no caso é a mulher que está nessa situação, o quanto ela acaba repetindo esse modelo porque ela sai de um agressor e vai para o outro e a coisa vai se repetindo, então se não tiver um trabalho, de um atendimento para que ela possa se trabalhar e se conhecer, senão ela só vai mudando de agressor, a proteção e o agressor, não esse tá fazendo isso comigo mas o outro vai fazer diferente, e não muda." (E6)
\end{abstract}

Nesse contexto, a proteção da vítima fica prejudicada diante da ausência de uma rede de proteção real e da complexidade dos dilemas diante dos casos atendidos. Apesar de todas essas questões e necessidades de apoio descritas, é fundamental destacar que o CNRVV desenvolve um importantíssimo papel na luta contra o abuso sexual e contra a violência doméstica contra criança e adolescente, representando uma referência nacional no atendimento e prevenção dessa temática.

Os casos exemplares descritos pela equipe entrevistada apontam experiências de sucesso, seja com a intervenção integrada de uma variedade de serviços, seja com o resultado do trabalho desenvolvido nos atendimentos. Apenas uma entrevistada não indicou um caso específico e afirmou que não há nenhum caso emblemático, tendo em vista que "cada caso é um caso" e todos são demasiadamente "particulares", apesar de haver certas características comuns em termos de dificuldades das pessoas.

Algumas psicólogas comentaram sobre experiências de verificação de resultado do trabalho desenvolvido em intervenções psicológicas. Um bom desfecho com a proteção e alta da vítima que teve sua ferida (física e psíquica) curada como resultado de atendimento psicológico individual; a revelação do abuso por uma criança num espaço protegido com o acolhimento pelo grupo em atendimento psicológico.

A intervenção ágil e efetiva em situação de gravidade e risco, com a necessidade de proteção das crianças inseridas em dinâmica familiar abusiva, num procedimento de triagem também foi considerada exemplar. O trabalho em rede para investigar e diagnosticar uma situação de abuso sexual numa família e para a proteção necessária diante da constatação da violência também foi apontado como bem sucedido, para que os membros da família não reproduzam o ciclo e dinâmica de violência. 
Outro caso exitoso ilustra a intervenção da instituição por meio de diversos dispositivos de atendimento para membros de uma família com histórico e dinâmica de violência doméstica sexual, com mudança dos papéis exercidos pelos envolvidos e a necessidade de apoio e fortalecimento da família para proteção e rompimento do ciclo de violência sem a perda dos vínculos familiares. Esse relato também exemplifica as parcerias com Poder Judiciário, IML, delegacia, núcleo socioeducativo e outros atores; os descompassos entre os procedimentos criminais e de guarda das crianças e adolescentes; falta de informação sobre os direitos e os trâmites judiciais; e a duração dos atendimentos para um resultado minimamente efetivo.

Interessante notar que as assistentes sociais indicaram o mesmo caso como exemplar, o qual aponta diversas deficiências até em relação à repressão da exploração sexual de crianças e adolescentes, crime considerado gravíssimo atualmente. $\mathrm{O}$ abusador era conhecido na comunidade e havia uma resistência inicial da vítima em denunciar oficialmente a situação de abuso ocorrida. No decorrer do atendimento, com o fortalecimento da mãe e da criança, foi feita a denúncia em delegacia fora do bairro, para garantir um espaço protegido e a segurança da vítima.

O relato do caso demonstra todos os impasses envolvidos na situação de abuso e exploração sexual, o desconhecimento dos direitos pelas vítimas, a formação de redes de exploração sexual e o desvendamento pela própria equipe dos trâmites jurídicos para o procedimento de denúncia pela vítima, de forma protetiva, sem um respaldo ou orientação jurídica adequada. Mesmo com o envolvimento da polícia e do judiciário, o procediemnto ainda se encontra em fase investigativa em inquérito policial e não houve ainda uma responsabilização do abusador. Nesse caso houve também uma parceria muito interessante entre o CNRVV e alguns órgãos do sistema de justiça, combinando-se com os funcionários da delegacia o momento de intimação para o depoimento da vítima de acordo com orientação e avaliação da equipe técnica, que preparou a criança para realizar esse depoimento e também para submeter-se ao exame de corpo de delito no IML.

Os casos exemplares apontados nas entrevistas evidenciam importantes resultados do trabalho desenvolvido junto às vítimas de violência, ao mesmo tempo em que nos chama a atenção para a necessidade de apoio e intervenção integrada entre diversos serviços para o sucesso do atendimento dos mais variados casos de violência que chegam ao CNRVV. 


\section{Capítulo 4: O CENTRO DE REFERÊNCIA E APOIO À VÍtiMA (CRAVI)}

No final de fevereiro de 2008 foi realizada uma reunião com a coordenadora do CRAVI e o então assessor jurídico para apresentação do projeto de pesquisa, nessa ocasião fomos informadas da necessidade de encaminhamento do projeto de pesquisa para procedimentos internos de autorização para a realização de entrevistas com os técnicos do centro. Após diversos telefonemas e recados, fomos informadas, em julho de 2008, sobre a necessidade de encaminhamento de um ofício para a Secretaria da Justiça e da Defesa da Cidadania do Estado de São Paulo, solicitando autorização para a realização das entrevistas e contendo informações sobre justificativa, objetivos da pesquisa, métodos a serem empregados, modelo de questionário e roteiro de entrevistas a serem aplicados, assim como uma sugestão do perfil dos entrevistados e a utilização da pesquisa a ser realizada. Tal ofício foi encaminhado ao CRAVI em 29 de julho de 2008, acompanhado do projeto de pesquisa, modelos de termo de consentimento esclarecido, questionário e roteiro de entrevista (vide anexos), assim como uma cópia do texto de monografia sobre o tema ${ }^{118}$. No início de setembro, a realização da pesquisa foi autorizada pela Secretaria da Justiça ${ }^{119}$, possibilitando-se o agendamento e realização das entrevistas com os técnicos do CRAVI.

Foram realizadas nove entrevistas ${ }^{120}$ com técnicos e coordenadores do Centro de Referência e Apoio à Vítima, entre 12 de setembro a 27 de novembro de 2008. As entrevistas foram previamente agendadas, pelo setor administrativo da instituição ou pela própria pesquisadora, e realizadas nas dependências do CRAVI na rua Barra Funda, no Fórum Criminal Ministro Mário Guimarães (Barra Funda) e nas dependências da Defensoria Pública do Estado de São Paulo, também no Fórum Criminal.

As entrevistas seguiram os mesmos procedimentos daquelas realizadas anteriormente: preenchimento de um termo de consentimento e um breve questionário (anexo), seguida de uma entrevista gravada e posteriormente transcrita. Cada encontro teve

\footnotetext{
118 A monografia "Linguagem e efetivação dos direitos humanos: o desafio do Direito no atendimento interdisciplinar a vítimas de violência" foi apresentada em outubro de 2004, como parte dos requisitos para obtenção do título de especialista em direitos humanos, ao Curso de Especialização Lato Sensu em Direitos Humanos da Faculdade de Direito da Universidade de São Paulo.

119 Encaminhado o ofício, foi elaborado um parecer da equipe técnica do Cravi e encaminhado ao setor jurídico da SJDC para os trâmites do procedimento de autorização da pesquisa.

${ }^{120}$ Foram entrevistados dois profissionais de cada área de atendimento (psicológico, social e jurídico), dois coordenadores e a coordenadora geral do Cravi. A entrevista com a coordenadora geral não foi finalizada, mas será utilizada nos tópicos pertinentes.
} 
duração de aproximadamente uma hora e meia. Em razão da agenda de alguns profissionais e de prazo para conclusão da pesquisa de campo, foi necessário remarcar algumas entrevistas e desistir de outras ${ }^{121}$.

A partir do discurso dos profissionais entrevistados, serão discutidas algumas questões sobre o trabalho interdisciplinar desenvolvido, as dificuldades do atendimento às vítimas de violência, direitos humanos, vítimas e ao papel do direito nesse cenário.

\section{1. breve apresentação da instituição: histórico e missão}

O Centro de Referência e Apoio à Vítima - CRAVI - foi criado em 1998. É um programa da Secretaria da Justiça e da Defesa da Cidadania (SJDC) do Estado de São Paulo, em parceria com Secretaria Especial de Direitos Humanos (SEDH/PR), Secretaria de Estado de Assistência e Desenvolvimento Social (SEADS), Tribunal de Justiça do Estado de São Paulo (TJ/SP), Defensoria Pública do Estado de São Paulo (DPESP) e Secretaria de Segurança Pública do Estado de São Paulo (SSP) - Instituto Médico Legal (IML Central).

O CRAVI tem como missão "ser referência para ações e políticas públicas que visem superar os ciclos de violência e promover reconhecimento, cidadania e acesso aos direitos de vítimas de crimes contra a vida, violência doméstica e sexual”122.

De acordo com o site institucional ${ }^{123}$, o CRAVI tem como objetivo "dar visibilidade às vítimas de violência, inclusive aquelas indiretamente afetadas, como é o caso dos familiares de vítimas de homicídio". O objetivo geral do CRAVI é "identificar, compreender e atender as demandas por justiça e direitos humanos. Outro aspecto importante deste trabalho é o seu caráter preventivo, favorecendo alternativas para a vivência da perda violenta e rompendo ciclos de violência".

Os objetivos ${ }^{124}$ do CRAVI são:

\footnotetext{
${ }^{121}$ A entrevista com a coordenação geral do Cravi não foi concluída devido à dificuldade de agendamento e ao cancelamento de parte da entrevista em virtude de compromissos com o Secretário da Justiça. As entrevistas com mais defensores públicos também foram prejudicadas em razão da agenda de compromissos e remarcação de entrevistas.

${ }^{122}$ De acordo com folheto de divulgação do Cravi.

${ }^{123}$ Conforme site da Secretaria da Justiça e da Defesa da Cidadania, na página web sobre o Cravi, disponível em: http://www.justica.sp.gov.br/modulo.asp?modulo=45\&Cod=45 (acesso em 06/01/09). Embora o site esteja desatualizado (não inclui o atendimento a casos de violência doméstica e sexual), consideramos importante ressaltar os objetivos constantes na página eletrônica da instituição.

${ }^{124}$ Conforme http://www.justica.sp.gov.br/Modulo.asp?Modulo=413\&Cod=45 (acesso em 06/01/09).
} 
- "Dar visibilidade à questão dos homicídios nos centros urbanos e às vítimas diretas e indiretas, garantindo-lhes o direito de serem ouvidas, a partir do entendimento de que a morte violenta de um cidadão é uma questão social.

- Divulgar a existência da "vítima indireta", como a nomeação de um dos efeitos da violência fatal, na medida em que tal conceito se refere àqueles que, de alguma forma, sofrem com a morte violenta de algum familiar.

- Compreender o "perfil" da vítima de homicídio: encontrar padrões, mas, acima de tudo, enxergar a complexidade diversificada da violência urbana. Reconstruir a história de vida das vítimas, contextualizando a violência sofrida, a partir do campo individual, mas como um problema social.

- Promover o protagonismo do usuário enquanto sujeito de direitos, em contraponto às ações assistencialistas normalmente vinculadas ao tema da violência, promovendo-o da situação de vítima para a de sujeito de direitos e deveres.

- Mediar o acesso dos usuários às instituições públicas, instrumentalizando-os para o exercício político da cidadania, através da informação, como estratégia para promover a autonomização do usuário.

- Colaborar para a redução da impunidade, auxiliando as vítimas a compreender os procedimentos policiais e judiciais, acompanhando-as nas fases mais importantes dos processos e contribuindo para o esclarecimento dos crimes, através da apresentação de novas informações."

Dentre as ações e atividades ${ }^{125}$ desenvolvidas, destacam-se:

- Prestação de atendimento interdisciplinar (psicológico, jurídico e social) a vítimas de crimes violentos graves e a seus familiares;

- Identificação dos perfis da violência criminal urbana e formas de prevenção;

- Identificação e redução dos efeitos traumáticos provenientes da violência sofrida pelas vítimas e por suas famílias;

- Atuação como auxiliar na ruptura de ciclos e códigos de violência existentes na família;

- Inserção da vítima no processo penal, garantido-lhe acesso à Justiça;

- Apoio e orientação àqueles que podem contribuir como testemunhas para a realização da justiça.

${ }^{125}$ De acordo com: http://www.justica.sp.gov.br/Modulo.asp?Modulo=414\&Cod=45 (acesso em 06/01/09). 
- Atuação no combate elou minimização dos efeitos da vitimização secundária, através de capacitações a agentes do Estado e demais profissionais que atendam vítimas ou seus familiares.

O CRAVI é um serviço público de atendimento às vítimas de violência. Oferece orientação, acolhimento e atendimento social, psicológico e jurídico aos familiares de pessoas vitimadas por violência fatal (homicídio e latrocínio) e às vítimas de violência doméstica e sexual, e também às pessoas que estejam sob risco, ameaça ou que tenham sofrido tentativa de crime fatal. Os atendimentos, sigilosos e previamente agendados, são realizados individualmente, em grupos, com familiares, com crianças e com adolescentes $^{126}$.

Desde sua fundação, o CRAVI se dedicou ao atendimento social, psicológico e jurídico dos familiares de vítimas diretas da violência fatal. Sua atuação foi pioneira em relação à ampliação do atendimento às vítimas - tradicionalmente realizado às vítimas diretas de violência ou de violações de direitos humanos - ao enfrentar o desafio do trabalho de apoio às vítimas indiretas da violência fatal. $\mathrm{O}$ atendimento aos familiares dos vitimados por mortes violentas provocadas por homicídios e latrocínios e aos sobreviventes de tentativas de crimes fatais foi desenvolvido pelo CRAVI levando-se em consideração a complexidade das violências, a banalização da morte, a busca pela justiça, o acolhimento e escuta dos familiares e a elaboração do luto provocado pela morte violenta.

Em 2007 a SJDC inaugurou uma nova unidade do CRAVI no Fórum Criminal Ministro Mário Guimarães e foi ampliado seu foco de atuação, incluindo o atendimento às vítimas de violência doméstica e sexual ${ }^{127}$.

O programa foi criado em 1998 para dar cumprimento à previsão constitucional de assistência às pessoas vitimadas (artigo 245 da Constituição Federal), em atenção também à Constituição Estadual de São Paulo (artigo 278) e ao Programa Estadual de Direitos Humanos (Decreto n. 42.209/97). A composição original do projeto contou com a Secretaria da Justiça e da Defesa da Cidadania (SJDC), Secretaria de Estado de Assistência e Desenvolvimento Social (SEADS), e Procuradoria Geral do Estado de São Paulo

\footnotetext{
${ }^{126}$ Informações de acordo com folder da instituição.

127 Desde 2003, a SJDC mantinha um psicólogo no Juizado Especial Criminal da Família da Capital (JECRIFAM) no Fórum Criminal da Barra Funda, onde eram atendidos casos de violência doméstica e sexual. Com a retomada de um espaço do Cravi no fórum e com a extinção do JECRIFAM em 2007, após a edição da Lei 11.340/06 (Lei Maria da Penha), as demandas relacionadas aos casos de violência doméstica e sexual foram absorvidas pelo Cravi, ampliando-se o recorte do trabalho.
} 
(PGE/SP); em parceria com o Ministério da Justiça ${ }^{128}$ (SEDH/MJ), além de universidades (PUC/SP, por meio do Núcleo de Violência e Justiça da Faculdade de Serviço Social; Faculdade de Psicologia da FMU; Centro Acadêmico XI de Agosto, da Faculdade de Direito da USP); uma ONG: "Pró-Mulher, Família e Cidadania" e o SENAC - Centro de Educação Comunitária para o Trabalho. Posteriormente houve um trabalho intenso com o Instituto Sou da Paz, cujo convênio se manteve até junho de 2003. Outras organizações da sociedade civil também firmaram convênios com a SJDC para execução do trabalho desenvolvido no CRAVI: o Instituto São Paulo contra Violência e o Instituto Therapon Adolescência $^{129}$.

As parcerias firmadas por meio de convênios com organizações nãogovernamentais possibilitavam a execução dos atendimentos com a contratação de profissionais da equipe e supervisão institucional e clínica, além de outras atividades como cursos e remuneração de estagiários. Porém, alguns problemas eram constantemente enfrentados, como a interrupção dos atendimentos em razão de intervalos entre convênios, instabilidade da equipe técnica e as burocracias do financiamento dos projetos.

\begin{abstract}
"Esse ano o CRAVI pela primeira vez, desde a sua fundação há 10 anos atrás, está trabalhando sem o convênio direto no atendimento. (...) Nós tínhamos alguns problemas com isso, passaram algumas instituições ao longo dos anos aqui pelo CRAVI e os convênios eram feitos por um ano e às vezes a renovação desses convênios demorava um tempo, então o atendimento era rompido e isso era muito ruim. Tiveram intervalos de convênios que chegaram a durar seis meses, isso para o usuário que está em acompanhamento é desastroso, então a proposta é que o CRAVI pudesse funcionar com uma equipe fixa para que o usuário não ficasse tão suscetivel assim a essas intercorrências administrativas (...) porém para o CRAVI funcionar sozinho ele tem que aumentar o seu quadro de funcionários" (E9)
\end{abstract}

A partir de 2008, nenhum convênio com a sociedade civil foi firmado para execução do serviço de atendimento na instituição; investindo-se mais nas parcerias governamentais e na ampliação do serviço com a instalação de outros núcleos de atendimento às vítimas de violência na cidade e no estado de São Paulo.

A parceria com a Secretaria de Estado de Assistência e Desenvolvimento Social se materializava na presença de quatro assistentes sociais daquela secretaria para o exercício das funções no CRAVI. Ao longo dos anos os funcionários da SEADS solicitaram

\footnotetext{
${ }^{128}$ Em 1998, a Secretaria Especial de Direitos Humanos era vinculada ao Ministério da Justiça, e não ao Gabinete da Presidência da República como atualmente.

129 O convênio com o Instituto Therapon Adolescência iniciou em 2002, com recursos da SJDC, em razão necessidade de psicoterapia para crianças e adolescentes e para supervisão institucional; em paralelo ao convênio com o Instituto Sou da Paz, para o projeto geral, com financiamento da SEDH e da SJDC, que durou até 2003. Em 2004 tem início convênio com o Instituto São Paulo contra a Violência, mas essa parceria não teve continuidade (dentre outros motivos, pela excessiva demora na prorrogação do convênio). O Instituto Therapon Adolescência manteve convênio com a SJDC até final de 2007.
} 
transferência e foram se desligando das atividades do CRAVI. Em meados de 2008 esse formato de parceria foi finalizado com a transferência da última assistente social do SEADS, a qual trabalhou durante anos no CRAVI.

A parceria inicial com a Procuradoria Geral do Estado possibilitava a presença de procuradores da Procuradoria de Assistência Judiciária para orientação dos usuários no CRAVI. Tal parceria foi interrompida em 2003. Com a criação da Defensoria Pública do Estado de São Paulo, foi firmado um convênio entre a Defensoria e a SJDC, em 2007, para que o atendimento jurídico, desenvolvido até então por advogados do núcleo jurídico do CRAVI, fosse realizado por defensores públicos ${ }^{130}$.

O Governo Federal, por meio da Secretaria Especial de Direitos Humanos, ligada à Presidência da República, é parceiro da SJDC desde a implantação do CRAVI.

No início de 2007, em parceria com a Secretaria de Segurança Pública, foi instalado um núcleo do CRAVI no Instituto Médico Legal Central, com a proposta de realizar um plantão no local na tentativa de abordar as famílias de vítimas de homicídio e latrocínio, no momento da liberação do corpo no necrotério. Entretanto, após alguns meses, foi considerado extremamente difícil tal serviço, pois as famílias se encontravam naquele momento bastante abaladas e não conseguiam ouvir ou assimilar as informações prestadas pelos técnicos. Por esse motivo, foi mudada a estratégia para o envio de cartas de divulgação do serviço oferecido pelo CRAVI e convidando as famílias para atendimento $^{131}$. Essa parceria foi suspensa para reavaliação da proposta e seria retomada no segundo semestre de 2008.

O CRAVI realiza basicamente atendimentos às vítimas de violência, mas também realiza algumas atividades de referência na medida em que realiza palestras de sensibilização sobre o tema da violência fatal, vitimização e atendimento às vítimas para o acesso à Justiça, além de orientar e participar de fóruns de discussão e debates públicos.

Há uma proposta de ampliação do CRAVI com a instalação de núcleos de atendimento às vitimas de violência em outras regiões da cidade de São Paulo e em outros

\footnotetext{
${ }^{130}$ Maiores informações no item 6 sobre o papel do direito no atendimento às vítimas de violência.

${ }^{131}$ As cartas eram enviadas após um ou dois meses da morte e tiveram cerca de $15 \%$ de retorno. Os técnicos que realizavam o plantão no IML tinham acesso às fichas identificadas com homicídio e latrocínio, nos arquivos do IML Central. Inicialmente também eram enviadas correspondências aos familiares constantes nas fichas identificadas com morte suspeita, mas "depois acabaram achando melhor mandar só por homicídio e latrocínio". Após o acidente que matou 199 pessoas, nas proximidades do aeroporto de Congonhas, envolvendo avião da TAM, em julho de 2007, essas atividades foram suspensas para redefinição de estratégias da parceria com a Secretaria de Segurança Pública. Uma das propostas é de extensão desse trabalho de envio de mala-direta nos casos da clínica do IML, abordando também pessoas que passaram por perícias em casos de violência doméstica, violência sexual e tentativas de homicídio.
} 
municípios com alto índice de violência. A estratégia inicial foi de negociação direta com as prefeituras, mas devido a entraves enfrentados, houve uma reformulação da estratégia de ampliação do serviço e a proposta atual é de parceria entre o Estado e organizações da sociedade civil nesses municípios ${ }^{132}$. Havia ainda a previsão de instalação, até final de 2008, de núcleos de atendimento às vítimas em três Centros de Integração da Cidadania (CIC) - em Campinas, Guarulhos e na zona sul de São Paulo (no CIC Feitiço da Vila) - e mais cinco núcleos de atendimento na Grande São Paulo no ano seguinte.

Há também a proposta para 2009 de maior investimento na área de prevenção, com o envolvimento de outras secretarias de governo e subprefeituras da cidade de São Paulo para mobilizar a população para refletir e debater sobre a violência e formas de prevenção.

Quanto à publicações e pesquisas sobre a instituição, em 2002 foi publicado o livro "Reflexões sobre Justiça e Violência: o atendimento a familiares de vítimas de crimes fatais" ${ }^{\prime 33}$, o qual sistematiza os debates travados em seis Oficinas de Imersão Reflexiva realizadas em 2000 sobre temas de relevância ao trabalho do CRAVI, como justiça e lei, judiciário e controle social, justiça popular, vingança e violência.

Em 2003 foi concluída uma pesquisa sobre "Consolidação da Política de Atendimento às Vítimas da Violência Urbana" ${ }^{134}$, baseada na demanda real e na ação articulada entre os diversos setores do Governo do Estado e da sociedade. Tal pesquisa foi financiada pelo Programa de Políticas Públicas da Fundação de Amparo à Pesquisa do Estado de São Paulo (Fapesp) e contou com a parceria da Pontifícia Universidade Católica (PUC-SP). Essa pesquisa contou com duas fases: na primeira fase foi mapeado o local de residência da vítima e o local da ocorrência de mais de três mil homicídios registrados em São Paulo, foram ouvidos usuários do CRAVI e realizada formação teórico-prática de técnicos diretamente envolvidos no atendimento, inclusive profissionais indicados pela rede parceira. Tudo isso pra preparar uma segunda fase da pesquisa, em que foram

\footnotetext{
${ }^{132}$ No momento da pesquisa de campo, aguardava-se a aprovação, pelo Governador, dessa proposta de parceria entre Governo do Estado e organizações da sociedade civil nos municípios de maior índice de violência para instalação de núcleos de atendimento às vítimas. A proposta já havia sido aprovada pela Secretaria da Justiça.

${ }^{133}$ O livro "Reflexões sobre Justiça e Violência: o atendimento a familiares de vítimas de crimes fatais" foi organizado por Isaura de Mello Castanho e Oliveira, Graziela Acquaviva Pavez e Flávia Schilling, publicado pela EDUC e Imprensa Oficial do Estado de São Paulo, em 2002.

${ }^{134}$ Os resultados dessa pesquisa não foram publicados. Uma versão resumida encontra-se na rede interna do Cravi. As informações aqui constantes foram baseadas no site oficial da Secretaria da Justiça e da Defesa da Cidadania.
} 
realizadas visitas e entrevistas aos familiares das vítimas de homicídio em São Paulo, a fim de configurar suas necessidades e desenhar os caminhos da violência. ${ }^{135}$

Essa pesquisa revelou as principais demandas dos familiares das vítimas diretas de homicídio: a grande necessidade de serem ouvidas qualificadamente, em ambiente acolhedor e que ofereça retorno; melhoria na qualidade de vida da região de moradia e consequentemente melhores condições de trabalho, educação, saúde, lazer e segurança. Também foi apontada a demanda quanto à criação de um Centro de Atendimento às famílias das vítimas que preste assistência e apoio, tratamento psicológico, orientação em relação aos arranjos da vida, desorganizados repentinamente em razão da morte violenta, orientação jurídica pronta e clara para buscar a Justiça, e não ter de clamar por vingança.

A pesquisa revelou que ${ }^{136}$ :

- $63,4 \%$ das vítimas nasceram e foram criadas na Capital;

- 96,1\% dos bairros onde moravam as famílias das vítimas não possuíam cinema e 97,6\% não possuíam teatro;

- a maior parte das vítimas tinha entre 18 e 33 anos de idade;

- entre as vítimas, 90,8\% eram homens e 9,2\% eram mulheres; 35,3\% eram brancos e $13,8 \%$ eram negros;

- algozes e vítimas apresentavam um perfil social semelhante: mesmo segmento social; viviam o mesmo movimento de exclusão, as mesmas impossibilidades; moravam na mesma região ou bairro; tinham a mesma idade; morriam na rua, perto de casa, ou em casa;

- entre os que procuraram ajuda, $80 \%$ eram mulheres, sendo metade mães e metade esposas ou companheiras.

Essa pesquisa indicou ainda que o atendimento às vítimas deve ser pautado por compromissos de respeito e sigilo, num ambiente acolhedor para atender esse tipo de violência. As organizações que desenvolvem essa atividade devem promover aos seus profissionais condições de trabalho que contemplem a capacitação técnica, a supervisão institucional e o atendimento qualificado. A construção e reconstrução, de forma sistemática e constante, do perfil das vítimas e da própria violência também foram destacadas.

\footnotetext{
${ }^{135}$ De acordo com livro "Reflexões sobre Justiça e Violência: o atendimento a familiares de vítimas de crimes fatais" e conforme o site institucional do Cravi, disponível em: http://www.justica.sp.gov.br/Modulo.asp?Modulo=411\&Cod=45 (acesso em 06/01/09). 136 De acordo com o site institucional do Cravi, disponível em: http://www.justica.sp.gov.br/Modulo.asp?Modulo=411\&Cod=45 (acesso em 06/01/09).
} 
O serviço de apoio às vítimas de violência oferecido pelo CRAVI foi divulgado no $\mathrm{n}^{\mathrm{o}}$. 202, da série governo e sociedade, do Boletim $\operatorname{DICAS}^{137}$ - Idéias para a Ação Municipal, com informações gerais sobre o CRAVI, objetivos, parcerias, forma de operacionalização e suporte para municipalização desse serviço.

Em 2008 foi lançado o livro "Quebrando o silêncio: memória, cidadania e justiça" produzido pelos participantes do grupo de cidadania do CRAVI, realizado em 2006. Esse grupo foi formado por nove familiares de vítimas de violência fatal e coordenado por duas psicólogas e uma assistente social do CRAVI e teve como produto das atividades desenvolvidas o livro contendo relatos sobre o impacto da morte violenta e da experiência dos participantes.

No momento da realização da pesquisa de campo, havia outra pesquisa sendo realizada pelo Núcleo de Estudos da Violência da Universidade de São Paulo, em parceria com o CRAVI, no projeto "Violência, Risco e Vulnerabilidade: homicídios e violações de direitos humanos em São Paulo",138, com objetivo geral identificar os fatores que constituem as situações de vulnerabilidade dos jovens à violência letal no Município de São Paulo. Essa pesquisa analisará o sentido que a exposição a situações de risco possui na conformação das trajetórias de jovens vítimas de homicídio do Município de São Paulo, a partir da reconstrução da história de vida desses jovens por meio de entrevistas com familiares e amigos atendidos pela instituição.

Atualmente o CRAVI conta com dois endereços: o Centro de Referência localiza-se numa casa na rua Barra Funda e o Centro de atendimento encontra-se numa sala do Fórum Criminal Ministro Mário Guimarães ${ }^{139}$.

O financiamento é público e composto de verbas federais da Secretaria Especial de Direitos Humanos (SEDH/PR) e verbas estaduais da Secretaria da Justiça e da Defesa da Cidadania do Estado de São Paulo (SJDC).

\footnotetext{
${ }^{137}$ O Boletim DICAS - Idéias para a Ação Municipal, é um boletim voltado para dirigentes municipais (prefeitos, secretários, vereadores) e lideranças sociais. Os textos buscam oferecer informações sobre técnicas e práticas de gestão que contribuam para o avanço da democracia, otimização da aplicação e uso dos recursos públicos, promoção da cidadania e melhoria da qualidade de vida. O n. 202 sobre o trabalho desenvolvido pelo Cravi encontra-se disponível em: http://www.polis.org.br/download/arquivo_boletim_70.pdf (acesso em 27/06/08)

138 Dados de acordo com o site do Núcleo de Estudos da Violência da USP: http://www.nevusp.org/portugues/index.php?option $=$ com_content\&task=view \&id=1669\&Itemid=56 (acesso em 06/01/09)

${ }^{139}$ Conforme já mencionado, houve também um núcleo de atendimento instalado no Instituto Médico Legal (IML Central), mas no momento da pesquisa de campo e conclusão da dissertação esse serviço encontrava-se suspenso.
} 


\section{2. perfil da equipe do centro e das vítimas atendidas}

A equipe do CRAVI conta com quatro psicólogos, três assistentes sociais, um assessor jurídico, dois coordenadores e uma supervisora geral, além de três oficiais $\operatorname{administrativos}^{140}$; seis defensores públicos prestam atendimento jurídico em regime de plantão $^{141}$. Todos os funcionários são agentes públicos lotados na SJDC, alguns em cargos comissionados, outros são funcionários públicos concursados.

Até final de 2007, uma parte da equipe do CRAVI era contratada pela organização da sociedade civil conveniada ${ }^{142}$. Com mudança de direção política da instituição, a partir de 2008 nenhum convênio com a sociedade civil foi firmado para a execução do serviço e contratação de profissionais.

Foram entrevistados nove profissionais das áreas de atendimento (psicologia, serviço social e jurídico) e coordenação. A equipe entrevistada foi composta por maioria feminina (6 mulheres e 3 homens) e sem filhos (7). Os entrevistados tinham idade entre 27 e 48 anos e a maioria estudava no momento da entrevista (pós-graduação). Grande parte dos entrevistados (6) tinha formação superior recente (até 5 anos da graduação) e havia lidado em sua trajetória profissional com o tema da violência, ainda que da violência social. O ingresso no trabalho do CRAVI se deu por indicação ou em decorrência de concurso público para a SJDC. A equipe é recente na instituição, quase todos estavam na organização por menos de 5 anos (6 entrevistados trabalhavam no CRAVI há menos de 3 anos).

A principal motivação para o ingresso nesse trabalho foi um pouco variada, mas o tema da violência foi indicado por 3 entrevistados. A temática e a missão do CRAVI, o contexto de acesso à Justiça e o desafio do trabalho também foram apontados como motivações pelos entrevistados.

Em relação à atividade principal e descrição do dia-a-dia, os entrevistados mencionaram a função exercida e as atividades desenvolvidas internamente no programa, como atendimento, reuniões, contatos e formação de rede interinstitucional.

\footnotetext{
${ }^{140}$ Essa era a composição da equipe ao final da pesquisa de campo, em novembro de 2008 . No decorrer da fase de campo, fomos informadas de que em dezembro um dos coordenadores e o assessor jurídico se afastariam das atividades do Cravi. Ressalta-se que nem todos os técnicos prestam atendimento direto à população. Na ocasião da pesquisa de campo, uma psicóloga e o assessor jurídico realizavam outras atividades diversas do atendimento direto.

${ }^{141}$ Até outubro de 2007, eram quatro defensores públicos que prestavam o atendimento jurídico no Cravi em regime de plantão, por um período de 6 meses. Com a reformulação dos termos da parceria entre Defensoria Pública e SJDC, foi ampliado o número de defensores envolvidos para seis profissionais e o período de trabalho para um ano. Veja item 6 sobre o papel do direito no atendimento às vítimas de violência.

${ }^{142}$ Em dezembro de 2007, a equipe era composta por sete psicólogos, quatro assistentes sociais e dois advogados.
} 
A satisfação dos técnicos se refere, em geral, ao atendimento e seus resultados: o fortalecimento do usuário atendido, a construção de possibilidades de mudança junto com a vítima, o próprio atendimento. A sistematização da metodologia de atendimento, como forma de contribuição e referência a outros profissionais, foi bastante comentada nos questionários como indicativo de satisfação com o trabalho. Também foi recorrente o enfrentamento da violência. Alguns entrevistados comentaram, isoladamente, sobre outros fatores como: a discussão em equipe, aprimoramento profissional, acesso à justiça, local de trabalho. Vale ressaltar que a insatisfação com o trabalho também emergiu como resultado da pesquisa - num dos questionários foi indicada a busca por algum fator que possibilite um pouco de satisfação.

Em relação ao perfil das pessoas atendidas no CRAVI, a maioria é mulher ${ }^{143}$, com idade entre os 20 e 50 anos, moradora da periferia do município de São Paulo ${ }^{144}$ especialmente das regiões sul, leste e norte da cidade. Essas mulheres geralmente perderam os filhos (aproximadamente $70 \%$, de acordo com as entrevistas), maridos e companheiros devido à violenta letal. A escolaridade, em média, é de primeiro grau incompleto e a renda dessas pessoas é baixíssima ${ }^{145}$, em torno de um a três salários mínimos, e até famílias sem renda alguma, que sobrevive de "bicos". Alguns entrevistados destacaram que a quantidade de homens que procuram a instituição tem aumentado, independentemente da ampliação do recorte de trabalho.

Quando questionados sobre o perfil das pessoas que procuram a instituição, muitos dos entrevistados comentaram sobre o recorte do atendimento do Centro, indicando como perfil vítimas de violência fatal, violência doméstica e sexual; porém todos os entrevistados souberam indicar minimamente um perfil socioeconômico dos atendidos, ainda que informações mais detalhadas fossem remetidas ao serviço social.

$\mathrm{Na}$ maioria dos casos recebidos pela instituição, a violência fatal foi vivenciada pela primeira vez na família; embora outras formas de violência estivessem presentes no

\footnotetext{
${ }^{143}$ Interessante notar que as vítimas diretas dos crimes violentos são, geralmente, jovens do sexo masculino, que deixaram suas mães, às vezes suas esposas ou companheiras, e fillhos. Mesmo nos casos de violência doméstica e sexual, conforme informações dos entrevistados, a maioria dos atendimentos é realizada com meninas, menores de idade.

${ }^{144}$ Embora o Cravi seja um programa do Estado de São Paulo, a grande maioria dos atendimentos se refere à cidade de São Paulo, o que indica e justifica uma das propostas do Centro de municipalização e regionalização do serviço.

${ }^{145}$ A instituição realiza uma avaliação socioeconômica para fornecimento de passe para viabilizar o transporte das vítimas para o atendimento no Cravi.
} 
histórico familiar, em poucos casos a vítima atendida no CRAVI já havia vivenciado outros crimes fatais na família.

Interessante destacar que alguns dados desse perfil - como a dificuldade da maioria dos usuários em acessar instituições de justiça e de segurança (a falta de referência e de informações para exercício de seus direitos) e a autodeclaração como parda da maioria dos usuários - foram mencionados apenas por um dos entrevistados, o qual participava da elaboração das estatísticas dos atendimentos realizados na instituição. Curioso também que o aumento da procura pelo serviço de pessoas aparentemente psicóticas foi indicado por uma assistente social.

Embora toda a equipe entrevistada tenha comentado sobre o tipo de violência vivenciado e informações básicas sobre gênero, renda e região de moradia, parece haver pouca atenção aos dados sobre a composição familiar, o histórico de violência, a relação com o agressor ${ }^{146}$ e a facilidade ou dificuldade de acesso às instituições públicas. É certo que esses dados dependem das circunstâncias envolvidas em cada caso, porém, essas informações mais sistematizadas poderiam delinear melhor o perfil das vítimas, diretas e indiretas, atendidas no CRAVI - o que contribuiria no aprimoramento do próprio atendimento realizado, uma vez que algumas demandas poderiam ser melhor trabalhadas ${ }^{147}$, além de auxiliar no planejamento de eventual trabalho de prevenção.

\section{3. descrição do trabalho desenvolvido no CRAVI}

$\mathrm{O}$ atendimento às vítimas de violência é o principal trabalho desenvolvido no CRAVI. Há outras atividades desenvolvidas pelos técnicos do CRAVI, como desenvolvimento e fortalecimento da rede de entidades, e o planejamento da instituição de ampliação e municipalização de núcleos de atendimento às vítimas de violência conforme já comentado na apresentação do programa.

\footnotetext{
${ }^{146}$ No caso da violência doméstica, o agressor muitas vezes se encontra inserido numa dinâmica violenta no ambiente familiar; quanto à violência fatal, os autores de crimes contra a vida muitas vezes residem em locais próximos às moradias de suas vítimas, o que pode influenciar mudanças de residência, uma sensação de impotência e impunidade entre as vítimas indiretas. Para maiores informações, ver "Vidas Nuas, mortes banais: os homicídios em São Paulo através da fala de suas vítimas indiretas". Caderno de Resultados de Pesquisa realizada em parceria da Pontifícia Universidade Católica, Centro de Referência e Apoio à Vítima e Secretaria da Justiça e Defesa da Cidadania do Estado de São Paulo, mimeo, 2003.

${ }^{147}$ Uma das questões trazidas pelos técnicos entrevistados foi em relação à dificuldade e/ou desconhecimento de alguns usuários sobre as instituições de Justiça e os trâmites e caminhos para acessar os tribunais; esse dado sobre o perfil dos usuários do Cravi poderia ser utilizado na composição e fortalecimento da rede de contatos da entidade, poderia ser importante para o setor jurídico para melhor orientação sobre os procedimentos envolvidos no caso, para o serviço social traçar os encaminhamentos pertinentes e talvez até para a psicologia no sentido de fortalecer emocionalmente esse sujeito.
} 
O primeiro contato com a instituição se dá basicamente por telefone, embora também possa se dar via e-mail ou presencialmente. Uma equipe de triagem retorna o contato para verificar se o caso é pertinente ao recorte ${ }^{148}$ de atendimento do CRAVI, identificar se há risco de vida ou situação emergencial que exija um atendimento mais urgente, além de agendar o acolhimento ${ }^{149}$, conforme disponibilidade da pessoa e também de vagas e horários dos técnicos que realizam o acolhimento. O tempo de espera entre o contato inicial e esse primeiro atendimento tem sido de um mês e meio a dois meses.

O acolhimento ${ }^{150}$ é a porta de entrada na instituição. É realizado por dois profissionais de diferentes áreas, do serviço social e da psicologia, para uma escuta da vítima a ser atendida no CRAVI. Esse processo dura em geral três a quatro encontros e depende muito das questões envolvidas em cada caso.

Às vezes esse acolhimento pode durar mais, conforme o "estado em que se encontre esse usuário, porque às vezes ele vem um pouco transtornado, com bastante dificuldade de expressar o que ele está querendo, vem com muitas queixas e até a gente conseguir formar uma demanda, tem uma previsão de quanto tempo dura esse acolhimento, mas varia de usuário para usuário” (E10)

O acolhimento tem como função principal possibilitar que a pessoa possa falar e ser escutada sobre a violência vivenciada, o motivo de ter buscado o atendimento no CRAVI e sua demanda inicial. Para que, ao final desse procedimento, seja identificado que tipo de

\footnotetext{
${ }^{148}$ Se a questão envolvida não se referir ao atendimento oferecido no Cravi, a equipe de triagem encaminha o caso para rede de atendimento conforme a questão envolvida. Se houver dúvida, chama-se para o acolhimento.

${ }_{149}$ Termo utilizado pelos profissionais do Cravi para designar o processo de recepção dos usuários no serviço.

${ }^{150}$ Em 2004, o acolhimento também era realizado geralmente em três encontros. Num primeiro encontro, técnicos dos núcleos psicológico e social escutavam principalmente a história da violência fatal e o que motivou a ida da vítima ao serviço. O relato geralmente era bastante emocionado e intenso, rico em detalhes e lembranças - essa carga emocional independia do tempo transcorrido: fatos passados há anos eram revividos com intensidade, pois talvez nunca tinham sido elaborados. Iniciava-se um diálogo baseado no sigilo, confiança e respeito - possibilitando também uma atenção ao caso relatado e uma identificação inicial das demandas apresentadas. A intensidade dos relatos e da emoção era grande e muitas vezes exigia um segundo encontro em que algumas dúvidas poderiam ser sanadas, o diálogo poderia ser intensificado e o pedido trazido pelo usuário poderia ser melhor delineado. Em 2004, esse segundo acolhimento era também realizado por psicólogo e assistente social. A tônica ainda era a escuta, mas com maior possibilidade de intervenção e discriminação dos fatos e relatos, a fim de identificar o perfil do usuário e as demandas trazidas. O terceiro acolhimento era realizado, em geral, por um técnico de cada área: social, psicológico e jurídico. Era o momento em que o advogado entrava para compor o acolhimento e os técnicos apresentavam uma proposta de atendimento às vítimas indiretas da violência fatal, conciliando-se as diferentes áreas. Nesse momento, eram realizadas algumas orientações jurídicas iniciais e era acordada uma proposta de atendimento entre os técnicos e os usuários. Os acolhimentos realizados costumavam ser discutidos entre os técnicos posteriormente, por meio de relatórios dos acolhimentos e de reuniões de discussão de caso e/ou supervisão. Em alguns casos é necessário realizar outros encontros, em continuidade do acolhimento, para que a proposta fosse melhor definida junto com o usuário.
} 
apoio a instituição pode oferecer, numa construção conjunta entre técnicos e usuários de uma proposta de trabalho. Em alguns casos a pessoa busca determinadas medidas que a instituição não pode oferecer e é realizado um encaminhamento para a rede de serviços.

Ao final do acolhimento é definida e combinada uma proposta de intervenção, formulada pelos técnicos em conjunto com as pessoas acolhidas na instituição. Em seguida são realizados os encaminhamentos pertinentes, para a rede (caso a demanda trazida não seja relacionada ao foco de trabalho da instituição) ou para dispositivos internos do CRAVI $^{151}$. A proposta de intervenção é delineada em conjunto pela pessoa que procura o serviço, acompanhada ou não de seus familiares, e pelos técnicos envolvidos no acolhimento, como forma de desenvolver a participação da vítima como sujeito no atendimento. Há um instrumental denominado ficha de encaminhamento interno, onde constam os dados e a demanda que o usuário portou durante o acolhimento e a proposta de atendimento construída nesse processo. Logicamente, o encaminhamento interno definido nesse acolhimento poderá ser reavaliado conforme atendimento e resultados.

$\mathrm{O}$ encaminhamento interno pode ser para as áreas ${ }^{152}$ jurídica, psicológica e/ou social, em atendimentos individuais ou em grupo, familiar, de casal, para crianças, adolescentes e adultos. Os atendimentos podem ser unidisciplinar ou interdisciplinar - seja em grupo ou individual. Há também grupo psicológico e grupo de cidadania.

O trabalho desenvolvido no CRAVI é focado no sujeito atendido, no sentido de olhar e escutar a pessoa, e não simplesmente evidenciar a violência sofrida ou a violação de direitos. A ênfase do acolhimento e dos atendimentos é o sujeito, que tem uma história de vida e sofreu uma violência que o levou ao CRAVI, para a partir daí se pensar e trabalhar as possibilidades após esse fato.

\footnotetext{
${ }^{151}$ É possível também que diversas demandas sejam levantadas no curso do acolhimento e ao final algumas questões sejam trabalhadas internamente no Cravi e outras necessitem de encaminhamento externo, para a rede de serviços.

${ }^{152}$ Conforme documento de apresentação do CRAVI, elaborado pelo coordenador geral à época em 2004, o núcleo psicológico era responsável pelo atendimento psicológico de familiares de vítima de violência fatal e realiza atendimento a adultos, crianças e adolescentes - com foco na elaboração do luto vivenciado de forma violenta, auxiliando na identificação do processo pelo qual o usuário esteja passando e da maneira pela qual se pode evitar que o fato violento venha a se constituir como um trauma psíquico permanente. A apresentação do CRAVI menciona também a possibilidade de evitar a produção de sintomas danosos ao sujeito, assim como o caráter preventivo dessas ações, pois o drama vivido reaparece na forma de doenças, de múltiplos sintomas. O núcleo social teria como objeto de trabalho a violência e a inserção social das famílias, cabendo-lhe a tarefa de compreender e reorganizar, junto com os usuários, a rede familiar e social. Ao Núcleo Jurídico caberia "estabelecer uma ponte entre as instituições formais de Justiça e a família, com o objetivo de decodificar o discurso jurídico para as famílias, permitindo sua inserção e acesso ao processo penal, bem como, promover a realização de alguns direitos, seja através de orientação ou por meio de ações judiciais."
} 


\begin{abstract}
"antes da violência e antes da violação de direitos tem um sujeito que sofreu uma violência, tem um sujeito que sofreu uma violação de direitos (...) Acho que a gente tem desenvolvido uma metodologia para dar embasamento ao que é você considerar esse sujeito antes de olhar para a violação, antes de olhar para o crime, enfim, antes de olhar para essa questão da violência como se fosse descolado ou como se fosse só um sujeito que sofreu violência, é também, mas não é só." (E14)

"O atendimento atualmente está muito focado no desejo que esse cidadão porta na instituição, o quanto ele pode se responsabilizar por aquilo que ele pede, que ele diz que é importante para ele no momento, acho que essa é uma linha condutora dos atendimentos." (E13)
\end{abstract}

$\mathrm{O}$ atendimento psicológico é realizado após uma avaliação psicológica em que é definida a "direção" do atendimento, que deve ser condizente com a diretriz institucional do CRAVI - caso não seja, é realizado um encaminhamento para atendimento externo. É trabalhada a questão da "responsabilização subjetiva sobre a questão da violência", ou seja, a elaboração de luto e de trauma e a possibilidade de reconstruir sentidos para existência.

O atendimento jurídico é realizado pela Defensoria Pública do Estado de São Paulo e consiste basicamente em orientação sobre inquéritos e processos relacionados aos fatos violentos vivenciados, acompanhamento processual dos casos criminais e assistência jurídica em demandas correlatas à da violência, como questões cíveis e previdenciárias.

O jurídico do CRAVI não faz a representação processual das vítimas atendidas na instituição, tal qual um advogado constituído. Mas realiza primordialmente orientação sobre os trâmites processuais e procedimentos judiciais envolvidos no processo criminal os prazos de investigação em fase de inquérito, os procedimentos envolvidos, o andamento do inquérito ou processo - como forma de acesso à Justiça. Em alguns casos é pedido o desarquivamento do inquérito policial para que o usuário seja melhor informado sobre as provas colhidas e possa colaborar caso saiba de alguma informação não constante nos autos. Também é realizado encaminhamento para assistência judiciária em casos de outras demandas jurídicas não relacionadas ao processo criminal, como pedidos de indenização, benefícios previdenciários, inventário, dentre outras.

$\mathrm{O}$ atendimento do serviço social do CRAVI utiliza alguns instrumentais (como estudo socioeconômico, agenda do cotidiano e atendimento) e trabalha no sentido de auxiliar a vítima atendida a localizar seu lugar social, a localizar as redes de relações em que ela se vê inserida e a acessar a rede de serviços nas quais ela pretende se inserir, assim como acessar os direitos sociais, tudo isso para realizar encaminhamentos pertinentes às questões levantadas pelos usuários. 


\begin{abstract}
"no atendimento social, a gente começa a abordar esse sujeito pelo que trouxe ele aqui e isso conforme ele vai falando a gente vai observando então todas as marcas que foram ficando na vida para além de só a violência que trouxe ele aqui. Tem sim uma perspectiva de trabalhar com uma história de vida, mas não uma história de vida que vai sendo contada na ordem cronológica, mas uma história de vida que vai sendo contada conforme o que o sujeito quiser trazer, para a partir dessas marcas que foram ficando a gente ir entendendo que lugares sociais esse sujeito foi ocupando ao longo da sua vida, que lugar ele ocupava na familia dele, que lugar ele ocupou na escola, que lugar ele ocupou no bairro dele, nas instituições que ele freqüentou, o que foi acontecendo, que lugares esse sujeito foi ocupando e como ele está hoje, em que lugar que ele está hoje." (E14)

"Muitas vezes as pessoas vão cada vez ficando mais frustradas e mais deprimidas quando vão buscar ajuda em lugares errados, errados no sentido de que não podem responder aquilo que ela quer, então o serviço social tem oferecido um trabalho assim que é de poder ir construindo com a pessoa qual é a pertinência do que ela quer buscar e em que lugar ela tem que buscar. O que tentamos fazer é com que essa pessoa possa fazer uma mediação entre essas instituições, ela possa fazer essas instituições conversarem também, não só a gente tentar fazer a rede, mas essa pessoa possa ir formando uma rede com todas essas instituições que ela precisa utilizar e tem que acessar.” (E14)
\end{abstract}

$\mathrm{O}$ atendimento psicossocial é realizado quando a demanda social está diretamente articulada ou influenciando a demanda psi e vice-versa.

\begin{abstract}
"Quando a gente acha que a demanda social está diretamente articulada ou influenciando a demanda psi e vice-versa ou quando está um pouco confuso ainda na fala do usuário o que é para uma área e o que é para outra, a gente tende a iniciar o atendimento psicossocial junto e caso faça sentido, separar os atendimentos. A gente já fez tanto isso de separar porque aí ficou muita demanda psi e muita demanda social que não dava para fazer no mesmo atendimento e ficou claro o que era para qual área então a gente separou e teve casos que a gente foi até o final psicossocial porque estavam muito articuladas, as demandas subjetivas com as demandas sociais." (E12)
\end{abstract}

Outro dispositivo é o grupo de cidadania, indicado para as pessoas que tenham interesse em discutir a questão da violência sob a temática da cidadania e da participação política. Esse grupo pode ser coordenado por profissionais de quaisquer das áreas jurídica, psicológica ou social. Esse grupo originou-se de uma experiência em 2004 de um grupo interdisciplinar coordenado por um psicólogo, uma assistente social e uma advogada. $\mathrm{O}$ grupo de cidadania, com duração de quatro meses, teve sua primeira turma em 2006, coordenado por duas psicólogas e uma assistente social; o advogado que atuava na época colaborou na elaboração do projeto, mas não da coordenação dos trabalhos desse grupo. Como produto das atividades desse primeiro grupo houve a publicação do livro "Quebrando o silêncio: memória, cidadania e justiça".

"é um livro de depoimentos dos usuários, onde eles contam um pouco do que eles passaram, do que significou isso para eles, é um livro muito interessante que para os usuários foi muito gratificante pode participar de um trabalho, poder nomear o que estava sentindo e poder escrever sobre isso; e no grupo falando da importância de que aquela dor não fosse só dele, de que aquela situação não fosse só dele” (E9) 
Um segundo grupo foi formado em 2007 e teve como produto final do grupo um reflexão coletiva sobre limites e possibilidades.

\begin{abstract}
"Inicialmente o grupo queria fazer um mega evento, um mega congresso nacional para discutir violência e acesso à justiça, e o que foi trabalhado principalmente com o grupo foi a possibilidade de limite, porque isso é muito comum na vítima do CRAVI também, ou ela faz justiça a qualquer custo e a lei não importa porque naquele momento de revolta chega a ver a lei como mediocre, de forma minimizante, então foi interessante esse trabalho com o grupo de 2007." (E9)
\end{abstract}

Em 2008 não houve a realização desse grupo em razão de insuficiência de encaminhamentos para participantes, pois as atividades do grupo de cidadania exigem que o usuário esteja minimamente fortalecido, além do interesse na temática de discussão.

Vale ressaltar que nem todos os entrevistados realizam o trabalho de acolhimento e atendimento às vítimas de violência, alguns atuam mais na articulação de $\operatorname{rede}^{153}$, na coordenação e orientação política dos casos. Mas todos os técnicos, com exceção dos defensores, participam de reuniões semanais de discussão de casos e reunião de equipe ${ }^{154}$, independentemente se trabalha ou não no atendimento direto às vítimas. No caso dos defensores, em razão do modelo de parceria, a participação nessas reuniões é mensal ${ }^{155}$, e não semanal.

As principais demandas ${ }^{156}$ levadas ao CRAVI se referem principalmente a questões jurídicas e psicológicas; para o serviço social raramente há uma demanda delineada e clara desde o acolhimento. São pedidos de ajuda para construir um caminho possível, numa "busca de algum tipo de possibilitação de uma felicidade após o horror".

\footnotetext{
${ }^{153}$ Há uma equipe de rede entre os técnicos do Cravi, a fim de fortalecer os contatos e parcerias institucionais. Essa equipe é formada por uma psicóloga, uma assistente social, assessor jurídico e coordenadora. As atividades principais dessa equipe de rede eram: divulgação do Cravi, sistematização de um banco de dados com as instituições da rede de serviços, participação em eventos e contato cotidiano para troca de saberes, além de observar e sensibilizar outras instituições para que não ocorram revitimizações.

${ }^{154} \mathrm{Em} 2004$, além da reunião de equipe, havia também outros espaços para distanciamento, reflexão e discussão do caso, fundamental para a qualidade do serviço prestado: a supervisão clínica (para os psicólogos e para as assistentes sociais; o núcleo jurídico não tinha supervisão) e a supervisão institucional - que era realizada com a equipe toda, inclusive com os coordenadores e com os profissionais do administrativo, para análise, discussão e supervisão de casos e de questões institucionais que atravessavam o serviço prestado.

${ }^{155}$ Embora seja prevista uma participação mensal dos defensores públicos nas reuniões de equipe, de acordo com as entrevistas essa participação ocorreu em apenas uma reunião durante os seis meses de contrato da equipe de defensores que atuava no momento da realização da pesquisa de campo.

${ }^{156}$ As demandas mencionadas pelos entrevistados baseiam-se, primordialmente, aos casos relacionados à violência fatal - tradicionalmente atendido no Cravi. As demandas relativas aos casos de violência doméstica e sexual praticamente não foram mencionadas nas entrevistas - provavelmente pelo fato de que tais questões tenham sido atendidas na instituição há pouco mais de um ano desde o momento das entrevistas e não tenham sido ainda incorporadas no discurso da equipe.
} 
A busca por justiça é uma das principais demandas levadas ao centro, mas essa justiça muitas vezes se confunde com um sentimento de vingança e raramente é identificada com o sistema de justiça formal. A demanda jurídica se traduz em pedidos de acompanhamento processual e informações sobre o processo criminal. Em alguns casos, os usuários acham que há a necessidade de nomeação de um advogado para que investigação criminal tenha prosseguimento ou para defender os familiares da vítima de violência fatal. A vitimização secundária também é relatada e as vítimas solicitam a presença de um advogado para "garantir" melhor tratamento nas instituições de justiça e segurança. Embora a maioria das questões seja relacionada ao procedimento criminal, outras demandas jurídicas como assistência para interposição de ações de natureza cível ou de família e sucessões também foram mencionadas nas entrevistas - como ações de inventário, pedidos de indenização, alvará, dentre outros.

Quanto às demandas psicológicas, a queixa majoritária é em relação às questões em torno da elaboração do luto, da dificuldade de conviver com a perda provocada pela morte violenta e questões de cunho depressivo: "quero um psicólogo para mim, para meu filho, porque sofri muito mesmo depois disso que aconteceu", ou porque a cena da violência não sai da cabeça e fica se repetindo, ou pela perda das referências da vida. São, em geral, pedidos de construção de um sentido, de superação de impotência diante da violência. Há casos de pessoas que perderam seus familiares há mais de 10 anos e procuram o CRAVI para apoio psicológico.

A demanda social raramente é clara, fazendo-se necessário conversar e estimular a reflexão sobre como está a vida da vítima, quais as dificuldades (seja financeira, de transporte, de trabalho ou renda etc) até que a demanda social seja delineada. Quando há algum pedido em relação ao serviço social, geralmente não se refere à proposta de atendimento da instituição, como pedido de cesta básica ou benefícios - nesse caso, é feito encaminhamento para a subprefeitura do local de moradia do usuário ou outro serviço da rede.

\footnotetext{
“As questões que o usuário traz relacionado ao papel social dele na sociedade, as dificuldades que ele vem encontrando, eles trazem muito a questão do trabalho, informação, de pertinência dos locais que eles vão buscar auxílio, às vezes isso chega muito misturado." (E10)

"Pro serviço social, a gente vai construindo uma demanda, não chega uma demanda pronta, mas uma coisa também que o serviço social tem investido bastante em trabalhar com essas pessoas é dessas pessoas poderem circular nesse social de uma forma mais pertinente, então o que isso significa, por exemplo, no caso de violência doméstica ou violência sexual muitas instituições estão envolvidas e estas instituições pouco conversam ou quase nunca conversam (...) a pessoa fica toda desmembrada, em cada instituição ela tem que
} 
falar uma coisa como se ela fosse completamente dividida e fragmentada, então um trabalho que a gente tem oferecido é justamente a partir do lugar social poder fazer uma reflexão com a pessoa: "Nessa instituição que você vai, qual é a função dessa instituição? Por que essa instituição existe? O que você vai fazer lá? Que reposta essa instituição pode te dar e que resposta ela não pode?" Porque às vezes essa pessoa vai correndo de instituição em instituição esperando uma resposta que não tem, não é lá, eu costumo dar um exemplo que é pedir pão no açougue, não tem, não vai ter pão no açougue, você vai sair sem nada." (E14)

Um histórico de violência às vezes é levado como uma demanda para que esse ciclo seja interrompido; mas em outras ocasiões é necessário mapear conjuntamente ao usuário situações de violência que foram se repetindo para que esse ciclo seja percebido e possivelmente rompido.

A maioria das fontes de encaminhamento para atendimento no CRAVI é do sistema de justiça - são alguns promotores, alguns delegados, o Departamento de Homicídios e Proteção à Pessoa (DHPP), algumas varas judiciais e o Instituto Médico Legal (IML). Algumas instituições que atendem outros tipos de violências também encaminham vítimas ao CRAVI. Alguns ex-usuários indicam o serviço a familiares, vizinhos e colegas; e há poucos usuários que tomam conhecimento sobre a instituição via internet ou pela lista telefônica.

Vale ressaltar que os encaminhamentos são feitos para atendimento no CRAVI, mas não são compulsórios. Durante o acolhimento, os técnicos informam a pessoa sobre o trabalho desenvolvido na instituição, esclarecendo sobre o atendimento prestado às vítimas de violência, no contexto do acesso à Justiça diante da violação de direitos e da promoção dos direitos humanos. Nessa ocasião também é informado sobre a possibilidade de desligamento em caso de três faltas sem justificativas nos atendimentos marcados ${ }^{157}$.

A divulgação do serviço é feita por meio de distribuição de folders e cartazes afixados em locais do circuito da violência, como IML, delegacias e fóruns judiciais. A participação em eventos também favorece a divulgação do trabalho e consequentemente alguns encaminhamentos. Com a formação de uma equipe de rede, houve maior investimento na divulgação e parcerias, o que resultou no encaminhamento por fontes que antes desconheciam a instituição, como serviços de saúde e universidades.

Durante o acolhimento é questionado como a vítima soube do serviço e quem a indicou para o CRAVI. Quase todos os usuários foram encaminhados por alguma outra instituição, raramente há procura espontânea. No entanto, parece não haver clareza sobre

\footnotetext{
${ }^{157}$ Mesmo combinado durante o acolhimento, em caso de três faltas sem justificativas, é feito um contato com o usuário antes do desligamento.
} 
quais são as fontes encaminhadoras. São alguns promotores, alguns delegados, alguns defensores, algumas varas criminais e algumas instituições, mas essas fontes não são identificadas numa relação institucional de parceria, com uma troca efetiva sobre os casos, as demandas, o histórico da vítima, suas condições de vida, encaminhamentos futuros e possíveis resultados.

\section{4. acolhimento e trabalho interdisciplinar}

Atualmente o acolhimento é psicossocial. Até 2007, os profissionais da área jurídica também participavam desse processo; entretanto, com a saída dos advogados da instituição e com a parceria da SJDC e DPESP, a participação dos defensores no acolhimento se tornou inviável, seja pela enorme demanda de trabalho, seja pelo modelo de contrato de parceria firmado entre as instituições. ${ }^{158}$

O contrato firmado entre SJDC e DPESP, de novembro de 2007 a outubro de 2008, previa a participação de quatro defensores públicos, em regime de plantão quinzenal, no período das $9 \mathrm{~h}$ às $12 \mathrm{~h}$, às terças e quintas, durante seis meses. A partir de novembro de 2008, a parceria passou a incluir o total de seis defensores, em regime de plantão semanal, durante um ano. Com esse novo formato, havia a expectativa de que os defensores passassem a participar também dos acolhimentos, entretanto, como o período de pesquisa de campo foi encerrado no final de novembro, não houve tempo hábil para verificar como isso foi concretizado no cotidiano da instituição.

A maior participação dos defensores públicos nas atividades do CRAVI, seja no acolhimento, seja nos atendimentos, seja nas reuniões de discussão de casos, foi comentada por todos os entrevistados, inclusive pelos profissionais da área jurídica. Um defensor público foi categórico ao afirmar que a presença constante do defensor na instituição favoreceria maior troca e discussão de casos, para efetiva integração e atendimento interdisciplinar.

\footnotetext{
"Eu acho que até a intenção do CRAVI é esse maior contato entre os técnicos mesmo, mas em virtude da atuação da Defensoria nesse esquema de plantão de quinze em quinze dias, hoje essa atuação é mais isolada, embora não totalmente, tem esses encontros de quarta-feira que a gente discute os casos mesmo, os aspectos jurídicos e não jurídicos, mas no geral, na grande maioria, cada um trabalha a sua atribuição, os psicólogos a parte psicológica e os defensores com a parte jurídica, mas a intenção do CRAVI é essa, é haver um trabalho conjunto, mas às vezes isso não é possível até por essa restrição da Defensoria, só terça e quinta, de quinze em quinze dias, então é complicado ter uma interação maior, embora seja essa a idéia, o ideal é esse." (AJ2)
}

\footnotetext{
${ }^{158}$ Para maiores informações sobre a atuação da Defensoria Pública do Estado de São Paulo no Cravi, veja o item 6 sobre "o papel do direito no atendimento às vítimas de violência".
} 
É interessante notar que em diversos momentos, ainda que o entrevistado não participasse do atendimento direto, havia um conhecimento mínimo sobre os procedimentos e a atuação das diferentes áreas - foram comuns expressões como "pelo que os técnicos comentam nas reuniões", ou "pelo que ouço dos técnicos".

Todos os entrevistados comentaram sobre o acolhimento e atendimento com conhecimento básico sobre cada área, com exceção dos profissionais da área jurídica, que relataram basicamente sobre o atendimento jurídico prestado. Cumpre ressaltar que o assessor jurídico - que atua integralmente no CRAVI, participando das atividades e reuniões semanais - tratou sobre questões das outras áreas e sobre o processo de acolhimento na instituição. Por outro lado, no discurso do defensor público não há clareza sobre os procedimentos envolvidos no acolhimento e "basicamente tudo se inicia no psicológico", não há referência ao serviço social e a integração parece mínima, vez que as demandas e os atendimentos relatados são basicamente jurídicos.

Existe uma demanda recorrente em praticamente todas as entrevistas por uma supervisão institucional ${ }^{159}$ e maior integração entre os defensores públicos e os técnicos do serviço social e psicologia.

\begin{abstract}
"sobre a construção do saber interdisciplinar, temos reuniões e (...) a vivência desse transpor de saberes na prática cotidiana você ficar pensando e repensando isso, em reuniões também esse saber é conversado e também temos agora a produção de texto sobre isso, isso é uma coisa. O cuidado com o profissional que é interessante que tínhamos a supervisão institucional e hoje não temos, está previsto ter, mas no momento estamos sem supervisão institucional que é um cuidado que não está acontecendo. Outro cuidado é a discussão constante nas reuniões de quarta-feira que os técnicos sentam para conversar, para rever a prática" (E13)
\end{abstract}

"Nós estamos nos preocupando bastante com isso ultimamente. No início do ano nós estávamos aguardando supervisão, na medida em que o tempo foi passando nós fomos vendo que não dá para esperar, não dá para ficar todo dia dentro do CRAVI com as demandas que os técnicos têm contato diariamente e não ter uma supervisão para trabalhar essas questões, não sair, não ver outras coisas. O que nós temos feito é intensificado o trabalho de rede visitando outras instituições, participando de seminários, de cursos, de palestras, não é o ideal. Eu não digo que essa participação não seja o ideal, a participação sim, só essa participação não, mas foi uma forma de respirar fora do CRAVI, não dá para ficar só aqui dentro porque o trabalho acaba ficando alienante." (E9)

"A gente faz atendimento juntos e acolhimento principalmente juntos, reuniões, tirando o pessoal da defensoria, que participa de uma reunião por mês. Com eles, eu quase não encontro, eu quase não converso, (...) então eu só encontro com o pessoal da Defensoria nessa uma vez por mês, é uma porcaria, não tem relação, tem alguma relação, essa, muito ruim, que eu não vejo, quase não sei quem é, que trabalho que está fazendo, tem que se comunicar através de um

\footnotetext{
${ }^{159} \mathrm{Na}$ ocasião das entrevistas, a equipe estava há um ano sem supervisão clínica e institucional, em razão de impossibilidade de contratação de supervisor diretamente pela SJDC. Anteriormente, a contratação de supervisores clínicos e instituicional era realizada por meio de convênio entre SJDC e um ONG.
} 
livro de recados (...) Com os outros técnicos é muito mais próxima a relação." (E14)

"O papel deles [dos defensores públicos] é de promoção dos direitos humanos, acesso à justiça, orientação, ajuda mesmo em alguns casos a conseguir algumas coisas em relação ao sistema judiciário, o papel é esse, é isso que se espera, mas para isso operar direito dentro do CRAVI, eu entendo que precisa ter presença, a pessoa precisa estar no CRAVI (...) três horas não dá tempo. Não dá, tem toda a esfera da realidade, não dá para fazer um debate com quem não está presente." (E11)

"São muitos telefonemas, às vezes a gente até enche um pouco a paciência dos defensores e infelizmente a gente tem que dar conta de algumas coisas que a gente esperava ser papel da Defensoria e veio pro resto da equipe, e de vez em quando tem que encaminhar o caso para uma outra instituição que tenha condições de fazer o serviço do CRAVI, que nós, por conta desse contrato que não está bem armado, ficamos impossibilitados de prestar um serviço decente", (E11)

A troca entre os profissionais é apontada como relevante para a vítima em atendimento:

\begin{abstract}
"se não tem uma discussão cada um pode dar uma direção que pode até ser oposta, se há uma conversa com uma direção comum do caso mesmo que seja por vias diferentes, isso faz muito efeito, faz muita diferença no atendimento. Não que se faltou o diálogo vai dar alguma coisa errada, não dá para garantir isso, mas no caso em que tem mais diálogo entre as áreas a gente vê que não garante, mas a chance de ter um atendimento de melhor qualidade, a chance é bem maior." (E12)

"é muito [relevante para a vítima a existência de um dialogo entre os técnicos] porque o ser humano tem vários aspectos, ele tem demandas em várias áreas diferentes. Eu fico me perguntando, numa instituição onde as áreas não se conversam, já pensou se o usuário tivesse que a cada atendimento em cada área recontar toda história dele e reviver todo aquele sofrimento, claro que em cada área ele vai recontar essa história, mas ele vai recontar de uma forma específica, direcionada à área, o técnico vai trabalhando nesse sentido com o usuário, mas a possibilidade de construção de um projeto institucional de atendimento eu acho que dá uma certa qualidade para o atendimento. " (E9)
\end{abstract}

A integração entre os técnicos das diferentes áreas parece ser estimulada pela própria instituição. Há espaços de troca de saberes e discussão de casos em reuniões semanais da equipe e reuniões das áreas de atendimento, além de um investimento na sistematização da metodologia de acolhimento e atendimento de cada uma das áreas - o que tem favorecido o diálogo e apropriação do trabalho das áreas pela equipe toda.

Mas essa integração precisa ser construída e investida. Nem todos os técnicos participam de atendimentos interdisciplinares; parece haver a necessidade de uma primeira apropriação da área do técnico para depois participar de um atendimento interdisciplinar. As discussões de caso e as reuniões em equipe favorecem essa troca.

"Não adianta querer só ficar sabendo o que o serviço social faz, tem que sentar, discutir um caso e ver, acontece assim por causa daquilo, o que você está fazendo que pode ajudar, o que estou fazendo aqui que pode te ajudar. Agora a gente está pegando também aquela coisa da avaliação socioeconômica, o que a avaliação socioeconômica diz pro seu trabalho, o que você pode utilizar disso 
no trabalho, mas a relação é uma construção às vezes mais lenta, às vezes mais rápida, para mim depende sempre do momento em que a gente está, momento da gestão daqui. Nesse sentido que a gente estava falando de você atender o sujeito, que você não fragmente, que você possa compreendê-lo em várias dimensões que ele carrega, isso ajuda demais porque (...) não adianta, por exemplo, eu assistente social chegar para a pessoa e falar em autonomia e emancipação e você psicólogo ir lá e passar a mão na cabeça, tutelar e não sei o que, e às vezes numa intervenção sua você está fazendo isso e não está se dando conta, e eu vou poder te apontar que não dá para ir por esse lado porque senão atrapalha meu trabalho aqui, então vamos construir um caminho que nos norteie e dá para construir isso, porque se a gente for atendendo a mesma pessoa, uma pessoa só, uma pessoa com todas as contradições, com todas as possibilidades, tem como você traçar um norte comum pros dois e cada um vai depois na sua, cada um vai com sua escuta, com seu conhecimento e vai aplicar aquilo, mas se você não tiver o mesmo norte você vai deixar a pessoa louca." (E14)

"Eu acho que o trabalho inter ele não precisa ser no mesmo espaço físico necessariamente, mas ele se dá também em reuniões, em conversas sobre o caso, em estudos quando você vai escrever sobre um caso." (E14)

"Nessa troca dos casos e encaminhamentos todo o grupo vai se apoderando de outras informações que faz com que cada um quando estiver no seu atendimento separado, ou jurídico, ou social, ou psicológico, tenha minimamente informações que ele vislumbre que há necessidade de encaminhar para outra área" (AJ1)

A interdisciplinaridade parece ser construída cotidianamente na instituição. A definição da metodologia de trabalho de cada área também favorece essa integração e essa foi uma das apostas da coordenação.

“Em 2007 (...) nós fomos tentando identificar algumas coisas dentro do CRAVI para tentar direcionar o trabalho e uma das coisas que nós identificamos é que embora houvesse atendimento entre as áreas, na maior parte das vezes as áreas não sabiam, não tinha muita clareza do que era função e tinha muita discussão de: "Isso é trabalho do serviço social." "Isso que você está fazendo é da psicologia." Então nós achamos por bem que as áreas pudessem sentar e escrever a sua metodologia de atendimento; não é criar uma nova metodologia, porque se o CRAVI existe há dez anos têm um jeito de trabalhar, que foi sofrendo modificações claro, aprimoramento, mas minimamente tem uma forma daquela área trabalhar aqui no CRAVI. Então a proposta foi que eles pudessem colocar no papel isso, que é uma forma também de repensar a sua atuação, rever suas bases teóricas metodológicas e a partir dessas metodologias por área, rediscutir o atendimento interdisciplinar, então continuam sendo feitos atendimentos em parceria, continuam discutindo os casos, mas eu acredito que essa construção, que ainda está em desenvolvimento, é um processo, essa construção tem ajudado bastante os técnicos nessa construção da interdisciplinaridade. Eu não diria que tem uma interdisciplinaridade constituída aqui dentro." (E9)

"Quando a gente começou a fazer as metodologias de áreas, (...) isso foi uma coisa que ajudou bastante, ajudou a fortalecer o grupo do serviço social que não era um grupo, eram duas assistentes sociais trabalhando cada uma no seu mundo e com suas experiências. Hoje o serviço social é um grupo que está tentando falar a mesma lingua, porque está tentando, porque a nossa formação é a mesma, mas a gente tem experiências profissionais muito diferentes." (E14)

"mesmo o atendimento psicológico é atravessado pela questão da cidadania e do acesso à justiça. Então o atendimento psicológico tem que estar condizente com essa diretriz institucional senão não dá para aceitar esse usuário no atendimento." (E12) 


\begin{abstract}
"O que prevalece tanto no acolhimento como no atendimento é a minha escuta que tem a ver com a minha formação, uma escuta com uma assistente social que vai olhar para esse sujeito, esse sujeito inserido numa sociedade, em relações sociais e olhar para esse sujeito como um ser social significa considerar esse sujeito numa historicidade, esse sujeito faz parte de uma história, ele constrói a sua história, ele está dentro de uma determinada sociedade, de uma determinada cidade que funciona de tal maneira que tem seus valores que tem suas regras, que tem suas leis. Olhar esse sujeito na sua historicidade não significa abrir mão ou desconsiderar que ele tem uma subjetividade e que ele está inscrito por leis, normas, o que significa também que é considerá-lo uma perspectiva que eu diria mais do direito, porque o direito olharia para esse sujeito." (E14)

"teve um investimento muito grande na missão institucional e na instituição mesmo. A gente deixou um pouco de lado outras discussões importantes porque a gente fez uma escolha no começo do ano, por exemplo, fazer um planejamento estratégico, pensar em ações, fortalecer os espaços coletivos de discussão, então fecha o CRAVI um dia todo e a equipe fica o dia inteiro junto, para pensar na instituição, e acho que isso ajudou bastante, apesar de toda essas perdas que a gente teve, foi possivel." (E12)
\end{abstract}

O atendimento é considerado interdisciplinar para a maioria dos técnicos entrevistados, mas em relação à participação da Defensoria Pública, o atendimento é visto como multidisciplinar. A interdisciplinaridade é reconhecida como meta ou ideal da instituição, embora não observada como prática entre todos os técnicos ${ }^{160}$.

\begin{abstract}
"Acho que agora é inter e multi. Não acho que dá para dizer que com a defensoria seja inter. Eu acho que ainda é uma diretriz o atendimento inter, acho que às vezes trans, mas hoje em dia tem muito essa divisão, não dá para dizer que a gente faz um trabalho inter com o direito no CRAVI, já fez. Mesmo com psicólogo e assistente social entra fazendo atendimento junto é muito pontual atualmente, às vezes acontece num caso mais difícil com advogado. Acho que com psicólogo e assistente social tem uma troca” (E12)

"Eu não consigo enxergar uma transdisciplinaridade ainda, eu acho que na psicologia e serviço social já dá para sentir uma interdisciplinaridade, mas as outras áreas e o jurídico têm uma atuação que ainda é multidisciplinar, no caso do atendimento" (E13)

"Eu acho que a gente está mais próximo do inter, em outros tempos a gente estava mais próximo do multi (...) cada um ali fechadinho e às vezes conversava alguma coisa. Acho que hoje a gente está no inter mesmo, mas muito distante de ser trans, muito, anos-luz." (E14)
\end{abstract}

\title{
4.5. dificuldades
}

A equipe entrevistada apontou uma série de dificuldades que se relacionam a quatro temas principais: a) condição e estrutura de trabalho (que inclui questão da remuneração, financiamento da instituição, continuidade do trabalho, formação da equipe, modelo de atendimento com a Defensoria Pública e supervisão); b) tema do trabalho e suas

\footnotetext{
160 Para alguns técnicos, há atendimentos multidisciplinares, interdisciplinares, transdisciplinares e unidisciplinares, conforme o caso e tipo de intervenção necessária naquele momento. Mas consideramos que se o atendimento for interdisciplinar como uma meta, uma intervenção multi ou unidisciplinar será precedida de uma conversa entre os técnicos envolvidos para sua definição como uma estratégia de atuação para o caso concreto.
} 
implicações - violência e vítima: impotência diante da gravidade das situações, condições socioeconômica e familiar, casos de violência estatal, observação de resultados e "evaporação" dos casos; c) relação do CRAVI com outros serviços e o contexto social: a formação da rede de atendimento, relação com parceiros, morosidade do sistema de justiça formal, efetivação dos direitos humanos; d) estrutura institucional do CRAVI (em relação à gestão e autonomia da instituição, relação com SJDC, compromisso político e compromisso com o serviço de atendimento).

Em relação à condição e estrutura de trabalho, a dificuldade principal se relaciona com a falta de supervisão institucional e com o formato da parceria com a Defensoria Pública para os atendimentos jurídicos.

\begin{abstract}
"Ter uma equipe, recursos humanos suficientes para desenvolver um bom trabalho. Superar essa dificuldade, essa dicotomia que se fez com a entrada da Defensoria, superar essas limitações, encontrar um caminho que eu ainda não sei qual é, a gente está sempre propondo algumas coisas, já melhorou do que foi no começo, mas superar isso" (E9)

"o trabalho interdisciplinar é um desafio. A gente tem a dificuldade hoje que é da defensoria, que acho que está dividido, mas eu acho que é um desafio mesmo, para saber quais os limites de cada área, as bordas, é um desfio." (E12)

"a gente voltar a ter um trabalho mais próximo mesmo com o Direito porque eu acho que isso é fundamental para o CRAVI porque o Direito é um eixo importantíssimo, é um desafio de como fazer com isso, esse é um desafio bem atual" (E12)
\end{abstract}

Mesmo se tratando de um programa do governo, a descontinuidade de financiamento e linha de atuação prejudicam o trabalho. Em razão de mudanças na diretriz política do CRAVI, não foi firmado nenhum convênio com organização da sociedade civil para execução do programa ${ }^{161}$, a equipe passou a ser fixa composta por funcionários da

161 Anteriormente, com os convênios celebrados entre as diferentes instâncias do Estado e a sociedade civil
organizada, havia o risco e problema provocado pela interrupção do convênio, o que provocava a
fragmentação da equipe, com a saída de parte contratada pelo convênio, e o comprometimento do trabalho
realizado junto aos usuários. O financiamento seguia uma lógica e um tempo que nem sempre contribuía para
a necessária continuidade do serviço prestado. Os convênios celebrados terminavam e as renovações ou
aditamentos podiam demorar um período incerto, o que prejudicava a motivação e estabilidade da equipe de
atendimento e também o andamento de alguns casos atendidos. Ainda que celebrados e formalmente
assinados, os convênios se viabilizavam apenas quando o financiamento era concretizado com o depósito dos
valores. Essa repetição representava uma das maiores dificuldades do trabalho. Havia um ciclo que dependia
da assinatura do convênio entre Governo Federal e Governo Estadual; assinatura de convênio entre Governo
Estadual e a sociedade civil organizada (por meio das Organizações não-governamentais); a dotação dos
recursos no orçamento; o depósito dos valores orçados nos convênios do âmbito federal ao estadual; e depois
o depósito dos valores referentes ao convênio com a ONG; a contratação dos profissionais e a retomada dos
atendimentos; o acolhimento de novos casos; a elaboração das propostas de atendimento levando-se em conta
o período do convênio celebrado; o oferecimento do serviço proposto. Logo começava novamente o ciclo:
novos convênios e a velha interrupção; o plano de trabalho para o próximo período de convênio, a preparação
nos atendimentos para a interrupção dos trabalhos, a pausa e a sua retomada após as assinaturas e ao depósito
dos valores, sem prazo determinado. Esse modo de funcionamento da instituição, que se operava por meio de
convênios com a sociedade civil, gerava uma profunda instabilidade e comprometia o serviço prestado e os
atendimentos realizados. Essa situação - comum em projetos sociais e comum aos demais centros de 
SJDC, mas outras dificuldades foram enfrentadas, como a contratação de supervisão institucional.

\begin{abstract}
"até o ano passado a gente tinha uma entidade que administrava todo o dinheiro que vinha tanto do governo federal quanto do governo estadual, e essa ONG estava aqui para contratar profissionais pros atendimentos, contratar supervisores, então ela tinha uma liberdade maior para fazer essas contratações, (...) ela não precisava passar pelo crivo do jurídico da Secretaria, porque ela já tinha personalidade jurídica, já tinha condições de resolver essas demandas e a partir do momento em que essa entidade sai, foi um engano tanto do gabinete quanto da coordenação que a gente ia resolver todos os problemas do CRAVI, e não é verdade, não é verdade, porque começaram a surgir vários problemas, este ano nós não conseguimos contratar supervisão técnica, supervisão institucional, os técnicos daqui ficaram um ano inteiro sem supervisão, então é muito dificill, é muito complicado, e não é só isso, a gente tem uma estrutura razoável, mas muitas vezes falta, falta uma estrutura melhor de trabalho, eu avalio dessa forma, falta de equipamentos muitas vezes, então acho que isso vai dificultando também no dia-a-dia do profissional, então eu avalio que esse ano foi um desastre, foi uma coisa ruim" (E15)
\end{abstract}

A instituição passou a atender casos de violência doméstica e sexual desde 2007, mas os técnicos não tiveram nenhum tipo de capacitação sobre o tema e havia uma previsão de realização de uma oficina no final de 2008 para formação sobre os temas. A falta de suporte e cuidado com os técnicos que prestam o atendimento direto às vítimas também foi indicado como um obstáculo em relação às condições de trabalho.

\footnotetext{
“A gente se preocupa muito com os usuários, nós os técnicos, e acho que a gente precisa que tenha um olhar para a gente também. Os funcionários, os técnicos da instituição andam muito doentes, adoecem muito e eu não sei a que se está atribuído, mas eu acredito que seja por conta da temática que é difícil, então a gente precisa de um cuidado, não que isso não seja percebido, mas tem alguma coisa que dificulta que essas coisas funcionem efetivamente, e eu acho que a falta de dinheiro não é, é burocracia mesmo, dinheiro a gente sabe que tem (...) então acho que tem que ser olhado com mais cuidado, para poder garantir a qualidade do serviço porque a gente tem a nossa parte, a gente faz, todo mundo é comprometido, mas acho que precisa da contrapartida também.” (E10)

"é uma preocupação com o serviço em primeiro lugar, com as pessoas que trabalham nesse serviço, com a população que é atendida pelas pessoas que trabalham nesse serviço. O trabalho de ponta quem faz somos nós, se a gente não tem uma estrutura por trás da gente, a gente fica mesmo em frangalhos, a gente não sustenta lá com o cara, é muito difícil, você pode ser o melhor profissional do mundo. Eu acho que não tem que sustentar porque você pode sim escorregar na casca de banana por mais seguro que você esteja do que tem que fazer, por mais que você tente se descolar de tudo o que está acontecendo estruturalmente e institucionalmente no CRAVI, você pode ter certeza que você escorrega." (E14)
}

referência e apoio a vítimas do país - revela certa ambigüidade do Estado ao não viabilizar estrutura adequada ao serviço, sem vincular orçamento adequado ao programa por ele criado. Daí a necessidade de promover e concretizar políticas públicas, independentes das flutuações das políticas governamentais, como se espera de uma política de direitos humanos. 
Outra questão apontada pelos entrevistados se refere ao desafio de dialogar com as diferentes áreas num exercício cotidiano para formação e fortalecimento da equipe e de um trabalho coletivo. A instabilidade da equipe prejudica contornos interdisciplinares do trabalho, que depende de confiança mútua, intimidade e construção de um atendimento integrado.

\begin{abstract}
"O desafio do CRAVI é com todas as conturbações, isolar isso, também fazer um bom atendimento, também conseguir desenvolver essa missão institucional. $\dot{E}$ um desafio trabalhar as três áreas, juntas, não é fácil, mais fácil se fossem separadas" (AJI)

"Essa troca de equipe para mim dificulta muito por exemplo o trabalho interdisciplinar, cada vez que chega uma pessoa, duas ou três novas, é um pouco de alguma forma começar do zero, não que você não tenha um trabalho construido, mas vai começar do zero no sentido de que você tem que passar tudo para aquelas pessoas novas que chegam e essas pessoas normalmente não tem experiência com trabalho interdisciplinar quando chegam aqui (...) Quando você fala que faz um trabalho interdisciplinar, que faz atendimento psicossocial, as pessoas já ficam muito temerosas, eu acho isso uma dificuldade ficar trocando toda vez de equipe a cada, sei lá, dois anos, você não tem tempo de desenvolver uma metodologia, não tem tempo de desenvolver uma confiança entre as pessoas para que esse trabalho se desenvolva bem, não tem tempo para criar uma intimidade no trabalho mesmo porque precisa ter uma intimidade no trabalho para conseguir fazer o trabalho desses, não é simplesmente uma coisa burocrática, vamos ler a metodologia de um trabalho interdisciplinar e vamos aplicar, a gente sabe bem disso." (E14)

"no trabalho eu acho que é o trabalho em equipe, porque pensar no CRAVI como instituição eu diria que é um pouco mais isso mesmo, de pensar no que a gente faz e como a gente transmite isso e o que a gente quer transmitir desse trabalho e como centro de referencia. Agora no trabalho do dia-a-dia, eu acho que é o trabalho, estar em equipe, principalmente pros psicólogos que estão acostumados a trabalhar mais sozinhos, mas como o tema é muito dificil, é muito fácil sobrar para a equipe ou passar para equipe algo desse horror mesmo que a gente escuta, mesmo para criar um voto de confiança para poder dividir, compartilhar o caso, eu acho que esse é um desafio grande pra gente." (E12)
\end{abstract}

Outras questões ligadas à estrutura de trabalho foram indicadas como dificuldades: a composição da equipe técnica do $\mathrm{CRAVI}^{162}$, os salários e a necessidade de descentralização dos atendimentos.

"Há entraves, vários, eu podia elencar vários, os cargos aqui serem em comissão acho que atrapalha, deveriam ser concursados porque você cria um vínculo melhor com a pessoa, muitos cargos em comissão deveriam ser de alguém mais ligado logo abaixo do Secretário porque quando o Secretário sai, os comissionados saem, aqui não, aqui tem gente que está há anos, essa influência política não passa aqui, então deveria ser concursados, ter condição de salário talvez melhor, não sei se daria para ter plano de carreira, outro

162 Até 2007, quando havia convênio com organização não governamental, uma parte da equipe era contratada pelo projeto e outra parte era da Secretaria. Em razão da descontinuidade do projeto e do financiamento, a partir de 2008, toda a equipe é composta por funcionários públicos da SJDC. Os funcionários do Cravi ocupam, em sua grande maioria, cargos comissionados da SJDC, mas exercem funções técnicas e não políticas. Alguns cargos são concursados, mas para os funcionários do setor administrativo e raramente aos técnicos que atendem diretamente a população. Não há quadro de funcionários que prestam concurso e são designados para exercício no Cravi. 
entrave, de ser descentralizado, por mais que tenham duas unidades, atender o Estado de São Paulo inteiro, isso ficou na promessa porque como eu tinha falado quem está na Zona Leste já é longe, o que dirá atender outras cidades." (AJ1)

"mas aí nós temos um dilema, como publicizar sem a capacidade do atendimento. Quando você pergunta quais são as principais dificuldades do CRAVI, são essas, a capacidade de recursos humanos para poder fazer esse atendimento. Concursos na Secretaria não tem, são cargos comissionados e os cargos comissionados são limitados, tem um número de cargos que você pode ter, então eu acho que é um enrosco político que precisa se resolver." (E9)

Também em relação à condição e estrutura de trabalho, para o defensor público que atua no CRAVI, as dificuldades se referem ao modelo de trabalho contratado, em que o defensor não se desvincula das atividades regulares da Defensoira e cumula, em regime de plantão, o trabalho jurídico do CRAVI - o que prejudica a busca de informações sobre procedimentos em fóruns distantes do local de trabalho e o acompanhamento de demandas encaminhadas para Defensoria Regional.

\begin{abstract}
"O que é difícil às vezes é obtermos os elementos necessários para dar as informações para a família, como eu disse os defensores que atuam lá não se desvinculam da sua atuação originária e às vezes a gente está acompanhando um homicídio de Guarulhos, por exemplo, então fica extremamente difícil se deslocar até o fórum de Guarulhos para ter acesso aos autos então a gente usa muito de oficios, a gente expede oficios para as delegacias solicitando cópias integrais do inquérito eles respondem e mandam, e também para os juizes, a gente solicita cópias dos autos e também tem esse retorno, mas demora então às vezes a gente fica meio preso para marcar o atendimento com usuário nesses casos em que a gente depende dessas cópias, então os processos em andamento em Guarulhos e também Santo Amaro que ficam um pouco longe da sede do CRAVI, a maior dificuldade seria essa porque a gente tem que aguardar o retorno do oficio com as cópias para a gente poder agendar o atendimento com a parte para fazer a leitura de peças e esse tipo de coisa." (AJ2)

"Também uma outra dificuldade, novamente em relação à questão do defensor ter uma atuação extraordinária em plantão, então às vezes a gente propõe uma medida, mais na parte civel, a gente propõe uma eventual demanda civel e não é a gente que acompanha, é distribuido para um fórum regional onde tem um defensor que acompanha, então o usuário retorna ao CRAVI e cobra da gente informações sobre aquele processo mas a gente não tem, e geralmente como, embora cível, seja ligada à área de família, nem através da internet a gente não tem porque é segredo de justiça, então a gente mesmo propôs mas precisa encaminhar a parte para o fórum para conversar com o defensor do caso porque a gente não tem acesso." (AJ2)
\end{abstract}

Quanto ao tema do trabalho e suas implicações, as dificuldades elencadas se referem principalmente à resistência das vítimas em aderir ao atendimento e à impotência diante da gravidade da situação e da ineficácia dos serviços.

\footnotetext{
"as pessoas vem procurar, mas quando começa a mexer com esse tema e começa a trazer à tona toda essa história, muitas vezes as pessoas também não agüentam, desistem, tem a dificuldade financeira, que é real, mas isso hoje a gente vem conseguindo resolver essa situação porque quando a pessoa está em atendimento, (...) ela já recebe um passe para voltar daqui a uma semana ou daqui a quinze dias, então muitas vezes tem um esvaziamento do atendimento é no sentido de não agüentar mexer com a situação (...) essa dificuldade da
} 
pessoa lidar com a situação em si e um problema social mesmo que é a falta de grana." (E15)

"Lidar com esse tema, lidar com essas limitações que a gente tem, com essa impotência que a gente sente diante de várias situações que a gente presencia, que a gente convive no dia-a-dia, chega mães aqui dentro que dizem assim "o assassino do meu filho passa na frente da minha casa e dá risada na minha cara, (...) a polícia não fez nada (...) o inquérito, não virou nem processo, nem foi investigada a morte do meu marido, porque eu já fui várias vezes lá e eles dão risada da minha cara" entendeu? Então você também avalia como um órgão, um projeto, um programa, que você vai conseguir fazer alguma coisa, e muitas vezes a gente também não consegue porque a gente também fica de mãos atadas, então isso é muito sofrido, além da gente trabalhar com um tema tão pesado, a gente também trabalha com essas limitações que angustiam demais, (..) então é muito difícil, não é fácil” (E15)

“às vezes a gente fica trabalhando esse usuário durante anos, trabalhando junto com ele e quando vem a sentença final todo mundo é absolvido. Nesse sentido a gente vai trabalhando com o usuário ao longo desse tempo o que é a Justiça, o que é a Lei, independente do desejo da pessoa só vai conseguir se provar aquilo que tem prova, aquilo que tem testemunha. Então às vezes pode ficar parecendo que é um trabalho de acalmar a vitima, de amenizar a revolta, de conformar, pode parecer. O CRAVI luta muito contra essa visão, não é a nossa proposta, mas não é tão fácil deixar claro que não é essa a proposta. A gente tem que estar sempre mostrando os limites da justiça, limites de atendimento, limites da pessoa, do profissional." (E9)

A desistência da vítima em relação ao atendimento foi também apontada como desafiador; mas não no sentido de evaporação ou falta de adesão ao trabalho proposto, mas de renúncia mesmo: não querer o atendimento e preferir "tocar a vida" com a dor, a perda e a impunidade.

"para mim o que mais é difícil, falando no particular do atendimento, é quando a gente coloca uma proposta de trabalho para essa pessoa que nos procura e essa pessoa desiste, desiste porque não consegue mais suportar a vida que está levando, vira para a gente e fala: "Deixa, eu vou seguir minha vida do jeito que está." Mas é um seguir a vida muito mal, muito deprimido, muito revoltado, muito desesperançado (...) Acho que o mais dificil nesse particular do atendimento é isso, é saber que a pessoa desistiu de viver, desistiu de lutar por alguma coisa que fosse para a sua vida, desistiu, isso é o mais difícil" (E14)

$\mathrm{O}$ atendimento às vítimas de violência é um trabalho difícil. Não apenas pelas limitações da equipe e resistência da vítima ao atendimento, mas a intervenção em si é um desafio e os resultados do trabalho não são visíveis constantemente. O trabalho em si é um desafio cotidiano.

\footnotetext{
"Acho que o desafio maior é conseguir, que é uma coisa difícil, que esse usuário saia da instituição fortalecido de acordo com a proposta da instituição mesmo, da missão do CRAVI, que ele saia como um sujeito de direitos, que ele minimamente consiga exercer, ou plenamente, a sua cidadania, acho que é um grande desafio" (E10)

"é muito dificil ter essas informações e primeiro não se chocar e depois tentar vislumbrar soluções, porque essa palavra solução ou saídas conforme você ouve sobre o episódio violento, sobre a própria vida da pessoa, parece ser uma coisa impossivel no primeiro momento, no entanto o trabalho de alguns dispositivos aqui do CRAVI realmente funciona, não que a pessoa vai deixar de conviver com aquilo, deixar talvez de esquecer ou ter a lembrança daquele episódio, mas
} 
a pessoa que não estava tendo uma vida passa a ter uma vida com outro sentido, ela consegue com o atendimento aqui passando pelo atendimento social $e$ psicológico, talvez nem tanto pelo jurídico, mas de voltar a viver" (AJ1)

"Existem outras dificuldades, por exemplo, eu não sei se é uma dificuldade, acho que a gente é convidada para uma posição ética para repensar nossa prática cotidianamente. (...) um desafio é sempre estar se revendo, revendo a prática, sempre estar buscando referências éticas para poder se sustentar dentro de uma prática, poder se cuidar, dispor de recursos para se cuidar cotidianamente, eu acho que é desafio, não acho que é dificuldade, é desafiador você se rever cotidianamente na sua prática, acho bom.” (E13)

“Acho que o principal desafio é exatamente conseguir suprir essa falta de informação que as famílias sentem, de poder meio que traduzir os termos técnicos, explicar porque às vezes o inquérito é arquivado por falta de provas, é até uma conseqüência, como os casos são de crimes violentos, as pessoas tem receio de depor, ninguém quer se comprometer e meio que acaba como se a polícia, não faz parte da justiça, mas que a polícia fica num beco sem saída, ninguém quer falar, não tem muito o que fazer, se não tem provas acaba arquivando, e às vezes é dificil explicar isso para a família, geralmente eles já foram vitimas mesmo e estão dispostos a depor, mas outras pessoas que porventura tenham presenciado o crime, como às vezes também envolve policiais ou pessoas envolvidas com tráfico, é muito difícil conseguir provas concretas e tem uma dificuldade de explicar isso para a família também e soa como se fosse impunidade e quando às vezes não é, é a própria ineficiência do Estado." (AJ2)

Outra dificuldade indicada pela equipe entrevistada relaciona-se aos casos que envolvem violência praticada por agente público. Embora seja uma questão inerente ao trabalho realizado no CRAVI, a violência estatal é considerada uma "saia justa".

"Infelizmente nós vivemos em um centro urbano extremamente violento aonde na minha avaliação as políticas públicas ainda são escassas, frágeis e isso influencia muito na violência. Grande parte, eu diria que aproximadamente $30 \%$ das vítimas do CRAVI são vítimas de ação estatal e me parece que isso dificulta um pouco o trabalho porque somos do Estado e no caso o algoz é o Estado. Então eu acho que tem duas dificuldades, uma para o usuário, como eu vou receber apoio de quem de certa forma é o algoz, então tem uma dificuldade de trabalhar com o usuário essa questão. Outra dificuldade é trabalhar a justiça com um parceiro porque a Secretaria da Justiça e a Secretaria de Segurança Pública são secretarias parceiras. Trabalhar os casos que envolvem violência estatal é delicado, pelo menos delicado." (E9)

"Uma dificuldade do trabalho é quando a violência é institucional dos casos em que envolve agentes do Estado, aí sim é uma dificuldade muito grande, primeiro lugar porque o CRAVI pertence à Secretaria da Justiça, eu pertenço ao Estado, e tem que desenvolver um trabalho de uma violencia praticada por agente do Estado, pela Secretaria de Segurança Pública, por exemplo, aí eu acredito que o CRAVI encontra obstáculos de como manusear esses casos, de quais outras organizações, para quem esse caso pode ser comentado, quem podem ser os parceiros para uma solução, então envolve-se Ouvidoria, envolve a própria Secretaria de Segurança Pública, mas em alguns casos esse envolvimento não teve um fim desejável, porque os inquéritos na Justiça Militar, ou na Corregedoria da Polícia Civil, foram arquivados por falta de prova e isso acaba ocorrendo também absolvição ou impronúncia do réu no processo criminal e isso para o usuário, quando você traz essa informação para o usuário, que queria responsabilização, ele sabe que aquela pessoa praticou, é muito angustiante." (AJ1)

"é muito daquela cultura de que não vai dar em nada, eles são policiais mesmo e tudo conspira a favor deles (...) foi muito dificil explicar para a família que o 
fato dele ter sido posto em liberdade não era pelo fato dele ser policial, e sim por um problema no processo, estava demorando muito (...) e várias vezes eles me falavam que ele só estava sendo solto por ser policial, nesse caso em específico não era realidade, foi mais um aspecto processual mesmo, estava demorando muito para concluir a instrução e a prisão acabou sendo relaxada" (AJ2)

Essa dificuldade em relação aos casos que envolvem violência estatal, relaciona-se com as dificuldades agrupadas em seguida, quanto à relação do CRAVI com outros serviços e à sua própria estrutura institucional. A relação com secretarias parceiras parece ser ambígua entre o acordo político e o compromisso com a promoção de direitos humanos e encaminhamento de casos de violência fatal supostamente praticada por agente público. O acompanhamento dos autos de eventual processo disciplinar ou parcerias com organizações não governamentais no atendimento de casos dessa natureza também não parecem ser incentivadas ou adotadas pela instituição.

“O DHPP é Secretaria de Segurança Pública e é um dos principais parceiros do
CRAVI, parceiro com quem a gente pode contar, nós podemos encaminhar o
caso para lá e eles encaminham usuários para cá. São parceiros de confiança
da Secretaria. A dificuldade que eu digo é que alguns casos parece que a justiça
não anda, a possibilidade de esclarecer um caso quando tem envolvimento
policial é muito difícil, não se identifica: Era um policial, mas qual? Provar que
não foi em legítima defesa é muito difícil” (E9)
"A relação [com a Secretaria de Segurança Pública] é boa, mas esses casos têm
mais uma dificuldade, é boa, mas não é tão clara. É boa porque fazemos parte
do mesmo organograma da mesma instituição-estado, mas não é tão clara em
termos de cumplicidade, de solução para esses casos. Então recebem muito bem
as nossas informaçóes, os seus organismos, Corregedorias e Ouvidorias dentro
da polícia civil ou policia militar, realmente esses inquéritos e procedimentos
internos são abertos, mas geralmente findam em arquivamento" (AJl)

A relação do CRAVI com outros serviços e o contexto social também representam outras dificuldades ao trabalho desenvolvido na instituição. Os convênios com a sociedade civil para execução do serviço de atendimento e a articulação de rede foram problematizadas. 
fecha ou muda de endereço, essa rede acaba sendo circulante, então tem que ter esse trabalho constante" (E13)

Ainda que a relação com as organizações da sociedade civil e a formação de uma rede institucional tenham sido apontadas como dificuldades, o contexto social parece desafiar ainda mais a equipe, seja em relação ao acesso aos serviços e à cidade, seja quanto ao acesso à justiça, seja em relação ao exercício da cidadania ou à efetivação dos direitos humanos.

\begin{abstract}
"A Justiça precisa andar mais rápido, é uma coisa que não depende do CRAVI entendeu, não depende da gestão do CRAVI, mas é extremamente importante para que esse trabalho possa acontecer de forma eficaz" (E9)

“Tem um problema de São Paulo, que é o transporte, toda vez que chove quase todos os usuários faltam porque eles não conseguem chegar na hora e desistem no meio do caminho, é incrível, no dia que chove, ai começam as ligações. A pessoa que está vindo há um mês ou dois, ela nem vem mais, porque sabem que não conseguem chegar na Barra Funda, é triste esse problema de transporte público." (E11)

"existe uma dificuldade que é social, por exemplo, os territórios onde a violência acontece muito são um pouco distantes da Barra Funda, então tem uma dificuldade fisica desse usuário chegar até o CRAVI” (E13)
\end{abstract}

Questões amplas como a supremacia do interesse privado em detrimento de interesse público, formas de solução de conflitos, consolidação de relações democráticas e exercício da cidadania foram indicadas como dificuldades.

"O que eu vejo é uma sociedade civil hiper segmentada, às vezes segmentada individualmente, às vezes a pessoa não representa nenhuma corporação nenhum grupinho, é ela só, solta no mundo. E as pessoas lutam pelos objetivos dos seguimentos. O bem comum acho que já foi abolido, é difícil ouvir alguma coisa sobre bem comum ou ver alguém abrindo mão de uma satisfação em prol do bem comum ou da estruturação de algum direito ou alguma coisa que seja importante. O pessoal está muito segmentado na sociedade civil, não dialoga, numa posição de acusação só, de um segmento acusando o outro e ninguém se responsabiliza por nada que não seja do seu próprio interesse" (E11)

$\mathrm{O}$ dilema entre a necessidade de capilarizar o atendimento às vítimas, com ampliação e divulgação dos centros de atendimento, e a capacidade do serviço e da equipe também foi comentado pelos entrevistados. O investimento na prevenção da violência, a sensibilização dos atores institucionais para evitar a revitimização e o efetivo acesso à Justiça também foram mencionados como dificuldades.

\footnotetext{
“Aqui a demanda é infinita, o serviço é pequeninho." (E11)

"é um cuidado com o profissional que a gente reveja essa prática cotidianamente, mas, por exemplo, isso leva horas do técnico, então esse técnico não está o tempo todo só para atender (...) mas como a gente tem um quadro de funcionários do CRAVI que está restrito, ampliar o número de atendimentos talvez exigisse contratação de mais mão-de-obra e são coisas que muitas vezes o Estado não dispõe, não tem recursos ou muitas vezes não há vontade política." (E13)
} 
"existe um desafio macro que é poder também atuar numa linha de prevenção, atuar de uma forma política, acho que tem que ter mais vontade politica para que esse trabalho aconteça, é um trabalho que demanda várias coisas" (E13)

Desenvolver um trabalho baseado nos direitos humanos é um desafio.

"falar em direitos humanos hoje realmente é um desafio. O que eu digo aqui no CRAVI é que realmente eu acho que nós somos um dos lugares que nada muito contra a maré olhando que a maré é toda essa sociedade que também tem gente que se preocupa com direitos humanos porque a sociedade é isso várias contradições, várias diferenças, mas quando a gente trabalha aqui no CRAVI com grupos, por exemplo, é mais uma forma de nadar contra a maré porque cada um vai lidar com essa questão de violação de direitos de um jeito e a gente bota essas pessoas no grupo para conversar, para tentarem achar soluções conjuntas ou coletivas, olhar para o outro dentro do grupo. Então eu acho que é um desafio, para nós que trabalhamos com direitos humanos, tremendo, mas acredito que tem possibilidades quando eu vejo, que nós não existiríamos há dez anos apesar de muito frágeis, outras instituições existem para lutar e falar sobre isso. Tem possibilidades, tem gente também falando disso, tem gente fazendo barbáries, tem gente falando barbaridades, mas tem gente também falando sobre direitos humanos fazendo ações e tal. Acho que não dá para a gente reduzir tudo a nada de direitos humanos" (E14)

"a temática dos Direitos Humanos tinha que estar em todos os espaços, é um desafio a gente pode agregar todas essas instituições que trabalham nessa perspectiva e botar todo mundo para conversar porque eu acho que fica cada um no seu cantinho e ai no cotidiano quando você tem algum desafio, ou alguma não dá certo, você se sente o pior dos seres humanos, nadando contra a maré, se a gente pudesse ter um fórum permanente... Isso é um desafio muito grande; para o trabalho daqui, eu acho que tem a ver com isso de trazer os Direitos Humanos para as pautas porque eu acho que acontece uma conscientização em todos os niveis, estaduais, municipais, federais, de Secretaria, de coordenação, técnicos, eu acho que é isso, colocar isso em pauta e fazer barulho mesmo com isso, é a forma que eu acredito para o trabalho também, na desalienação, você falar sobre um tema, discutir sobre um tema, acho que isso vai mobilizando as pessoas" (E14)

A estrutura e autonomia do CRAVI sintetiza grande parte dessas dificuldades mencionadas pelos profissionais entrevistados. A fragilidade institucional representa um enorme obstáculo ao próprio atendimento oferecido. A relação do CRAVI com a Secretaria da Justiça e da Defesa da Cidadania também representa uma dificuldade na medida em que o poder público tem pouco conhecimento sobre a especificidade do programa que coordena e algumas questões políticas podem influenciar o encaminhamento de alguns casos (especialmente quando relacionados a violência estatal).

"um programa frágil como o CRAVI no sentido da sua estrutura e da sua fundação mesmo eu diria, ele só prejudica os atendimentos ali da ponta. (...) isso é uma fragilidade que eu não vejo muito como sair disso no cotidiano se a gente não tiver uma mudança mais estrutural, essa é uma dificuldade, das pessoas poderem olhar, das pessoas que eu digo é a Secretaria porque é quem tem poder de fazer alguma mudança aqui dentro no sentido de estrutura, enquanto as pessoas não olharem para cá e verem essa necessidade de ter uma equipe fixa que precisamos ter pessoas comprometidas com esse trabalho, que não é fácil, não é mais um trabalho, mas é um trabalho que demanda muito de pessoal, de emocional, de estrutura psicológica, física e tal. Enquanto as pessoas não tiverem preocupação com isso aqui no CRAVI eu vejo que essas dificuldades que 
a gente tem vão continuar por mais que a gente faça o movimento aqui dentro." (E14)

"É um centro referência que atende vitimas de violência fatal, lógico que ampliou o recorte, mas que atende vítimas de violência fatal, é uma instituição que denuncia também uma falha do Estado, tanto de oferecer segurança e proteção a população, como também recebe casos de abuso de poder, então acho que uma das dificuldades é uma vontade política para que esse centro possa ser ampliado, não sei se esse centro ou uma política pública, está em um nivel mais macro, e o que consigo enxergar é por esse viés que o CRAVI existe porque o Estado falha em muitos pontos." (E13)

Um programa governamental que denuncia a falha do próprio Estado tem suas ambigüidades. Ao mesmo tempo em que há um investimento para que o atendimento às vítimas de violência seja oferecido no Estado de São Paulo (o financiamento do CRAVI é integralmente público, entre verbas federais e estaduais), os recursos não são aplicados de forma a garantir a efetiva superação de ciclos de violência e promoção dos direitos das vítimas de violência. Alguns casos, especialmente aqueles que explicitam abuso de poder e violência estatal, são considerados "delicados" por envolver secretarias parceiras, a “direção política” pode prevalecer no encaminhamento de determinados casos.

Nesse contexto, o gestor do programa precisaria aliar características pessoais e profissionais para uma coordenação efetivamente comprometida com a tarefa do CRAVI. Além de conhecer as "burocracias administrativas" da Secretaria da Justiça, para saber "por onde caminhar em todas essas emboscadas da politica pública", é fundamental que se acredite no CRAVI, no sentido de ter compromisso com a finalidade do programa, com o serviço oferecido e com a população atendida, antes e acima de eventual compromisso político ou pessoal.

Assim, a competência e o compromisso são essenciais para a coordenação da instituição e representam, de certa forma, dificuldades. A coordenação desse programa não se mostra fácil, a relação a ser costurada entre o CRAVI e a própria SJDC é uma dificuldade apontada pelos entrevistados.

\begin{abstract}
"porque tem umas pessoas que não entendem, não conseguem, não querem entender o trabalho do CRAVI, que é diferente dos outros lugares, eles acham que o trabalho é igual ao trabalho no CIC e não é, eles acham que qualquer pessoa pode chegar e ser atendida por um psicólogo e depois vai embora, e não é assim, é um programa, tem todo um planejamento de trabalho, tem todo um dispositivo de atendimento, tem toda uma forma de trabalhar com foco na missão, então isso é muito difícil, as pessoas que trabalham (...) ali na Secretaria, é muito difícil (...) não é fácil não, a ponte da Secretaria com o CRAVI, (...) então é sempre uma luta, e isso vai desgastando, vai desgastando tanto a coordenação e vai desgastando também a equipe (...) é dificill." (E15)
\end{abstract}

O compromisso com o serviço oferecido e a responsabilidade diante de cada um das situações de violência atendidas no CRAVI devem ser coletivos, ou seja, da equipe 
inteira, não apenas da coordenação do programa. No final, parece ser a personalidade e a disponibilidade de cada profissional que faz a diferença em relação ao trabalho desenvolvido na instituição.

\begin{abstract}
"A gente tentou fazer um grupo de estudos juntos para estudarmos a temática que a gente está levantando aqui, mas esse espaço foi um pouco censurado, ele não vingou, "tempo demais, temos outras coisas para fazer", a supervisão não saiu, por conta da Secretaria. Quando a gente começou a fazer as metodologias das áreas (...) acho que se não fosse a disponibilidade pessoal isso não aconteceria porque não tem tempo para fazer, não tem espaço para fazer, nunca tem nada para fazer. Então vai ficando tudo muito relegado ao plano do pessoal, do particular, se você está a fim, se você consegue, se você pode, se você quer, não existe uma coisa do coletivo." (E14)
\end{abstract}

Embora a instituição seja pública, o compromisso e o interesse públicos às vezes podem ser sobrepostos por interesses de natureza política ou particular, o que certamente dificulta o trabalho desenvolvido.

\footnotetext{
"Às vezes eu sinto que isso aqui é um trem sem maquinista em todas as esferas que poderia ter de maquinista" (E14)
}

Por se tratar de uma instituição pública, a responsabilidade pelo serviço oferecido deve incluir necessariamente a finalidade do atendimento à população e a promoção dos direitos das vítimas. A complexidade é ainda maior por se tratar de uma organização pública, pois se faz necessário conjugar a finalidade pública de atendimento às vítimas de violência aos pactos e metas firmados politicamente no âmbito do governo federal e estadual. Outra dificuldade apontada é de se consolidar como política pública de atenção às vítimas de violência, adequada e eficaz.

\begin{abstract}
"parece que não tem um plano institucional, pela primeira vez no começo desse ano a gente fez o planejamento estratégico, a gente pensou agora vai, tem todo um plano que vamos seguir. Tudo bem tem umas metas que a gente tem que seguir, mas não foram metas que foram dadas no planejamento estratégico, foram metas que a gente se comprometeu com Brasília, com a Secretaria e que se não cumprir já sabe o que acontece, corta a verba e tchau e benção. Parece que é nesse sentido mesmo de fazermos um compromisso e a gente tem que cumprir porque senão a gente vai perder verba e o CRAVI pode fechar, mas não por coisa maior. Temos um compromisso com a população, temos um compromisso em divulgar o nosso trabalho porque achamos que nosso trabalho é importante, é de qualidade, ser centro de referência de fato" (E14)

"O CRAVI tem 10 anos, podemos dizer que está consolidado, mas é um desafio se tornar política pública por mais que ele tenha sido criado talvez como uma política pública, mas para ser política pública precisa de muitos aspectos a ser cumpridos, não só uma legislação que crie, não só um atendimento universal, mas que opere, que funcione mesmo. A assistência à saúde no Brasil é uma política pública, mas não funciona, então não é uma política pública, aqui da mesma forma" (AJ1)
\end{abstract}

Diante desse universo de dificuldades comentadas pelos entrevistados, um problema ainda maior a ser enfrentado parece ser a falta de respaldo da própria instituição 
para o êxito do encaminhamento das questões emergentes dos atendimentos às vítimas de violência, para promoção dos direitos humanos e rompimento de ciclos de violência.

\begin{abstract}
"Chega um momento em que só quem está de dentro que pode fazer alguma denúncia, só que você precisa se retirar para fazer isso, porque senão você vai ser retirado, estou esperando para ver onde a gente vai chegar, esse ano foi isso, eu estou esperando mesmo, então eu acho que em certo momento o que a gente aqui na ponta consegue fazer a gente faz, mas tem outros tantos mil exemplos em que a gente precisa sim da estrutura nos apoiando e que a gente não tem." (E14)
\end{abstract}

\title{
4.6. o papel do direito no atendimento às vítimas de violência - vítimas, direitos humanos e casos exemplares
}

A vítima, para os entrevistados do CRAVI, é um sujeito que sofreu uma violação de direito, dano ou lesão.

"Eu diria que 70\% da população brasileira é vítima. Vítima de uma situação opressora, vitima de uma desigualdade social, vítima da escassez de políticas públicas e de recursos, vítima da dificuldade de acesso a serviços e a justiça." (E9)

Em algumas entrevistas surgiu a noção de passividade da vítima; em outras o conceito da vítima direta e indireta ${ }^{163}$. Interessante notar que foi também destacado que a vítima é um "sujeito de direitos, deveres e desejos, não um objeto de prova"; também foi considerada vítima a pessoa que se sente vítima, "que acha que sofreu uma violação de direitos e que vive assim " 164 .

Embora o conceito de vítima esteja relativamente claro para os técnicos, as pessoas atendidas na instituição não se identificam, necessariamente, como vítimas.

\footnotetext{
“mas é uma excelente pergunta, é mais fácil definir o que é vitimologia, que é o estudo da vítima, mas o que é vítima é bem complicado e digo mais, tem muitas pessoas que são vítimas mas não se entendem como vítimas, aí é um outro trabalho que você tem que fazer porque a pessoa não se enxerga como vítima. Isso inclusive aqui no CRAVI quando a pessoa chega aqui, o usuário se torna usuário, há os não-casos e há os casos, mas quando é caso, pelo menos os técnicos, o CRAVI já está denominando-o de vítima porque aqui, pela missão institucional, é um centro de referência para ações e programas, políticas públicas que promovam o reconhecimento da vítima, acesso à justiça, cidadania, então aqui ela pode não chegar como vítima, mas para o CRAVI já é.” (AJ1)
}

\footnotetext{
${ }^{163}$ Ver capítulo 2 sobre vítimas de violência.

${ }^{164} \mathrm{Um}$ dos profissionais entrevistados destacou que considera como vítimas as pessoas "que acham que sofreram uma violação de direitos e que vivem assim, por exemplo, tem uma que diz de uma sociedade machista, que o pai dela era muito machista, isso é uma violação de direitos para ela, ela deixou de fazer um monte de coisas na vida dela por causa do pai. Isso não está na lei, que uma pessoa machista não está cometendo nenhum crime digamos assim, que está na letra da lei, no Código, ela não vai ser julgada porque ela é machista, por si só. Tudo o que eu estou falando que essa pessoa relatava porque ela se sentia vítima era assim: "Meu pai era machista então ele privilegiava o meu irmão mais velho e não a mim, e isso foi um sofrimento para mim" coisas desse tipo que não estão enquadradas na lei como um crime". (E6)

Interessante notar que essa abrangência do conceito inclui pessoas que sofreram violações de direitos, não necessariamente provocada por uma conduta considerada como crime.
} 


\begin{abstract}
"tem algumas pessoas que chegam muito nesse lugar de vítima: "Eu sofri, meu filho sofreu uma violência, morreu, estou muito mal", outras muito indignadas, revoltadas: "Eu sei que meu filho fez uma coisa errada, mas não precisava matar." Tem pouquíssimas pessoas que já chegam com um discurso assim: "Eu sofri uma violação de direitos", mas têm algumas que já chegam com esse discurso (...) não vem com um discurso de vingança já vem com uma outra forma de olhar para isso que aconteceu, tem muita raiva e muito revolta pelo que aconteceu, quer sim uma punição para a pessoa que realizou aquilo, mas é uma fala já de outro lugar. Tem outras pessoas que chegam aqui, isso mais em relação à violência doméstica e sexual, que nem falam que sofreram uma violação. Está mal, está deprimida, sabe que tem alguma coisa errada, mas não sabe nem dizer que aquilo que sofreu foi uma violação de direitos. É legal por um lado porque tem um trabalho e é por isso que a gente está aqui, para informar as pessoas para enfim, poder circunscrever isso também dentro de uma violação de direitos, mas isso particularmente me assusta um pouco porque a gente sabe há quanto tempo tem campanhas contra violência doméstica e sexual e quando eu vejo esses casos eu vejo quanto ainda falta de divulgação, o quanto ainda falta falar de direitos humanos e isso não é dito." (E14)
\end{abstract}

O desafio de lidar com a vítima de violência foi mencionado por todos os profissionais entrevistados, mesmo aqueles que não exercem atividades diretamente com as vítimas. Embora esse contato com as vítimas seja gratificante e enriquecedor, o horror da barbárie, a indignação diante dos fatos e a sensação de impotência exigem do profissional uma reflexão constante sobre a prática, demandam uma estrutura emocional para um distanciamento e elaboração dos fatos, evitando-se uma identificação prejudicial ao técnico e ao atendimento.

\footnotetext{
"mesmo que a gente não queira, mesmo que a gente ache que não vai ser atingido, a gente é atingido por essa questão da violência, porque a gente ouve, a gente participa da reunião de discussão de caso, então muitas vezes a gente fica indignado, eu fico muito indignada em alguns momentos pelo fato da questão da violência, do tamanho dessa violência, e muitas vezes essa violência ela veio do próprio Estado de direito, vamos pensar, então eu fico muito indignada com muitas coisas. (...) eu tento me preservar um pouco porque é muito difícil, não é fácil, não é fácil não, a pessoa tem que ter uma estrutura muito boa, tem que ter supervisão, tem que fazer uma terapia fora daqui, ela tem que ter um suporte (...) queira ou não queira, você vive, não vive da mesma forma que essa família, ou que essa pessoa está vivendo, mas você ouve, você avalia, você vê que realmente as coisas são muito complicadas, e muitas vezes é dificil, é dificil separar um pouco sabe?" (E15)

"se o técnico não tem um suporte importante, de terapia, de supervisão, ele não agüenta, não agüenta porque é muita violência, é muita queixa, é muita coisa e assim, muitas vezes nós como técnicos também ficamos assim, impotentes, diante do tamanho da violência e dificuldades de resolver muitas vezes essas questões das próprias instituições, do Judiciário, a gente também tem impotência total, a gente também fica angustiado de ver na televisão, na midia, nos jornais, que quem tem dinheiro não vai para cadeia, e quem não tem vai pra cadeia, e a violência muitas vezes acontece lá naquele lugar onde as pessoas são trabalhadoras e essas pessoas estão vivendo uma situação de violência iminente todos os dias, todas as horas, e nada é feito, então isso dá muita impotência pro técnico também, porque se o técnico tem dentro do seu estado de trabalho um suporte bacana, lá fora não existe esse suporte, porque muitas vezes as entidades não funcionam do jeito que a gente imagina que elas deveriam funcionar, então é muito difícil, não é fácil, a pessoa tem que ter muito claro o
} 
que ela vai fazer, que tipo de trabalho ela vai desenvolver, porque muitas vezes se você não tem esse suporte, você adoece, adoece mesmo." (E15)

"fica patente para mim agora na coordenação que muitas vezes a nossa equipe não tem um preparo para poder fazer esse trabalho de elaboração e não se identificar com o pessoal que está sendo atendido. Isso é uma coisa que a gente criou alguns dispositivos para tentar desenvolver a equipe nesse sentido, mas é um trabalho longo às vezes com algumas pessoas. Enquanto isso a pessoa está trabalhando e vai sofrendo todas as conseqüências, isso me incomoda bastante" (E11)

Por isso, o cuidado e o suporte para a equipe é fundamental. Esse apoio se traduz

em discussões de caso, supervisão institucional e outros cuidados individuais.

\begin{abstract}
"que pena que precisa existir o CRAVI por um lado, por outro lado a violência não vai acabar, a psicologia fala que a gente nunca viveria sem violência. Eu acho que por outro lado é bom que exista lugar como esse e outros lugares que possam atender as vítimas, acho que é um avanço. Como eu lido, eu acho tudo muito terrivel, tem umas coisa que a gente ouve aqui que nossa, a gente voltou para a época antes dos homens das cavernas, é a barbárie total e completa. (...) parece que quanto mais o homem avança em relação à tecnologia e tem cada vez mais riqueza, avança-se por um lado e por outro lado é a barbárie, é a miséria absoluta, é a podridão da humanidade. O que me ancora muito para eu poder trabalhar com essa temática é principalmente a teoria, mas ela não supre tudo, ela supre grande parte. As discussões em equipe me ajudam muito também, a gente está sem supervisão, mas a supervisão também era um espaço muito privilegiado para você ir encontrando outros diálogos, outros pontos de vista porque às vezes você fica sem entender uma situação ou uma coisa que alguma pessoa te disse e as visões de outros profissionais de outras áreas ou mesmo da sua vão te dando uma outra ancoragem, tentar pensar por aqui porque talvez te ajude a entender o que a outra pessoa queira o que essa pessoa quis dizer." (E14)
\end{abstract}

Conforme já comentado anteriormente, o atendimento às vítimas de violência carrega consigo dificuldades inerentes à temática em si. Em relação ao CRAVI, os temas da violência fatal e da vítima indireta parecem implicar em outras problemáticas relacionadas a esse lidar com a vítima:

"assuntos como as crianças em situações de risco, vulnerabilidade, das drogas, hoje em dia são assuntos muito discutidos, o homicídio ainda não é, ou é desse jeito entendeu, da mídia de mostrar o sangue e tudo isso, mas não é discutido na sociedade, é assim só em pequenos grupos. Então essa é uma diferença muito grande porque esses casos têm outros pontos de apoio porque se fala muito disso em muitos lugares, no caso de homicídio não, às vezes eles vêem o CRAVI como uma única referência para falar disso porque ninguém quer saber, a família não agüenta mais, no trabalho nem pensar, então tem poucos pontos de apoio, essa é uma grande diferença, às vezes ela chega aqui num ponto que é muito difícil para ela poder confiar que você vai ouvir e conseguir publicizar essa história na instituição pública, essa é a grande diferença." (E12)

"Quando a gente pensa que no CRAVI não tem divulgação, existe há dez anos e quase ninguém conhece, quando eu vou fazer uma análise mais macro eu vejo que isso é em toda a sociedade em relação a essa temática. Todo mundo que trabalha com essa temática tem muita dificuldade porque a gente vive em uma sociedade completamente alheia ao outro, as pessoas não querem saber do outro, só querem saber do outro no sentido de ter algum interesse principalmente econômico, politico, na sua conotação negativa e não positiva, então para que direitos humanos? Acho que as pessoas não imaginam, não faz sentido para a maioria das pessoas falar em direitos humanos." (E14) 
Para os profissionais da área jurídica do CRAVI, lidar com a vítima de violência apresenta outras conotações e dificuldades. A escassa troca com as outras áreas de atendimento da instituição ${ }^{165}$ e a formação jurídica - que não estimula a interação com outros saberes e profissionais, além de ignorar o tema da vítima de violência - resultam numa dificuldade de realizar o atendimento jurídico em si, pois lidar com a vítima de violência é desafiador.

"Tem uma certa dificuldade, até pela falta de informação do aspecto mais social e psicológico mesmo, então até por isso a gente solicita o apoio dos psicólogos quando a vítima ainda não está preparada, o crime às vezes é recente, porque é complicado às vezes a gente está dando uma informação fria de um processo, de um termo técnico, e a vítima ainda está bastante abalada e às vezes chora, é uma certa dificuldade que eu enfrentei no plantão do CRAVI." (AJ2)

Interessante notar que essa dificuldade para o jurídico lidar com vítima de violência foi apontado como mais complicada em relação ao acolhimento, atividade que convoca para uma atuação interdisciplinar.

\begin{abstract}
"Essa é uma boa questão [sobre como é lidar com vítimas de violência] porque conforme o desenvolvimento do trabalho do CRAVI fui me aprimorando e me familiarizando com essa temática, discutiu-se em reunião de eu não atender e sim acolher. O acolhimento é o processo inicial na recepção do usuário e eu acredito que o acolhimento é muito mais dificil que o atendimento. $O$ atendimento jurídico para as pessoas que tem formação jurídica é um atendimento sim pontual, na qual o advogado vislumbra o direito daquela pessoa e as possíveis medidas e ações judiciais que pode tomar. $O$ acolhimento no qual as pessoas não se identificam em termos profissionais e acolhem a vítima em um processo de escuta e de algumas colocações para que a pessoa realmente se coloque e ache todas as questões a partir do episódio violento, eu inicialmente disse que estava em processo de preparação para esse procedimento e não estava ainda confortável em fazer o acolhimento, atendimento jurídico sim, mas acolhimento ainda não. Então eu acredito que ainda lido com essa questão com um pouco de dificuldade" (AJ1)
\end{abstract}

Conforme mencionado anteriormente, o atendimento jurídico do CRAVI é realizado por defensores públicos; mas na equipe há um assessor jurídico, que não realiza atendimento jurídico às vítimas - atribuição dos defensores públicos que prestam serviço na instituição, em decorrência da parceria entre SJDC e DPESP. No atendimento esse assessor é responsável pela intermediação entre os defensores e os técnicos e usuários, pela busca de informações processuais e atividades externas do jurídico (que não podem ser realizadas pelos defensores durante o plantão). O assessor técnico jurídico é responsável pela "articulação institucional jurídica" do CRAVI e por demandas jurídicas da instituição.

\footnotetext{
"a proposta de trabalho do assessor técnico jurídico é que ele possa fazer a articulação institucional jurídica do CRAVI e em alguns casos, porque a Defensoria tem uma limitação de horário, por exemplo, à tarde ela não está disponivel, e têm alguns casos que é importante o acompanhamento do usuário, por exemplo, numa audiência, ou numa oitiva na delegacia, dependendo dos
}

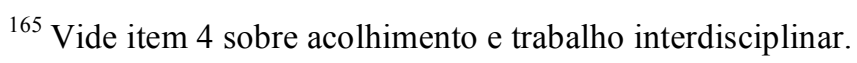


casos, não são em todos os casos que a gente desenvolve esse trabalho, dependendo do caso e do usuário é necessário. Nesses casos o acordo que nós temos com a Defensoria é, havendo necessidade e na impossibilidade da Defensoria acompanhar, esse caso vai ser passado para o assessor jurídico, ele vai analisar o prontuário, junto com o Defensor eles vão discutir o caso, vão marcar um atendimento com o usuário para se conhecerem e fazer um contrato de parceria mesmo que seja pontual para um acompanhamento e a partir disso ele faz esse acompanhamento pontual, não quer dizer que ele assume o caso a partir dali. É um trabalho em parceria com a Defensoria nos casos de acompanhamento externo." (E9)

"nós temos um advogado no CRAVI, mas ele não participa da parte de atendimento, ele faz o trabalho de rede, verifica nossos contratos e media a relação com os defensores e o resto da equipe, e ele participa das reuniões" (E11)

"Temos um advogado que (...) não vem para fazer atendimento, por conta da Defensoria não faz sentido fazer atendimento, mas diante das faltas da Defensoria, que às vezes acontece de chegar casos de urgência, a gente precisa dar uma resposta pro usuário e não ter defensoria, ele tem feito esse papel. Ele veio mais para fazer o jurídico no CRAVI enquanto instituição e não para atendimento (...) eu vou dar um exemplo, o CRAVI está construindo um regimento interno, então ele está cuidando dessas questões, processos para avaliar, dar parecer, coisas que o CRAVI pede, coisas mais burocráticas. Ele não vem fazer os atendimentos, mas de vez em quando ele está ajudando aí." (E10)

Esse trabalho de rede do jurídico consiste basicamente na sensibilização dos atores do sistema de justiça, por meio de palestras ou pelos contatos com delegados, promotores e juízes realizados no decorrer dos atendimentos, visando principalmente evitar a vitimização secundária.

"a rede do jurídico é informar que o usuário ou usuária que é normalmente mãe, pai ou irmão que tenha alguma relação de parentesco com a vítima, esses atores que seja informados que estão sendo atendidos pelo CRAVI e inclusive com a principal função de sensibiliza-los para o processo que aqui no CRAVI a gente chama de vitimização ou revitimização, que é um trabalho para que esses autores trazem pros usuários aqui no CRAVI ou abordem os usuários de uma forma diferente para que não ocorra novamente, já foram vítimas indiretas de um crime ou mesmo diretas, para que não sejam vítimas novamente" (AJ1)

"mesmo no contato da rede jurídica quando eu informo que o usuário está querendo falar com um promotor, com um juiz, ou quer ser atendido numa delegacia, e eu vou fazer esse contato pessoal com promotor, juiz, delegado, esse contato já é o inicio desse trabalho de sensibilização até por informar que a pessoa está sendo atendida no CRAVI, a conversa já inicia de uma outra forma." (AJ1)

Embora o direito tenha um lugar importante no CRAVI, o acesso à Justiça é precário e os direitos das vítimas parecem ser pouco divulgados, mesmo nos atendimentos. $\mathrm{O}$ atendimento jurídico é mais focado nas questões criminais - orientação jurídica sobre procedimentos, acompanhamento das investigações no inquérito policial, acompanhamento do processo criminal, eventualmente um pedido de desarquivamento de inquérito policial para orientação jurídica - raramente há encaminhamento para assistência jurídica em 
relação a outras demandas, como inventário, alvará, pedidos de indenização ${ }^{166}$, ou outra forma de reparação.

Em caso de encaminhamento para assistência judiciária, o defensor em plantão no CRAVI expede um ofício diretamente para a Defensoria Regional competente para as providências necessárias, sem que o usuário tenha que comparecer na triagem da Defensoria Central. No entanto, há pouquíssimo contato ou troca de informações entre esses defensores; o oficio de encaminhamento para a Defensoria Regional não menciona a situação de violência - com exceção de casos em que alguma questão jurídica deva ser justificada, por exemplo, no caso de ação de guarda proposta em foro diverso do foro de domicílio do autor, em razão de situação de risco provocada por violência doméstica. Essa falta de contato entre os defensores que atuam extraordinariamente no CRAVI e outros defensores públicos nos foros regionais foi apontada como uma dificuldade no trabalho e uma queixa entre os técnicos.

[sobre a troca entre os defensores públicos que atuam no CRAVI e que atuam
nas Defensorias Regionais] "Só os defensores do plantão, uma outra reclamação
que tinham os técnicos do CRAVI dessa limitação é que o CRAVI demanda uma
personalidade, a gente acaba tomando partido mesmo daqueles casos, a gente
conhece a família, a gente já sabe do que se trata, então se por exemplo em vez
de quatro, fossem cem defensores, ficaria bem complicado de você ter um
contato com aquele caso, saber do que é, então é mais complicado, por isso
cada defensor tem a sua lista de caso, só cuida daqueles e só amplia se receber
um caso novo, mas não passa de um defensor para outro. É um atendimento
mais complexo e mais demorado." (AJ2)

Fica a impressão de que a violência fatal, ou a violência doméstica ou sexual acarreta em questões penais, apenas. Quando na realidade, pode atingir tantas outras esferas de direitos da vítima, direta ou indireta.

Mesmo em relação à orientação sobre questões criminais, algumas informações parecem ser pouco difundidas. O contato entre o usuário e o promotor ou delegado responsável pelo processo ou inquérito relativo à violência em questão é promovido pelo jurídico do CRAVI apenas nos casos em que o usuário apresenta essa demanda de querer falar com promotor ou delegado, ou mesmo juiz ${ }^{167}$.

"Eu acredito que cabe pela fragilidade da vítima nesses momentos, pelo medo, pelo distanciamento que a maioria da população tem dos ritos jurídicos. $O$ assessor jurídico do CRAVI não vai lá para fazer nada, ele não vai lá defender a

\footnotetext{
${ }^{166}$ De acordo com as entrevistas realizadas, não foram propostas as ações indenizatórias pela Defensoria Pública (que parece aguardar a sentença condenatória no âmbito penal) e nem encaminhadas para parceiros; mas há casos mais antigos em que as ações indenizatórias foram propostas por uma organização da sociedade civil parceira.

167 Consideramos que a intermediação desse contato entre vítima e sistema de justiça pode não ser recomendada ou possível em todos os casos, mas o que emerge das entrevistas é que a possibilidade desse contato não é amplamente divulgado ou incentivado, mas apenas realizado nos casos em que o usuário solicita.
} 
vítima, ele não vai lá para representar, mas a presença daquela figura junto a vítima dá uma sustentação diferente, dá uma segurança diferente para vítima, essa construção de sentido que é importante, não é nem a representação, mas é a vítima poder se sentir segura, poder confiar no Estado de alguma forma, porque vamos supor, uma mãe de um rapaz que foi morto num confronto com a polícia, um processo que fica oito anos e não anda e quando anda o policial é absolvido. Qual é a confiança no Estado e na democracia que essa pessoa vai ter? Então nesse sentido, ter um agente público ao lado dela, com quem ela possa ter construído um vínculo, em quem ela pode confiar, ao lado de quem ela se sinta segura, isso dá outra qualidade ao trabalho, a imagem do Estado, a tudo." (E9)

"Esse contato é feito só nos casos em que o usuário traz essa demanda de querer falar com o promotor, ou de querer conhecer o juiz, ou querer falar com o delegado" (AJ2)

Para a equipe entrevistada, o direito no atendimento às vítimas de violência teria 0 papel de promover o acesso à Justiça e "portar a lei” em relação à violência. A orientação sobre os direitos e os procedimentos jurídicos envolvidos no exercício desses direitos, o acompanhamento do inquérito policial ou do processo criminal para informar as vítimas sobre o andamento do caso, além de consultas sobre dúvidas jurídicas da equipe técnica foram apontadas como atribuições jurídicas.

"Eu acho que a primeira função que é muito importante é a função da orientação, mas uma orientação com as delicadezas do trabalho, não dá para o advogado ser só advogado, ele tem que entender todo esse contexto da vítima. Acho que a segunda é acompanhar o processo e poder junto com esse usuário trazer a compreensão dos trâmites da justiça, é interessante porque é onde dá para esse sujeito se enxergar, o que ele pede da justiça e o que essa justiça não vai dar conta. Então um bom trabalho jurídico traz essa fronteira e ajuda nessa fronteira, que é onde outras áreas entram. É muito comum o pedido por justiça ser um pedido de vingança. Um bom trabalho jurídico nesse sentido de orientação e acompanhamento dá para delinear essa fronteira e ajudar esse sujeito a perceber isso. Acho que o outro trabalho do jurídico também é trazer essa discussão para a equipe, contribuir nesse sentido porque os psicólogos e o pessoal do serviço social não temos o saber que o jurídico porta, então o jurídico pode contribuir muito na reflexão da cidadania, direitos, direitos humanos, um saber que é importante estar junto." (E13)

"O direito é a área que mais promove o acesso à justiça, às vezes até físico, muitas vezes os advogados do CRAVI saem do CRAVI para acompanhar o usuário, falar com o promotor, com o delegado, talvez um pouco educativo mesmo porque acho que a tentativa é que o usuário se aproprie desse saber ou desse movimento para que ele mesmo possa fazer." (E12)

"Mesmo no imaginário, para as pessoas atendidas no CRAVI o advogado é uma figura muito importante e acho que se souber usar bem dessa transferência e muitos dos usuários têm com o advogado ajuda muito em relação a esse acesso à justiça mesmo, até às vezes os usuários que chegam falando de um desejo de vingança e quando o advogado mostra as possibilidades, além das dificuldades desse acesso à justiça, acho que faz uma função muito importante, portar a lei mesmo. Eu acho que isso de portar mesmo a lei é muito interessante, de falar isso é possível, isso não é possível, porque o psicólogo ainda vai construir de acordo com o tempo da pessoa, mas como tem uma transferência com o advogado que é quem vai portar a verdade para mim, é ele quem vai dizer: isso pode, isso não pode, isso é proibido, isso é permitido. Isso é muito importante nessa área da violência, as pessoas estão inseridas já em engendramentos da violência e acabam repetindo a violência também, acho que é essa mesma, de 
portar a lei realmente como acesso à justiça. (...) A pessoa pode chegar e falar “eu quero só ter um advogado para que faça andar mais rápido o processo", as pessoas acham que tendo advogado anda mais rápido o processo, o advogado poderia através dessa legitimidade da lei falar que isso não, tem um tempo,é mais no sentido de orientação mesmo, mas sempre falando o que pode e o que não pode, é possível." (E12)

"o que se espera do atendimento jurídico do CRAVI é que o cidadão fique esclarecido quanto ao seu acesso à justiça, às reais possibilidades, ao funcionamento do judiciário e das polícias, o real funcionamento, de como ele pode participar ou não, e onde participar ou não, que ele tenha clareza sobre como está andando o processo e direções que estão acontecendo no processo em concreto que está em andamento, e que seja tratado como muito respeito e dignidade. Acho que se o jurídico fizer isso, aí estou pensando que ele não está participando do grupo de cidadania ainda, mas se o jurídico fizer isso acho que ele está promovendo muito fortemente uma difusão dos direitos humanos porque entender como funciona o sistema de justiça significa poder reclamar seus direitos, saber quais instrumentos." (E11)

"Acho que vocês oferecem também esse outro lugar para essa pessoa, esse lugar social que é em relação a todas essas normas que a gente tem no sentido de uma sociedade poder conviver de uma forma melhor. Mesmo as pessoas que não acreditam que é possivel, porque as pessoas chegam aqui muito desesperançadas em relação à justiça, em relação à violência, em relação às leis, em relação eu diria às responsabilidades de cada um. Para mim a gente mora em um país, num mundo aí que tem uma irresponsabilidade e eu acho que é um pouco esse papel que vocês têm aqui dentro, de poder dizer para as pessoas: "É dificil, mas tem leis, tem possibilidades, tem por onde, por mais difícil que seja." Eu acho que esse acesso aos direitos também, vocês desvendam um caminho para as pessoas que é muito obscuro, as pessoas não sabem como caminhar por dentro de toda essa coisa da polícia, do judiciário, enfim, eu acho que vocês vão desvendando esse caminho para as pessoas, o que faz com que as pessoas se sintam mais participantes dessa sociedade nesse recorte. Eu acho que vocês proporcionam isso e acesso aos direitos e a esses novos lugares, a essa nova participação social, esses encontros então com os promotores são fantásticos as pessoas voltam de outro jeito, às vezes elas ouvem umas coisas absurdas dos promotores e a gente fala: "Como esse cara falou isso para essa pessoa?", mas tem gente que fala: "Ainda bem que ele falou isso para mim." É diferente se a assistente social, uma psicóloga ou uma advogada falasse, é aquele cara, o promotor tal, que representa 30 milhões de coisas, que fala coisas duríssimas, mas a pessoa sai de lá de outro jeito, muitas vezes falam de um outro lugar. (...) Eu acho que o que a gente tenta fazer, e o jurídico também e as outras áreas, é ir dizendo para essas pessoas que elas têm como participar dessa sociedade em que elas vivem, que elas não estão submetidas a isso tudo, que elas têm e podem ter voz, que elas podem participar e fazer de forma diferente, a maior missão do CRAVI é essa. Quando eu falo de direitos eu estou falando de Direitos Humanos e de direitos de uma forma geral." (E14)

O papel do direito apontado pelos técnicos é focado na orientação aos usuários. A atuação no contencioso é raramente realizada ${ }^{168}$ : não há intervenção no processo penal em que a violência é julgada e de acordo com o caso há encaminhamento para assistência judiciária para interposição de ação judicial pertinente. O contato com os atores do sistema

\footnotetext{
${ }^{168}$ Para o defensor público, uma participação formalizada no processo penal é desnecessária: “como a gente atua prioritariamente em casos de homicídio não acho tão importante assim, a eventual sentença condenatória no final processo a gente já vai partir para a esfera cível ou sem prejuizo disso, pode fazer antes também, não acho que seja tão decisivo assim. " (AJ2)
} 
de justiça é realizado para intermediar a relação entre usuário e promotor de justiça ou delegado de polícia.

"nossa atuação lá é mais informativa mesmo, passar as informações e a demanda é pouca assim, a gente entra com casos excepcionais mesmo, é mais aspecto de informação, explicar as fases do processo, o que está sendo feito, o que é uma sentença de pronúncia, o que é impronúncia, fases de investigação, é mais informativo mesmo. (...) caso haja necessidade, nós mesmos fazemos a eventual ação de reparação de danos, essa parte de compensação mesmo, e embora a gente não atue no processo penal mesmo, eu pelo menos não tive nenhum caso de atuação eventualmente como assistente de acusação ou alguma coisa nesse sentido no processo penal mesmo, mas a gente às vezes intermediou encontro dos familiares com o promotor do caso, (...) a gente expede um oficio para o Ministério Público solicitando essa reunião e comparece também, quando é necessário. Mas essa atuação no processo criminal mesmo, eu não tenho notícia." (AJ2)

“a maior demanda deles é o que está acontecendo, como está a investigação, o que vai acontecer, as próximas fases, é mais informação mesmo, eu mesmo nunca tive um caso de reparação de danos" (AJ2)

A orientação jurídica não se resume a simplesmente informar sobre os direitos da vítima, o advogado ou defensor público não pode ser "só advogado", é preciso entender sobre a situação da pessoa vitimada, sobre o contexto social e familiar, é necessário ter em mente a finalidade do atendimento no CRAVI. O direito no atendimento às vítimas de violência não é apartado das demais áreas de atendimento.

[sobre o advogado não ser só advogado] "Não existe algo ainda sistematizado e pronto, mas tem uma questão de chegar no CRAVI e conversar muito com os técnicos acerca disso, poder entender as outra áreas, pode entender como essa vítima chega e juntar esses conhecimentos e a outra parte é a partir da prática mesmo, não tem como. (...) uma das formas de trabalhar isso é nas discussões dos casos, encaminhamentos, nas discussões sobre a instituição, seria muito importante que a Defensoria participasse das reuniões junto a equipe do CRAVI, coisa que não vem acontecendo, nas discussões de caso a caso, nas discussões sobre posicionamento do CRAVI isso aparece e o advogado tem total liberdade para poder conversar com a gente sobre as dúvidas, sobre as dificuldades que eles sentem. Uma das coisas interessantes que a gente conversa muito sobre a atuação dos advogados é que às vezes o advogado é afetado pela prática e como ele se cuida?" (E13)

"Eu faço uma crítica à nossa formação, Nós somos muito pontuais, nós não trabalhamos tanto com o sujeito, como é um objeto talvez da psicologia, da psicanálise, e nós também não fazemos um histórico tão grande, que talvez seja objeto do serviço social, do lugar daquela pessoa, daquelas condições, a gente só vê as condições para ter um atendimento gratuito ou não, gratuidade da assistência judiciária, e pronto, pode fazer uma declaração ou outro pedido nesse sentido. (...) angústia, condições do sujeito, será que ele vai dar conta, será que vai tomar as rédeas da vida, enfim, essas questões sim me servem no atendimento jurídico para também vislumbrar que há necessidade de encaminhar para a psicologia ou para o serviço social, agora só esse fenomeno, no atendimento jurídico, em termos pontuais e para trabalhar mais com prática e processo, eu não vejo operar com interdisciplinaridade a não ser nesse aspecto de haver necessidade ou não, numa análise bem simples de se pensar que há a necessidade de encaminhar para uma área ou outra (...). Se fosse fora, se o usuário tivesse o atendimento aqui só e fosse para um jurídico fora, em um escritório de advocacia, por exemplo, o escritório de advocacia iria eliminar toda essa escuta, toda essa parte da psicologia e serviço social e ia tomar as 
providências e ações ou ia vislumbrar os direitos dessa pessoa em relação ao Jurídico. Aqui como há essa possibilidade, esse trabalho interdisciplinar então o jurídico tem que ter isso em mente e não pode deixar de dar, dissociar quando vê que há uma questão que pode ser trabalhada em outra área e encaminhar, não pode e nem tem a prepotência de tentar lidar com isso porque talvez a pessoa com formação jurídica às vezes se julgue que possa, ou que tem domínio para isso ou acha que "isso não vem ao caso", esquece, deixa de lado, tem que ter ciência das outras demandas, que na escuta o usuário pode trazer isso como demanda, e encaminhar para as outras áreas, nem iniciar e nem tentar trabalhar com isso." (AJ1)

" A escuta do advogado ou Defensor não é uma escuta muito perspicaz, técnica, muito aguçada porque realmente não domina essa área, então eu acho que o advogado ou Defensor tem que se capacitar para fazer uma escuta, não é para qualquer um. Se você for em um escritório privado em outra área não vai nem haver escuta, na verdade o jurídico vai perguntar porque quer saber fatos, datas, para fundamentação ou tese para conseguir um êxito numa ação ou trabalhar na defesa, aqui a escuta tem que ser diferenciada, do defensor ou mesmo do advogado, tem que ser uma escuta, não uma escuta clínica como das outras áreas, mas uma escuta que conforme for escutando precisa ter em mente que há outras áreas, as demandas para as outras áreas, as queixas que ele está trazendo devem ser notadas, não podem ser deixadas de lado." (AJ1)

Entretanto, conforme já mencionado, o formato da parceria entre SJDC e DPESP não favorece uma efetiva integração entre os técnicos e o atendimento jurídico.

\footnotetext{
"eu não vejo uma tomada de decisão dos Defensores de pensar que no atendimento com esse usuário está trazendo outras demandas e encaminhar, não só porque eles não tem capacidade, e acho que também eu tenho um pouco mais, porque eu estou me capacitando com as reuniões, com os casos, conforme fui escutando e teve apresentações tanto da metodologia do serviço social como tem textos na rede sobre metodologia da psicologia, então eu não fui capacitado por cursos, mas fui capacitado na prática pelo dia-a-dia. Mas os defensores não, e por eles estarem aqui pouco tempo, eles estão das $09 \mathrm{~h}$ às $12 \mathrm{~h}$, eles têm vinte casos cada um, se eles vão atender uma hora um usuário como eles vão fazer nesse tempo, nessa uma hora de atendimento, para enxergar as outras demandas? Eles não vão se preocupar, eles só vão se preocupar com o que esse usuário vai trazer de informações que possam auxiliar na fase de inquéritos e na fase de processos, então há uma falha também." (AJ1)
}

Com a criação da Defensoria Pública em 2006, foi firmada uma parceria entre o Governo do Estado e Defensoria Pública para a realização de atendimento jurídico por defensores públicos em todos os órgãos do Governo do Estado que mantinham departamento jurídico com atendimento à população. Nesse contexto, os advogados que trabalhavam no CRAVI foram afastados dos atendimentos, que passaram a ser realizados por defensores públicos, em regime de plantão. O contrato inicial vigente no primeiro ano dessa parceria tinha a previsão de uma equipe composta por quatro defensores públicos, que atuariam no CRAVI em regime de plantão, durante três horas no período da manhã, realizado quinzenalmente, por período de seis meses. A partir de novembro de 2008, esse contrato foi rediscutido para adequação ao trabalho desenvolvido no CRAVI e contemplou seis defensores públicos, em regime de plantão, desta vez semanal e por período de um ano. 
A seleção dos defensores públicos para atuação no CRAVI é realizada por meio de sorteio entre os interessados que se inscrevem durante um prazo determinado pela Defensoria. Não há requisitos para a inscrição, nem entrevista com os interessados. São sorteados os defensores que formarão a equipe e seus suplentes. A atuação dos defensores públicos no CRAVI é realizada em regime de plantão, o que significa que o defensor tem uma dupla opção: pode escolher entre compensar com um dia de trabalho ou requerer a gratificação no percentual de 5\% dos vencimentos dos defensores públicos de nível I.

A equipe da Defensoria Pública havia sido recepcionada na instituição no primeiro plantão, ocasião em que houve uma apresentação sobre o CRAVI e uma breve explicação sobre as atividades desenvolvidas e os casos em acompanhamento pelos defensores da equipe anterior ${ }^{169}$. A proposta do novo formato de parceria entre SJDC e DPESP era de que a recepção da equipe de defensores públicos (que ingressou em novembro de 2008, com regime de plantões semanais e com atuação durante um ano) fosse realizada numa reunião geral com toda a equipe do CRAVI.

\begin{abstract}
"No caso do CRAVI, quando eu comecei não teve essa palestra, mas teve o primeiro plantão no CRAVI foi a passagem de casos, então a defensora que me antecedeu explicou o funcionamento do CRAVI e relatou caso a caso, que ela estava acompanhando, o que ela fez, o que estava pendente, o que tinha que fazer, enfim para a gente conhecer mesmo a lista de casos. (...) está marcado um encontro de todo mundo, equipe nova e antiga e a passagem de casos, que é quando a gente informa como é o funcionamento do CRAVI, os oficios, a nossa atuação e informa mesmo a nova equipe dos casos que assumirão. (...) Quando eu comecei foi só com a defensora que me passou os casos, foi uma reunião normal só entre eu e ela, mas parece que agora com a nova equipe vai ser uma reunião geral, com todos os técnicos do CRAVI" (AJ2)
\end{abstract}

Vale ressaltar que até 2007, antes dessa parceria com a Defensoria Pública, o núcleo jurídico ${ }^{170}$ do CRAVI contava com advogados na equipe, os quais participavam de todas as atividades da instituição, em regime integral. Os advogados participavam do

169 Os defensores públicos em atuação extraordinária no Cravi tinham casos antigos repassados pelos defensores da equipe anterior e recebiam casos novos durante o período de atividades no Cravi. "Os casos antigos foram encaminhados pelos Defensores antigos para Defensores novos, então os que eram dos Defensores de terça passam para os Defensores de terça, os casos que eram de quinta passam para os de quinta, esses para os casos antigos. Os casos novos são encaminhados de acordo com a data que o usuário vai querer fazer o atendimento no jurídico" (assessor jurídico)

170 No início da instituição havia uma parceria com a Procuradoria Geral do Estado para realização de atendimento jurídico no Cravi, desde a sua fundação em 1998, com presença diária dos procuradores que se rodiziavam anualmente. Essa parceria, concretizada em plantões realizados por procuradores da Procuradoria de Assistência Judiciária se manteve até meados de 2003. Os procuradores faziam atendimento jurídico duas vezes por semana, um período do dia, e não participavam das outras atividades do CRAVI. Em 2001, houve a contratação de advogado e estagiários para atendimento jurídico às vítimas de violência. Na medida em que o núcleo jurídico, formado por advogado e estagiários contratados pela ONG conveniada, se fortalecia e se integrava na instituição, o trabalho desenvolvido pelos procuradores foi perdendo sentido, até o término da parceria em 2003. Desde então o atendimento jurídico passou a ser realizado somente por advogados e estagiários, até final de 2007, quando o atendimento jurídico do CRAVI passou a ser realizado somente pelos defensores públicos. 
acolhimento, realizavam atendimentos, participavam das reuniões de equipe e de supervisão institucional, dentre outras atividades. Em 2004, os advogados do CRAVI acompanhavam o inquérito policial, processo criminal na Vara do Júri e em alguns casos representam a vítima em casos de inventário, arrolamento ou expedição de alvará judicial. A orientação jurídica era realizada em todas as matérias do direito, visto que os familiares atendidos muitas vezes não conhecem seus direitos e procedimentos necessários para exercê-los. Além disso, buscava-se contribuir na resolução de questões como a inserção da vítima no processo penal, a sensibilização dos agentes do sistema de justiça e os operadores do direito sobre a questão das vítimas, a fim de se evitar a vitimização secundária.

Em linhas gerais, os advogados tinham as seguintes atribuições:

a) Orientação a todos os casos e temas trazidos pelos familiares de vítimas de homicídio, com o objetivo de que o usuário estivesse ciente dos seus direitos e dos meios de exercê-los, para com isso poder reivindicá-los nos endereços corretos. Essa orientação era realizada de acordo com solicitação do usuário e/ou dos técnicos da equipe. A orientação jurídica era realizada primordialmente sobre as principais questões decorrentes da morte violenta: aspectos penais (a fim de informar e sensibilizar a família sobre o acesso à Justiça, às informações sobre andamento do inquérito policial ou processo etc); aspectos de natureza civil (verificar necessidade de inventário ou alvará, informar sobre possibilidade de indenização em âmbito civil, dentre outros); aspectos trabalhistas (verificar se a vítima direta tinha algum direito trabalhista e como a família poderia acessálo) e previdenciários (especialmente em relação a pensão por morte). A orientação era um importante instrumento para informar a família sobre os direitos existentes e suas formas de exercício, como uma forma de acesso à Justiça.

b) Encaminhamento para assistência judiciária gratuita ou outros serviços, quando necessário. Os encaminhamentos exigiam a parceria com centros de assistência judiciária e eram realizados principalmente em relação às demandas jurídicas nas quais os advogados não atuavam diretamente, tendo em vista o recorte da violência fatal.

c) Consulta em casos em que o núcleo jurídico não estava diretamente envolvido no atendimento, mas ficava na retaguarda para informação aos técnicos - seja enquanto usuários não fortalecidos, seja porque intervenção jurídica direta pelo advogado da instituição se mostrava desnecessária no momento. Tal ação exigia a discussão entre os técnicos sobre o atendimento prestado, encaminhamentos e propostas ao caso. 
d) Acompanhamento de inquérito policial e processo crime. Grande parte dos inquéritos são arquivados sem autoria conhecida e apenas uma ínfima porcentagem chega a condenação final no Júri; a vítima não participa do processo, a não ser quando arrolada como testemunha. Dessa forma, a vítima não tem conhecimento sobre o andamento do processo, o que aumenta a sensação de impunidade e descrença nas instituições. Os usuários do CRAVI, vítimas indiretas do homicídio, eram informados do andamento processual e também dos procedimentos e direitos envolvidos - o que possibilitava a sensibilização sobre universalidade dos direitos, garantias processuais, dentre outros aspectos. $\mathrm{O}$ discurso de vingança era bastante presente nos relatos dos familiares e muitas vezes condicionado à ineficiência do sistema de Justiça formal. A justiça desejada às vezes se confundia com vingança, contrapondo-se a uma Justiça divina ou ao sistema de justiça formal. As garantias processuais eram vistas pelos usuários como "injustiças" porque confundidas com a emoção da vítima - daí a importância de um atendimento interdisciplinar. Nesse sentido, a educação em direitos humanos parece estar presente no trabalho de cada um dos técnicos, seja qual setor.

Outra atuação possível era em relação à possibilidade de vitimização secundária sofrida pelas vítimas, o que alerta para a necessidade de sensibilização dos agentes do sistema de justiça, a fim de envolver os diferentes atores da polícia, peritos e funcionários do Instituto Médico Legal, representantes do Ministério Público e do Judiciário no combate à vitimização secundária e na composição de um atendimento qualificado nas diferentes instituições. Também era importante ressaltar junto aos familiares a necessidade de provas suficientes de autoria e materialidade para condenação do réu; esclarecendo sobre os direitos do acusado e a garantia de um processo imparcial e justo. A partir do atendimento às vítimas, em alguns casos era possível identificar eventuais testemunhas e outras provas a serem levadas aos autos a fim de colaborar com a elucidação do crime, respeitando-se o papel e atribuições de cada ator do sistema de justiça e tomando-se o devido cuidado em relação a possibilidade de riscos e ameaças. Assim, os advogados atuavam também como uma "ponte", um canal de comunicação entre vítimas indiretas e o Judiciário, a fim de levar a voz das vítimas ao processo e dar visibilidade à questão dos direitos humanos e das vítimas. ${ }^{171}$

\footnotetext{
${ }^{171}$ Para maiores informações, ver Linguagem e efetivação dos direitos humanos: o desafio do direito no atendimento interdisciplinar a vítimas de violência, monografia apresentada em 2004 ao Curso de Especialização em Direitos Humanos da Faculdade de Direito da Universidade de São Paulo, como parte dos requisitos para obtenção de titulo de especialista em direitos humanos.
} 
O modelo atual do jurídico foi bastante criticado nas entrevistas, especialmente em relação à pouca permanência dos defensores públicos no CRAVI e à falta de integração do trabalho.

"Eu acho que esse modelo, eu não sei se é porque a gente já está acostumada com o modelo anterior, mas eu acho que esse modelo pode até funcionar com algumas adequações, uma construção. Umas das coisas que a gente acha que ajudaria muito é se fosse uma equipe fixa que tivesse todos os dias no CRAVI, não através de plantões e que a gente pudesse conversar com esses defensores, trocar, eles conhecerem um pouco mais dos atendimentos porque o que fica para mim é que o tipo de trabalho que a Defensoria desenvolve em outros locais, não cabe no CRAVI. A gente costuma até brincar que eles teriam que se adequar à instituição e a gente sente, não é que tem uma resistência, mas eles têm perfil, uma metodologia de trabalho que não agrega pro CRAVI, teria que ser mudado, aperfeiçoado, discutido. Não depende nem dos defensores e nem da gente, depende da coordenação do CRAVI e da direção da Secretaria, é uma conversa em outra instância." (E10)

"Sabe que eu fico pensando, porque uma das missões do CRAVI é que esse usuário tenha acesso à justiça, que ele tenha voz e isso sendo feito através da Defensoria parece que não está sendo possivel, esse acompanhamento com promotor, enfim, acho que isso não está sendo feito através da Defensoria, por conta da pela metodologia de trabalho deles, é tudo muito corrido, não tem tempo de acompanhar os usuários, acho que fica uma coisa dificil, uma coisa muito mais pontual, o atendimento deles é muito pontual, prático." (E10)

"O trabalho da Defensoria é muito multidisciplinar e não inter, por enquanto ainda está um pouco descolado. Eu sinto o atendimento da Defensoria é muito pontual e muito diferente, por exemplo, da atuação de um advogado para atender dentro do CRAVI, era muito diferente. A gente tinha a possibilidade de poder discutir a intervenção com o advogado, como as linhas podiam uma colaborar com a outra, como que os saberes se interpunham no atendimento e nas questões que esse atendimento geram, (...) foram muitas conversas, eu sinto uma diferença enorme, do momento que eu atendia para o momento atual, a Defensoria é multidisciplinar e não inter, o atendimento é mais pontual." (E13)

" $O$ vínculo de confiança que o usuário vinha estabelecendo com o jurídico do CRAVI, ele estava muito fortalecido, muito fortalecido mesmo, e hoje esse vínculo é não é eficaz, porque muda a cada seis meses. Então o defensor faz só um contato ou dois, quando vê já mudou, porque a Justiça é lenta então não é todo mês que você tem uma novidade para poder passar para o usuário. A minha preocupação é que a proposta do jurídico não é só de acompanhar o caso, não é só de dar informação sobre a ação, não é isso, mas é um trabalho sócio-educativo junto ao usuário, então essa escassez, esses períodos curtos de plantão, essa dificuldade de construção de vínculo impossibilita o trabalho sócio-educativo junto ao usuário. A compreensão sobre direitos, sobre direitos humanos, fica prejudicada, não digo que não aconteça, acontece, mas fica prejudicada." (E9)

"A defensoria tem informado, mas há uma questão de menos mão-de-obra do que a demanda, está aquém do que eles podem mesmo, não é má vontade ou falta de escrúpulos ou qualquer coisa do gênero, mas são três horas a cada 15 dias e cada um tem 30, 40 casos, não dá tempo." (E11)

"O trabalho da Defensoria Pública aqui nesse questão de choque de contexto é muito dificil e o modelo aqui inserido de plantão de $15 \mathrm{em} 15$ dias não é o ideal já que os usuários aqui aparecem todos os dias e para o caso ser encaminhado, após o encaminhamento e até o Defensor tomar ciência e entrar em contato com o usuário realmente vai ser de 15 em 15 dias e às vezes há uma emergência, há uma audiência então o atendimento no modelo daqui não é o mais adequado e não é o melhor, mas é o que foi proposto e é com o que nós temos trabalhado. 
Nessas reuniões de equipe sou informado de muitas angústias e devolutivas tanto dos usuários como dos técnicos sobre o trabalho do jurídico aqui, da Defensoria, a demora no contato, a demora em alguma resposta porque eles realmente estão aqui a cada 15 dias, fazem um trabalho bom quando estão aqui, quando não estão aqui e não há possibilidade de continuar o trabalho... se bem que alguns Defensores acabam trabalhando fora do expediente, atendendo usuários na sua sala da Defensoria nas dependências do Fórum ou marcando no CRAVI da unidade do fórum para tentar dar conta, porque realmente eles só estão aqui de quinze em quinze dias. " (AJ1)

Essa mudança da atuação dos operadores do direito no CRAVI foi encarada pela equipe técnica como uma perda na qualidade dos atendimentos realizados. Uma insatisfação com esse descompasso gerado na linha de atuação do jurídico, após a parceria com a Defensoria Pública, emerge claramente nas entrevistas.

\begin{abstract}
"Eu acho que tava trabalhando bem... Acho que o Direito tinha encontrado um caminho interessante de desenvolvimento do trabalho, uma atenção diferenciada à vítima porque normalmente o Direito as pessoas dizem que é uma área seca. A lei, a regra e a proposta do jurídico do CRAVI era humanizar um pouco mais essa relação advogado usuário, e isso estava se desenvolvendo de forma eficiente na minha opinião. Os atendimentos eram feitos, por exemplo, psi e jurídico junto, social e jurídico junto e isso acabava fortalecendo a equipe, fortalecendo o trabalho, a possibilidade de articulação entre as instituições também era diferente, mesmo nessa questão daqueles 20 ou 30\% que eu falei que são vítimas de ação estatal, nesses casos o jurídico do CRAVI conseguia uma força maior, uma articulação maior com outras instituições que tivessem mais liberdade ou mais legitimidade para poder trabalhar com essas questões e eu acho que com a substituição do jurídico do CRAVI pela Defensoria, esse valor nós perdemos." (E9)

"Tudo isso, toda essa riqueza dessa construção do trabalho do jurídico interdisciplinar, a gente perdeu, não que a gente tenha esquecido do que era, ou que a gente não precisa mais, eu falo de uma perda porque a gente sabe da importância, amputou um pedaço do trabalho do CRAVI para mim, não tem essa relação com a Defensoria, não é a mesma coisa, eles não se colocam como alguém da equipe, é outra instituição aqui dentro fazendo um trabalho junto, é fragmentado, é um diálogo de especialistas cada um no seu mundinho e fechadinho na sua caixinha, não é um diálogo de uma equipe de trabalho." (E6)

“[Quando tinha advogado aqui vocês trocavam mais?] O tempo todo, então dá para dizer que havia uma de transposição de saberes para poder chegar em um atendimento, para poder ter um atendimento consistente, hoje eu não vejo, vejo o jurídico muito descolado, meio sozinho. Talvez no futuro possa ser diferente, mas hoje eu vejo dessa forma." (E5)

[sobre a falta de diálogo com os defensores] "Faz diferença e uma falta, vou ser categórica, faz diferença e uma falta muito grande, no meu ponto de vista, não sei se os técnicos todos pensam assim, no meu ponto de vista é muito diferente hoje, tinha uma qualidade maior nos atendimentos na minha opinião, quando a gente podia fazer essa atuação juntos, psicologia e jurídico, serviço social e jurídico, a gente tinha essa transposição de saberes, eu acho que era um ganho para o usuário." (E13)
\end{abstract}

Parece que mesmo uma instituição pública, com 10 anos de atuação, sofre com a descontinuidade da linha de atuação - provocada, às vezes, ao sabor de determinações políticas. Para contornar essas quebras, a instituição tenta traçar algumas alternativas. A figura do assessor jurídico possibilita que algumas consultas pontuais e atuação em casos 
emergenciais; o contrato com a Defensoria Pública foi avaliado e incluir mais defensores, por um período maior e com maior freqüência.

\begin{abstract}
"A tentativa é que com a presença pelo menos desse articulador jurídico a gente possa amarrar alguma coisa, mas não é a proposta que nós tínhamos. Só que a política pública fica suscetivel a determinações políticas, algumas vezes eficazes, outras paliativas, outras desastrosas, eu não acho que seja desastroso também, não é esse o caso. Não posso dizer que é impossivel trabalhar nesses moldes com a Defensoria, talvez com um tempo maior da Defensoria aqui nós pudéssemos resgatar alguma coisa, mas com um atendimento a cada 15 dias é muito difícil, mesmo o vínculo com o usuário é mínimo." (E9)

"Estamos num momento de revisão desse contrato e parece que eles estão dispostos a rever, a mudar o que está em vigor, para no próximo já entrar com outro contrato com mais horas por semana no CRAVI, podendo discutir com a equipe, se assenhorear e trabalhar, não passar seis meses e quando tem oportunidade de entender as coisas vai embora. Não adianta, não é nada funcional, mas é o que é possivel no momento. Mas quando os defensores conseguem fazer o trabalho, têm feito trabalhos legais de atendimento interdisciplinar que foram muito interessantes, a pessoa tinha uma audiência e ai o defensor explicou direito o que ia acontecer na audiência, quais seriam as possibilidades, como a pessoa tinha que falar, a pessoa falou "posso falar isso?", uma orientação técnica e é muito importante." (E11)
\end{abstract}

Notamos que há uma preocupação da instituição com o atendimento jurídico prestado e uma mobilização para que as demandas jurídicas das vítimas de violência sejam devidamente encaminhadas. Entretanto, há outras variáveis que tornam a questão ainda mais complexa. A vítima é quase invisível para o direito. Há alguns centros de atendimento às vítimas de violência, mas nem todos prestam atendimento jurídico e intervém nos processos judiciais. No sistema de justiça a vítima não ocupa um lugar definido - no processo penal, ela existe, mas não precisa ser identificada; a vítima não é ouvida, a não ser quando é testemunha e produz prova; algumas de suas características são consideradas para fixação da pena em caso de condenação penal.

"Então a pergunta é: "A vítima é para ser trabalhada com quem?" Eu faço um
recorte ai da nossa legislação, a nossa legislação penal e processual penal tem
a vítima primeiro para análise do crime, para valoração ou diminuição da pena.
A vitima está inserida, há casos de aumento de pena, quando a vítima é maior de
60 anos, há casos de diminuição de pena, quando a vítima está numa condição
descrita no código. E mesmo no estudo de Vitimologia (...), era o ramo da
criminologia na qual nos seus primórdios de estudo da escola clássica, escola
positiva existia uma tríade: delinqüente, pena e crime. Então a vítima não
estava nesse contexto, a vítima foi inserida depois, mas mesmo assim nos
estudos da Vitimologia tem autores que falam da vítima provocativa, da vítima
que deu causa ao crime. Então o papel da vítima dentro do Estado é complicado
porque os atores que mencionei trabalham com ela como instrumento de prova,
e os Defensores Públicos também; porque quando há o crime a vítima trará
elementos para o MP tentar condenar e para os Defensores tentar absolver." (AJ1)

Nesse contexto, a vítima é praticamente ignorada e o atendimento jurídico enfrenta desafios ainda mais complexos na medida em que quase não há instrumentos jurídicos para a defesa dos direitos das vítimas (os quais são desconhecidos pela maioria dos operadores 
do direito) e efetivo acesso à justiça. A atenção às vítimas parece se concentrar na questão da vitimização secundária que sem dúvida é relevante, mas não abrange todos os direitos das vítimas ${ }^{172}$.

\begin{abstract}
"Eu acho que a forma como a vítima é tratada pelo Estado e esse papel da vítima dentro do processo podem operar de forma positiva ou negativa na vitimização, na forma como a vítima é abordada por esses atores institucionais ou como ela é tratada dentro do inquérito e dentro do processo isso ajuda ou dificulta, gera ou não o processo de vitimização secundária. Então o trabalho de sensibilização com esses atores é nesse sentido, mas é muito dificil mudar esse contexto, (...) a visão de vítima desses atores, delegado, promotor e juiz era essa, que a vítima para eles, primeiro que só chega a eles porque é uma testemunha, se a vítima não é uma testemunha, nem nesses locais ela comparece, então ela fica lá realmente apagada, ela não é descoberta, fica lá talvez sofrendo como episódio violento, e mesmo tendo sido testemunha, às vezes testemunha ocular, mas ela não é inserida no processo como testemunha. (...) uma falha gravissima trata-la como instrumento de prova, ou seja, ela serve para o Ministério Público para pedir a condenação do réu ou para aumentar a pena e inserir uma qualificadora, ótimo, senão dispensa-se, então ela é ouvida pelo Ministério Público, é ouvida pelo juizo, pelo juizo nem tanto porque o juiz não quer só a prova das testemunhas mas também quer a prova também do réu, enfim, mas Ministério Público e mesmo a polícia, é muito grave tratar a vítima nesse papel como instrumento de prova, então a vítima para a polícia trará indícios, a vítima para o Ministério Público trará provas." (AJ1)
\end{abstract}

O discurso de direitos humanos é presente e definido na fala dos técnicos entrevistados. Há um consenso de que o trabalho desenvolvido no CRAVI visa promover os direitos humanos, especialmente em relação ao acesso à Justiça e à divulgação dos direitos.

\begin{abstract}
"Eu acho que é um trabalho de promoção dos direitos humanos e de democracia mesmo porque o convite é que tenha nas três áreas de atuação no atendimento direto à população é ensinar a escutar também, escutar a si mesmo e escutar o outro que é uma arte fundamental na democracia, não é falar, é falar e ser escutado, ter interlocução." (E11)

"Considero, eu acho que é uma forma de promover o acesso à Justiça mesmo, (...) principalmente nessa área criminal de vítima, fica muito a cargo do Ministério Público, que tutela a pretensão do Estado de punir o individuo e a vítima às vezes fica desamparada, até por essa característica de que no fórum criminal a gente atua em favor do réu então as vítimas às vezes se sentem desamparadas e acho que no CRAVI, pelo menos, é uma forma de tutelar o acesso à justiça como direito humano, mesmo porque a gente não atua só no crime, a gente propõe as demandas civeis, então eu entendo sim como uma forma efetiva." (AJ2)
\end{abstract}

Para alguns entrevistados a instituição poderia atuar mais na prevenção como forma de promover os direitos humanos, além da proteção depois da violência ocorrida.

"Existe uma esfera protetiva do trabalho, existe, só que atuamos muito no pós, no que aconteceu. O que nós temos insistido muito é de que forma podemos atuar de uma forma mais preventiva da violência, acho que isso põe em questão direitos humanos de outra forma e poder falar disso em outros espaços, poder trazer a população para poder pensar junto." (E13)

\footnotetext{
${ }^{172}$ Ver capítulo 1 sobre vítimas de violência.
} 


\begin{abstract}
"Acho que sim e acho que poderia promover mais. Acho que sim, no sentido de que as pessoas chegam no CRAVI e tem contato com mais recursos, com acesso à justiça. Todo mundo pode ir lá ao fórum e procurar o seu promotor, o promotor que acompanha o seu caso e conversar com o promotor, a minoria das pessoas sabe que podem fazer isso e tem medo de procurar promotor e de falar com o promotor. Então aqui no CRAVI a gente vai trabalhando essa questão do direito mesmo com essas pessoas, eu acho que nesse sentido a informação é a principal ferramenta na garantia de direitos e na garantia dos direitos humanos. Então nesse sentido o CRAVI cumpre o papel, mas acho que poderíamos fazer mais, quando eu digo que é importante que tenham profissionais que encarem trabalhar com a violência, com o luto, porque a maioria das pessoas não quer ter contato, mas por outro lado é pouco, porque é meio frustrante você perceber que só está trabalhando porque aconteceu uma desgraça, o ideal é que não acontecesse a desgraça. Nesse sentido eu acho que o trabalho de prevenção que o CRAVI faz, é pequeno, entendo que o CRAVI é o Centro de Referência e Apoio à vítima, então ela chega aqui quando já aconteceu, mas existe um trabalho de prevenção de revitimização que nós podemos fazer, existe um trabalho de informação e orientação que pode ser um trabalho de rede que o CRAVI pode fazer e que a vítima não chegue aqui. Então no que diz respeito à política de direitos humanos eu acho que ainda falta muito trabalho de informação, principalmente junto às escolas, junto às comunidades, então nesse sentido eu acho que é pouco ainda. Não só o que o CRAVI faz, porque não é responsabilidade do CRAVI sozinho, mas é pouco o que o CRAVI faz o que está proposto na Política Nacional dos Direitos Humanos de um modo geral e de todas as instituições que trabalham com direitos humanos, (...) não devia ter CRAVI, as pessoas morrem, todo mundo morre, mas não precisa assassinar meia dúzia em cada esquina, não é assim. Acho que só com trabalho de prevenção, orientação, educação que você consegue isso." (E9)
\end{abstract}

A explicitação dos direitos humanos consagrados em legislações e tratados é considerada importante para a equipe consultada, seja pela informação sobre os direitos, seja para ampliar noção popularmente conhecida de direitos humanos e divulgar os direitos sociais. Entretanto, não há consenso se isso se ocorre nos atendimentos ou em outras ocasiões como no grupo de cidadania e discussões da equipe.

\footnotetext{
"Eu acho imprescindível porque não adianta para uma pessoa ter acesso a uma coisa que ela não sabe o que é, não sabe porque ela tem acesso, não faz sentido." (E9)

"Eu não consigo afirmar isso dos outros técnicos, mas eu acredito que o jurídico não faça isso, não fala especialmente dos direitos humanos, fala sim da legislação em que está inserido o caso: "Você tem direito segundo o Código Penal... código de prcesso penal, na Constituição Federal está isso..." Mas não é explicitado no trabalho os direitos humanos, a não ser quando a gente sai por ai para falar sobre o CRAVI, ai sim cada técnico coloca que é um trabalho e tal, mas com o usuário especificamente eu acho que não. ” (AJ1)
}

"Não sei, acho que é uma boa pergunta. (...) acho que sim, mas não no sentido educativo tipo tem um tratado ou coisa assim. Eu estou lembrando aqui de muitas vezes eu ter falado do CRAVI como um programa de direitos humanos, mas não tanto como eu gostaria (...) Então respondendo mais claramente a sua pergunta, eu acho que talvez seja insipiente ainda isso, talvez indiretamente pelos nossos atos e nossas intervenções, por exemplo, mas talvez muito mais pelo viés da democracia no sentido do usuário poder decidir também que atendimento vai receber, o que ele quer. Então tem sim, mas talvez não tão claramente para os usuários. " (E12)

"Não, no atendimento do dia-a-dia não, acho que seria até um tema interessante para educação em direitos, (...) eu acho que no CRAVI, no atendimento 
individual é meio dificil, é até complicado a gente abordar esse tema, explicar os direitos humanos, essa concepção de que direitos humanos são só de réus, dos bandidos, então acho que seria mais assunto para uma palestra mesmo, na educação em direitos. (AJ2)

"O tempo todo, acho que a gente está trazendo acaloradamente essa discussão agora quando a gente pára para pensar essa prática e vê um recorte com cidadania, essa discussão está permeada o tempo todo, tanto nos atendimentos como nas discussões em equipe, nas discussões de caso, obrigatoriamente está passando por essas discussões." (E13)

[sobre explicitação dos direitos humanos durante os atendimentos] "Depende do momento. isso entra como parte do interventivo porque você falar há lei, ou há tratado internacional, ou os direitos humanos propõem que, tudo isso, pela fala do técnico vai se articular na escuta desse usuário com o que ele está esperando, com o que ele quer, com o que ele entende, com o que ele tem de possibilidade de atendimento, (...) então ela vai entrar onde ela couber e onde ela for realizar um efeito de promoção dos direitos humanos; às vezes pode falar no texto dos direitos humanos e usar uma forma nazista ou de opressão, ou mesmo de exclusão ou de humilhação do outro, você pode usar um texto de direitos humanos e fazer exatamente isso, vai muito de como o lastro social se estrutura por uma sociedade democrática fundamentada nos direitos, então é isso que a gente tenta fazer na atuação, pelo menos é isso que é tentado, não sei se a gente consegue fazer isso sempre, é difícil." (E11)

Durante os atendimentos, é explicitado que a pessoa sofreu uma violação de direitos e que a instituição trabalha na perspectiva de direitos humanos - para os técnicos, isso pode auxiliar na informação e garantia de direitos.

"O trabalho que a gente faz mesmo é dizer que está em um lugar que se chama Centro de Referência e Apoio à Vitima: "A gente atende pessoas que passaram por violações de direitos e a gente entende que o que você passou foi uma violação de direitos. Você tinha direito a alguma coisa e esse seu direito foi violado." Isso é informar a pessoa da pertinência do CRAVI, do recorte do CRAVI, da nossa missão, do porquê a gente existe. Se a pessoa não sabe a primeira coisa que ela precisa saber é isso, no meu ponto de vista, e acho que a gente tem tentado construir isso aqui no CRAVI, porque se não for isso que ela quer, se ela acha que não sofreu uma violação, não vai ter trabalho possível aqui com ela, (...) mas quando a gente vê que isso é informado e que a pessoa por mais dificil que seja quer aderir ao atendimento, ela acha que de alguma forma isso que a gente falou faz sentido as coisas ficam muito mais fáceis de caminhar. De alguma forma a gente também dá um lugar para essa pessoa, mesmo que seja um lugar muito ruim porque de alguém que sofreu uma violação de direito, mas por outro lado tem um lugar reconhecido. Você sofreu uma violação de direito e não como em outros lugares que essa pessoa vai ser culpabilizada, penalizada, vai ser mandada embora, enfim.” (E14)

"Tem casos, por exemplo, que a pessoa não entende que o que aconteceu com ela foi uma violência, é claro que é avaliado em cada caso, mas eu acredito que a gente tem que dizer, como uma instituição de direitos humanos, de cidadania, de acesso à justiça, de a gente dizer que "isso que aconteceu com você foi uma violência" e é complicado principalmente para a psicologia afirmar que o que aconteceu com o outro foi tal coisa, mas como instituição eu acho que a gente tem que falar, avaliando o momento do caso, se a pessoa vai ter condições de escutar, de lidar com isso, mas tem que ter uma diretriz." (E12)

Porém, os direitos humanos ainda representam desafios, especialmente em relação à coerência entre o discurso e a prática dos direitos humanos. 


\begin{abstract}
"Acho que tem os dois lados em relação a isso, acho que o trabalho que a gente se propõe a fazer é, mas como não faço uma visão que dê para descolar, eu não consigo entender como o CRAVI que vai trabalhar com a defesa e proteção dos direitos ser uma instituição tão frágil e que é tão incompetente com os direitos dos seus próprios funcionários, que resvala sim para a população (...) Foi dito também que a gente não poderia mais levar os casos para a Comissão Interamericana, que a gente não estava autorizada a fazer isso. Então é uma visão que às vezes não me dá muita perspectiva de que a gente está indo na linha mesmo de quebrar o silêncio e de proteger os direitos humanos, parece que muitas vezes a gente vai reforçando isso, essas violações, e esse eu acho que é o maior perigo disso acontecer, você está em um lugar muito privilegiado de fazer isso acontecer, de fazer as pessoas se calarem, as pessoas estão aqui, dependendo da direção... (...) Às vezes a gente diz, só que quando alguém lá de cima precisa bancar, não banca e aí você fica com as pernas cortadas (...) Não vai poder mais falar aqui dentro de crimes de policiais porque são agentes do Estado? então que noção que se tem do que é violência nessa Secretaria? para mim nenhuma, porque é só olhar os dados que vai ver." (E14)
\end{abstract}

É curioso que boa parte dos entrevistados ${ }^{173}$, convidados a relatar um caso exemplar, não conseguiu narrar um caso considerado emblemático. Alguns apontaram questões éticas que impediriam o relato; outros não conseguiram destacar um caso exemplar (seja pelas peculiaridades de cada caso, seja pela ausência de um caso que representasse o CRAVI); houve quem, por não realizar atendimentos, remetesse aos técnicos essa tarefa.

Mesmo sem descrever um caso, apesar das particularidades de cada caso, algumas características comuns foram ressaltadas: a paralisação e a apatia das pessoas em razão da perda e da morte violenta, e o trabalho desenvolvido que leva tempo; as várias violências (algumas que se reproduzem por gerações) além da violência fatal; nenhuma condenação criminal e processos em curso ou inquéritos arquivados por falta de provas; o mau funcionamento do Estado e uma irresponsabilidade da sociedade civil que quase incentiva a violência. Parece não haver resultado positivo a ser comemorado, apenas falhas e faltas a serem lamentadas.

Os casos exitosos comentados pela equipe se referem a resultados verificados após a intervenção realizada no CRAVI, mas se expressam de forma individualizada.

São casos que indicam um acolhimento realizado e o usuário comprometido com o encaminhamento feito; uma orientação jurídica atenciosa e cuidadosa; mudança de postura da vítima após o trabalho desenvolvido no CRAVI, revelando exercício e reivindicação dos direitos, ou uma mobilização social sobre a questão da violência; atuação do advogado

\footnotetext{
${ }^{173}$ Interessante notar que metade dos entrevistados não conseguiu relatar um caso exemplar; dentre a outra metade que descreveu um caso, um só conseguiu comentar um caso depois de muito pensar, outro relatou dois casos.
} 
na tentativa de responder uma dúvida sobre laudo pericial e as conseqüências devastadoras do homicídio na vida dos familiares da vítima direta.

A mãe que perdeu o filho adolescente, desaparecido e encontrado morto em posição constrangedora, e as conseqüências dessa violência: a insistência numa resposta sobre o que teria acontecido e eventual abuso sofrido pelo filho, a busca feita pelo advogado por informações nos laudos e documentos do inquérito policial e do IML, a necessidade do técnico não se identificar com o usuário e querer dar respostas às angustias, e ter clareza de que na verdade nada disso "daria conta" diante do sofrimento provocado por essa morte violenta, que fez essa mãe repensar sua vida e afetou toda a família.

A mobilização e resiliência de uma mulher que teve seu irmão, egresso do sistema penitenciário, desaparecido durante a onda de violência (denominada "crimes de maio") ocorrida em maio de 2006, apesar de até o momento o corpo não ter sido encontrado. O atendimento realizado cuidadosamente com orientação jurídica e escuta atenciosa para encaminhamento de questões para as outras áreas.

Outro caso exemplar apresentado retrata o fortalecimento de uma mulher que teve dois irmãos assassinados em momentos diferentes e que mal conseguia falar sobre essas mortes e que não sabia por onde ir e se posicionava socialmente como uma criança, apesar dos seus 50 anos. No decorrer dos atendimentos e a partir da informação de que ela tinha direitos, emergiu sua história de vida marcada por situações de violação de direitos e de submissão e, na medida em que seus direitos foram esclarecidos e as possibilidades apresentadas, ela conquistou outros espaços e posições sociais, passando de uma posição de submissão a uma postura de reivindicar seus direitos e até mesmo multiplicar essas informações.

$\mathrm{O}$ acolhimento de uma mulher que teve seu marido assassinado e buscou o atendimento no CRAVI depois de 10 anos dessa morte também foi apontado como exemplar. A busca espontânea pela instituição, encontrada em guia de serviços; o desespero e falta de suporte diante da ausência do marido no momento da adolescência dos filhos, as conseqüências da morte violenta, mesmo após tantos anos "levando a vida", os encaminhamentos realizados após o acolhimento e a continuidade do acompanhamento do caso foram destacados.

Os casos mencionados foram considerados exemplares para a psicologia, para o serviço social e para o jurídico; mas os relatos sugerem atuações dos profissionais isoladamente - ainda que outros técnicos estivessem presente nos casos. É curioso que 
apesar dos esforços e da atuação integrada entre as áreas de atuação, os casos emblemáticos relatados não indicaram esse viés, nem mesmo impasses ou articulações necessárias. Apesar das reuniões semanais de discussão de casos e do investimento na troca entre os saberes e os técnicos, foi difícil comentar sobre um caso emblemático do CRAVI.

\begin{abstract}
"A gente acolhe esse caso e depois eles se perdem dentro da instituição, a gente não sabe o que aconteceu, para onde foi, se houve punição, tudo, a gente não fica sabendo de mais nada, às vezes quando ele ainda está em atendimento psi aqui a gente fica sabendo de alguma coisa, porque os casos que vem para discussão também são os casos mais emblemáticos, vem e a gente acaba sabendo de alguma coisa, mas dificilmente a gente tem respostas. Ou então quando acontece algum caso em que a usuária faleceu, ai vem, mas a gente não tem muitas noticias do que se passa com os casos. (...) Quando vem alguma resposta que vem para a equipe, é do jeito que eu estou te falando, quando acontece alguma coisa que o outro profissional tem dificuldade ou o próprio usuário, aí vem. Então pode dar uma idéia de que está tudo bem, porque se não está vindo é porque está tudo bem." (E10)
\end{abstract}

Uma hipótese para essa sensação de que os "casos se perdem dentro da instituição" seria exatamente derivada da descontinuidade do trabalho que impede a criação de uma memória institucional, além de expressar muito claramente a necessidade de se tratar o atendimento à vítima de violência fora dos marcos gerais do atendimento público que prioriza quantidade quando aqui se trata de um acompanhamento continuado de casos, com enfoque qualitativo que permitiria um começo, um meio e fim de caso avaliado e estudado. Pois a falta de informação sobre o desfecho dos casos não significa, necessariamente, que está tudo bem. A ausência da vítima não reflete uma situação livre de violência ou de violação de direitos humanos. 


\title{
Parte III
}

\section{CONSIDERAÇÕES FINAIS: O DESAFIO DA CONSOLIDAÇÃO DE UMA POLÍTICA DE ATENDIMENTO A VÍTIMAS DE VIOLÊNCIA}

\author{
"Na minha opinião só existe uma forma de enfrentar a violência, é \\ admitindo que ela existe, você não enfrenta nada que é invisivel, \\ então admita a existência e a partir dai pode se fazer um trabalho \\ nesse sentido." (E9)
}

A vítima de violência ainda é invisível, apesar dos investimentos, público e privado, para seu atendimento no Brasil. É certo que tem aumentado a discussão sobre as vítimas, seus direitos e sua participação em procedimento judicial; entretanto, esse tema ainda é bastante periférico no debate sobre violência e também sobre direitos humanos.

Há programas federais, estaduais e até municipais de atendimento a vítimas de violência, entretanto, pouco se sabe sobre o perfil dessas pessoas, as principais demandas e o exercício dos direitos após a violação. O desamparo é constante. Perpetrada a violência, parece não se enxergar mais a vítima. O Estado e a sociedade, quando muito, costumam buscar justiça e punição do agressor. Há apenas a violência, o autor da violência e a necessidade de punição. A vítima desaparece, ainda que existam algumas iniciativas de apoio e atenção às vítimas de violência.

\section{Políticas Federais de atendimento às vítimas de violência}

$\mathrm{Na}$ esfera federal, o apoio a centros de atendimento a vítimas de violência sexual é realizado principalmente por meio do Programa Sentinela, visando a implementação do eixo estratégico do atendimento previsto no Plano Nacional de Enfrentamento da Violência Sexual Infanto-Juvenil ${ }^{174}$, na perspectiva de efetuar e garantir o atendimento especializado, e em rede, às crianças e adolescentes em situação de violência sexual e às famílias.

O Programa Sentinela, no âmbito da assistência social, foi criado em 2002 como resposta a uma proposta de atendimento especializado, multiprofissional e interdisciplinar,

\footnotetext{
${ }^{174}$ O Plano Nacional de Enfrentamento da Violência Sexual Infanto-Juvenil, apresentado e deliberado pelo Conselho Nacional dos Direitos da Criança e do Adolescente (CONANDA) em 2000, estabelece um conjunto de diretrizes para o enfrentamento do abuso e exploração sexual com base em seis eixos estratégicos: análise da situação, mobilização e articulação, defesa e responsabilização, atendimento, prevenção e protagonismo juvenil. Não se pretende, nessa dissertação, aprofundar a discussão sobre a política nacional de enfrentamento da violência sexual e doméstica - motivo pelo qual serão apenas comentados os principais aspectos da política, especialmente sob o enfoque do atendimento.
} 
numa perspectiva de construção de redes, a partir das crianças, adolescentes e famílias envolvidas em situação ou risco de violência sexual. É um "conjunto de ações sociais especializadas e multiprofissionais dirigidas ao atendimento de crianças, adolescentes e famílias envolvidas com a violência sexual", sob responsabilidade do Ministério do Desenvolvimento Social e Combate à Fome (MDS), inserido no Programa de Combate ao Abuso e Exploração Sexual de Crianças e Adolescentes, coordenado pela Secretaria Especial dos Direitos Humanos da Presidência da República (SEDH/PR) ${ }^{175}$.

O Programa Sentinela tem como objetivo ${ }^{176}$ contribuir para a promoção, defesa e garantia de direitos de crianças e adolescentes vítimas de violência sexual, buscando:

- identificar o fenômeno e riscos decorrentes;

- prevenir o agravamento da situação;

- promover a interrupção do ciclo de violência;

- contribuir para a devida responsabilização dos autores da agressão ou exploração; $e$

- favorecer a superação da situação de violação de direitos, a reparação da violência vivida, o fortalecimento dos vínculos familiares e comunitários, a potencialização da autonomia e o resgate da dignidade

O programa é operacionalizado no âmbito dos Centros de Referência Especializado de Assistência Social (CREAS), de abrangência local ou regional, base, conforme Normas Operacionais Básicas da Política Pública de Assistência Social (NOB/SUAS). São prestados atendimentos especializados de acolhimento e proteção imediata com abordagem multiprofissional para apoio psicosocial e jurídico e é feita a oferta de retaguarda, em

\footnotetext{
${ }^{175}$ A SEDH/PR, por meio da Subsecretaria de Promoção dos Direitos da Criança e do Adolescente (SPDCA) coordena o Programa Nacional de Combate ao Abuso e Exploração Sexual de Crianças e Adolescentes e tem priorizado o enfrentamento à exploração sexual comercial, incluindo o tráfico de crianças e adolescentes, para fins de exploração sexual. As ações incluem a coordenação de uma Comissão Intersetorial de Enfrentamento da Violência Sexual contra Crianças e Adolescentes, coordenação e execução de Disque Denúncia Nacional de Abuso e Exploração Sexual contra Crianças e Adolescentes (Disque Denúncia Nacional - 100), Programa de Ações Integradas e Referenciais de Enfrentamento da Violência Sexual Infanto-Juvenil no Território Brasileiro - PAIR e Política Nacional de Enfrentamento ao Tráfico de Pessoas. A Comissão Intersetorial de Enfrentamento da Violência Sexual contra Crianças e Adolescentes é uma estratégia do governo federal para a construção de uma política integrada, articulando, informando, sugerindo e apoiando ações. É composta por membros do Poder Executivo, Legislativo, Judiciário, Ministério Público, CONANDA, Comitê Nacional de Enfrentamento, organismos internacionais e organizações da sociedade civil voltadas ao enfrentamento do problema. Essa comissão tem reuniões mensais e é coordenada, desde 2005, pela SEDH/PR. De acordo com: http://www.presidencia.gov.br/estrutura_presidencia/sedh/spdca/exploracao_sexual/Acoes_PPCAM/com_in tersetorial/ (acesso em 24/01/09).

176 De acordo com: http://www.mds.gov.br/suas/guia_creas/media-complexidade/servicos-deenfrenatemento-as-criancas-e-aos-adolescentes-vitimas-de-violencia-abuso-e-exploracao-sexual-e-a-suasfamilias/servicos-de-enfretamento.doc/html2pdf (acesso em 24/01/09)
} 
articulação e interação com o Sistema de Garantia de Direitos e a Rede de Proteção Social, em caráter de prosseguimento sistemático individual, familiar e comunitário. ${ }^{177}$

De acordo com a Secretaria Nacional de Assistência Social ${ }^{178}$, esse serviço deve proporcionar atendimento psicossocial e jurídico que considerem: o compromisso fundamental de proteção à criança e ao adolescente; a necessidade de identificar o fenômeno e avaliar riscos; a compreensão da família em sua dinâmica interna e externa;e a necessidade de atenções específicas de caráter social, psicológico e jurídico a crianças, adolescentes e famílias. Deve-se buscar, no processo de composição e articulação da rede local, alternativas para o atendimento e acompanhamento dos autores de agressão sexual contra crianças e adolescentes. Além do atendimento psicossocial e jurídico, o serviço deve ofertar ações de prevenção e busca ativa que realize o mapeamento das situações de risco e/ou violação de direitos que envolvam crianças e adolescentes. Tais equipes devem realizar ações educativas, orientações e encaminhamento ao Conselho Tutelar, à rede de serviços socioassistenciais e a outros serviços existentes na localidade.

Constatadas situações de violência ou exploração de crianças e adolescentes, a autoridade competente deve ser comunicada, sem prejuízo da notificação ao Conselho Tutelar. Para o efetivo trabalho pela garantia de direitos, o serviço deve manter, ainda, articulação com: i. as organizações que atuam junto à Defesa de Direitos de crianças, adolescentes e famílias em situação de violência e junto à Responsabilização dos autores de violência sexual; e ii. com a Defensoria Pública e serviços de assistência jurídica gratuita da $\mathrm{OAB}$ e das Universidades, dentre outras que se mostrarem relevantes. ${ }^{179}$

No município de São Paulo, o Programa Sentinela é executado pela Secretaria Municipal de Assistência e Desenvolvimento Social (SMADS). Em 2007 foi criada uma Comissão Municipal de Enfrentamento à Violência, Abuso e Exploração contra Crianças e Adolescentes, composta por representantes da SMADS, Conselho Municipal de Assistência Social (Comas), Conselho Municipal dos Direitos da Criança e do Adolescente (CMDCA), Conselho Municipal de Políticas Públicas de Drogas e Álcool (Comuda), Comissão Municipal de Direitos Humanos (CMDH), Conselhos Tutelares, outras secretarias municipais, universidades e organizações da sociedade civil.

\footnotetext{
${ }^{177}$ De acordo com Plano Nacional de Enfrentamento da Violência Sexual Infanto-Juvenil: uma política em movimento - Relatório de Monitoramento 2003-2004, Brasília, 2006, p. 12-14.

178 Ver: http://www.mds.gov.br/suas/guia_creas/media-complexidade/servicos-de-enfrenatemento-ascriancas-e-aos-adolescentes-vitimas-de-violencia-abuso-e-exploracao-sexual-e-a-suas-familias/servicos-deenfretamento.doc/download (acesso em 24/01/09)

${ }^{179}$ Pelo que se depreende, o atendimento jurídico deve ser prioritariamente realizado por meio da articulação da rede, em parceria com Centros de Defesa da Criança e do Adolescente e com Defensoria Pública.
} 
Em São Paulo, o Programa Sentinela coordenado pela SMADS é operacionalizado por meio de cinco Centros de Referência ${ }^{180}$, onde são executadas ações especializadas e de proteção às crianças e adolescentes, como atendimento multiprofissional (psicólogos, assistentes sociais, educadores), apoio psicossocial, que atua na prevenção da violência doméstica, física, sexual e psicológica; além do acompanhamento permanente dos casos. $\mathrm{O}$ atendimento é realizado às vítimas e, quando possível, aos agressores.

No âmbito da política federal de apoio ao atendimento às vítimas de violência em geral, há Programas de Assistência e Proteção a Vítimas e Testemunhas - que inclui Programa de Assistência a Vítimas e a Testemunhas Ameaçadas, Centros de Atendimento a Vítimas de Crimes, Programa de Proteção de Defensores de Direitos Humanos, Programas de Proteção a Crianças e Adolescentes Ameaçados de Morte. ${ }^{181}$

Embora a preocupação do constituinte com a assistência a vítimas de crime doloso $^{182}$, não foram localizadas informações sobre os Centros de Atendimento a Vítimas de Crimes ${ }^{183}$ no site da Secretaria Especial dos Direitos Humanos - SEDH/PR ${ }^{184}$.

\footnotetext{
${ }^{180}$ Os serviços integram o "Programa São Paulo Protege suas Crianças" e os Centros de Referência atendem regionalmente cinco regiões da cidade. O CNRVV, do Instituto Sedes Sapientiae, atende as regiões norte e oeste.

${ }^{181}$ Em dezembro de 2008, houve o $7^{\circ}$ Seminário Brasileiro de Assistência e Proteção a Vítimas e a Testemunhas Ameaçadas, com a participação de representantes desses programas para debate sobre questões estratégicas comuns para a consolidação de uma Política Pública de Proteção e de Assistência. De acordo com:

http://www.presidencia.gov.br/estrutura_presidencia/sedh/noticias/ultimas_noticias/MySQLNoticia.2008-1201.5537/view?searchterm=CEAV (acesso em 24/01/09)

${ }^{182}$ Dispõe o artigo 245 da Constituição Federal: "A lei disporá sobre as hipóteses e condições em que o Poder Público dará assistência aos herdeiros e dependentes carentes de pessoas vitimadas por crime doloso, sem prejuizo da responsabilidade civil do autor do ilícito".

${ }^{183}$ De acordo com documento da Gerência de Assistência a Vítimas e a testemunhas ameaçadas, da Secretaria do Estado de Direitos Humanos/Ministério da Justiça, assinado por Nilda Turra, apresentado no Seminário "Integração das ações: um serviço às vítimas da violência", em julho de 2002, o atendimento prestado em centros de apoio a vítimas é realizado por equipe multidisciplinar formada por profissionais das áreas jurídica, psicológica e social, numa "abordagem teórica, técnica e prática do problema da violência com enfoque na promoção da cidadania e da cultura dos direitos humanos (...) de modo a que possam realizar a avaliação dos fatos vividos à luz de parâmetros legais e éticos e definir e formular suas prioridades e estratégias de ação, evitando, assim o processo de vitimização que pode conduzir ao fatalismo e imobilismo".
}

184 Em última visita ao site da Secretaria Especial de Direitos Humanos [http://www.presidencia.gov.br/estrutura_presidencia/sedh/], em 26/01/09, não foi localizada nenhuma informação sobre os Centros de Atendimento a Vítimas de Crimes. Apenas sobre a Política de Proteção a Pessoas Ameaçadas, com informações sobre o Programa de Assistência a Vítimas e a Testemunhas Ameaçadas, Programa de Proteção de Defensores de Direitos Humanos, Programas de Proteção a Crianças e Adolescentes Ameaçados de Morte. Temos informações de que há cerca de 25 Centros de Atendimento a Vítimas de Crimes - como o Centro de Referência e Apoio à Vítima (CRAVI) em São Paulo, Núcleo de Atendimento às Vítimas de Crimes Violentos - NAVCV em Minas Gerais; Comitê de Vítimas de Violência do Rio Grande do Norte, dentre outros. Não apenas a denominação dos diversos Centros de Atendimento a Vítimas de Crimes é diversa, mas cada um conta com uma metodologia, recorte e estratégias de atendimento próprios. 
Em São Paulo, a Constituição Estadual dispõe, em seu artigo 278, que "O Poder Público promoverá programas especiais, admitindo a participação de entidades não governamentais e tendo como propósito: (...) V - criação e manutenção de serviços de prevenção, orientação, recebimento e encaminhamento de denúncias referentes à violência; VI - instalação e manutenção de núcleos de atendimento especial e casas destinadas ao acolhimento provisório de crianças, adolescentes, idosos, portadores de deficiências e vítimas de violência, incluindo a criação de serviços jurídicos de apoio às vítimas, integrados a atendimento psicológico e social". Na mesma linha, Programa Estadual de Direitos Humanos (Dec. Est. n. ${ }^{\circ} 42.209 / 97$ - itens 106 e 108) ${ }^{185}$, a Lei Federal 9.807/99 e a Lei Estadual 10.354/99 dispõem sobre a criação de programas de proteção e assistência a vítimas. $^{186}$

Apesar das iniciativas federais de apoio ao atendimento a vítimas de violência, alguns desafios se impõem à consolidação de uma Política Pública de Assistência a Vítimas de Violência. Para a Coordenadora Geral de Proteção à Testemunha da Secretaria Especial de Direitos Humanos, alguns desses desafios são ${ }^{187}$ :

- Universalização do serviço com ampliação dos centros para todas as unidades da federação e expansão para os municípios onde os indices de violência sejam mais críticos;

- Articulação de políticas públicas complementares com institucionalização de parcerias com o objetivo de garantir a integralidade dos direitos das vítimas da violência e seus familiares, assegurando seu acesso a serviços públicos tais como assistência social, educação, saúde, previdência social, trabalho etc.

- Alargamento da base social do programa - possibilitar a coresponsabilização da sociedade civil organizada na formulação e na implementação da política pública, garantindo o controle social da política.

\footnotetext{
185 Programa Estadual de Direitos Humanos: “106. Criar programa estadual de proteção a vítimas e testemunhas, bem como a seus familiares, ameaçados em razão de envolvimento em inquérito policial e/ou processo judicial, em parceria com a sociedade civil. (. . .). 108. Criar programa de assistência aos herdeiros e dependentes carentes de pessoas vitimadas por crimes dolosos, nos termos do artigo 245 da Constituição Federal".

${ }^{186}$ Nesse sentido foi criado em 1998 o Centro de Referência e Apoio à Vítima, CRAVI.

${ }^{187}$ De acordo com pronunciamento da Coordenadora Geral de Proteção à Testemunha, Nilda Maria Turra Ferreira, durante o V Seminário "Construção da Cidadania: desdobramentos dos atendimentos às Vítimas de Violência", de 19 a 20 de agosto de 2005. IN: Coletânea do V Seminário "Construção da Cidadania: desdobramentos dos atendimentos às Vítimas de Violência”, p.29-31.
} 
- Comprometimento dos órgãos de segurança pública e justiça expressandose também na garantia de uma dotação orçamentária condizente com a importância e com as dimensões da política pública de assistência às vitimas da violência;

- Capacitação permanente e sistemática dos agentes atuantes no programa para que alcancemos o refinamento, a socialização e a sistematização dessas experiências como vistas ao aperfeiçoamento e qualificação do atendimento

- Criação de uma política de comunicação com divulgação de informações e esclarecimentos às autoridades e ao público em geral sobre o programa, a fim de facilitar o acesso das pessoas que dele necessitem;

- Criação de uma legislação especifica como marco de institucionalidade ${ }^{188}$.

Não obstante as políticas federais de apoio e assistência a vítimas, alguns aspectos da vitimização parecem ainda ocultos e outros desafios se impõem à consolidação de uma política de atendimento a vítimas de violência, especialmente quanto ao aspecto jurídico. Ainda que ambas políticas estejam ligadas à Secretaria Especial de Direitos Humanos, a perspectiva e abordagem de direitos humanos ainda não se mostram consistentes na prática dos centros de atendimento estudados.

\section{CNRVV e CRAVI: semelhanças e diferenças entre dois centros de referência à vítima de violência}

As experiências dos centros de referência analisados, apesar das diferenças, apresentam problemas semelhantes, o que pode contribuir para uma reflexão sobre os desafios de uma política de atendimento às vítimas de violência.

O CNRVV é uma referência no atendimento a vítimas de violência doméstica e sexual, e atende também agressores. O CRAVI é pioneiro no atendimento às vítimas indiretas da violência fatal. Ambos centros atendem vítimas de violência doméstica e sexual, no entanto, o CRAVI começou a realizar esse tipo de atendimento em 2007 e tem experiência significativa no atendimento aos familiares das vítimas diretas de homicídio e latrocínio.

\footnotetext{
${ }^{188}$ Na ocasião desse pronunciamento em 2005, a coordenadora geral informou sobre a elaboração, no âmbito da SEDH, de um Projeto de Lei que estabelece a Política Nacional de Assistência e Proteção a Vítimas e Colaboradores da Justiça, criando um Sistema Nacional de Assistência e Proteção a Vítimas e Colabores da Justiça. Entretanto, tal projeto de lei não foi localizado.
} 
Embora os centros tenham vinculação institucional e formas de financiamento diversas - o CNRVV está ligado a uma organização da sociedade civil, especificamente um centro de reflexão, formação e serviços, com financiamento público e privado; e o CRAVI ligado a uma Secretaria de Governo do Estado, com financiamento integralmente público - ambos sofrem com a descontinuidade de financiamento e linhas de atuação. Os intervalos entre convênios, a instabilidade profissional, baixa remuneração e a modificação da forma de atendimento em razão de não inclusão de determinados profissionais na equipe foram criticados pelos entrevistados dos dois centros.

A composição da equipe e as áreas de atuação também apresentam diferenças. É curioso que, embora não haja dedicação exclusiva no CNRVV (muitas das entrevistadas mencionaram atividades diárias fora do centro, em consultório particular), há uma estabilidade maior na composição da equipe do CNRVV (a maioria das entrevistadas trabalha na instituição há mais de cinco anos); ao passo que a equipe do CRAVI composta por profissionais da área da psicologia, serviço social e direito - é recente e formada apenas por funcionários públicos, que não indicaram atividades além das desempenhadas na instituição. Os profissionais do CNRVV desempenham atividades nas diversas áreas de atuação do centro (atendimento, prevenção, formação, parceria e pesquisa), enquanto os profissionais do CRAVI exercem essencialmente atendimento às vítimas e recentemente o programa tem investido em outras áreas como formação de rede $\mathrm{e}$ referência para a ampliação dos centros de atendimento. Talvez a possibilidade de exercer outras funções e atividades além do atendimento direto às vítimas de violência contribua para maior estabilidade da equipe.

Outra distinção importante se refere ao vínculo de trabalho. Enquanto os técnicos do CNRVV são contratados por projeto financiado - o que se mostra inadequado diante do caráter do serviço realizado: atendimento a vítimas de violência, o que exige uma continuidade do trabalho e vínculo entre profissional e usuário - os técnicos do CRAVI são funcionários públicos - o que também gera alguns problemas, especialmente quanto à remuneração diferenciada entre funcionários que exercem a mesma função e a inadequação do cargo em comissão para técnicos que realizam o atendimento às vítimas, sem qualquer função de "confiança" ou de caráter político que justifique a utilização de tal cargo. ${ }^{189}$ ${ }^{189}$ Mesmo a relação entre o poder público e organização da sociedade civil se mostra diversa entre os
centros. Enquanto no CNRVV o convênio com a Prefeitura de São Paulo, via SMADS, se mostra renovável
por cinco anos (o que garante certa estabilidade da equipe); no CRAVI, o convênio era firmado entre a SJDC
e ONG como algo extraordinário, com período de duração de no máximo 12 meses, sem a garantia de uma
renovação ininterrupta - o que certamente dificulta uma estabilidade da equipe de trabalho e a definição de 
O perfil das vítimas atendidas parece ser melhor compreendido pela equipe do CRAVI, a qual soube indicar minimamente as condições socioeconômicas das pessoas atendidas, ao passo que no CNRVV essas informações foram remetidas à assistente social. Durante as entrevistas nos dois centros, esse perfil foi compreendido e mencionado pelos técnicos como o recorte do serviço e as demandas recorrentes. Parece ser dada pouca relevância para a condição de vida da pessoa atendida nas duas instituições, não apenas em relação à renda, à escolaridade e à região de moradia, mas especialmente quanto à composição familiar, ao acesso à justiça e à dinâmica de violência instaurada e seu histórico. Tais informações são bastante particulares e dependem de cada caso atendido, mas poderiam ser coletadas e sistematizadas, o que possibilitaria a compreensão sobre a situação real de acesso a direitos e contribuiria para planejamento de ações de prevenção da violência e formas de intervenção durante o atendimento.

A forma de atendimento é semelhante: em ambas instituições há um procedimento de recepção no serviço, avaliação preliminar das principais demandas e encaminhamentos para diferentes formas de intervenção (interna ou externa). No CNRVV há inicialmente um plantão social e o procedimento de recepção (denominado triagem) é realizado em grupos coordenados por psicólogos e divididos conforme a idade dos envolvidos (apenas o grupo de pais é coordenado por psicólogo e assistente social). No CRAVI, essa recepção (o acolhimento) é realizada individualmente ou com o grupo familiar, sempre com profissionais da área da psicologia e do serviço social - há um esforço para que os defensores públicos também participem do acolhimento. Uma diferença importante é que apenas no CRAVI há profissionais da área jurídica, o que viabiliza o atendimento de questões relacionadas ao procedimento judicial.

As principais demandas apresentadas no CNRVV se referem a questões psicológicas; no CRAVI, embora o atendimento psicológico também seja bastante solicitado pelos usuários, a demanda jurídica é bem freqüente. Talvez por não haver profissionais da área jurídica na equipe do CNRVV, dúvidas jurídicas ou dificuldade de acesso à Justiça sequer foram mencionadas como demandas. No CRAVI, as pessoas atendidas raramente apresentam uma demanda social clara, o que exige das assistentes

metas de longo prazo. Adicione-se a isso a questão dos cargos comissionados para atendimento da vítima, tal qual os funcionários contratados pela ONG conveniada, o que poderia reforçar uma idéia de que o convênio serviria tão-só para a contratação de mais mão-de-obra. Nesse sentido, verifica-se uma precária estrutura de trabalho para o atendimento das vítimas de violência fatal no CRAVI e um investimento inadequado e insuficiente para a consolidação dessa política de atendimento às vítimas de violência no Estado de São Paulo. 
sociais um trabalho de identificação de questões sociais a serem atendidas; já no CNRVV, há uma procura quase que espontânea dos usuários pelo serviço social.

A vitimização secundária não é comentada nas entrevistas como uma demanda para o CNRVV, ao passo que para o CRAVI surge, principalmente, na fala dos profissionais da área jurídica como uma questão relevante que exige a sensibilização dos atores do sistema de justiça. As demandas do CNRVV são, em geral, ligadas à dinâmica da violência e apresentadas de forma individualizada - das vítimas nos atendimentos e da comunidade nas atividades de prevenção - com conotação pouco coletiva ou pública como as que surgiram nas entrevistas do CRAVI: direitos humanos, cidadania e acesso à Justiça.

Outra distinção importante em relação ao atendimento se refere ao caráter compulsório de muitos casos encaminhados ao CNRVV; enquanto no CRAVI o atendimento não é obrigatório e a adesão é menos complicada.

Embora a busca pelos serviços seja basicamente por meio de encaminhamentos, em ambos não há uma identificação precisa de cada um parceiros, apenas uma indicação genérica da área de atuação da fonte. O sistema de justiça é a principal fonte de encaminhamento nos dois centros; principalmente o Poder Judiciário no caso do CNRVV; já no CRAVI há maior diversidade entre promotores, delegados de polícia e funcionários do IML. Entretanto, a indicação para atendimento no CRAVI é feita geralmente por alguém da rede (alguns promotores, alguns delegados), mas não de forma institucionalizada. No CNRVV, provavelmente em razão do caráter compulsório dos atendimentos, a fonte de encaminhamento é notificada sobre o início do atendimento e também em caso de desligamento. Em ambas instituições, os equipamentos da área da saúde e da educação foram raramente mencionados.

A troca entre os técnicos da equipe parece ser mais estimulada no CRAVI, onde as reuniões semanais e atividades em equipe - como a sistematização da metodologia de atendimento - favorecem maior integração entre as áreas, embora a área jurídica esteja mais afastada e tenha pouca interação com as demais. O acolhimento no CRAVI é realizado por profissionais da área da psicologia e serviço social (e pretende-se que a área jurídica também participe) e há a proposta do grupo de cidadania, que pode ser coordenado por profissionais de qualquer das áreas. Por outro lado, no CNRVV a triagem é coordenada basicamente por psicólogos e as assistentes sociais participam apenas do grupo de pais e responsáveis. 
A conversa entre os técnicos sobre os casos atendidos - que acontece muitas vezes nos corredores do CNRVV, talvez pela insuficiência do espaço de troca entre os técnicos na instituição ${ }^{190}$ - é incentivada no CRAVI e a discussão somente entre os técnicos envolvidos no caso é evitada, privilegiando-se a reunião de equipe ${ }^{191}$. No CRAVI, além da reunião de equipe, há reunião das áreas de atendimento (psicologia e serviço social; o jurídico composto por defensores públicos não faz essa reunião de área).

Entretanto, a relação com a rede de entidades parceiras parece ser mais articulada no CNRVV - seja em relação aos encaminhamentos necessários nos casos em atendimento $^{192}$, seja quanto às organizações que participam do fórum e outras atividades de prevenção da violência. Nas entrevistas dos técnicos do CRAVI é mencionado o investimento para fomentar o contato com as entidades, mas não parece haver discussão ou troca sobre os casos atendidos com outras organizações parceiras.

As parcerias no CNRVV são buscadas e fomentadas, principalmente, com vistas a captar recursos para financiamento de projetos e manutenção da equipe, mas também para melhor encaminhamento em relação aos casos atendidos; no CRAVI, a equipe de rede concentra as atividades na participação de eventos, em algumas ocasiões para sensibilização sobre violência e vitimização.

Nos dois centros de atendimento a vítimas, há uma queixa recorrente em relação à falta de supervisão institucional, mesmo que reconhecidamente importante para o cuidado com os técnicos e para a qualidade do serviço prestado. No CNRVV há uma supervisão mensal com um profissional externo, mas essa periodicidade se mostra insuficiente diante da necessidade de discussão, reflexão e apoio da equipe. No CRAVI a equipe não tem supervisão há cerca de um ano, mas a entidade tem investido em alguns espaços para troca e apoio à equipe, como reuniões semanais, participação em eventos e oficinas de capacitação.

\footnotetext{
190 “antes era só zona oeste e já tinha essa reunião, agora a gente pegou zona norte e continua só essa reunião. Então os casos são muitos e quando não dá conta da gente discutir em equipe o que acontece muito são as discussões paralelas" (E4)

191 “A gente faz [discussão de caso] no dia-a-dia às vezes, mas a gente tem feito uma escolha de não, a não ser que seja urgente ou que a pessoa esteja muito angustiada, tirar um tempinho e conversar, mas de apostar mesmo no dispositivo que a gente já tem e não ir criando outros subgrupos, porque se a gente conversar em subgrupo, a equipe não vai se beneficiar disso, e a dupla ou o trio não vai se beneficiar da opinião da equipe. Então a gente tem mesmo deixado cada vez mais esses subgrupos, minigrupos, para investir na equipe, evitar um pouco e apostar no momento em que está a equipe toda" (E12)

192 Embora a troca entre os técnicos do CNRVV não tenha se mostrado como uma preocupação da instituição, a discussão com entidades parceiras sobre os casos em atendimento - por meio de reuniões ou troca de relatórios - surgiu com mais ênfase nas entrevistas do CNRVV, em comparação aos entrevistados do CRAVI.
} 
A relevância da troca entre os profissionais foi afirmada nas entrevistas dos dois centros. A falta de integração entre a área jurídica e as demais foi constantemente mencionada pelos técnicos do CRAVI - ainda assim, o diálogo entre os profissionais das áreas de psicologia e serviço social aparece, no discurso dos técnicos entrevistados, de maneira cotidianamente construída pela equipe. Já no CNRVV, a troca entre os psicólogos e assistentes sociais surge como necessidade do trabalho desenvolvido, mas não como um investimento institucional.

A equipe do CNRVV considera o atendimento multidisciplinar, às vezes inter, mas com a transdisciplinaridade como ideal. Os entrevistados do CRAVI, por outro lado, consideram o atendimento multidisciplinar em relação ao jurídico, mas com proposta de ser interdisciplinar. É interessante que a relação com os serviços da rede se mostra mais estimulada na experiência do CNRVV, ao passo que no CRAVI a troca entre os técnicos se apresenta mais cotidiana e de certa forma provocada pela própria instituição.

Quanto às dificuldades apresentadas nos dois centros de referência, alguns problemas são muito semelhantes, mesmo tratando-se de um programa público-estatal e um projeto da sociedade civil. As condições de trabalho, as dificuldades inerentes ao tema da vítima de violência e as implicações desse trabalho foram criticados pelos técnicos de ambas entidades, com algumas distinções. A remuneração e a descontinuidade do serviço e do financiamento foram apontadas pelos entrevistados dos dois centros.

A composição da equipe - determinada pelo financiamento e previsão de convênio, no caso do CNRVV, ou pela determinação política de parceria com a Defensoria Pública no CRAVI - também foi uma dificuldade comum aos centros. A impotência diante da gravidade da situação enfrentada e a adesão aos atendimentos foram mencionadas pelos técnicos dos dois centros. Para quase todos os entrevistados, o trabalho de atendimento às vítimas de violência é, em si, um desafio. Lidar com o tema cotidianamente, fazer a intervenção e conseguir observar eventual resultado é desafiador. A carência de cuidado e suporte aos técnicos (especialmente a supervisão institucional) foram problemas recorrentes nas entrevistas dos dois centros.

Uma dificuldade apontada apenas pela equipe do CRAVI se refere aos casos que envolvem agentes públicos. A violência estatal representa uma dificuldade para uma instituição pública como o CRAVI - seja pela ambigüidade da atuação do Estado que pratica a violência e que oferece um apoio a suas vítimas, seja pela delicada parceria entre Secretarias de Estado do mesmo governo (SJDC e SSP), seja pela sensação de impunidade 
comentada pelos familiares, seja pela necessidade de maior articulação com outros órgãos governamentais e não-governamentais nesses casos (especialmente com Corregedorias e Ouvidoria da Polícia).

A relação do centro com outras entidades da rede foi uma dificuldade apontada pelos técnicos do CNRVV e do CRAVI, mas com algumas diferenças. Em relação ao primeiro, o maior entrave se refere à falta ou inexistência de serviços disponíveis na rede de atendimento, em especial para encaminhamentos jurídicos. Quanto ao segundo, o próprio contexto social (não tanto a rede de serviços) e a difícil construção de parcerias (com a sociedade civil e com o próprio governo) foram as dificuldades mais recorrentes.

A principal diferença entre as dificuldades mencionadas nas entrevistas se refere à fragilidade institucional e autonomia do CRAVI. Talvez por se tratar de um programa estatal, suas diretrizes sejam mais suscetíveis a determinações políticas nem sempre condizentes aos propósitos do atendimento realizado. O compromisso e a responsabilidade da equipe, em especial da coordenação, foram problematizados: questões políticas não deveriam se sobrepor em detrimento da qualidade do atendimento prestado e da responsabilidade com a missão institucional e com o atendimento às vítimas de violência.

Os dois centros de referência são vinculados a um instituto ou secretaria - o CNRVV ao Instituto Sedes Sapientiae e o CRAVI à Secretaria da Justiça e da Defesa da Cidadania - mas a qualidade dessa ligação é diversa em cada centro. Enquanto o CNRVV parece ter um bom entrosamento com o Instituto Sedes, o que garante certa estabilidade para a equipe; o mesmo não ocorre entre o CRAVI e a SJDC.

\begin{abstract}
"Eu acho que uma das coisas que pra gente conta muito é ter um entrosamento dentro do próprio instituto com as outras áreas com os outros setores numa convivência muito construída, o que de certa forma garantiu que a gente pudesse ter um clima de trabalho favorável, então isso ajudou bastante (...) essa quase que integração interna aqui também faz parte para garantir que você tenha energias para fazer um trabalho de atendimento e que é bom, então eu vejo como quase que 30\% assim de estabilidade pra equipe é ter uma boa relação interna com o instituto." (E7)

"não é fácil não, a ponte da Secretaria com o CRAVI, (...) então é sempre uma luta, e isso vai desgastando, vai desgastando tanto a coordenação e vai desgastando também a equipe (...) é difícil." (E15)
\end{abstract}

Esse desgaste agrava um problema em relação à própria autonomia do CRAVI, o que não ocorre com o CNRVV.

As dificuldades mencionadas pela equipe do CNRVV podem ser sintetizadas em questões relativas à violência doméstica e sexual e ao trabalho de atendimento às vítimas, com destaque para questões jurídicas. Por outro lado, a fragilidade institucional do CRAVI abrange e implica em boa parte das dificuldades indicadas pelos técnicos entrevistados. 
Embora ambos centros prestem atendimento a vítimas de violência, o conceito de vítima é um pouco diverso para os técnicos. A noção de passividade é comum, mas para os entrevistados do CNRVV, a idéia de estado ou situação de vítima indica uma desproteção; ao passo que para os técnicos do CRAVI, há uma perspectiva de sujeito de direito e a vítima, que pode ser direta ou indireta, teve um direito violado. Nas entrevistas do CRAVI, emergiu a questão da dificuldade de identificação da própria pessoa atendida no centro como vítima; enquanto para a equipe do CNRVV, a relação do agressor e a dinâmica de violência foram mais comentadas.

Lidar com vítimas de violência é desafiador para todos, seja pela mobilização interna provocada, seja pela necessidade de constante reflexão sobre a prática, seja pela estrutura emocional exigida do técnico. Nesse contexto, o cuidado com a equipe técnica é fundamental. E nos dois centros há a mesma falha: apesar da reconhecida relevância do espaço de supervisão institucional, isso não é devidamente oferecido aos cuidadores. $\mathrm{O}$ suporte se reduz a reuniões semanais de equipe para discussão de casos e o técnico deve, individualmente, buscar esse cuidado maior em terapia externa. A maioria dos entrevistados faz terapia e encontra suas "válvulas de escape" individualmente. No CRAVI, muitos profissionais adoeceram.

$\mathrm{O}$ atendimento no CNRVV parece ter como eixo de evitar que a vítima se torne um agressor e, assim, romper o ciclo de violência. No CRAVI, a noção de direitos é mais presente e o atendimento é mencionado como uma forma de contribuir para o acesso à justiça e exercício de direitos. A violência fatal, diversamente da violência doméstica e sexual, tem pouca mobilização social ${ }^{193}$ e discussão acumulada - o que parece representar um desafio maior para o CRAVI.

Uma diferença marcante entre as instituições se refere ao papel do direito no atendimento às vítimas. Apenas no CRAVI há uma área jurídica que presta orientação aos usuários, além de acompanhar o andamento do inquérito policial ou processo judicial e prestar informações e consulta aos demais técnicos. A relevância do atendimento jurídico é unânime entre os entrevistados do CRAVI e há uma queixa recorrente ao formato da

\footnotetext{
${ }^{193}$ A mobilização social diante do homicídio e morte violenta é diferente da mobilização diante da violência doméstica e sexual. Os familiares da vítima de homicídio não são compreendidos como vítima e tem escassos pontos de apoio. Por mais complexa que seja a violência doméstica e sexual, já há uma "bagagem teórica" e o debate sobre esse tema é mais disseminado que em relação à violência fatal, que se expressa quase que somente em números e estatísticas de mortes na população. A própria sociedade civil e o governo pouco debatem sobre essa temática, o que favorece o isolamento das vítimas indiretas e dificulta o trabalho desenvolvido no CRAVI.
} 
parceria com a Defensoria Pública na equipe jurídica, composta basicamente por defensores públicos, que prestam atendimento jurídico, em regime de plantão.

Para os profissionais da área jurídica, lidar com a vítima de violência e a integração com as outras áreas representam os maiores desafios ao trabalho jurídico, como se verifica em AJ1 ${ }^{194}$ sobre a dificuldade de participar do acolhimento - procedimento de recepção da vítima na instituição e espaço interdisciplinar por excelência. A formação jurídica não favorece a troca com outros profissionais, nem mesmo com profissionais da mesma formação. Os encaminhamentos realizados para assistência judiciária na Defensoria Regional não são acompanhados e há uma queixa do próprio defensor sobre a dificuldade de se obter informações sobre o procedimento instaurado com outros colegas, como se depreende de $\mathrm{AJ} 2^{195}$.

O contato promovido pela área jurídica do CRAVI entre usuário e promotor ou delegado responsável pelo caso foi bem avaliado pelos entrevistados, como uma forma interessante de promover o acesso à justiça e informar sobre os direitos do cidadão. Entretanto, isso ocorre quando há um pedido do usuário e numa esfera individualizada de cada caso concreto. Um debate público, ainda que nos autos do processo, parece não ser incentivado ou fomentado pelo jurídico do CRAVI sobre o direito de participação das vítimas nos procedimentos judiciais e sobre a reparação.

Nas entrevistas da área jurídica, há uma crítica sutil sobre o "emudecimento" da vítima nos procedimentos judiciais de apuração do crime, visto que a vítima somente surgiria no processo criminal como testemunha. Mas não há uma preocupação no sentido de viabilizar o discurso da vítima no âmbito processual, assegurando a "voz da vítima”.

Mas não basta garantir a "voz da vítima", é preciso também garantir que esse discurso seja escutado e levado em consideração. Numa perspectiva de direitos humanos, não é possível escutar apenas um lado da questão, o fenômeno da violência é complexo e

\footnotetext{
194 “(...) eu acredito que o acolhimento é muito mais difícil que o atendimento. O atendimento jurídico para as pessoas que tem formação jurídica é um atendimento sim pontual, na qual o advogado vislumbra o direito daquela pessoa e as possíveis medidas e ações judiciais que pode tomar. O acolhimento no qual as pessoas não se identificam em termos profissionais e acolhem a vitima em um processo de escuta e de algumas colocações para que a pessoa realmente se coloque e ache todas as questões a partir do episódio violento, eu inicialmente disse que estava em processo de preparação para esse procedimento e não estava ainda confortável em fazer o acolhimento, atendimento jurídico sim, mas acolhimento ainda não. Então eu acredito que ainda lido com essa questão [lidar com vitima de violência] com um pouco de dificuldade" (AJ1)

195 "Também uma outra dificuldade (...) a gente propõe uma eventual demanda cível e não é a gente que acompanha, é distribuído para um fórum regional onde tem um defensor que acompanha, então o usuário retorna ao CRAVI e cobra da gente informações sobre aquele processo mas a gente não tem (...) então a gente mesmo propôs mas precisa encaminhar a parte para o fórum para conversar com o defensor do caso porque a gente não tem acesso." (AJ2)
} 
multifacetado; não apenas o discurso da vítima precisa ser levado em consideração, mas também os direitos do agressor e a dinâmica da violência.

O direito, tradicionalmente regulador de conflitos binários, não se mostra preparado para lidar com questões complexas como a violência e a vitimização. Nem mesmo os advogados e defensores que atuam no atendimento às vítimas de violência dispõem de instrumentos adequados para lidar com essa tarefa. A vítima é observada apenas como instrumento de prova ou como causa de aumento de pena na esfera penal ${ }^{196}$ - como se houvesse um carimbo a ser assinalado em todos os crimes em que a vítima for criança, adolescente, mulher, afrodescendente, homossexual, ou qualquer outra minoria. A proteção às vítimas parece se resumir a esse carimbo de imposição de aumento de pena ao autor do crime; ignorando-se que a vítima pode ter sofrido danos físicos, psíquicos e sociais; que ela pode ser chamada a depor no processo, e que se pode causar outros danos ao relembrar os fatos e reviver a violência, que a vítima tem direito à proteção, participação do processo e reparação integral.

Os direitos humanos devem ser promovidos aliando-se a vertente repressivapunitiva com a vertente promocional. Não basta aumentar o rigor penal. A garantia de não repetição da violação é desconhecida e ignorada. É preciso investir na prevenção sim, mas também na reparação integral da violência sofrida - no aspecto da restituição, satisfação, reabilitação, compensação e garantia de não-repetição.

Os direitos das vítimas são desconhecidos inclusive entre os operadores do direito. Não apenas os direitos de todos, mas também os direitos específicos diante da vulnerabilidade desse grupo vitimado - de acordo com o perfil há especialização da proteção dos direitos humanos. Entretanto, ignoram-se os direitos das vítimas em geral, consagrados na Declaração dos Princípios Fundamentais de Justiça relativos às Vítimas da Criminalidade e de Abuso de Poder (Resolução 40/34, de 1985) e Princípios e Diretrizes Básicos sobre o Direito das Vítimas de Violações das Normas Internacionais de Direitos Humanos e de Direito Internacional Humanitário a Interpor Recursos e Obter Reparações (Resolução 60/147, de 2005).

A legislação nacional também é deficitária em termos de proteção e assistência às vítimas de violência. A vitimização secundária não é rara no percurso da vítima no sistema de justiça - como verificado nas entrevistas - e os centros de referência que prestam

\footnotetext{
${ }^{196}$ Por outro lado, há um discurso exacerbado de vitimização em que todos são, ou podem ser vítimas - o que dificulta uma discussão politizada sobre uma política de atendimento a vítimas de violência e sobre as possibilidades de intervenção jurídica pautadas no respeito e promoção dos direitos humanos.
} 
atendimento às vítimas nem sempre conseguem intervir nesse processo de vitimização com os poucos instrumentos disponíveis para enfrentar essa situação, que depende de uma mudança numa cultura institucional de vitimização e de uma legislação adequada. Ressaltamos que há uma preocupação do CRAVI com o fortalecimento de uma rede com o sistema de justiça, especialmente para sensibilização sobre a vitimização secundária.

Embora o direito tenha um lugar importante no CRAVI, o acesso à justiça pelas vítimas ainda se mostra precário, na medida em que os esforços se concentram basicamente em questões penais, relacionadas ao crime perpetrado; pouco se fala e se faz em relação a outras demandas jurídicas relacionadas à violência sofrida - como reparação, exercício de direitos civis em geral, previdenciário, dentre outros. A impressão é de que a vítima de violência tem seus direitos violados e a resolução se dará apenas na esfera penal. O Direito aqui, parece ser muito mais relacionado a uma esfera punitiva-repressiva, de não-fazer, do que de uma vertente promocional, estimulando ações e políticas.

Embora a demanda por justiça seja grande, pouco sabemos sobre as possibilidades de intervenção jurídica aliada às outras áreas da psicologia e serviço social no atendimento às vítimas. O usual e o mais conhecido ainda é uma orientação jurídica pontual e informações sobre procedimento na esfera penal. A vítima é vista atrelada ao crime, pouco conseguimos enxergar e reparar a situação ou dinâmica de violência relacionada ao fato criminoso, quase nada sabemos sobre essa vítima e pouco fazemos para a efetiva proteção e assistência integral.

Enquanto no CNRVV há uma fraca compreensão sobre os direitos das pessoas atendidas e os instrumentos para a efetivação desses direitos, no CRAVI a equipe em geral parece ter conhecimentos básicos sobre os direitos para informar as vítimas, mas ainda assim com as ressalvas anteriormente mencionadas.

O CNRVV parece não estar mobilizado para prestar o atendimento jurídico. Embora, para parte das entrevistadas, a ausência de um advogado na equipe dificulte o encaminhamento de algumas demandas e a orientação sobre trâmites jurídicos para exercício ou reivindicação de direitos, no discurso de alguns técnicos do CNRVV, isso se mostra desnecessário na medida em que o centro não se propõe a prestar atendimento jurídico e a assessoria jurídica "quando necessária", se mostra adequada para contornar essas questões. Interessante ressaltar que essa aparente desnecessidade do atendimento jurídico se contrapõe às hesitações e limites da própria lei mencionadas nas entrevistas. Embora o Poder Judiciário seja o principal encaminhador para atendimento no CNRVV e 
haja queixas sobre impunidade dos agressores, as questões jurídicas não são vistas como possibilidades de intervenção e talvez por isso não sejam trabalhadas.

$\mathrm{O}$ papel do direito no atendimento interdisciplinar às vítimas de violência é entendido como limite, regra de convivência ou punição para a equipe do CNRVV. As questões jurídicas parecem ignoradas e trabalhadas num viés psicológico ou social. A revitimização é uma dificuldade enfrentada cotidianamente, mas não é encarada como um campo de atuação do centro. A assessoria jurídica é esporádica e apenas para os casos "mais urgentes ou complicados".

Para a equipe do CRAVI, o direito deve promover o acesso à justiça e portar a lei no caso da violência. A área jurídica realiza orientação, informa os técnicos sobre os direitos e procedimentos envolvidos, e, também, acompanhamento processual, sem intervir no processo como representante da vítima. Ao mesmo tempo, a área jurídica precisa estar integrada com as demais áreas de atendimento, para efetiva proteção e assistência às vítimas. O advogado não pode ser só advogado e deve usar "roupa normal" nos atendimentos, especialmente nos acolhimentos.

A ausência do Estado possibilita a atuação do poderoso local e a reprodução de uma situação de violência ainda mais perversa, mas não percebida como tal pelos envolvidos nessa dinâmica - como mencionado por E $6^{197}$. A proteção à vítima é prejudicada diante da carência da rede de proteção real. É o que ressalta também AJ3 ${ }^{198}$ ao comentar que a criança, quando encaminhada para a rede atendimento, diante da suspeita de abuso sexual, tem sua história desconstruída nesse momento - o processo é dolorido e pode ser mais sofrido que a violência em si.

Embora a ausência de advogados na equipe do CNRVV seja contornada pelo contato maior com a equipe técnica do Judiciário para encaminhamento de questões relativas a procedimentos judiciais e uma assessoria jurídica esporádica, as vítimas com

197 “(...) você identifica uma situação de violência, e quando o Estado não consegue dar essa proteção para essa família o que tem acontecido, que eles têm relatado é que essas pessoas vão para o tráfico, para aquele poderoso da comunidade e conta o que está acontecendo. Ai os caras vão lá, os manos e enquadram o cara, oferecem uma proteção para essa mãe, arruma onde morar e não sei o que, só que essa mulher não está se dando conta que ela está saindo de uma situação de agressão e entrando em outra que tem tanto ou maior prejuízo do que ela tinha anterior. Quer dizer está numa situação de proteção e agressão misturadas. E que modelo maluco é esse? Essa mulher que está tão, no caso é a mulher que está nessa situação, o quanto ela acaba repetindo esse modelo porque ela sai de um agressor e vai para o outro e a coisa vai se repetindo, então se não tiver um trabalho, de um atendimento para que ela possa se trabalhar e se conhecer, senão ela só vai mudando de agressor, a proteção e o agressor, não esse tá fazendo isso comigo mas o outro vai fazer diferente, e não muda." (E6)

${ }^{198}$ Foram entrevistados, além dos profissionais da área jurídica do CRAVI, dois advogados, militantes e defensores de direitos humanos, com experiência no atendimento interdisciplinar a vítimas de violência objeto dos centros estudados. 
questões jurídicas permanecem desamparadas. A determinação judicial de possibilitar a visita da criança ao suposto agressor em visitário público foi constantemente comentada e criticada pelas entrevistadas. Apenas a mãe ou responsável "mais fortalecida" descumpriria essa determinação para proteção da criança - numa perspectiva individual, de empoderamento psicológico ou social - sem uma orientação sobre os direitos dessa criança vitimizada e da possibilidade de proteção ou recurso à decisão judicial. As questões jurídicas não são consideradas muito relevantes ao atendimento e o contato com a equipe técnica do judiciário poderia suprir muitas demandas... em alguns casos. Mas não garante o acesso ao direito e à justiça.

No CRAVI, por outro lado, embora tenha uma área jurídica, o desamparo ainda é realidade. Conforme entrevistas, a parceria entre a DPESP e a SJDC não favorece a troca entre técnicos em razão da pouca permanência dos defensores no CRAVI e da falta de integração pela ausência nas reuniões de equipe. Essa integração prejudicada foi avaliada pelos entrevistados como uma perda da qualidade do atendimento jurídico em relação ao modelo anterior em que os atendimentos jurídicos eram realizados por advogados, que faziam parte da equipe e participavam de todas as atividades da instituição. Ao contrário do CNRVV, a coordenação do CRAVI tem preocupação com o atendimento jurídico e apesar dos esforços para adequação do convênio com a DPESP, o atendimento jurídico enfrenta outros problemas além da descontinuidade da linha de atuação da instituição pública.

A noção de direitos humanos é fraca no discurso dos técnicos do CNRVV e a percepção se confunde com o Estatuto da Criança e do Adolescente. A equipe adere ao discurso dos direitos humanos, mas não demonstra ter compreensão sobre a concepção contemporânea dos direitos humanos - como se os casos atendidos não tivessem repercussão em outras esferas além dos direitos das crianças e dos adolescentes previstos no Estatuto. Já no CRAVI, uma instituição pública, o discurso dos direitos humanos é presente e conhecido pela equipe, especialmente no tocante ao acesso à justiça. Embora o atendimento em si não promova direitos humanos e atue mais na linha de defesa e proteção, a equipe indica a necessidade de maior investimento na prevenção.

Explicitar os direitos é importante, mas depende do contexto e da condição da vítima, se ela consegue ou não escutar e se faz ou não sentido para ela naquele contexto. Não deve ser um procedimento independentemente da situação da vítima e do caso. A informação sobre os direitos é realizada conforme a condição da vítima e do caso; e 
depende, preliminarmente, do conhecimento dos direitos das vítimas pela equipe. Uma equipe que desconhece os direitos humanos e os instrumentos de defesa e proteção dificilmente conseguirá informar e orientar o público atendido.

O maior desafio em relação aos direitos humanos parece ser a coerência entre o discurso e a prática institucional. Embora o CRAVI seja um programa de direitos humanos, nem sempre os atendimentos são realizados com esse fim - vide comentário de E14 ${ }^{199}$ sobre o cuidado com a equipe e sobre os encaminhamentos em casos de violência policial ou parceria para peticionar casos perante a Comissão Interamericana de Direitos Humanos.

A construção das parcerias parece ser outro tema complicado na prática dos centros. Se o tema de trabalho exige uma articulação da rede de serviços para encaminhamentos pertinentes e necessários, a rede se mostra insuficiente, inadequada e até inexistente. A rede está em constante modificação (inclusive em razão de falta de financiamento para os projetos e fechamento de serviços), o que exige dos técnicos dos centros contatos e atualização permanente. $O$ trabalho em rede impõe que cada instituição se admita incompleta para uma troca efetiva e mutua. No entanto, a relação de parceria exige uma construção e definição de atribuições claras, respeitando-se os objetivos das instituições relacionadas - evitando-se uma parceria que às vezes se mostra ambígua, como no caso da SJDC e SSP. A relação entre parceiros institucionais não deve negar ou prejudicar os objetivos de cada entidade, mas promover a ampliação da reciprocidade e concretização de objetivos comuns. A parceria que nega ou ignora equívocos da outra entidade não se mostra uma relação adequada à promoção dos direitos humanos e ao próprio atendimento às vítimas de violência.

Os casos exemplares mencionados pela equipe do CNRVV indicam casos de sucesso, em que o resultado do atendimento é observado, ou que há a necessidade de intervenção da rede de serviços, indicando impasses e necessidade de apoio.

\footnotetext{
199 “(...) eu não consigo entender como o CRAVI que vai trabalhar com a defesa e proteção dos direitos ser uma instituição tão frágil e que é tão incompetente com os direitos dos seus próprios funcionários, que resvala sim para a população (...) Foi dito também que a gente não poderia mais levar os casos para a Comissão Interamericana, que a gente não estava autorizada a fazer isso. Então é uma visão que às vezes não me dá muita perspectiva de que a gente está indo na linha mesmo de quebrar o silêncio e de proteger os direitos humanos, parece que muitas vezes a gente vai reforçando isso, essas violações, e esse eu acho que é o maior perigo disso acontecer, você está em um lugar muito privilegiado de fazer isso acontecer, de fazer as pessoas se calarem, as pessoas estão aqui, dependendo da direção... (...) Às vezes a gente diz, só que quando alguém lá de cima precisa bancar, não banca e aí você fica com as pernas cortadas (...) Não vai poder mais falar aqui dentro de crimes de policiais porque são agentes do Estado? então que noção que se tem do que é violência nessa Secretaria? para mim nenhuma, porque é só olhar os dados que vai ver.” (E14)
} 
Por outro lado, a equipe do CRAVI teve grande dificuldade em relatar casos exemplares - metade dos entrevistados não conseguiu comentar sobre um caso considerado emblemático - e os casos descritos pelos entrevistados demonstram resultados observados nos atendimentos, mas sem o caráter da necessidade de intervenção da rede como verificado nos casos do CNRVV. É interessante que os casos relatados indicam, de certa forma, as diversas questões afloradas nas entrevistas. O perfil das vítimas, o atendimento realizado, as dificuldades enfrentadas, a relação com a vítima, com o direito e as possibilidades concretizadas.

Mesmo uma instituição ligada ao estado, como o CRAVI, sofre com a descontinuidade do serviço e talvez por esse motivo a sensação de que os casos "se perdem" na instituição e a dificuldade em relatar um êxito. Parece que ao não conseguir descrever um caso emblemático, permanece a idéia da dificuldade e talvez um desafio presente nos centros seja manter aquele entusiasmo, a motivação mencionado por $\mathrm{E} 7^{200}$, porque fica uma impressão de que, por mais difícil que seja lidar com o tema da vítima de violência e suas implicações, mais complicado ainda é ter que trabalhar contando com tantos outros problemas relacionados à condição de trabalho interna (no centro) e externamente junto à rede de serviços, à insuficiência de recursos e instituições públicas, além da precariedade da legislação e instrumentos de proteção e assistência às vítimas. Ainda assim, os técnicos continuam enfrentando essas adversidades e prestando o atendimento às vítimas de violência.

\section{O direito no atendimento às vítimas de violência: um lugar a ser construído}

Conforme o discurso dos técnicos do CRAVI, o principal entrave para o atendimento jurídico parece ser o formato da parceria entre SJDC e Defensoria Pública, que prevê a realização do atendimento jurídico pelos defensores públicos em regime de plantão por um período determinado (antes de seis meses, agora um ano) - o que não possibilita a permanência dos defensores públicos no CRAVI e dificulta a interação dos técnicos. A crítica ao modelo atual leva em consideração o atendimento jurídico anterior, o qual dialogava com mais facilidade com os demais técnicos e era realizado por advogados que participavam de todas atividades da instituição.

\footnotetext{
200 "eu acho que o maior desafio é esse, fazer com que o trabalho seja sempre motivador, porque eu acho muito desagradável trabalhar com essa área e você ser um muro de lamentações, então as pessoas tem que estar sempre trabalhando numa postura mais otimista diante das coisas, acho que o maior desafio é esse, é poder manter uma posição de entusiasmo com a vida, com as coisas, independente de trabalhar com isso, senão você fica uma vítima também, não é verdade?!" (E7)
} 
Embora a parceria instalada entre SJDC e DPESP de fato dificulte a interação entre os técnicos na medida em que não possibilita a participação dos defensores públicos em todas reuniões de equipe e a convivência diária com a equipe fique prejudicada pelo regime de plantão, uma outra questão relevante se impõe nesse cenário.

Como é vista e tratada a vítima nas políticas de atendimento? Qual a relevância dessa política para o poder público e para a sociedade em geral? Qual a contribuição do direito no atendimento interdisciplinar a vítimas de violência? Qual lugar tem ocupado no CRAVI e no CNRVV?

Muitas organizações que prestam atendimento às vítimas não oferecem atendimento jurídico - como é o caso do CNRVV. Mesmo considerado relevante, o atendimento jurídico parece não ter sido incorporado pela instituição como uma forma relevante de intervenção interdisciplinar. $\mathrm{O}$ atendimento jurídico é considerado importante para a maioria dos técnicos entrevistados do CRAVI, uma parte importante do trabalho do CRAVI como se verifica com E6: o trabalho desenvolvido na instituição foi "amputado" com a mudança da composição da área jurídica e, consequentemente, do atendimento jurídico prestado ${ }^{201}$.

Entretanto, analisando-se a experiência do atendimento prestado nos dois centros e o encaminhamento das questões jurídicas decorrentes, verificamos que o papel do jurídico nesses centros não tem contornos muito definidos, mas está afastado das outras áreas de atendimento. No caso do CNRVV esse atendimento jurídico sequer é considerado relevante ou necessário aos casos atendidos. No CRAVI, uma experiência interessante de construção interdisciplinar aliando a perspectiva jurídica foi interrompida para ser reconstruída com outros atores, os defensores públicos.

Nesse cenário, parece relevante refletirmos não apenas sobre como a instituição considera a contribuição dos aspectos jurídicos no atendimento às vítimas de violência, mas como o poder público se posiciona frente a essa questão. Embora o Programa Sentinela tenha uma previsão de apoio psicossocial e jurídico às crianças e adolescentes em situação de abuso ou exploração sexual e às famílias, há uma indicação de que esse apoio jurídico seja realizado com a articulação da rede, especialmente os Centros de Defesa da Criança e do Adolescente e a Defensoria Pública. Em São Paulo, por exemplo, o

201 "Tudo isso, toda essa riqueza dessa construção do trabalho do jurídico interdisciplinar, a gente perdeu, não que a gente tenha esquecido do que era, ou que a gente não precisa mais, eu falo de uma perda porque a gente sabe da importância, amputou um pedaço do trabalho do CRAVI para mim "(E6) 
convênio da SMADS com CNRVV não prevê o atendimento jurídico, que deve ser realizado em parceria e articulação da rede.

Em relação ao CRAVI, embora vinculado à Secretaria da Justiça e da Defesa da Cidadania, o atendimento jurídico também não se mostra relevante. De acordo com as entrevistas, não há uma compreensão plena por parte da Secretaria sobre a forma de trabalho desenvolvida no CRAVI, a "ponte" é construída com dificuldade, e os investimentos públicos no programa são insuficientes. $\mathrm{O}$ atendimento jurídico nem sempre é compreendido como forma de proteção da vítima, e o direito às vezes é visto por um viés burocrático $^{202}$ ou de forma pontual a ser resolvida num plantão do defensor público. Mas dificilmente como forma de acesso à Justiça e exercício de direitos, e mais raramente de forma integrada a outras áreas.

Pouco ainda se sabe sobre as possibilidades de intervenção conjunta do atendimento jurídico, psicológico e social a vítimas de violência. $\mathrm{O}$ atendimento jurídico pode dar maior visibilidade a algumas questões do atendimento às vítimas de violência, como a vitimização secundária, o exercício de direitos, acesso à justiça, dentre outras. A própria instituição às vezes demonstra certa ambigüidade ao não prover suporte e respaldo necessário aos técnicos que questionem tais impasses - o jurídico, nesse sentido, pode potencializar alguns debates em âmbito judicial; mas nem sempre a instituição apóia essas medidas, conforme se depreende nas entrevistas do CRAVI.

Não apenas o atendimento jurídico interdisciplinar parece ser pouco conhecido. A vítima praticamente não existe para o Estado e às vezes é invisível para os próprios operadores do direito, inclusive aos defensores públicos. O sistema de justiça revitimiza constantemente, como observado nas entrevistas realizadas, delegados de polícia, promotores de justiça e juízes de direito ignoram as vítimas, exceto quando representam alguma prova a ser incluída no inquérito policial ou no processo judicial, ou quando a identidade da vítima representam algum critério de fixação da pena do autor do crime.

A invisibilidade da vítima pode ser verificada também em relação aos debates sobre a violência, pautados em geral por maior repressão e rigor punitivo em aparente oposição a prevenção e consolidação de políticas públicas de segurança. As medidas legislativas em vigor pouco se debruçam sobre a vitimização e os projetos de lei em tramitação no Congresso Nacional raramente se dedicam ao atendimento às vítimas.

${ }^{202} \mathrm{O}$ assessor jurídico do CRAVI não presta atendimento às vítimas, apenas excepcionalmente em caso de emergência e ausência de defensor público; mas tinha responsabilidades administrativas, como elaboração de um regimento interno do centro, analise de contratos e parcerias do CRAVI, dentre outras atividades. 
Por outro lado, a noção de vítima é disseminada e todos podem se sentir ou se tornar vítimas $^{203}$, ligando-se à idéia de sofrimento e geralmente associada a reações emocionais diante da violência iminente. Essa polarização da noção de vítima - ora invisibilizada, ora disseminada (todos são vítimas de violência) - não favorece a delimitação do lugar da vítima como um sujeito de direito e da consolidação de uma política de atenção e apoio às vítimas.

A vítima de violência sofreu uma violação de direito, embora nem todas violações de direito impliquem na existência de uma vítima. A pessoa está numa situação de vítima, não se trata de uma posição estática e cristalizada, pois a dinâmica da violência pode implicar em mudanças de papéis de agressão e vitimização. A vítima pode ter sido direta ou indiretamente atingida pela violência; não importa se a pessoa vitimada praticou algum ilícito anterior à violência sofrida ou se é “inocente”. Ninguém é mais ou menos vítima. A vítima pode ter "perdido toda a capacidade de resistência, inclusive de dizer que não gosta de jiló" (AJ3) ou estar numa posição de passividade ou desproteção. A pessoa vítima deve ter sua dignidade humana respeitada e qualquer intervenção (não apenas no atendimento, mas também no percurso do sistema de justiça, durante os cuidados médicos etc) deve levar em consideração sua identidade e história de vida, evitando-se danos ou lesões desnecessárias.

$\mathrm{O}$ atendimento às vítimas de violência deve considerar toda a complexidade envolvida em cada caso. $\mathrm{O}$ atendimento jurídico ainda precisa ser desvendado e construído de forma integrada às demais áreas do atendimento. $\mathrm{O}$ isolamento da área jurídica não se mostra uma opção razoável para o enfrentamento de situações de violência e vitimização.

$\mathrm{O}$ advogado numa equipe multiprofissional pode "impermeabilizar" o atendimento jurídico estritamente ou tentar se integrar com outros técnicos da demais áreas - para isso ele precisa aprender outro idioma, a linguagem da outra área de atendimento. Da mesma forma, os outros técnicos eram constantemente convidados a repensar a prática e construir a interdisciplinaridade com a área jurídica, numa hermenêutica diatópica.

"Os técnicos tinham dificuldade de compreender, como a gente tem até hoje, de compreender o universo jurídico que faz parte do ECA do campo protetivo, então essas questões de boletim de ocorrência, de representação processual, de como as crianças continuam vindo no atendimento e os agressores continuam convivendo com a criança, isso frustrava um pouco os técnicos, não que isso tenha mudado" (AJ3)

\footnotetext{
${ }^{203}$ Não entraremos na discussão sobre vítima virtual e a disseminação do medo. Também não será analisada a questão da desigualdade social e o "medo da classe média" diante da violência iminente e a"banalização" da violência cotidianamente perpetrada nas periferias urbanas.
} 


\begin{abstract}
"um espaço de escuta onde interdisciplinarmente ou às vezes multidisciplinarmente eram discutidos os casos e tínhamos a possibilidade de experimentar como o direito navegaria, ou como o direito conseguiria construir um viés nessa interdisciplinariedade, porque também existe um outro lado da história que é o preconceito que existia e sempre existiu com o universo do direito." (...) tinha uma dificuldade de compreender inclusive qual era o nosso lado de proteção, que em alguns momentos em que a gente discutia um tema delicado (...) que elas avaliavam esse corte como uma perspectiva violenta e a gente entendia que do que existe no processo de adoção isso era uma garantia legal, o juiz poderia fazer isso, então em alguns momentos a gente era confundido do lugar que a gente estava de proteção, como acusador às vezes, então era meio difícil, mas muito interessante." (AJ3)

"tinham duas opções, ou você impermeabilizava e fazia um atendimento estritamente jurídico o que levava a dificuldade de de repente ter uma situação de atendimento bastante difícil, ou então procurava descobrir novas linguagens de disciplinas ali, tinha que aprender um novo idioma, um novo jeito de falar também, uma nova compreensão, então tem que desenvolver uma certa abertura, você começa a cobrar essa abertura também. (...) se eu não fizesse isso eu enlouquecia porque ia ficar totalmente isolado." (AJ4)
\end{abstract}

$\mathrm{O}$ direito no atendimento às vítimas de violência não pode ser apenas procedimental, é necessário conjugar o processo com a perspectiva humana, da dignidade humana. A vítima, quando considerada e tratada pelo sistema de justiça como instrumento de prova pode significar suportar mais uma violência, além da violência sofrida. $O$ advogado ou defensor que faça o atendimento às vítimas de violência deve estar atento aos riscos de vitimização secundária, pois o processo judicial deveria ser também um espaço de proteção (ainda que nossa legislação ainda seja deficitária nesse aspecto) - proteção para a vítima e também para o agressor.

$\mathrm{O}$ atendimento às vítimas de violência deve ser pautado nos direitos humanos e nesse sentido, mediar as relações com base no respeito e promoção da dignidade humana analisando-se o contexto, as pessoas envolvidas, a dinâmica da violência, as histórias de vida, a multiplicidade e complexidades dos conflitos com diversas partes envolvidas. Nesse contexto, uma punição mais severa do agressor não soluciona a questão e pode até violar direitos do autor da violência. A defesa e promoção dos direitos das vítimas de violência não pode ignorar ou desprezar garantias fundamentais, como o devido processo legal, presunção de inocência, ampla defesa, dentre outros.

Numa perspectiva de direitos humanos, o atendimento às vítimas deve respeitar igualmente os direitos dos acusados e réus. Os direitos das vítimas não se resumem na esfera penal, há que se ampliar esse debate e articular a defesa dos direitos de natureza civil, previdenciária, além do acesso à justiça e reparação integral. A reparação integral que inclui a restituição, compensação, reabilitação, satisfação e garantia de não-repetição é pouco conhecida. 
Nos centros estudados, o aspecto jurídico abrange apenas a orientação jurídica e acompanhamento processual criminal - raramente é feito algum encaminhamento para indenização civil. A construção do campo de atuação do advogado ou defensor no atendimento a vítimas de violência deve levar em consideração a potencialidade da atuação com base no acesso à justiça e no direito de reparação integral.

A discussão sobre a proteção da vítima e do agressor no decorrer do procedimento no sistema de justiça, evitando-se a vitimização secundária, também não deve ser ignorada pela área jurídica no atendimento a vítimas.

O efetivo acesso à justiça não é exercido exclusivamente pelos profissionais da área jurídica; é preciso a interação com outras áreas inclusive para uma intervenção jurídica mais adequada e protetiva. Uma perspectiva estritamente procedimental do direito não se mostra adequada, é preciso explorar uma abordagem dos direitos. É necessário ampliarmos e aprofundarmos a discussão sobre os direitos de proteção, participação e reparação da vítimas. Para tanto temos também que descobrir novas possibilidades, outras interpretações e incorporar os direitos humanos no atendimento às vítimas de violência.

Procedimentos judiciais que se referem a situações de violência não tem as mesmas características de outros procedimentos; exigem dos operadores do direito outros conhecimento além da técnica jurídico-processual. Como comentado pelos profissionais da área jurídica, as outras áreas de conhecimento podem contribuir para uma intervenção jurídica mais pertinente. E às vezes o atendimento jurídico pode proporcionar outros campos de atuação para a psicologia e serviço social - nos casos de violência fatal, por exemplo, às vezes a leitura dos autos de inquérito policial arquivado num atendimento jurídico possibilita um resgate da história da vítima direta e um campo de intervenção psicológica ou social que dificilmente seria viável sem essa intervenção jurídica, ainda que o campo de atuação estritamente jurídica seja aparentemente mínimo (já que a investigação estava concluída e os autos do inquérito policial arquivado). Por outro lado, após essa abertura e atendimento psicológico e/ou social, o trabalho jurídico pode ser de fato viabilizado na medida em que passa a fazer sentido para a vítima de forma protetiva.

Essa construção interdisciplinar não é simples. O discurso psicossocial tem algumas técnicas semelhantes às quais o discurso jurídico não tem tanta familiaridade e pode ficar isolado. A abertura das disciplinas para um dialogo interdisciplinar exige também que cada área tenha seu campo de atuação delimitado para que, por exemplo, o atendimento jurídico não se descaracterize e assuma um foco mais psicológico ou mais social e perca a 
concretude do fato jurídico, que pode ser minimamente mensurado (por exemplo, condenação, denúncia, processo etc). Esse risco de descaracterização pode também causar uma revitimização, pois os direitos podem ser violados, ou violados por não terem sido defendidos tecnicamente, o acesso à justiça pode ser inviabilizado, dentre outras possibilidades. Se o advogado sai do seu lugar no atendimento à vítima, ele também vitimiza.

Entretanto, esse lugar do direito no atendimento às vítimas de violência está em construção, e depende de cada caso em questão. Para um dos entrevistados, é montar um quebra-cabeças nunca visto. O papel do advogado ou defensor é de observador dos procedimentos e das garantias, ao mesmo tempo que é um "pára-raios" ou uma "ponte" para a vítima, os técnicos e o sistema de justiça. Ao mesmo tempo que pode ser o principal agente para acesso à justiça, o advogado ou defensor não é necessariamente imprescindível para o acesso à justiça.

Outras dificuldades se impõem nessa construção do lugar do direito: a formação jurídica não privilegia a troca com outras disciplinas; o profissional pode se formar e buscar outras discussões e formações para uma intervenção conjunta; mas às vezes não há instrumentos adequados e é preciso criar outras possibilidades. Às vezes lidar com o sistema de justiça é a maior dificuldade.

A legislação não é adequada para proteção e reparação das vítimas. As políticas de atendimento às vítimas não viabilizam de fato um debate sobre a vítima e sobre as dinâmicas de violência. Há um investimento público no atendimento às vítimas de violência, mas sem uma possibilidade instituída e garantida de efetiva promoção dos direitos das vítimas e de discussão política sobre a violência e a vitimização.

A falta de autonomia e de estrutura adequada não impedem o atendimento às vítimas, mas não favorece uma politização das diversas questões que envolvem esse trabalho, como a violência fatal, o abuso e exploração sexual, dinâmicas violentas no âmbito doméstico, desproteção da vítima no sistema de justiça, possibilidades de reparação, dentre tantas outras questões relacionadas.

$\mathrm{O}$ atendimento às vítimas de violência que não se propõe modificar esse cenário para garantir maior proteção e reparação das vítimas, com respeito aos direitos humanos, pode perpetuar uma vitimização e sutilmente educar e controlar essas vítimas para que não exerçam e nem exijam seus direitos. 
O serviço é oferecido, mas não se proporcionam as condições adequadas para tanto. A instabilidade do financiamento, a fragilidade da instituição, a inadequação das medidas legislativas, a precariedade da política pública, a insensibilidade do sistema de justiça com a vítima. Mesmo com tantas dificuldades, os técnicos ainda abrem a porta e conseguem fazer um bom atendimento a essas vítimas.

O lugar do direito a ser desvendado no atendimento a vítimas de violência pode trilhar isoladamente ou buscar a interlocução com outras áreas; pode privilegiar o direito como instrumento de direção e promoção social ou como técnica de controle e regulação. Mas não se deve ignorar as potencialidades de atuação baseada nos direitos humanos, a necessária articulação entre a teoria e a prática, e as possibilidades de contribuição efetiva do direito na consolidação de uma política de atendimento às vítimas de violência que promova efetiva proteção e reparação das vítimas de violência. 


\section{BIBLIOGRAFIA}

AMARAL JUNIOR, Alberto; PERRONE-MOISÉS, Claudia (orgs.). O Cinqüentenário da Declaração Universal dos Direitos do Homem. São Paulo: Editora da Universidade de São Paulo, 1999.

BAUMAN, Zygmunt. Modernidade e ambivalência. Rio de Janeiro: Jorge Zahar Editor, 1999. . Em busca da política. Rio de Janeiro: Jorge Zahar Ed., 2000. . Modernidade líquida. Rio de Janeiro: Jorge Zahar Ed., 2001. - Comunidade: a busca por segurança no mundo atual. Rio de Janeiro: Jorge Zahar Ed., 2003.

BICUDO, Tatiana Viggiani. A globalização e as transformações no direito penal. In: Revista Brasileira de Ciências Criminais nº. 23, ano 6, julho-setembro/1998, p.97-109.

BOBBIO, Norberto. A era dos direitos. Trad. Carlos Nelson Coutinho. Rio de Janeiro: Campus, 1992.

BRASIL. Relatório Nacional Brasileiro: Convenção sobre a eliminação de todas as formas de discriminação contra a mulher, Protocolo Facultativo. Coordenação de Flávia Piovesan e Silvia Pimentel. Brasília: Ministério das Relações Exteriores, Ministério da Justiça, Secretaria de Estado dos Direitos da Mulher, 2002.

Impacto da campanha do desarmamento no índice nacional de mortalidade por arma de fogo. Ministério da Saúde, agosto de 2005. Disponível em: www.rolim.com.br/2002/_pdfs/pesquisa_min_saude_mortalidade_armas.pdf (acesso em 26/01/08).

. Plano Nacional de Enfrentamento da Violência Sexual Infanto-Juvenil: uma política em movimento - Relatório de Monitoramento 2003-2004. Brasília, 2006.

BUVINIC, Mayra; MORRISON, Andrew; SCHIFTER, Michael. Violence in Latin America and the Caribbean: a framework for action. Inter-American Development Bank, March 1999. Extraído do site: http://www.iadb.org/sds/doc/1073eng.pdf Data de acesso: 04/08/04.

CAPPELLETTI, Mauro; GARTH, Bryant. Acesso à Justiça. Porto Alegre: Sergio Antonio Fabris Editor, 1988. 
CARDIA, Nancy; ADORNO, Sérgio; POLETO, Frederico. Homicídio e violação de direitos humanos em São Paulo. In: Estudos Avançados 47. São Paulo: USP, IEA, janabr/2003, p. 43-73.

CARVALHO, José Sérgio Fonseca de. Podem a ética e a cidadania ser ensinadas?. In: Jovens Lideranças Comunitárias e Direitos Humanos. São Paulo: Imprensa Oficial, 2004, p. 37-47.

CNRVV. O Fim da Omissão: a implantação de pólos de prevenção à violência doméstica. São Paulo, maio de 2004.

COMPARATO, Fábio Konder. Afirmação Histórica dos Direitos Humanos. $2^{\mathrm{a}}$ edição, São Paulo: Ed. Saraiva, 2001. - Fundamento dos Direitos Humanos. Cultura dos Direitos Humanos. São Paulo: ed. LTr, 1998, p.53-74.

CRAVI. Documento de apresentação do Centro de Referência e Apoio à Vítima (CRAVI), elaborado pelo coordenador geral, em maio de 2004.

DALLARI, Dalmo de Abreu. Direitos Humanos no Brasil: uma conquista difícil. In: Pesquisas $n^{\circ}$ 11. 50 anos da Declaração Universal dos Direitos Humanos. Konrad Adenauer Stiftung, Centro de Estudos Brasil, 1999, p. 33-51.

DEACON, Roger; PARKER, Ben. Educação como sujeição e como recusa. In: SILVA, Tomaz Tadeu. O sujeito da educação: estudos foucaultianos. $5^{\text {a }}$ edição, Petrópolis: Editora Vozes, 2002.

DEJOURS, Christophe. A banalização da injustiça social. $5^{\text {a }}$ edição, Rio de Janeiro: Editora FGV, 2003, p. 27-36.

DONNELLY, Jack. Universal Human Rights in Theory and Practice. $2^{\mathrm{a}}$ ed., Ithaca, NY: Cornell University Press, 2003, p.109-124.

DWORKIN, Ronald. Rights as Trumps. In: WALDRON, Jeremy. Theories of Rights. NY: Oxford University Press, 1984, p.153-167.

FARIA, José Eduardo. Direitos humanos, direitos sociais e justiça. São Paulo: Malheiros Editora, 1998.

FERNANDES, Antonio Scarance. O papel da vítima no processo penal. São Paulo: Malheiros Editores, 1995, p.30-56 e 222-236.

FLORES, Joaquín Herrera. Direitos Humanos, Interculturalidade e Racionalidade de Resistência, mimeo. 
FRANCO, Maria Sylvia de Carvalho. Homens livres na ordem escravocrata. $4^{\mathrm{a}}$ edição, São Paulo: Unesp, 1997, p.21-63.

Guia de Recomendações Metodológicas para Atenção aos familiares de vítimas fatais. Resultado de pesquisa realizada pelo Núcleo de Violência da Faculdade de Serviço Social da PUC/SP em parceria com o Centro de Referência e Apoio à Vítima de Violência CRAVI - da Secretaria da Justiça e Defesa da Cidadania do Governo do Estado de São Paulo, com apoio da FAPESP, 2003.

GONZÁLEZ, Paulina Vega. O papel das vítimas nos procedimentos perante o Tribunal Penal Internacional: seus direitos e as primeiras decisões do Tribunal. Sur - Revista Internacional de Direitos Humanos, São Paulo, ano 3, número 5, 2006.

HENKIN, Louis e outros. Human Rights. NY: New York Foundation Press, 1999, p.92116.

IANNI, Octavio. A sociologia numa época de globalismo. In A sociologia no horizonte do século XXI. São Paulo: Boitempo Editorial, 1997, p.13-25.

IBGE. Síntese de Indicadores Sociais 2003. Estudos e Pesquisas n. 12, Rio de Janeiro, IBGE, 2004.

IBGE. Sintese de Indicadores Sociais 2005. Rio de Janeiro, IBGE, 2006. Disponível em: http://www.ibge.gov.br/home/estatistica/populacao/condicaodevida/indicadoresminimos/si nteseindicsociais2005/default.shtm (acesso em 26/01/08).

IKAWA, Daniela. Universalismo, relativismo e direitos humanos. In: Direito Internacional dos Direitos Humanos: estudos em homenagem à Profa. Flavia Piovesan. RIBEIRO, Maria de Fátima (coord.), Curitiba: Juruá, 2004, p.117-126.

ILANUD. Das Políticas de Segurança Pública às Políticas Públicas de Segurança. São Paulo, 2002.

. A questão da segurança pública. São Paulo, 2002.

KAMIMURA, Akemi. "Linguagem e efetivação dos direitos humanos: o desafio do Direito no atendimento interdisciplinar a vítimas de violência”. Monografia apresentada ao curso de Especialização em Direitos Humanos da Faculdade de Direito da USP, como parte dos requisitos para obtenção do título de especialista. São Paulo, 2004. . "Linguagem e Efetivação dos Direitos Humanos: o desafio do Direito no atendimento interdisciplinar a vítimas de violência”, in: Piovesan, Flávia; Ikawa, Daniela (coords.). Direitos Humanos: fundamento, proteção e implementação. Curitiba: Juruá, 2007, v. 2, p. 805-822. 
. "Linguagem e Efetivação dos Direitos Humanos: o desafio do Direito no atendimento interdisciplinar a vítimas de violência", Revista Urutágua, n. 07, agonov/2005. Disponível em: http://www.urutagua.uem.br/007/07kamimura.htm （acesso em 22/08/2005).

. "A vítima de violência no sistema de proteção dos direitos humanos: um estudo sobre a experiência do Tribunal Penal Internacional"; trabalho apresentado durante o III Encontro Anual da ANDHEP, realizado entre 3 e 6 de setembro de 2007.

LAFER, Celso. A reconstrução dos Direitos Humanos: um diálogo com o pensamento de Hannah Arendt. São Paulo: Companhia das Letras, 1988.

LARROSA, Jorge; SKLIAR, Carlos (orgs.). Habitantes de Babel: políticas e poéticas da diferença. Belo Horizonte: Autêntica, 2001.

MARTINS, José de Souza. Sociabilidade do homem simples. Cotidiano e história na modernidade anômala. São Paulo: Hucitec, 2000, p.17-54.

MOURA, Ana Cristina Marcondes [et al.]. Reconstrução de vidas: como prevenir e enfrentar a violência doméstica, o abuso e a exploração sexual de crianças e adolescentes. São Paulo : SMADS. SEDES Sapientae, 2008.

NAVCV - Núcleo de Atendimento às Vítimas de Crimes Violentos. Coletânea do IV Seminário "Construção da Cidadania: os impasses no atendimento às vítimas de violência" - palestras e debates. Belo Horizonte, 2004.

. Coletânea do V Seminário: "Construção da cidadania: desdobramentos dos atendimentos às vítimas de violência”. Belo Horinzonte, 2005.

. Coletânea do VI Seminário: “Construção da cidadania: violência, vítima e direitos humanos". Belo Horinzonte, 2006.

OLIVEIRA, Ana Sofia Schimidt de. A vítima e o processo penal. São Paulo: Editora RT, 1999.

OMS/WHO. World Report on Violence and Health, October 2002. Disponível em: http://www.who.int/violence_injury_prevention/violence/world_report/en. (acesso em: 02/08/04).

ONU. Declaração dos Princípios Fundamentais de Justiça Relativos às Vitimas da Criminalidade e de Abuso de Poder. Resolução 40/34, adotada pela Assembléia Geral do Alto Comissariado das Nações Unidas para os Direitos Humanos, em 29 de novembro de 1985. 
ONU. Princípios e Diretrizes Básicos sobre o Direito das Vítimas de Violações das Normas Internacionais de Direitos Humanos e do Direito Internacional Humanitário a Interpor Recursos e Obter Reparações. Resolução 60/147, adotada pela Assembléia Geral das Nações Unidas, em 16 de dezembro de 2005.

PANIKKAR, Raimundo. É a noção dos direitos do homem um conceito ocidental? In: Diógenes: Revista Internacional de Ciências Humanas nº 05, UnB, 1983, pp.5-29.

PIMENTEL, Silvia; SCHRITZMEYER, Ana Lúcia Pastore; PANDJIARJIAN, Valéria. Estupro: crime ou "cortesia”? Abordagem sociojurídica de gênero. Porto Alegre, Sergio Antonio Fabris Editor, 1998.

PINHEIRO, Paulo Sergio (et al.). São Paulo sem medo: um diagnóstico da violência urbana. Rio de Janeiro: Garamond, 1998.

PIOVESAN, Flávia. Direitos Humanos e Justiça Internacional. São Paulo: Saraiva, 2006. Direitos Humanos e o Direito Constitucional Internacional. $9^{\text {a }}$ edição, São Paulo: Editora Saraiva, 2008.

RAMÍREZ, Sergio García. El acceso de la víctima a la jurisdicción internacional sobre derechos humanos. In: Revista IIDH, vol. 32-33, 2000-2001, p.223-270.

. La jurisprudencia de la Corte Interamericana de Derechos Humanos en materia de reparaciones. In: Corte Interamericana de Derechos Humanos. La Corte Interamericana de Derechos Humanos: Un Cuarto de Siglo: 1979-2004. San José, Costa Rica, 2005, p. 185.

RANCIÈRE, Jacques. O princípio de insegurança. In: Mais! Folha de São Paulo, domingo, 21 de setembro de 2003.

SCHILLING, Flávia; CASTANHO E OLIVEIRA, Isaura de Mello; PAVES, Graziela Acquaviva (orgs.) Reflexões sobre justiça e violência: o atendimento a familiares de vítimas de crimes fatais. São Paulo: EDUC, Imprensa Oficial do Estado, 2002.

SILVA, Tadeu A. Dix. Globalização e Direito Penal brasileiro: acomodação ou indiferença? In: Revista Brasileira de Ciências Criminais $\mathrm{n}^{\circ}$. 23, ano 6, julhosetembro/1998, p.81-96.

SOUZA, Regina Maria de; GALLO, Silvio. Por que matamos o barbeiro? Reflexões preliminares sobre a paradoxal exclusão do outro. Educação \& Sociedade, ano XXIII, n ${ }^{\circ}$ 79, Agosto/2002.

SOUSA SANTOS, Boaventura. Pela Mão de Alice: o social e o político na pósmodernidade. $9^{\mathrm{a}}$ ed., São Paulo: Cortez Editora, 2003. 
. Da ciência moderna ao novo senso comum. In: $A$ crítica da razão indolente: contra o desperdício da experiência. Para um novo senso comum: a ciência, o direito e a política na transição paradigmática. $4^{\mathrm{a}}$ ed., São Paulo: Cortez Editora, 2002, p. 55-117.

. Uma cartografia simbólica das representações sociais. In: $A$ crítica da razão indolente: contra o desperdício da experiência. Para um novo senso comum: a ciência, o direito e a política na transição paradigmática. $4^{\mathrm{a}}$ ed., São Paulo: Cortez Editora, 2002, p.197-224.

. Introdução: para ampliar o cânone do reconhecimento, da diferença e da igualdade. In: Reconhecer para Libertar: os caminhos do cosmopolitismo multicultural. Rio de Janeiro: Civilização Brasileira, 2003, p.25-68.

. Por um Concepção Multicultural de Direitos Humanos. In:

Reconhecer para Libertar: os caminhos do cosmopolitismo multicultural. Rio de Janeiro: Civilização Brasileira, 2003, p. 427-461.

. As ruínas emergentes da modernidade e a pós-modernidade. Entrevista, Plural, Sociologia-USP, São Paulo, 1996, p. 135-152.

TINTA, Mónica Feria. La víctima ante la Corte Interamericana de Derechos Humanos a 25 años de su funcionamiento. In: Revista IIDH, vol. 43, 2006, p.159-203.

TPI (Tribunal Penal Internacional). Decisão da Câmara de Questões Preliminares I, de 17 de janeiro de 2006, referente à situação da República Democrática do Congo (ICC-01/04101-tEN.corr). Disponível em: < http://www.icc-cpi.int/library/cases/ICC-01-04101_tEnglish-Corr.pdf $>$. Acesso em 10 de agosto de 2007.

. Decisão de 10 de agosto de 2007, do juiz singular Mauro Politi, designado pela Câmara de Questões Preliminares II, referente à situação de Uganda (ICC-02/04-101). Disponível em: <http://www.icc-cpi.int/library/cases/ICC-02-04-101_English.pdf>. Acesso em 25 de agosto de 2007.

TODOROV, Tzvetan. O homem desenraizado. Rio de Janeiro: Record, 1999. Ascensão do homem público. In: Mais! Folha de São Paulo, domingo, 18/03/2001, p. 5-10.

TURRA, Nilda. Sistema Nacional de Atendimento e Assistência a Vítimas da Violência. Documento da Gerência de Assistência a Vítimas e a testemunhas ameaçadas, da Secretaria do Estado de Direitos Humanos/Ministério da Justiça, apresentado no Seminário “Integração das ações: um serviço às vítimas da violência”, em julho de 2002. 
UNDP. Human Rights Development Report 2004. Disponível em: www.undp.org/reports/global/2004/pdf/hdr04_HDI.pdf (acesso em: 02/08/2004).

UNICEF. The State of the World's Children 2007: Women and Children, the double dividend of gender equality. New York, 2006. Disponível em: http://www.unicef.org (acesso em 14/01/08)

Vidas Nuas, mortes banais: os homicídios em São Paulo através da fala de suas vítimas indiretas. Caderno de Resultados de Pesquisa realizada em parceria da Pontifícia Universidade Católica, Centro de Referência e Apoio à Vítima e Secretaria da Justiça e Defesa da Cidadania do Estado de São Paulo, 2003.

VIEIRA, Oscar Vilhena. A gramática dos direitos humanos. Revista do ILANUD $n^{o}$. 17, São Paulo, 2001, p.23-46.

WACQUANT, Löic. Os condenados da cidade: estudos sobre marginalidade avançada. Rio de Janeiro: Revan; FASE, 2001, p.7-42. As prisões da miséria. Rio de Janeiro: Jorge Zahar Editor, p.77-119.

Sites:

Alto Comissariado das Nações Unidas para os Direitos Humanos - Office of the High Commissioner for Human Rights. Disponível em: http://www.ohchr.org Comissão Interamericana de Direitos Humanos. Disponível em: http://www.cidh.org Comunidade Segura. Redes de idéias e práticas em Segurança Cidadã. Disponível em: http://www.comunidadesegura.org

Corte Interamericana de Direitos Humanos. Disponível em: http://www.corteidh.or.cr ONU - Organização das Nações Unidas. Disponível em: http://www.un.org Senado Federal. Disponível em: http://www.senado.gov.br Tribunal Penal Internacional - International Criminal Court. Disponível em: http://www.icc-cpi.int/ 


\section{ANEXO A - Termo de consentimento livre e esclarecido}

$\mathrm{Eu}$, , RG

concordo em participar, como voluntário (a), do projeto de pesquisa intitulado "A efetivação dos direitos humanos: o desafio do direito no atendimento interdisciplinar a vítimas de violência", que tem como pesquisadora responsável Akemi Kamimura, sob orientação de profa. Dra. Flávia Schilling, no Programa de Pós-Graduação da Faculdade de Direito da Universidade de São Paulo, que tem por objetivo estudar os desafios do atendimento interdisciplinar a vítimas de violência e a efetivação dos direitos humanos.

Estou ciente de que minha participação consistirá em participar de entrevista que será gravada.

Estou ciente que este estudo possui finalidade de pesquisa acadêmica, que os dados obtidos serão divulgados seguindo as diretrizes éticas da pesquisa, com a garantia de confidencialidade e sigilo, preservação do anonimato dos participantes, assegurando, assim sua privacidade.

Estou ciente que posso abandonar a minha participação na pesquisa quando quiser e que não receberei nenhum pagamento por esta participação.

Assinatura

Local e data. 


\section{ANEXO B - Questionário}

Perfil dos técnicos/ coordenadores dos projetos:

1. dados pessoais:

Nome

sexo: $(\mathrm{M})(\mathrm{F}) \quad$ idade:

- formação:

- $\quad$ estado civil:

- filhos?

- Estuda atualmente?

2. dados profissionais

- Quantos anos de formado?

- Conte sua trajetória profissional:

- Há quantos anos trabalha na organização?

- Como foi seu ingresso neste trabalho?

- Qual foi a motivação?

- Qual é a sua função/ atividade principal? Descreva um pouco como é seu dia-adia:

- Liste alguns fatores que fazem com que vc se sinta satisfeita(o) com seu trabalho: 


\title{
ANEXO C - Roteiro de entrevista
}

\author{
Bloco I- Vítimas
}

- Relate como é o atendimento do Centro.

- Relate seu papel neste atendimento

- Qual é o perfil das pessoas que procuram o Centro?

- Quais são as principais demandas?

- Como chegaram ao Centro? (quem informou sobre o trabalho?)

- Como é lidar com vítimas de violência?

- Quais são as principais dificuldades no atendimento?

- Quais são as principais dificuldades no trabalho?

- Há cursos/ apoio terapêutico/ suporte para os técnicos?

- Como define "vítima"?

\section{Bloco II- Direitos Humanos}

- Considera que este é um trabalho de proteção aos direitos humanos?

- Há uma explicitação deste trabalho como sendo de defesa dos direitos humanos para as vítimas, nos documentos, nas discussões, nas formações?

- Considera relevante esta explicitação?

Bloco III- interdisciplinaridade

- Quais são as áreas de atendimento?

- considera relevante - para a vítima - a existência de um diálogo entre os técnicos com diferentes formações?

- Como se dá a relação com os profissionais de outras áreas?

- Que papel cabe ao direito neste atendimento?

- Há momentos de discussão coletiva em que são traçados os contornos do atendimento buscando a interdisciplinaridade?

- O atendimento é multidisciplinar, interdisciplinar ou transdisciplinar?

Bloco IV- caso: Conte um caso que você considere exemplar.

Bloco V - principais desafios 


\section{ANEXO D - Relação de entrevistas realizadas}

Centro de Referência às Vítimas de Violência (CNRVV)

E1

E2

E3

E4

E5

E6

E7

E8

Centro de Referência e Apoio à Vítima (CRAVI)

E9

E10

E11

E12

E13

E14

E15

AJ1

$\mathrm{AJ} 2$

Advogados com experiência no atendimento interdisciplinar a vítimas de violência $\mathrm{AJ} 3$

AJ4 